2020 № 4(46)

в центральной России

В журнале публикуются статьи проблемного и научно-практического характера, представляющие собой результаты завершённых исследований, обладающие новизной и представляющие интерес для широкого круга читателей журнала

\title{
ФГБНУ ВНИИТиН
}




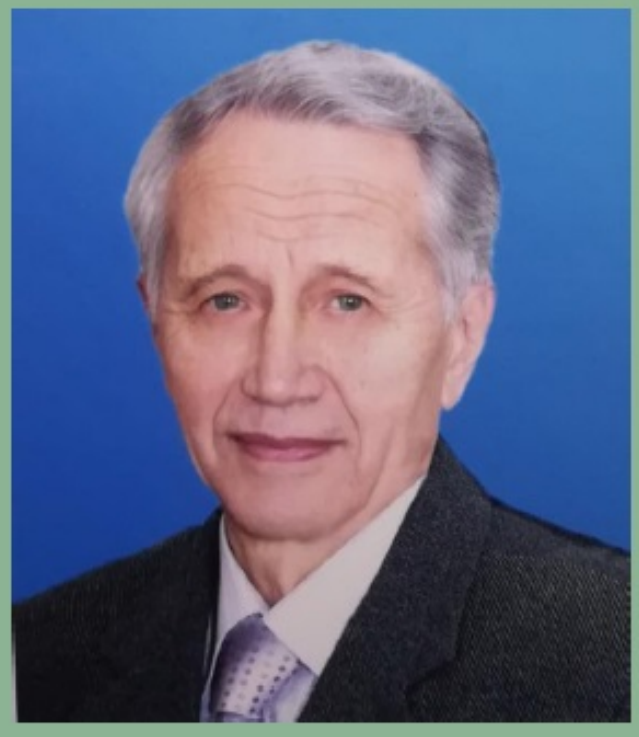

Анатолию Михайловичу Нувалову 80 лет!

Шувалов А.М. - доктор технических наук, профессор работал в должности заведующего лабораторией использования альтернативных источников энергии взамен жидкого топлива с 1973 по 2019 гг. сначала в филиале ВИЭСХ, затем во ВНИИТиНе. В 1992 г. организовал ООО Научно производственное предприятие «Альтернатива» и по 2010 г. был директором этого предприятия. С 2000 по 2008 гг. являлся членом диссертационного совета по защите докторских и кандидатских диссертаций и более 10 лет был председателем государственной аттестационной комиссии по защите дипломов инженеров-электриков в Тамбовском государственном техническом университете. С 2002 г. по настоящее время - член диссертационного совета в Мичуринском государственном аграрном университете. Обладатель гранта Президента России. На Всероссийских конкурсах за научные разработки присуждались 1-я, 2-я, 3-я премии. Разработанные совместно с сотрудниками лаборатории энергетические установки на ВДНХ СССР оценены золотой, тремя серебряными медалями и медалью Всероссийского выставочного центра (ВВЦ). Награжден медалями «За доблестный труд», «Ветеран труда».

\section{Дорогой Анатолий Михайлович!}

Коллектив ФГБНУ ВНИИТиН сердечно поздравляет Вас со славным юбилеем! Ваш большой и замечательный трудовой путь с начала до конца связан с нашим институтом. Все свои душевные и творческие силы Вы посвятили развитию приоритетных направлений сельскохозяйственной науки, подготовке высококвалифицированных кадров. Вы сами являетесь ярким примером успешности профессионального и личностного развития. Вами опубликовано более 350 статей, изданы две книги, справочник энергетика и 18 брошюр, получено 39 патентов. Все это стало значимыми достижениями института. Под Вашим руководством подготовлено 9 кандидатов технических наук. Присущая Вам активная жизненная позиция, научный опыт, принципиальность и ответственность снискали Вам глубокое уважение у коллег и в научном сообществе.

От всей души поздравляем Вас, дорогой Анатолий Михайлович, с 80 летием! Желаем Вам крепкого здоровья на долгие годы, счастья, благополучия Вам и Вашим близким, новых творческих успехов! Пусть всегда радуют людей Ваши инициативность, энергичность и жизнелюбие, неиссякаемая энергия в достижении поставленных целей и новых свершений на благо Великой России! 


\section{«НАУКА В ЦЕНТРАЛЬНОЙ РОССИИ»}

Научно-производственный периодический журнал Включен в Перечень рецензируемых научных изданий, в которых должны быть опубликованы основные научные
результаты диссертаций на соискание ученой степени кандидата наук, на соискание ученой степени доктора наук, результаты диссертаций на соискание ученой степени кандидата наук, на сой
в международную базу данных Agris № 4 (46), 2020 г.

Основанв 2012 г.

Выходит 6 раз в год
It is based in 2012.

There are 6 times a year

\section{Учредитель и издатель журнала: \\ Федеральное государственное бюджетное научное учреждение \\ Всероссийский научно-исследовательский институт использования техники и нефтепродуктов в сельском хозяйстве (ФГБНУ ВНИИТИН) \\ РЕДАКЦИОННЫЙ СОВЕТ \\ НАУЧНО-ПРОИЗВОДСТВЕННОГО ПЕРИОДИЧЕСКОГО ЖУРНАЛА \\ «НАУКА В ЦЕНТРАЛЬНОЙ РОССИИ»}

АКИМОВ Михаил Юрьевич - директор ФГБНУ «Федеральный научный центр им. И.В. Мичурина», кандидат сельскохозяйственных наук

ГУЛЕВСКИЙ Вячеслав Анатольевич - проректор по научной работе ФГБОУ ВО «Воронежский государственный аграрный университет имени императора Петра І», доктор технических наук, доцент

ДЕРКАНОСОВА Наталья Митрофановна - проректор по учебной работе, ФГБОУ ВО «Воронежский государственный аграрный университет имени императора Петра І», доктор технических наук, профессор

ЖАЛНИН Эдуард Викторович - заведующий отделом технологий и оборудования для зерновых, зернобобовых и масличных культур ФГБНУ «Федеральный научный агроинженерный центр ВИМ», доктор технических наук, профессор ЗАВРАЖНОВ Анатолий Иванович - главный научный сотрудник ФГБОУ ВО «Мичуринский государственный аграрный университет», академик РАН, доктор технических наук, профессор, заслуженный деятель науки и техники РФ КАЗАКЕВИЧ Пётр Петрович - заместитель председателя президиума Национальной академии наук Республики Беларусь, член-корреспондент национальной академии наук Беларуси, доктор технических наук, профессор, иностранный член РАН

КОСТЮЧЕНКОВ Николай Васильевич - профессор кафедры «Аграрная техника и технологии» Казахского агротехнического университета им. С. Сейфуллина, действительный член Академии сельскохозяйственных наук Республики Казахстан, доктор технических наук, профессор

КРАСНЯНСКИЙ Михаил Николаевич - доктор технических наук, профессор, профессор РАН, ректор ФГБОУ ВО «Тамбовский государственный технический университет»

ЛАЧУГА Юрий Федорович - академик-секретарь Отделения сельскохозяйственных наук РАН, академик РАН, доктор технических наук, профессор

НИКИТИН Александр Валерьевич - председатель попечительского совета Мичуринского государственного аграрного университета, профессор кафедры управления и делового администрирования ФГБОУ ВО «Мичуринский государственный аграрный университет», доктор экономических наук, профессор.

ОСТРИКОВ Валерий Васильевич - председатель редакционного совета, главный редактор журнала, врио директора ФГБНУ ВНИИТиН, доктор технических наук

ЦОЙ Юрий Алексеевич - генеральный директор научно-производственного предприятия «Фемакс» (Москва), членкорреспондент РАН, доктор технических наук, профессор, заслуженный деятель науки и техники Российской Федерации BIANCO Vincenzo - Department of mechanical, energy, management end transportation engineering, Univercity of Genoa, Italy, Ph.D., Associate Professor

VIGDOROVITSCH Michael - Geschäftsführer ANGARA GmbH, Düsseldorf, Deutschland, doktor fiziko-matematicheskih nauk (Doktor der physikalischen und mathematischen Wissenschaften) Frumkin Institute of Physical Chemistry and Electrochemistry Russian Academy of Sciences

\section{Редакция}

Журнал «Наука в Центральной России Science in the central Russia»

Учредитель: Федеральное государственное бюджетное научное учреждение «Всероссийский научно-исследовательский институт использования техники и нефтепродуктов в сельском хозяйстве»

Главный редактор: Остриков В.В; заместители главного редактора: Корнев А.Ю., Сазонов С.Н.

№ 4 (46). Дата выхода в свет 31.08.2020. Тираж - 100 экз. Свободная цена. Подписной индекс 25196.

Адрес редакции и издателя: 392022, Тамбовская область, г. Тамбов, пер. Ново-Рубежный, д. 28, тел. 8(4752) 44-64-14; e-mail: viitin@mail.ru

Отпечатано в типографии «Студия печати Галины Золотовой». Адрес типографии: 392032, Тамбовская область, г. Тамбов, ул. Кленовая, д. 24. e-mail: studiapechati@bk.ru.

Печатное издание журнал «Наука в Центральной России» зарегистрировано в Федеральной службе по надзору в сфере связи, информационных технологий и массовых коммуникаций (Роскомнадзор). Свидетельство о регистрации СМИ ПИ № ФС 77 - 66036 от 10.06 .2016 г. 


\section{«НАУКА В ЦЕНТРАЛЬНОЙ РОССИИ»} Включен в Перечень рецензируемых научных изданий, в которых должны быть опубликованы основные научные результаты диссертаций на соискание ученой степени кандидата наук, на соискание ученой степени доктора наук, в международную базу данных Agris

$$
\text { № } 4 \text { (46), } 2020 \text { г. }
$$

Основанв 2012 г.

It is based in 2012.

Выходит 6 раз в год

There are 6 times a year

\section{РЕДАКЦИОННАЯ КОЛЛЕГИЯ \\ НАУЧНО-ПРОИЗВОДСТВЕННОГО ПЕРИОДИЧЕСКОГО ЖУРНАЛА \\ «НАУКА В ЦЕНТРАЛЬНОЙ РОССИИ»}

\subsubsection{1 Технологии и средства механизации сельского хозяйства}

АНАШКИН Александр Витальевич - заведующий лабораторией управления качеством технологических процессов в сельском хозяйстве ФГБНУ ВНИИТиН, кандидат технических наук

ВЕДИЩЕВ Сергей Михайлович - заведующий кафедрой «Агроинженерия» ФГБОУ ВО «Тамбовский государственный технический университет», кандидат технических наук, доцент

ДОРОВСКИХ Владимир Иванович - заведующий лабораторией управления качеством технологических процессов в животноводстве ФГБНУ ВНИИТиН, кандидат технических наук, доцент

ЕРОХИН Геннадий Николаевич - заведующий лабораторией эксплуатационных требований к сельскохозяйственной технике ФГБНУ ВНИИТиН, кандидат технических наук

КАПУСТИН Василий Петрович - профессор кафедры «Агроинженерия» ФГБОУ ВО «Тамбовский государственный технический университет», доктор технических наук, профессор

ОЖЕРЕЛЬЕВ Виктор Николаевич - профессор кафедры «Технические системы в агробизнесе, природообустройстве и дорожном строительстве» ФГБОУ ВО «Брянский государственный аграрный университет», доктор сельскохозяйственных наук, профессор

ОРОБИНСКИЙ Владимир Иванович - декан агроинженерного факультета, заведующий кафедрой «Сельскохозяйственные машины, тракторы и автомобили» ФГБОУ ВО «Воронежский государственный аграрный университет имени императора Петра І», доктор сельскохозяйственных наук, профессор

РОДИОНОВ Юрий Викторович - заведующий кафедрой «Техническая механика и детали машин» ФГБОУ ВО «Тамбовский государственный технический университет», доктор технических наук, профессор

ТИШАНИНОВ Николай Петрович - главный научный сотрудник лаборатории управления качеством технологических процессов в сельском хозяйстве ФГБНУ ВНИИТиН, доктор технических наук, профессор

ШАЦКИЙ Владимир Павлович - заведующий кафедрой «Математики и физики» ФГБОУ ВО «Воронежский государственный аграрный университет имени императора Петра I», доктор технических наук, профессор

ШВАРЦ Анатолий Адольфович - профессор кафедры «Стандартизации и оборудования перерабатывающих производств» ФГБОУ ВО «Курская государственная сельскохозяйственная академия имени И.И. Иванова», доктор сельскохозяйственных наук, профессор.

\subsubsection{3 Технологии и средства технического обслуживания в сельском хозяйстве}

АФОНИЧЕВ Дмитрий Николаевич - заведующий кафедрой «Электротехники и автоматики» ФГБОУ ВО «Воронежский государственный аграрный университет имени императора Петра I», доктор технических наук, профессор

БАЛАБАНОВ Виктор Иванович - заведующий кафедрой «Мелиоративных и строительных машин» ФГБОУ ВО «Российский государственный аграрный университет - МСХА имени К.А. Тимирязева», доктор технических наук, профессор.

ВАСИЛЕНКО Владимир Васильевич - профессор кафедры «Сельскохозяйственные машины, тракторы и автомобили» ФГБОУ ВО «Воронежский государственный аграрный университет имени императора Петра І», доктор технических наук, профессор КНЯЗЕВА Лариса Геннадиевна - ученый секретарь ФГБНУ ВНИИТиН, доктор химических наук, доцент КОРНЕВ Алексей Юрьевич - заместитель главного редактора журнала, заместитель директора ФГБНУ ВНИИТиН по научной работе, кандидат технических наук

МАНАЕНКОВ Константин Алексеевич - директор Инженерного института ФГБОУ ВО «Мичуринский государственный аграрный университет», доктор технических наук, профессор

МАШКОВ Алексей Николаевич - ведущий научный сотрудник лаборатории альтернативных источников энергии взамен жидкого топлив ФГБНУ ВНИИТиН, кандидат технических наук

НАГОРНОВ Станислав Александрович - главный научный сотрудник лаборатории организации нефтехозяйств и экономного расходования нефтепродуктов ФГБНУ ВНИИТиН, доктор технических наук, профессор

ПЕТРАШЕВ Александр Иванович - заведующий лабораторией организации хранения и защиты техники от коррозии ФГБНУ ВНИИТиН, доктор технических наук

САЗОНОВ Сергей Николаевич - заместитель главного редактора журнала, главный научный сотрудник лаборатории использования смазочных материалов и отработанных нефтепродуктов ФГБНУ ВНИИТиН, доктор технических наук, профессор САФОНОВ Валентин Владимирович - заведующий кафедрой «Технический сервис и технология конструкционных материалов» ФГБОУ ВО «Саратовский государственный аграрный университет им. Н.В.Вавилова», доктор технических наук, профессор

ШУВАЛОВ Анатолий Михайлович - заведующий лабораторией использования альтернативных источников энергии ФГБНУ ВНИИТиН, доктор технических наук, профессор 


\section{ОГЛАВЛЕНИЕ}

Тищанинов Н.П.

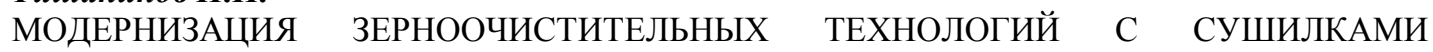
КАРУСЕЛЬНОГО ТИПА

Тищанинов К.Н., Тищанинов Н.П.

ОЦЕНКА ПРЕИМУЩЕСТВА НАКЛОННОГО ИСПОЛНЕНИЯ ЩЕЛЕВОЙ СТЕНКИ ЖАЛЮЗИЙНОГО ДЕЛИТЕЛЯ ПОТОКА ЗЕРНА

Степанов К.А., Иванов М.В., Крюков М.Л.

ИССЛЕДОВАНИЕ ТЕХНОЛОГИЧЕСКОГО ПРОЦЕССА КОНТЕЙНЕРНОЙ ЗАГОТОВКИ

СЕЛЕКЦИОННОГО ЗЕРНА В УСЛОВИЯХ ПЕРВИЧНОГО РАЗМНОЖЕНИЯ

Бочкарев А.С., Ларюшин Н.П., Кухарев О.Н.

РЕЗУЛЬТАТЫ ЭКСПЕРИМЕНТАЛЬНЫХ ИССЛЕДОВАНИЙ ВЫСАЖИВАЮЩЕГО

АППАРАТА МИНИ КАРТОФЕЛЕСАЖАЛКИ

Гаджиев П.И., Рамазанова Г.Г., Манаенков К.А.

ПОВЫШЕНИЕ ЭФФЕКТИВНОСТИ ОБРАБОТКИ ПОЧВЫ ДЛЯ КОМБАЙНОВОЙ УБОРКИ

КАРТОФЕЛЯ

Башкирев А.П., Швари А.А., Иванов Н.А.

ОСОБЕННОСТИ РАБОТЫ КАРТОФЕЛЕСАЖАЛОК

Башкирев А.П., Швари А.А., Иванов Н.А.

РЕЗУЛЬТАТЫ ИССЛЕДОВАНИЙ ЭКСПЕРИМЕНТАЛЬНОГО СОШНИКА

КАРТОФЕЛЕСАЖАЛКИ

Симонов Г.А., Никифоров В.Е., Филиппова О.Б.

ПРЕИМУЩЕСТВА РОБОТОВ ПЕРЕД ТРАДИЦИОННОЙ ТЕХНОЛОГИЕЙ ДОЕНИЯ КОРОВ

Шувалов А.М., Машков А.Н., Чернов Д.С.

$$
\text { ОБОСНОВАНИЕ ПРИНЦИПА }
$$

САМОРЕГУЛИРОВАНИЯ МОЩНОСТИ

КОРМОВАРОЧНОГО КОТЛА НА ГАЗОВОМ ТОПЛИВЕ.

Князева Л. Г., Дорохов А.В., Курьято Н.А.

ОЦЕНКА РАСХОДА CORTEC VPCI-368 И CORTEC VPCI-369 ДЛЯ

ПРОТИВОКОРРОЗИОННОЙ ЗАЩИТЫ СЕЛЬСКОХОЗЯЙСТВЕННОЙ ТЕХНИКИ ОТ

АТМОСФЕРНОЙ КОРРОЗИИ...

ЗАЩИТЫ СЕЛЬСКОХОЗЯЙСТВЕННОЙ ТЕХНИКИ ОТ

Ли Р.И., Киба М.Р., Быконя А.Н.

ИССЛЕДОВАНИЕ ТРИБОЛОГИЧЕСКИХ ПАРАМЕТРОВ И КОНТАКТНЫХ

НАПРЯЖЕНИЙ В ПОДШИПНИКАХ КАЧЕНИЯ АВТОМОБИЛЕЙ.

Остриков В.В., Vigdorowitsch М., Жерновников Д.Н., Кошелев А.В.

ТЕОРЕТИЧЕСКИЕ АСПЕКТЫ ОЦЕНКИ ЭФФЕКТИВНОСТИ ПРОМЫВКИ СИСТЕМЫ

СМАЗКИ ДВС ОТ ЗАГРЯЗНЕНИЙ

Нагорнов С.А., Корнев А.Ю., Романцова С.В.

ПУТИ ЭКОНОМНОГО РАСХОДОВАНИЯ СВЕТЛЫХ НЕФТЕПРОДУКТОВ В СЕЛЬСКОМ ХОЗЯЙСТВЕ

Нагорнов С.А., Корнев А.Ю., Романцова С.В.

ОПТИМАЛЬНОЕ УПРАВЛЕНИЕ ПРОЦЕССОМ ПЕРЕЭТЕРИФИКАЦИИ ЖИРОВ

РАСТИТЕЛЬНОГО И ЖИВОТНОГО ПРОИСХОЖДЕНИЯ .............................................................. 98 


\section{CONTENTS}

Tishaninov $N$. MODERNIZATION OF GRAIN-CLEANING TECHNOLOGIES WITH CAROUSEL TYPE DRYERS

Tishaninov K., Tishaninov $N$.

EVALUATING THE ADVANTAGES OF SLOPING SLOTTED WALL DESIGN OF A LOUVERED GRAIN FLOW DIVIDER

Stepanov K., Ivanov M., Kryukov M.

RESEARCH OF TECHNOLOGICAL PROCESS OF CONTAINER PREPARATION OF SELECTION GRAIN IN CONDITIONS OF PRIMARY REPRODUCTION

Bochkarev A., Laryushin N., Kuharev $O$.

EXPERIMENTAL RESEARCH RESULTS PLANTING APPARATUS AT MINI POTATO PLANTER

Gadzhiyev P., Ramazanova G., Manayenkov K.

IMPROVING THE EFFICIENCY OF TILLING THE SOIL FOR COMBINE HARVESTING POTATOES

Bashkirev A., Shvartz, A., Ivanov N.

FEATURES OF POTATO PLANTER WORK

Bashkirev A., Shvartz, A., Ivanov N.

THE RESULTS OF STUDIES OF EXPERIMENTAL SEED POTATO PLANTER.

Simonov G., Nikivorov $V$. , Filippova $\boldsymbol{O}$.

ADVANTAGES OF ROBOTS OVER TRADITIONAL COW MILKING TECHNOLOGY 54

Shuvalov A., Mashkov A., Chernov D.

SUBSTANTIATION OF THE PRINCIPLE OF SELF-REGULATION OF THE POWER OF THE FEEDING BOILER ON GAS FUEL

Knyazeva L., Dorokhov A., Kuryato N.

EVALUATION OF CONSUMPTION CORTEC VPCI-368 AND CORTEC VPCI-369 FOR ANTICORROSION PROTECTION OF AGRICULTURAL EQUIPMENT FROM ATMOSPHERIC CORROSION

Lee R., Kiba M., Bykonya A.

RESEARCH OF TRIBOLOGICAL PARAMETERS AND CONTACT STRESSES IN CAR ROLLING BEARINGS....

Ostrikov V., Vigdorowitsch M., Zhernovnikov D., Koshelev A.

THEORETICAL ASPECTS OF EVALUATING THE RINSING EFFICIENCY OF THE ICE

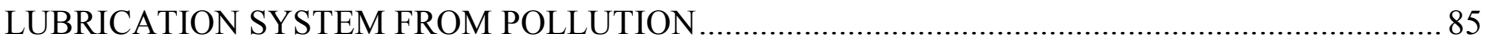

Nagornov S., Kornev A., Romantsova $S$.

WAYS OF ECONOMICAL CONSUMPTION OF LIGHT OIL PRODUCTS IN AGRICULTURE

Nagornov S., Kornev A., Romantsova S.

OPTIMAL CONTROL FOR THE PROCESS OF TRANSESTERIFICATION OF VEGETABLE AND ANIMAL FATS 
УДК 631.303

DOI: $10.35887 / 2305-2538-2020-4-5-11$

\title{
МОДЕРНИЗАЦИЯ ЗЕРНООЧИСТИТЕЛЬНЫХ ТЕХНОЛОГИЙ С СУШИЛКАМИ КАРУСЕЛЬНОГО ТИПА
}

\author{
${ }^{1}$ Тишанинов Николай Петрович \\ ${ }^{I}$ ФББНУ «Всероссийский научно-исследовательский институт \\ использования техники и нефтепродуктов в сельском хозяйстве»
}

\begin{abstract}
Реферат. Дан анализ уровня использования существующих зерноочистительных технологий по показателям качества прочессов и технологических потерь, которые достигают 17,5 \%. Установлены причины значительных технологических потерь, состоящие в снижении управляемости разноканальных технологий из-за отсутствия эффективных средств деления перевалочных потоков зерносмесей и их подачи на технологические каналь. Выявлено, что включение в зерноочистительную технологию сушилок карусельного типа, размещенных на нижних отметках, требует дополнительного перевалочного средства и увеличивает вариативность технологических реализащий до 4-х: загрузка сушилки исходным зерновым ворохом; сортировка подсушенного зернового вороха + дозагрузка сушилки; сортировка подсушенного зернового вороха без дозагрузки сушилки; сортировка исходного зернового вороха без его подсушки. Дано технико-экономическое обоснование двух вариантов модернизации технологий. Установлено, что вариант с больиим объемом монтажно-демонтажных работ с целью сокращчения одной нории является малоэффективным. В более предпочтительном варианте сохраняются оба перевалочных средства, которые оснащаются двухканальными авторегулируемыми делителями потока зерносмеси каскадного исполнения. Определено, что второй вариант модернизачии дешевле по капитальным вложениям в 1,5 раза в сравнении с первым. Кроме того делители каскадного типа в 1,5 - 1,7 раза меньше по технологической высоте относительно жалюзийных делителей, что создает запас углового размещеения зернопроводов в пространстве и обеспечивает повышение технологической надежности основного оборудования. Установлено расчетным путем, что сокращчение технологических потерь хотя бы на 1,5 \% за счет модернизации технологии подработки зерна позволяет окупить затраты на нее в первый год эксплуатации.
\end{abstract}

Ключевое слова: зерноочистительная технология, эффективность, качество, модернизация, управляемость, авторегулируемые делители, технологические потери.

\section{MODERNIZATION OF GRAIN-CLEANING TECHNOLOGIES WITH CAROUSEL TYPE DRYERS}

\section{${ }^{1}$ FSBSI “All-Russian Research Institute for Use of Machinery and Petroleum Products in Agriculture”"}

Abstract. The analysis of the level of use of existing grain cleaning technologies in terms of the quality of processes for cleaning grain mixtures and technological losses, which reach 17,5\%, is given. The reasons for significant technological losses, consisting in a decrease in the manageability of multichannel technologies due to the lack of effective means of dividing the transshipment flows of grain mixtures and their supply to the technological channels, are established. Revealed that the inclusion of grain dryers technology the carousel, placed on the bottom levels, requires additional transit funds and increases the variability of technological implementations to 4: boot dryer original grain pile; sorting dried grain heap + reheating of the dryer, sorting the dried grain piles without reloading the dryer, sorting the original grain heap without drying. A feasibility study of two options for technology modernization is given. It was found that the option with a large volume of installation and dismantling works in order to reduce one Noria is ineffective. In a more preferable variant, both transshipment facilities are preserved, which are equipped with two-channel auto-adjustable dividers of the flow of grain mixtures of cascading execution. It is determined that the second option of modernization is 1,5 times cheaper in terms of capital investment compared to the first one. In addition, cascade dividers are 
1,5 - 1,7 times smaller in terms of technological height relative to louver dividers, which creates a margin for angular placement of grain pipelines in space and provides an increase in the technological reliability of the main equipment. It is estimated that reducing technological losses by at least 1,5\% due to the modernization of the grain processing technology allows you to recoup the cost of it in the first year of operation.

Keywords: grain cleaning technology, efficiency, quality of modernization, manageability, autoadjustable dividers, technological losses.

Введение. Около двух миллиардов тонн зерна ежегодно производится в мировом аграрном секторе экономики и подвергается очистке от примесей перед хранением и переработкой. Сотни заводов производят зерноочистительные машины для решения этой задачи. Технологические традиции разделения зерносмесей по базовым признакам сохраняются на протяженной многих десятилетий, однако проблемы качества зерноочистительных технологий остаются нерешенными. Технологические потери при подработке зерна достигают 15 - 20 \%. В малоценных компонентах зерносмесей (фураже и отходах) после разделения содержится 25 - 67 \% зерновок основной культуры. Высока степень остаточной засоренности очищенного зерна относительно современных требований к его качеству. Технологические потери на заключительном этапе зернового производства пропорциональны объему непроизводительных затрат труда, ресурсов и потере соответствующей доли природной ренты. Основные причины сложившегося положения заключаются в отсутствии эффективных средств управления потоками зерна в многоканальных технологических процессах и научно-обоснованных регламентов настройки машин. В существующих зерноочистительных технологиях перевалочные операции реализуются в 1 или 2 канала, а очистительные (сепарирующие) операции - в 4 или 6 каналов. Поэтому перевалочные потоки нужно разделять на несколько равных технологических, что создает предпосылки последующей управляемости процессом и обеспечения его качества. Однако, используемые в производстве флажковые, призменные и тарельчатые делители не обеспечивают качество деления зерновых потоков - погрешность деления превышает 150 \%. Падающие потоки зерна меняют направление движения и геометрию сечения, что исключает их качественное деление указанными выше делителями. В этих условиях зерноочистительные технологии используются за границами экономической эффективности из-за высоких технологических потерь и ограничений технологической надежности. Из-за нерегламентированной подачи зерна в триерные блоки, например, перегружаемые ячеистые цилиндры поочередно забиваются и простаивают в состоянии технологического отказа. Около 90 \% триерных блоков по этой причине выведено из эксплуатации - ущерб по капитальным вложениям составляет многие десятки миллиардов рублей. Поэтому актуальность модернизации существующих зерноочистительных агрегатов на основе вновь созданных средств и научно-обоснованных регламентов управления технологическими процессами сомнений не вызывает.

Материалы и методы. В работе использованы аналитический и расчетно-конструктивный методы, материалы обследования сельскохозяйственных предприятий и результаты разработок.

Результаты и их обсуждение. В Центрально-Черноземном регионе сельские товаропроизводители включают в состав зерноочистительного комплекса сушилки карусельного типа. Это решение является обоснованным по климатическим условиям уборки зерновых культур, но усложняет управление технологическими процессами. При использовании сушилок технологический процесс реализуется по четырем составам операций: загрузка сушилки исходным зерновым ворохом; сортировка посушенного вороха + дозагрузка сушилки; сортировка подсушенного зернового вороха без дозагрузки сушилки; сортировка неподсушенного зернового вороха.

Обеспечить управление технологическим процессом с указанной выше вариативностью операций сложно даже при использовании двух перевалочных норий. При смене вариантов реализации технологии в некоторых предприятиях приходится даже пересоединять зернопроводы. Единственным средством управления процессом в этих случаях кроме шиберов норий является тарельчатый делитель, который используется по прямому назначению и в качестве переключателя. Он не обеспечивает качество деления потока зерна, что снижает эффективность процесса подработки зерна по производительности и качеству. 
В существующих технологиях одноручьевая нория обеспечивает процессы перевалки и распределения исходного зернового вороха с помощью тарельчатого делителя, а двухручьевая подачу подсушенного зернового вороха на решетные станы. Нами предлагается два варианта реализации технологического процесса: 1) использование одной двухручьевой нории с каскадным делителем в начале технологического процесса, когда нория загружается зерновым вороха из приемного бункера; 2) использование двух существующих норий с каскадными делителями.

Схема технологического процесса подработки зерна с использованием карусельной сушилки по 1-му варианту модернизации представлена на рисунке 1.

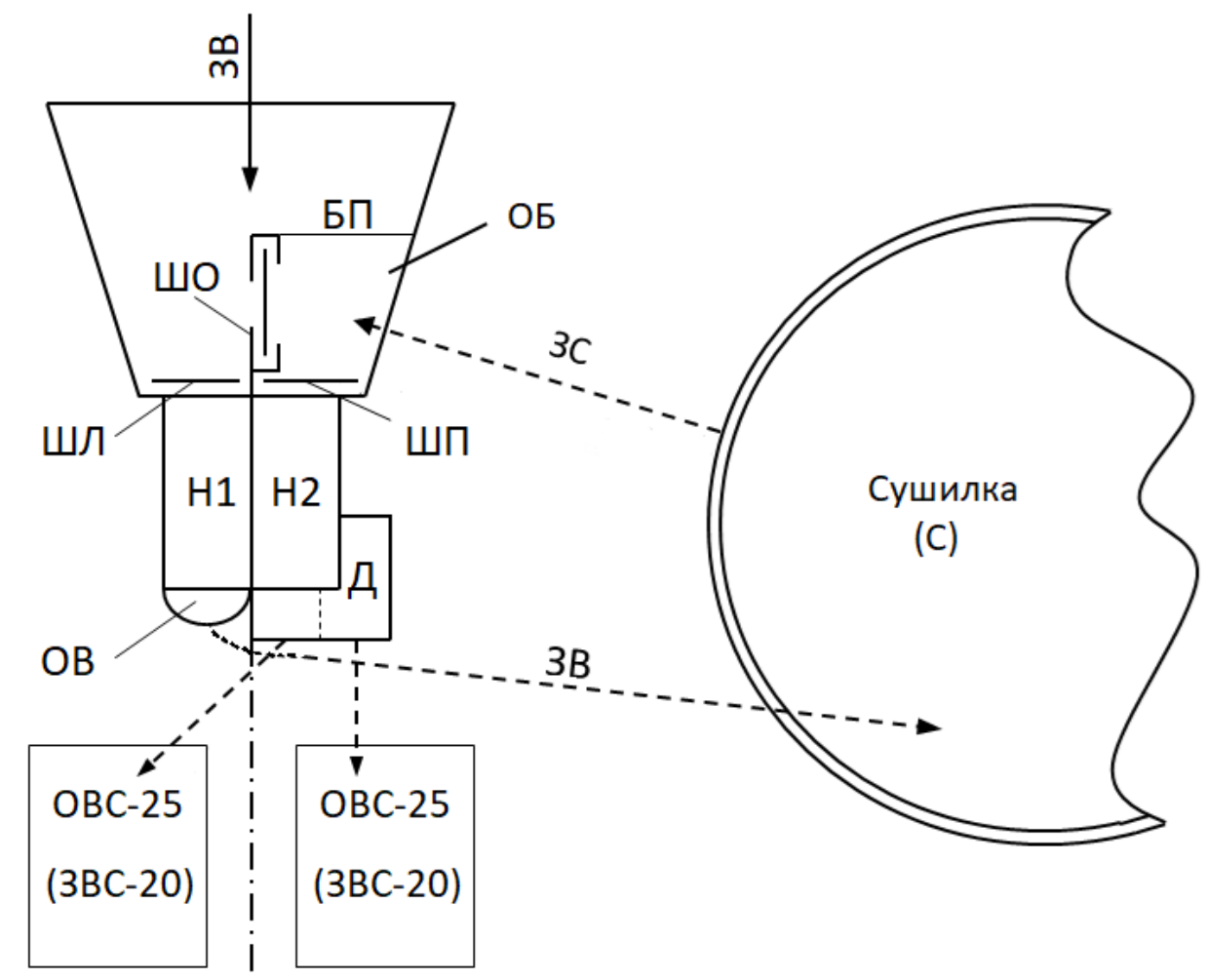

Рисунок 1 - Схема технологического процесса по 1-му варианту модернизации

Загрузка сушилки исходным зерновым ворохом (ЗВ) осуществляется при заполненном приемном бункере (БП) через открытый канал нории (Н1) посредством левого шибера (ШЛ) и отвода (OB).

Второй состав операций, обеспечивающий сортировку сухого зерна (ЗС) и одновременную дозагрузку сушилку (C), осуществляется следующим образом. Сухое зерно (ЗС) из сушилки самотеком по зернопроводу поступает в отсек бункера (ОБ) с закрытым шибером отсека (ШО). Далее через открытый шибер (ШП) канала нории (Н2) сухое зерно подается в каскадный делитель, а из него - на зерноочистительные машины ОВС-25 или ЗВС-20.

Третий состав операций, обеспечивающий сортировку сухого зерна, реализуется при закрытых шибера (ШЛ, ШО) и открытом ШП, через который сухое зерно каналом нории (Н2) подается в каскадный делитель (Д), а из делителя - в зерноочистительные машины.

Четвертый вариант технологии предназначен для сортировки зернового вороха (3В) бед подсушки, когда ЗВ из приемного бункера (БП) через открытые шибера (ШО, ШП) поступает в канал нории (Н2). При этом шибер (ШЛ) закрыт. Далее ЗВ подается в каскадный делитель, а из него - в зерноочистительные машины.

Bсе четыре варианта реализации технологии при 1-ом варианте модернизации можно представить соответствующими им последовательностями прохождения составных частей машинной технологии и состояниями рабочей среды: 
1) $3 \mathrm{~B} \rightarrow$ БП $\rightarrow$ ШЛ $\rightarrow \mathrm{H} 1 \rightarrow \mathrm{OB} \rightarrow \mathrm{C}$;

2) $3 \mathrm{C} \rightarrow \mathrm{C} \rightarrow$ ОБ $\rightarrow$ ШП $\rightarrow \mathrm{H} 2 \rightarrow$ Д $\rightarrow$ ОВC-25 (3ВС-20) + операции по п.1;

3) $3 \mathrm{C} \rightarrow \mathrm{C} \rightarrow$ ОБ $\rightarrow$ ШП $\rightarrow \mathrm{H} 2 \rightarrow$ Д $\rightarrow$ OBC-25 (3ВC-20);

4) $3 \mathrm{~B} \rightarrow$ ШО $\rightarrow$ ОБ $\rightarrow$ ШП $\rightarrow \mathrm{H} 2 \rightarrow$ Д $\rightarrow$ OBC-25 (3ВC-20).

Преимущество 1-го варианта модернизации заключается в сокращении числа используемых норий - с двух в существующем варианте до одной. Однако, при этом необходимо демонтировать две нории и смонтировать двухручьевую на месте размещения одноручьевой. Стоимость монтажно-демонтажных работ оценивается $\approx 300$ тыс. руб. Кроме того необходимо реконструировать приемный бункер и оборудовать функционально самостоятельный отсек (ОБ). Причем необходимость обеспечения технологической надежности подачи зернового вороха в канал $(\mathrm{H} 2)$ через ШО и ШП требует понижения размещения башмака нории относительно прежней отметки с тем, чтобы увеличить уклон днища в отсеке (ОБ). Размещение зернопровода от сушилки (С) к отсеку (ОБ) также требует увеличения уклона.

Эти работы требуют дополнительных затрат в объеме $\approx 120$ тыс. руб., а в сумме $\approx 420$ тыс. руб. Если оценивать выигрыш от первого варианта модернизации сокращением эксплуатационных затрат на использование сокращаемой нории, то они не сопоставимы с затратами на реконструкцию. Основная статья экономии - сокращение затрат на электроэнергию, но при годовом объеме работ зерноочистительного агрегата в 3000 - 4000 т, производительности около 20 т/ч и установленной (на нории) мощности электропривода 4 кВт возможная экономия составит $4-5,5$ тыс. руб.

Поэтому в более предпочтительном варианте модернизации не следует демонтировать существующие нории. Основное внимание следует уделить качеству управления технологическим процессом, которое может быть обеспечено установкой каскадного делителя на каждой нории, рисунок 2. В этом варианте модернизации зерноочистительно-сушильной технологии первая технологическая задача по загрузке сушилки исходным зерновым ворохом решается аналогичным способом. Зерновой ворох (ЗВ) из приемного бункера (БП1) при открытом шибере (Ш1) поступает в башмак нории (H1) и подается через переключатель (П) в зернопровод к сушилке (С).

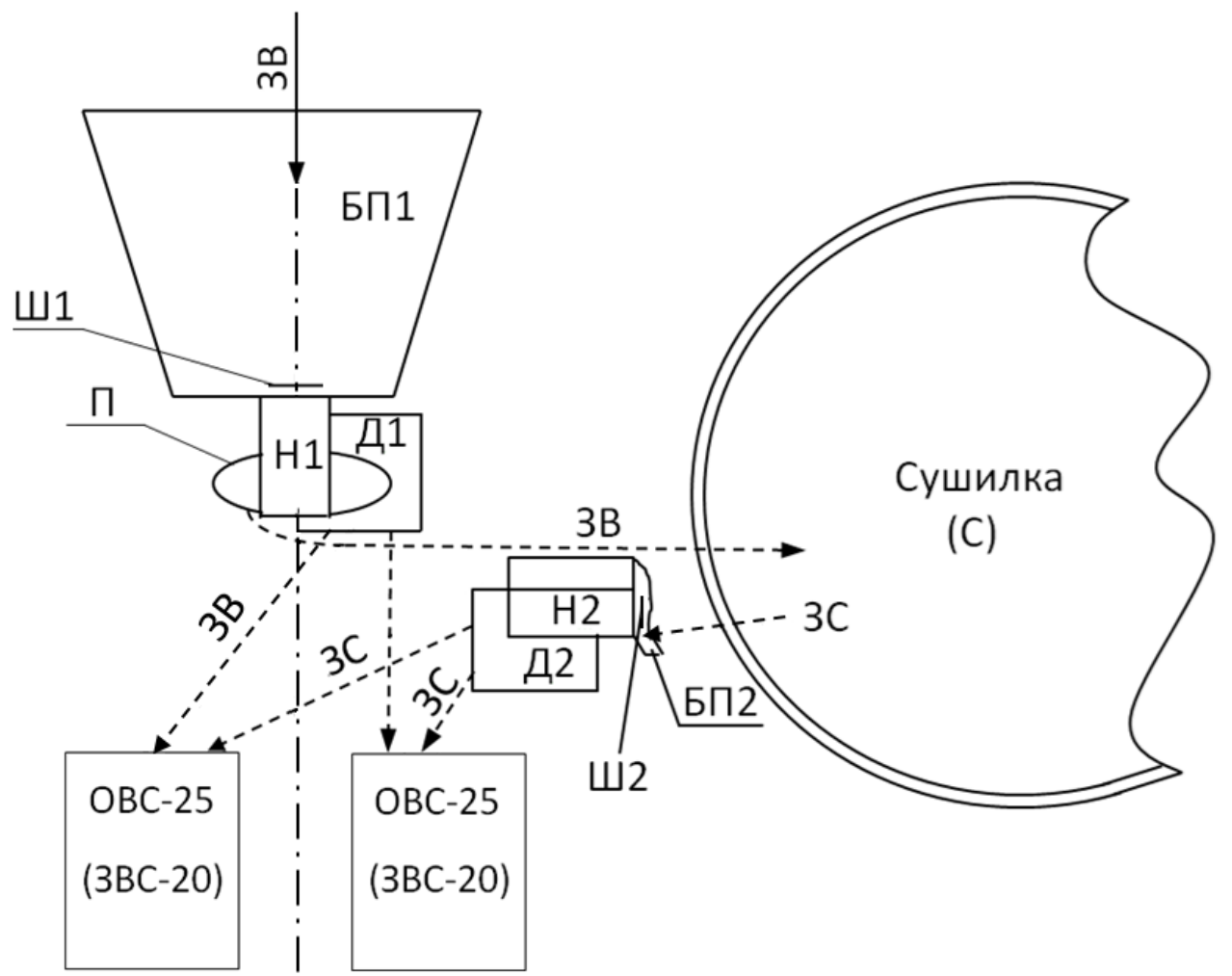

Рисунок 2 - Схема технологического процесса по 2-му варианту модернизации 
Вторая технологическая задача, состоящая в сортировке просушенного зернового вороха (3С) и одновременной дозагрузке сушилки $(\mathrm{C})$, осуществляется следующим образом. Подсушенный зерновой ворох (3С) из сушилки (C) самотеком поступает в приемный бункер (БП2). Далее зерно при открытом шибере (Ш2) поступает в башмак нории (Н2) и подается в каскадный делитель потока зерна (Д2), а из отводов делителя (Д2) по зернопроводам поступает на зерноочистительные машины ОВС-25 или ЗВС-20. При этом дозагрузка сушилки осуществляется в последовательности, указанный выше - по составу операций, необходимых для решения 1-ой технологической задачи.

Третья технологическая задача решается по последовательности операций второй задачи, но без дозагрузки сушилки (C) исходным зерновым ворохом (3В).

Четвертая технологическая задача, состоящая в сортировке исходного зернового вороха (без его подсушки), осуществляется следующим образом. Зерновой ворох (3В) из приемного бункера (Ш1) поступает в башмак нории (H1) и подается через переключатель (П) в делитель (Д1). Далее из отводов делителя (Д1) по зернопроводам зерновой ворох поступает на зерноочистительные машины ОВС-25 или 3ВС-20.

Последовательности операции по четырем технологическим задачам при 2-ом варианте модернизации будут следующими:

1) $3 \mathrm{~B} \rightarrow$ БП1 $\rightarrow$ Ш1 $\rightarrow \mathrm{H} 1 \rightarrow \Pi \rightarrow \mathrm{C}$;

2) $3 \mathrm{C} \rightarrow \mathrm{C} \rightarrow$ БП2 $\rightarrow$ Ш2 $\rightarrow$ H2 $\rightarrow$ Д2 $\rightarrow$ OВC-25 (ЗВС-20)+операции по п.1;

3) $3 \mathrm{C} \rightarrow \mathrm{C} \rightarrow$ БП2 $\rightarrow$ Ш2 $\rightarrow \mathrm{H} 2 \rightarrow$ Д2 $\rightarrow$ OBC-25 (3ВC-20);

4) ЗВ $\rightarrow$ БП1 $\rightarrow$ Ш1 $\rightarrow$ Н1 $\rightarrow$ П Д1 $\rightarrow$ OВC-25 (ЗВС-20).

Из приведенных выше последовательностей операций видно, что совместно нории (Н1) и (Н2) работают только при решении 2-ой технологической задачи. То есть, существующие две нории, сохраненные во втором варианте модернизации, используются в частичном режиме загрузки по времени. Следовательно расчетные оценки экономии затрат на электроэнергию для 1-го варианта модернизации будут еще меньшими. Однако, главным в предложенной модернизации зерноочистительно-сушильного комплекса является обеспечение управляемости технологии по загрузке основного оборудования с использованием авторегулируемых делителей потока сыпучих материалов каскадного исполнения $[1,2]$.

Каскадные делители потока зерна при равных расходных характеристиках с делителями жалюзийного типа [3] имеют в сравнении с ними меньшие вертикальные габариты в 1,5 - 1,7 раза, что расширяет их применение при модернизации зерноочистительных агрегатов, где технологическая высота всегда ограничена. Каскадные делители просты в изготовлении и имеют достаточный уровень качества деления потока. При подаче $1,5-7$ кг/с зерносмеси в стабилизирующую емкость к задней стенке погрешность деления не превышает 5 \%. При ограничении стабилизирующей емкости до ширины отвода, когда процесс истечения зерносмеси стабилизируется боковыми стенками, погрешность деления снижается до 1,74 \%.

Без использования предложенных средств управления массовыми потоками зерна невозможно избежать перекоса в загрузке технологических каналов, что является причиной снижения качества процесса очистки зерна по показателям остаточной засоренности и прямых потерь. В существующих технологиях подработки зерна нет эффективных средств управления массовыми потоками. Флажковые, призменные и тарельчатые делители [4 - 6] допускают отклонения расходов разделяемых потоков зерна $>150 \%$, что приводит к утрате работоспособности части оборудования и дополнительным потерям полноценного зерна. В фураже и отходах при использовании существующих технологий содержится $25-67 \%$ зерновок основной культуры от общей массы с малоценными компонентами.

Если сопоставить величину технологических потерь при использовании существующих технологий с затратами на их модернизацию с целью повышения качества процесса, то вполне эффективным окажется и 1-ый предложенный вариант с существенными затратами на монтажнодемонтажные работы. Снижение технологических потерь на 1,5 \% от существующего уровня при годовом объеме работ в 3000 - 4000 т позволит окупить все затраты на модернизацию уже в первый год эксплуатации модернизированной технологии.

Часто заказчики работ по модернизации зерноочистительных агрегатов (ЗАВ) сомневаются в наличии существенных резервов эффективности и их реализации за счет модернизации, что 
является следствием длительного пассивного (немотивированного) отношения к производству бесхозного отношения.

Между тем резервы эффективности огромные, а основная их доля приходится на снижение технологических потерь. Для условий рядовой эксплуатации зерноочистительных агрегатов в основных аграрноразвитых регионах России выход продовольственного зерна не превышает 70 \% от массы исходного зернового вороха [7]. По данным автора работы [8] на все компоненты зерновой и сорной примеси приходится 12,5 \%. Следовательно, потенциальный резерв повышения эффективности ЗАВ при их модернизации путем улучшения качества процессов очистки зерна состоит в снижении технологических потерь на 17,5 \%.

Во втором варианте совокупные затраты на модернизацию технологии, необходимые для технологической проработки проекта, корректировки конструкторской документации, изготовления и монтажа 2-х каскадных делителей составят 270 - 290 тыс. руб. Это в 1,5 раза меньше, чем затраты по первому варианту, но главное преимущество 2-го варианта заключается в более высоком уровне технологической надежности. При наличии двух перевалочных нории нет «дефицита» технологической высоты, надежнее работают зернопроводы, имеющие запас уклона, за счет чего обеспечивается большая равномерность зерновых потоков.

Выводы. Модернизация зерноочистительных технологий с использованием авторегулируемых делителей потока зерна обеспечивает значительный рост их эффективности (потенциал - до 17,5 \% снижения технологических потерь) и предопределена следующими причинами:

- зерноочистительные технологии реализуются в разноканальных вариантах механизации различных операций (перевалочные - в 1 или 2 канала, а технологические - в 4, 6 каналов), что требует деления потоков зерна от перевалочных средств на технологические в равных соотношениях;

- существующие делители флажкового, призменного и тарельчатого исполнений не обеспечивают качество деления (погрешность деления $>150$ \%), так как падающие потоки зерна меняют направление относительно делителей и геометрию сечения. Это снижает эффективность процессов по производительности и качеству, ограничивает (иногда исключает) работоспособность технологических машин;

- качественное деление (в заданных соотношениях) потока зерна возможно только при его сплошном истечении через все сечение канала (отверстия), но при этом неизбежно возникает сводообразование;

- созданные в ФГБНУ ВНИИТиН авторегулируемые делители потока зерна впервые в отечественной и зарубежной практике позволяют преодолеть указанное физическое противоречие и обеспечить стабильность сплошного истечения потока и его качественное (погрешность $<3 \%$ ) деление. Они используются в отечественных и зарубежных технологиях.

Включение в состав технологии сушилки карусельного типа усложняет ее управление из-за роста вариативности технологических реализаций процесса, требует дополнительного перевалочного средства. Предпочтительным вариантом модернизации этой технологии является сохранение двух перевалочных норий и их обеспечение авторегулируемыми делителями каскадного типа.

1. Патент РФ № 2520341 МПК А01F 12/44. Устройство для разделения потока сыпучих материалов / Тишанинов Н.П., Анашкин А.В., Тишанинов К.Н. - № 2012145368/13; заявл. 24.10.2012; опубл. 20.06.2014, Бюл. №17.

2. Патент РФ №2706163 МПК А01F 12/4. Устройство для разделения потока сыпучих материалов / Тишанинов Н.П., Анашкин А.В., Тишанинов К.Н. - №2019112704; заявл. 25.04.2019; опубл. 14.11.2019, Бюл. №32.

3. Тишанинов Н.П., Анашкин А.В., Тишанинов К.Н. Теоретическое обоснование технологических параметров каскадного делителя // Наука в центральной России. - 2019. №3 (39). - С. 56-67.

4. Лурье А.Б. Расчет и конструирование сельскохозяйственных машин. - Л.: Машиностроение, 1997. $-526 \mathrm{c}$.

5. Листопад Г.Е. Сельскохозяйственные и мелиоративные машины. - М.: Агропромиздат, 1986. -687 c. 
6. Соколов А.Я. Технологическое оборудование предприятий по хранению и переработке зерна. Изд. 4-е доп. и переработке зерна. Изд. 4-е доп. и перераб. - М.: Колос, 1975. - 495 с.

7. Тарасенко А.П., Оробинский В.И, Суднеев А.А., Шередякин В.В., Гиевский А.М. Влияние схемы размещения решет в решетном стане на фракционирование зернового вороха // Техника в сельском хозяйстве. - 2006. - № 3. - С. 32-34.

8. Московский М.Н. Идентификация процесса сепарации семян зерновых в зерноочистительных агрегатах // Дисс. канд. техн. наук. (05.20.01) - Ростов-на-Дону, 2005. - 218 с.

\title{
References.
}

1. Patent RF № 2520341 MPK A01F 12/44. Ustrojstvo dlja razdelenija potoka sypuchih materialov / Tishaninov N.P., Anashkin A.V., Tishaninov K.N. - № 2012145368/13; zajavl. 24.10.2012; opubl. 20.06.2014, Bjul. №17.

2. Patent RF №2706163 MPK A01F 12/4. Ustrojstvo dlja razdelenija potoka sypuchih materialov / Tishaninov N.P., Anashkin A.V., Tishaninov K.N. - №2019112704; zajavl. 25.04.2019; opubl. 14.11.2019, Bjul. №32.

3. Tishaninov N.P., Anashkin A.V., Tishaninov K.N. Teoreticheskoe obosnovanie tehnologicheskih parametrov kaskadnogo delitelja // Nauka v central'noj Rossii. - 2019. - №3 (39). - S. 56-67.

4. Lur'e A.B. Raschet i konstruirovanie sel'skohozjajstvennyh mashin. - L.: Mashinostroenie, 1997. - $526 \mathrm{~s}$.

5. Listopad G.E. Sel'skohozjajstvennye i meliorativnye mashiny. - M.: Agropromizdat, 1986. - $687 \mathrm{~s}$.

6. Sokolov A.Ja. Tehnologicheskoe oborudovanie predprijatij po hraneniju i pererabotke zerna. Izd. 4-e dop. i pererabotke zerna. Izd. 4-e dop. i pererab. - M.: Kolos, 1975. - 495 s.

7. Tarasenko A.P., Orobinskij V.I, Sudneev A.A., Sheredjakin V.V., Gievskij A.M. Vlijanie shemy razmeshhenija reshet $\mathrm{v}$ reshetnom stane na frakcionirovanie zernovogo voroha // Tehnika $\mathrm{v}$ sel'skom hozjajstve. - 2006. - № 3. - S. 32-34.

8. Moskovskij M.N. Identifikacija processa separacii semjan zernovyh v zernoochistitel'nyh agregatah // Diss. kand. tehn. nauk. (05.20.01) - Rostov-na-Donu, 2005. - $218 \mathrm{~s}$.

\section{Сведения об авторах}

\section{Принадлежность к организации}

Тишанинов Николай Петрович - доктор технических наук, профессор, главный научный сотрудник Федерального государственного бюджетного научного учреждения «Всероссийский научно-исследовательский институт использования техники и нефтепродуктов в сельском хозяйстве», Россия, г. Тамбов, e-mail: vniitinlab5@mail.ru.

\section{Author credentials}

\section{Affiliations}

Tishaninov Nikolai - Full Doctor of Technical Sciences, Professor, Chief Researcher of Federal State Budgetary Scientific Institution "All-Russian Research Institute for Use of Machinery and Petroleum Products in Agriculture”, Russia, Tambov, e-mail: vniitinlab5@mail.ru.

Поступила в редакцию (Received): 04.06.2020 Принята к публикации (Accepted): 10.07.2020

УДК 631.303

DOI: $10.35887 / 2305-2538-2020-4-11-17$

\section{ОЩЕНКА ПРЕИМУЩЕСТВА НАКЛОННОГО ИСПОЛНЕНИЯ ЩЕЛЕВОЙ СТЕНКИ ЖАЛЮЗИЙНОГО ДЕЛИТЕЛЯ ПОТОКА ЗЕРНА}

\author{
${ }^{1}$ Тищанинов Константин Николаевич \\ ${ }^{1}$ Тишанинов Николай Петрович \\ ${ }^{1}$ ФБНУ «Всероссийский научно-исследовательский институт \\ использования техники и нефтепродуктов в сельском хозяйстве»
}

Реферат. Известно, что среди разработанных видов делителей жалюзийный тип размещения щелевых отверстий обеспечивает наилучшее качество деления. Установлено, что при модернизации зерноочистительных агрегатов целесообразно использовать делители технологически ограниченные по высоте. Для повышения расходных характеристик делителя 
используют наклон разделительной стенки. При наклоне стенки делителя, через которую происходит истечение зерна, появляется вместе с горизонтальным истечением вертикальная составляюшая. Причем расход зерна через горизонтальное отверстие в 3 - 4 раза выше чем через вертикальное. Угол наклона определяет соотношение горизонтального и вертикального истечения через жалюзийные каналь. Так при угле наклона в $90^{\circ}$ происходит только вертикальное истечение. При наклоне вертикальной стенки меняются не только расходные характеристики отводов, но и характер взаимодействия сыпучего материала с жалюзийными отверстиями. Для оценки качества деления потока зерна устройством с наклонным размещением жалюзийных отверстий проведен теоретический анализ. За модель истечения зерна из стабилизирующей емкости вертикальным потоком была взята модель истечения зерна каскадного делителя с горизонтальным размещением каскадных отверстий, для наклонного делителя была взята модель истечения зерна каскадного делителя с наклонным размещением каскадных отверстий. Теоретический анализ показал возможность применения наклона вертикальной стенки делителя без существенной потери качества его работы. Несмещенная подача зерна в стабилизируюшую емкость с отклонением менее 5 см при использовании цุентрирующей горловины обеспечивает приемлемый уровень качества деления потока погрешность не более $10 \%$. Наклон стенки в 48, $6^{\circ}$ от вертикали позволяет увеличить расход зерна в 2,5 раза и сократить вертикальные габариты делителя в 2,2 раза.

Ключевые слова: делитель потока зерна, теоретический анализ, средства управления массовыми потоками зерна.

\title{
EVALUATING THE ADVANTAGES OF SLOPING SLOTTED WALL DESIGN OF A LOUVERED GRAIN FLOW DIVIDER
}

\section{${ }^{1}$ Tishaninov Konstantin \\ ${ }^{1}$ Tishaninov Nikolay

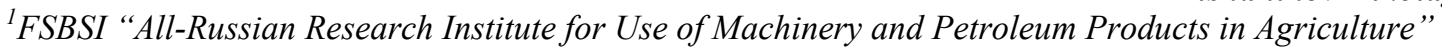

\begin{abstract}
It is known that among the developed types of dividers, the louver type of slot hole placement provides the best quality of division. It was found that when upgrading grain cleaning units, it is advisable to use dividers that are technologically limited in height. To increase the flow characteristics of the divider, use the slope of the dividing wall. When the divider wall is tilted through which the grain flows, a vertical component appears along with the horizontal flow. Moreover, the consumption of grain through a horizontal hole is 3-4 times higher than through a vertical one. The angle of inclination determines the ratio of horizontal and vertical flow through the louver channels. So when the angle of inclination is 900, only the vertical expiration occurs. When the vertical wall is tilted, not only the flow characteristics of the bends change, but also the nature of the interaction of the bulk material with the louver holes. To assess the quality of grain flow division by a device with an inclined placement of louver holes, a theoretical analysis was performed. The model of the expiration of the grain of the stabilising capacity of vertical flow was modelled expiry of grain cascaded divider with horizontal placement of cascading holes for the horizontal divider is expiry of grain cascaded divider with a slanted placement of cascading holes. Theoretical analysis has shown the possibility of using the vertical wall tilt divider without significant loss of quality of its operation. An unbiased feed of grain to a stabilizing container with a deviation of less than $5 \mathrm{~cm}$ when using a centering neck provides an acceptable level of quality of flow division - an error of no more than 10\%. The wall slope of 48.60 from the vertical allows you to increase the grain consumption by 2.5 times and reduce the vertical dimensions of the divider by 2.2 times.
\end{abstract}

Keywords: grain flow divider, theoretical analysis, tools for controlling mass grain flows.

Введение. Известны делители потока сыпучих материалов жалюзийного типа [1 - 4] с вертикальной стабилизирующей емкостью. Они просты по конструкции и обеспечивают достаточно высокий уровень качества деления потока. Однако, из-за низкой интенсивности истечения сыпучего материала через щелевые каналы в вертикальной стенке они имеют значительные габариты по высоте, что ограничивает их применение при реконструкции существующих зерноочистительных агрегатов, которые не имеют запаса технологической высоты, 
а их использование без средств управления массовыми потоками зерна малоэффективно или убыточно. При расходной характеристике делителя жалюзийного типа в 50 т/ч, например, его габарит с отводами составляет 1,7 м. Возможности снижения вертикальных габаритов за счет увеличения ширины стабилизирующей емкости и, как следствие, длины целевых каналов приводит к снижению качества процесса. Поэтому рассмотрение возможности увеличения расходных характеристик делителей жалюзийного типа за счет наклона стенки с щелевыми отводными каналами представляет собой актуальную задачу.

Результаты и их обсуждение. Делитель с размещением щелевых отверстий в наклонной стенке должен обладать большими расходными характеристиками. Известно, что удельный расход зерна через горизонтальное отверстие в 3 - 4 раза выше чем через вертикальное. Предполагаемое увеличение производительности делителя с размещением щелевых отверстий в наклонной составит 50 - 150 \% при наклоне стенки на 30 - 60 градусов в сравнении с вертикальным делителем. Для более точной оценки количественных и качественных характеристик делителя необходимо провести теоретический анализ.

Рассмотрим конструктивно-технологическую схему наклонного делителя и его работу (рисунок 1).
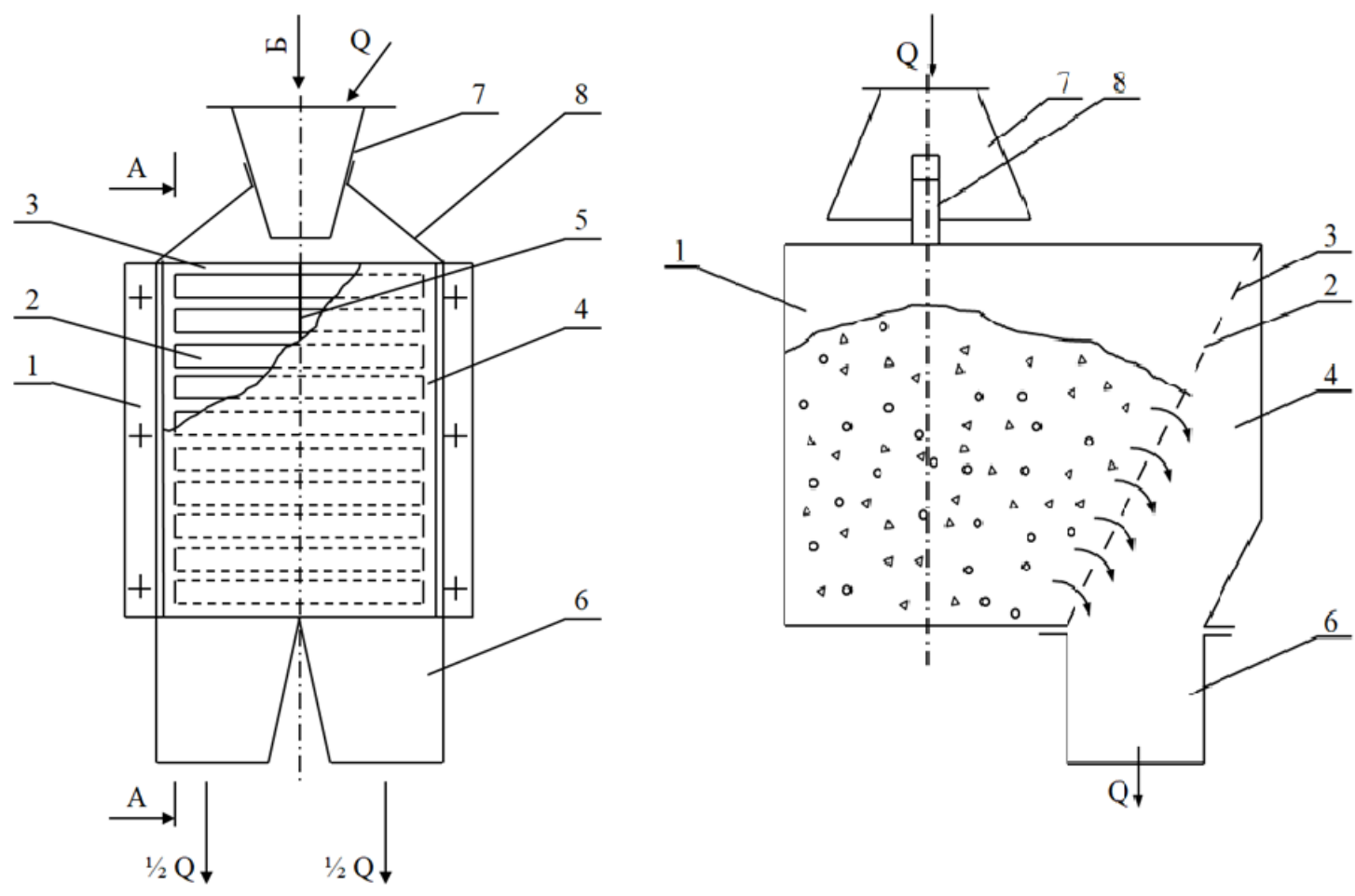

Рисунок 1 - Схема делителя с наклонным размещением щелевых отверстий

Устройство для разделения сыпучих материалов содержит стабилизирующую емкость 1 с щелевыми отводящими каналами 2 в боковой стенке 3, корпус 4 с перегородкой 5, патрубки 6, приемную горловину 7 с планками 8. В стабилизирующую емкость 1 через приемную горловину 7, закрепленную на стабилизирующей емкости 1 планками 8, подается зерно. По мере увеличения подачи зерна в стабилизирующую емкость 1 увеличивается число включенных в работу щелевых отводящих каналов 2, выполненных в боковой стенке 3, через которые зерно попадает в полость корпуса 4, разделенного перегородкой 5, и далее - в патрубки 6, увеличивая их расходные характеристики. При уменьшении подачи зерна в стабилизирующую емкость 1 число включенных в работу щелевых отводящих каналов 2 и расходные характеристики патрубков 6 уменьшаются. 
Таким образом, осуществляется процесс авторегулирования деления потока и поддержания стабилизирующего слоя зерна в необходимом диапазоне высот наклон боковой стенки 3 к горизонту повышает интенсивность истечения зерна через щелевые отводящие каналы 2 , обеспечивая рост расходных характеристик при равных габаритах устройства, что расширяет область его применения.

Для оценки качества разделения делителя с наклонным размещением щелевых отверстий сравним его работу с вертикальным делителем. В работе [5] определена погрешность деления потоков зерна делителем с горизонтальным размещением каскадных отверстий. Для вертикального делителя примем, что площадь поверхности, через которое происходит истечение, равна половине площади $\mathrm{S}$, вычисляемой по формулам $(1,2)$ (Рисунок 2).

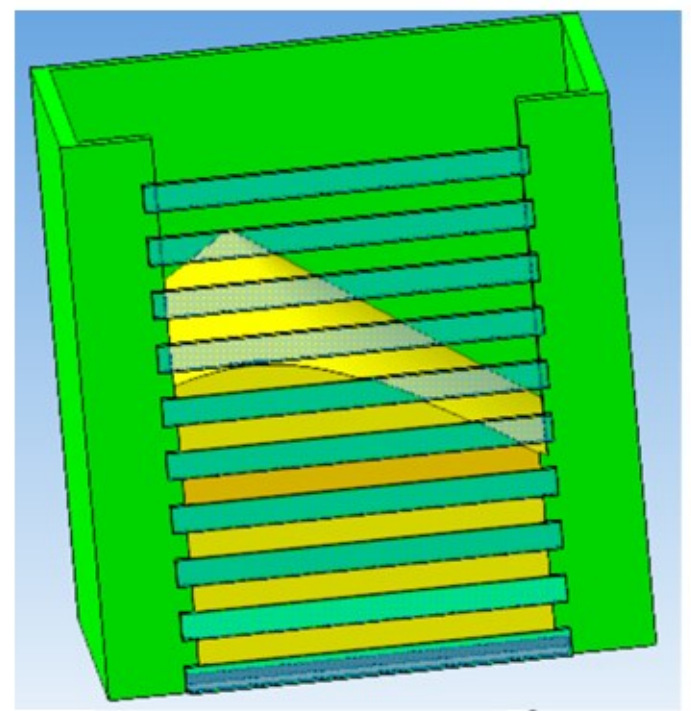

(a)

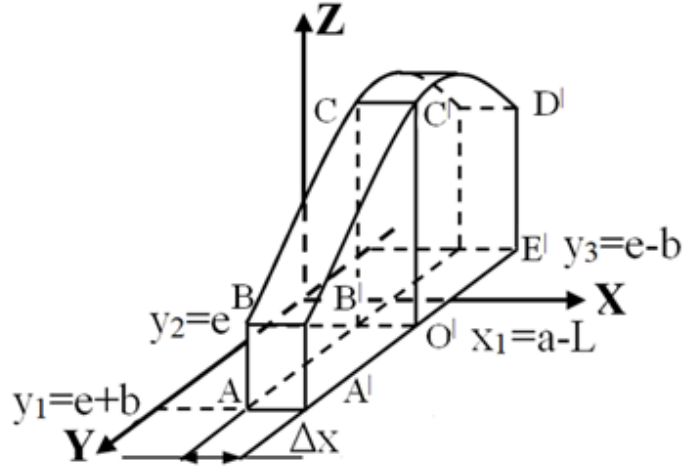

(б)

Рисунок 2 - Общий вид (a) и расчетная схема (б) расходных характеристик вертикального делителя

$$
S_{1}=\int_{e-b}^{e} d y \int_{0}^{H-\operatorname{tg}(\alpha) \cdot \sqrt{(L-a)^{2}+y^{2}}} d z=\int_{e-b}^{e}\left(H-\operatorname{tg}(\alpha) \cdot \sqrt{(L-a)^{2}+y^{2}}-0\right) d y=H(e-e+
$$

$b)-\operatorname{tg}(\alpha) \cdot\left(e \cdot \sqrt{(L-a)^{2}+e^{2}}-(e-b) \cdot \sqrt{(L-a)^{2}+(e-b)^{2}}\right) / 2-\operatorname{tg}(\alpha) \cdot(L-a)^{2}$.

$\left(\ln \left(|e|+\sqrt{(L-a)^{2}+e^{2}}\right)-\ln \left(|e-b|+\sqrt{(L-a)^{2}+(e-b)^{2}}\right)\right) / 2$.

$$
S_{2}=\int_{e}^{e+b} d y \int_{0}^{H-\operatorname{tg}(\alpha) \cdot \sqrt{(L-a)^{2}+y^{2}}} d z=\int_{e}^{e+b}\left(H-\operatorname{tg}(\alpha) \cdot \sqrt{(L-a)^{2}+y^{2}}-0\right) d y=H(e-e+
$$

b) $-\operatorname{tg}(\alpha) \cdot\left((e+b) \cdot \sqrt{(L-a)^{2}+(e+b)^{2}}-e \cdot \sqrt{(L-a)^{2}+e^{2}}\right) / 2-\operatorname{tg}(\alpha) \cdot(L-a)^{2}$.

$\left(\ln \left(|e+b|+\sqrt{(L-a)^{2}+(e+b)^{2}}\right)-\ln \left(|e|+\sqrt{(L-a)^{2}+e^{2}}\right)\right) / 2$.

$$
\begin{aligned}
& S_{11}=\frac{S_{1}}{2} ; \\
& S_{22}=\frac{S_{2}}{2} .
\end{aligned}
$$

Тогда погрешность деления вертикального делителя будет равна погрешности деления делителя с горизонтальным размещением каскадных отверстий (формула 3):

$$
\Delta_{11}=\frac{S_{11}-S_{22}}{S_{11}}=\frac{\frac{S_{1}}{2}-\frac{S_{2}}{2}}{\frac{S_{1}}{2}}=\frac{S_{1}-S_{2}}{S_{1}}=\Delta_{1} ;
$$

Погрешность деления потока делителем с наклонным размещением щелевых отверстий вычисляется по формулам $(4,5,6)$, указанных в работе [6], рисунок 3. 


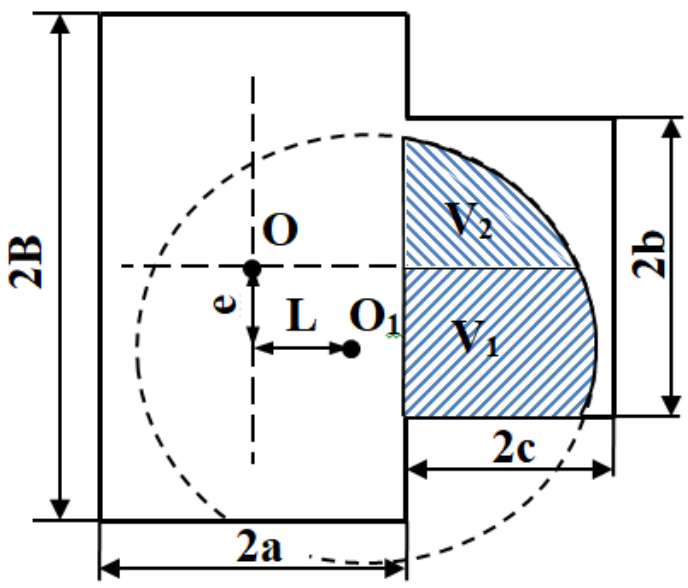

(a)

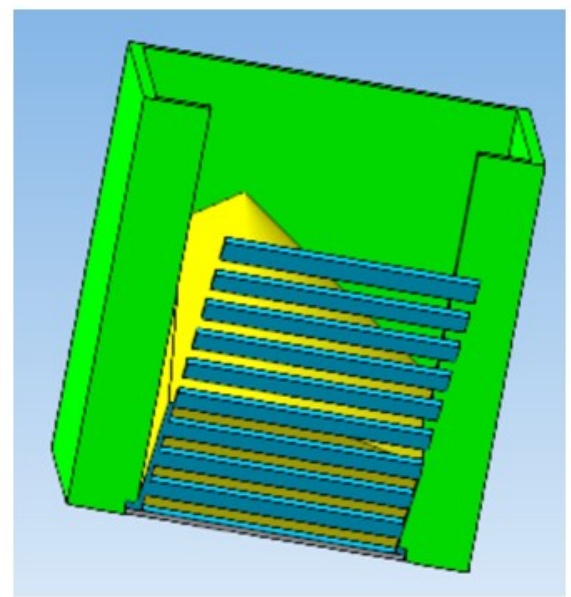

(б)

Рисунок 3 - Ассиметричная подача сыпучего материала в наклонный делитель: вид сверху (a), общий вид (б)

$$
\begin{aligned}
& V_{1}=\int_{a-L}^{\frac{H-(L-a),}{\operatorname{tg}(\alpha)+1}}(H+a-\mathrm{L}-\mathrm{x})(\mathrm{e}-\mathrm{e}+\mathrm{b})-\operatorname{tg}(\alpha)\left(\frac{e}{2} \sqrt{x^{2}+e^{2}}\right. \\
& \left.-\frac{e-b}{2} \sqrt{x^{2}+(e-b)^{2}}+\frac{x^{2}}{2} \ln \left|e+\sqrt{x^{2}+e^{2}}\right|-\frac{x^{2}}{2} \ln || e-b\left|+\sqrt{x^{2}+e^{2}}\right|\right) d x \\
& =(H+a-L)\left(d_{1}-d_{2}\right) b-\frac{d_{1}{ }^{2}-d_{2}{ }^{2}}{2} b-\operatorname{tg}(\alpha) \frac{e}{2}\left(\frac{d_{1}}{2} \sqrt{d_{1}{ }^{2}+e^{2}}-\frac{d_{2}}{2} \sqrt{d_{2}{ }^{2}+e^{2}}\right) \\
& -\frac{e^{3}}{4} \operatorname{tg}(\alpha)\left(\ln \left|d_{1}+\sqrt{d_{1}{ }^{2}+e^{2}}\right|-\ln \left|d_{2}+\sqrt{d_{2}{ }^{2}+e^{2}}\right|\right)+\frac{e-b}{2} \operatorname{tg}(\alpha)\left(\frac{d_{1}}{2} \sqrt{d_{1}{ }^{2}+(e-b)^{2}}-\right. \\
& \left.\frac{d_{2}}{2} \sqrt{d_{2}{ }^{2}+(e-b)^{2}}\right)+\frac{(e-b)^{3}}{4} \operatorname{tg}(\alpha)\left(\ln \left|d_{1}+\sqrt{d_{1}{ }^{2}+(e-b)^{2}}\right|-\ln \left|d_{2}+\sqrt{d_{2}{ }^{2}+(e-b)^{2}}\right|\right)- \\
& \frac{\operatorname{tg}(\alpha)}{6}\left(d_{1}{ }^{3} \ln \left|e+\sqrt{d_{1}{ }^{2}+e^{2}}\right|-d_{2}{ }^{3} \ln \left|e+\sqrt{d_{2}{ }^{2}+e^{2}}\right|\right)-\frac{\operatorname{tg}(\alpha)}{12} e\left(d_{1} \sqrt{d_{1}{ }^{2}+e^{2}}-d_{2} \sqrt{d_{2}{ }^{2}+e^{2}}\right)+ \\
& \frac{\operatorname{tg}(\alpha)}{12} e^{3}\left(\ln \left|d_{1}+\sqrt{d_{1}{ }^{2}+e^{2}}\right|-\ln \left|d_{2}+\sqrt{d_{2}{ }^{2}+e^{2}}\right|\right)+ \\
& \frac{\operatorname{tg}(\alpha)}{6}\left(d_{1}{ }^{3} \ln || e-b\left|+\sqrt{d_{1}{ }^{2}+(e-b)^{2}}\right|-d_{2}{ }^{3} \ln || e-b\left|+\sqrt{d_{2}{ }^{2}+(e-b)^{2}}\right|\right)+\frac{\operatorname{tg}(\alpha)}{12} \mid e- \\
& b\left|\left(d_{1} \sqrt{d_{1}{ }^{2}+(e-b)^{2}}-d_{2} \sqrt{d_{2}{ }^{2}+(e-b)^{2}}\right)-\frac{\operatorname{tg}(\alpha)}{12}\right| e-\left.b\right|^{3}\left(\ln \left|d_{1}+\sqrt{d_{1}{ }^{2}+(e-b)^{2}}\right|-\right. \\
& \left.\ln \left|d_{2}+\sqrt{d_{2}^{2}+(e-b)^{2}}\right|\right) \text {. }
\end{aligned}
$$

Аналогичным образом найдем объем $\mathrm{V}_{2}$ :

$$
\begin{gathered}
V_{2}=\int_{a-L}^{\frac{H-(L-a),}{t g(\alpha)+1}} d x \int_{e}^{e+b} d y \int_{x+(L-a)}^{H-t g(\alpha) \cdot \sqrt{x^{2}+y^{2}}} d z . \\
\Delta_{22}=\frac{V_{1}-V_{2}}{V_{1}}
\end{gathered}
$$

Как видно на графике 3 делитель с наклонным размещением щелевых отверстий дает большую погрешность деления при тех же значениях горизонтального смещения подаваемого потока (е) чем вертикальный делитель. Однако при минимальном смещении потока с использованием центрирующей горловины качество деления потока зерна приемлемо для существующих технологий. 


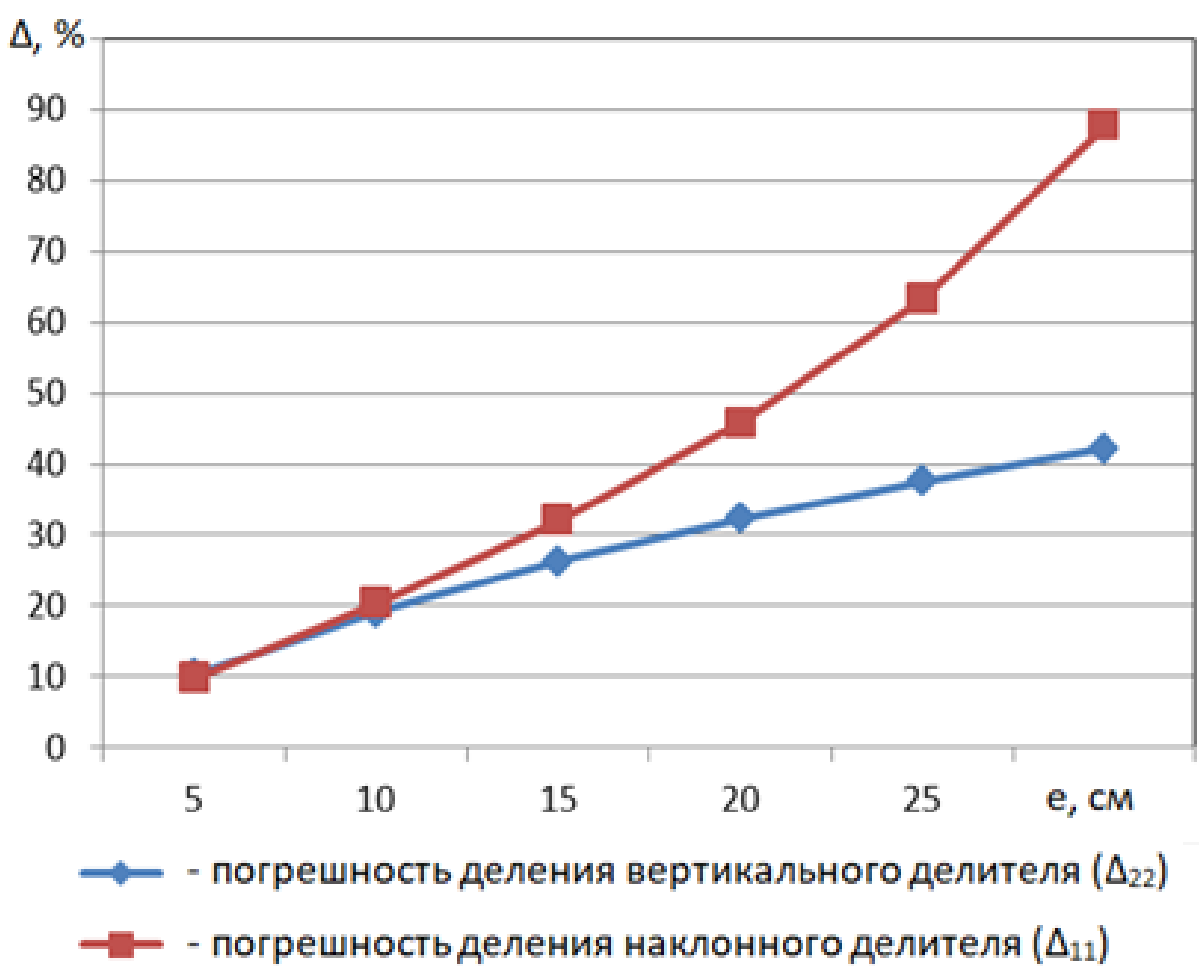

Рисунок 3 - Погрешности деления потока с использованием делителей с наклонным $\left(\Delta_{11}\right)$ и вертикальным размещениями отверстий $\left(\Delta_{22}\right)$ от величины горизонтального смещения потока зерна $(\mathrm{e})$

Расходные характеристики делителя с наклонной стенкой должны увеличиться. Примем, что при истечении зерна через горизонтальные каналы расходные характеристики при той же площади проходного отверстия в 3 раза больше чем при истечении зерна через вертикально расположенные каналы. Для нахождения расходных характеристик делителя с наклонным размещением отводящих каналов примем, что его величина (Q) определяется в зависимости от угла $(\alpha)$ по следующей формуле (7):

$$
Q(\alpha)=q+2 q \sin (\alpha) .
$$

Увеличение наклонна стенки делителя позволяет увеличивать его производительность, не увеличивая технологическую высоту (таблица 1).

Таблица 1 - Зависимость увеличение производительности делителя (Q) от угла наклона его стенки $(\alpha)$

\begin{tabular}{|l|c|c|c|c|c|}
\hline Производительность Q $(\alpha)$ & $\mathrm{Q}$ & $1,5 \mathrm{Q}$ & $2 \mathrm{Q}$ & $2,5 \mathrm{Q}$ & $3 \mathrm{Q}$ \\
\hline Угол наклона стенки $(\alpha)$ & $0^{0}$ & $14,5^{0}$ & $30^{0}$ & $48,6^{0}$ & $90^{0}$ \\
\hline
\end{tabular}

Выводы. Теоретический анализ показал, что применение делителя с наклонным размещением щелевых каналов позволяет увеличить производительность, сохраняя его габариты по высоте. Погрешность деления при этом увеличивается с 26,3 \% до 32 \% при величине горизонтального смещения подачи в 15 см и с $42 \%$ до 87,6 \% при подаче зерна в боковую стенку.

При смещении подачи $<5$ см погрешность деления не превышает $10 \%$, что приемлемо для существующих зерноочистительных технологий, в которых используются флажковые, призменные и тарельчатые делители с погрешностью деления на порядок превышающий достигнутый уровень.

\section{Список литературы}

1. Патент РФ № 2459405, МПК С1, А01F12/46. Устройство для разделения потока сыпучих материалов // Тишанинов Н.П., Тишанинов К.Н. - 2011110258/13; Заявлено 17.03.2011; Опубл. 27.08.2012. Бюл. № 24. 
2. Патент РФ № 2490863, МПК С1, А01F12/46. Устройство для разделения потока сыпучих материалов // Тишанинов Н.П. Тишанинов К.Н. Растюшевский К.А. - 2012113182/13, Заявлено 04.04.2012; Опубл. 27.08.2013. Бюл. № 24.

3. Патент РФ № 2520341, МПК C1, А01F12/44. Устройство для разделения потока сыпучих материалов // Тишанинов Н.П., Анашкин А.В., Тишанинов К.Н. - 2012145368/13; Заявлено 24.10.2012; Опубл. 20.06.14. Бюлл. № 17.

4. Патент РФ № 2706163, МПК C1, А01F12/46. Устройство для разделения потока сыпучих материалов // Тишанинов Н.П., Анашкин А.В., Тишанинов К.Н. - 2019112704/19; Заявлено 25.04.2019; Опубл. 14.11.2019. Бюл. № 32.

5. Тишанинов К.Н., Анашкин А.В. Теоретическое обоснование конструктивных параметров делителя с горизонтальным размещением щелевых отверстий // Вестник АПК Верхневолжья.2019. - № 2 (46), - С. 62 - 66 .

6. Анашкин А.В., Тишанинов К.Н. Теоретическое обоснование технологических параметров каскадного делителя // Наука в центральной России.- 2019. - № 3 (39), - С. 56 - 60.

\section{References}

1. Patent RF № 2459405, MPK S1, A01F12/46. Ustrojstvo dlja razdelenija potoka sypuchih materialov // Tishaninov N.P., Tishaninov K.N. - 2011110258/13; Zajavleno 17.03.2011; Opubl. 27.08.2012. Bjul. № 24 .

2. Patent RF № 2490863, MPK S1, A01F12/46. Ustrojstvo dlja razdelenija potoka sypuchih materialov // Tishaninov N.P. Tishaninov K.N. Rastjushevskij K.A. - 2012113182/13, Zajavleno 04.04.2012; Opubl. 27.08.2013. Bjul. № 24.

3. Patent RF № 2520341, MPK S1, A01F12/44. Ustrojstvo dlja razdelenija potoka sypuchih materialov // Tishaninov N.P., Anashkin A.V., Tishaninov K.N. - 2012145368/13; Zajavleno 24.10.2012; Opubl. 20.06.14. Bjull. № 17.

4. Patent RF № 2706163, MPK S1, A01F12/46. Ustrojstvo dlja razdelenija potoka sypuchih materialov // Tishaninov N.P., Anashkin A.V., Tishaninov K.N. - 2019112704/19; Zajavleno 25.04.2019; Opubl. 14.11.2019. Bjul. № 32 .

5. Tishaninov K.N., Anashkin A.V. Teoreticheskoe obosnovanie konstruktivnyh parametrov delitelja s gorizontal'nym razmeshheniem shhelevyh otverstij // Vestnik APK Verhnevolzh'ja.-2019. - № 2 (46), - S. $62-66$.

6. Anashkin A.V., Tishaninov K.N. Teoreticheskoe obosnovanie tehnologicheskih parametrov kaskadnogo delitelja // Nauka v central'noj Rossii.- 2019. - № 3 (39), - S. 56 - 60.

\section{Сведения об авторах}

\section{Принадлежность к организации}

Тишанинов Константин Николаевич - кандидат технических наук старший научный сотрудник Федерального государственного бюджетного научного учреждения «Всероссийский научно-исследовательский институт использования техники и нефтепродуктов в сельском хозяйстве», Россия, г. Тамбов, e-mail: TishaninovKN@rambler.ru.

Тишанинов Николай Петрович - доктор технических наук, профессор, главный научный сотрудник Федерального государственного бюджетного научного учреждения «Всероссийский научно-исследовательский институт использования техники и нефтепродуктов в сельском хозяйстве», Россия, г. Тамбов, e-mail: vniitinlab5@mail.ru.

\section{Author credentials}

\section{Affiliations}

Tishaninov Konstantin - Candidate of Technical Sciences, Senior Researcher of Federal State Budgetary Scientific Institution "All-Russian Research Institute for Use of Machinery and Petroleum Products in Agriculture”, Russia, Tambov, e-mail: TishaninovKN@rambler.ru.

Tishaninov Nikolai - Full Doctor of Technical Sciences, Professor, Chief Researcher of Federal State Budgetary Scientific Institution "All-Russian Research Institute for Use of Machinery and Petroleum Products in Agriculture”, Russia, Tambov, e-mail: vniitinlab5@mail.ru.

Поступила в редакцию (Received): 03.07.2020 Принята к публикации (Accepted): 17.08.2020 
УДК 631.243

DOI: $10.35887 / 2305-2538-2020-4-18-26$

\title{
ИССЛЕДОВАНИЕ ТЕХНОЛОГИЧЕСКОГО ПРОЦЕССА КОНТЕЙНЕРНОЙ ЗАГОТОВКИ СЕЛЕКЦИОННОГО ЗЕРНА В УСЛОВИЯХ ПЕРВИЧНОГО РАЗМНОЖЕНИЯ
}

\author{
${ }^{1}$ Степанов Кирилл Александрович \\ ${ }^{1}$ Иванов Максим Викторович \\ ${ }^{1}$ Крюков Михаил Львович \\ ${ }^{1}$ ФГБНУ «Федеральный научный агроинженерный центр ВИМ»
}

Реферат. В традииионном транспортно-технологическом процессе заготовки селекционных семян зерновых культур в мешкотару межоперационные погрузочно-разгрузочные работы выполняются с применением преимущественно ручного труда и ведут к затратам и потерям зерна до 20-33\% ежегодно или до 35 mыс. руб./га. В результате изучения аспектов, связанных с механизачией ручного труда на погрузочно-разгрузочных работах, пришли к выводу о необходимости замены мягкой упаковки на многофункииональную контейнерную, позволяющую совмещение операций транспортировки, перегрузки, сушки и хранения с применение подъёмнотранспортных устройств, машини механизмов. Экономический эффект от решения задачи механизации при устранении выше приведённых затрат позволит закупить технику на сумму до 137.5 mыс. руб/га. Проведены исследования временных характеристик типового уборочнотранспортного процесса и первичной обработки на примере уборки 7 га овса «Яков». Установлено, что затраты времени на погрузку 0.5 тонн зерна в один контейнер в 16 раз меньше, чем в 14 мешков, весом по 35 кг/шт на один поддон, при перемешении контейнера и поддона крюковым манипулятором - 39 секунд. Исследован вопрос сушки селекционного зерна $в$ контейнере с использованием реверсирования агента сушки. Установлено, что использование реверса снижает время сушки на 14-15\%, а конечную температуру зерна в нижнем слое на 1,5 2 град. Теоретически было выведено трёхфакторное уравнение времени такой сушки, которое показало близость расчётов к результатам экспериментальных исследований реверсивной сушки. Суммарный экономический эффект от внедрения сушильно-транспортньх контейнеров грузоподъёмностью 500 кг взамен мягкой упаковки на этапах уборки, транспортировки, сушки и хранения, в зависимости от валового сбора (до $400 \mathrm{~m}$ ) составит, в среднем, 58,8\%.

Ключевые слова: селекция; первичное семеноводство; транспортно-технологический процесс; мешкотара, контейнерная упаковка, снижение затрат.

\section{RESEARCH OF TECHNOLOGICAL PROCESS OF CONTAINER PREPARATION OF SELECTION GRAIN IN CONDITIONS OF PRIMARY REPRODUCTION}

\author{
${ }^{1}$ Stepanov Kirill \\ ${ }^{1}$ Ivanov Maxim \\ ${ }^{1}$ Kryukov Michael

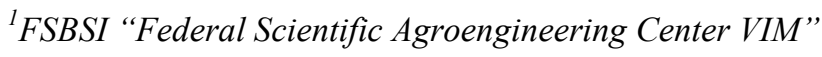

\begin{abstract}
Interoperational loading and unloading operations in the traditional transport and technological process of harvesting selection seeds of grain crops in sack tare are carried out using mainly manual labor and lead to costs and grain losses up to 20 - $33 \%$ annually or up to 35 thousand rubles/ha. As a result of studying the aspects related to the mechanization of manual labor in loading and unloading operations, we came to the conclusion that it is necessary to replace soft packaging with a multifunctional container one, which allows combining the operations of transportation, reloading, drying and storage with the use of lifting and transporting devices, machine mechanisms. The economic effect of solving the problem of mechanization while eliminating the above costs will allow you to purchase equipment for up to 137,5 thousand rubles/ha. Studies of the temporal characteristics of a typical harvesting and transport process and primary processing by the example of harvesting 7 hectares of Yakov oats were carried out It was found that the time required for loading 0.5 tons of grain into one container is 16 times less than in 14 bags, weighing $35 \mathrm{~kg} /$ piece per pallet; when moving the container
\end{abstract}


and pallet with a hook manipulator, the time is 39 seconds. The issue of drying selected grain in a container using a reverse drying agent is investigated. It was found that the use of reverse reduces the drying time by $14-15 \%$, and the final temperature of the grain in the lower layer by 1,5 - 2 degrees. The three-factor equation of the drying time, which showed the closeness of the calculations to the results of experimental studies of reverse drying, was derived theoretically. The total economic effect of the introduction of drying and transport containers with a load capacity of $500 \mathrm{~kg}$ instead of soft packaging at the stages of cleaning, transportation, drying and storage, depending on the gross collection (up to 400 tons), will be, on average, $58,8 \%$.

Keywords: selection; primary seed production; transport and technological process; bagging, container packaging, cost reduction.

Введение. Известен транспортно-технологический процесс, при котором селекционное зерно убирается комбайном в мешкотару, перевозится транспортным средством от поля к току, взвешивается, отправляется на временное хранение, сушится, сортируется и устанавливается на длительное хранение (рисунок 1).

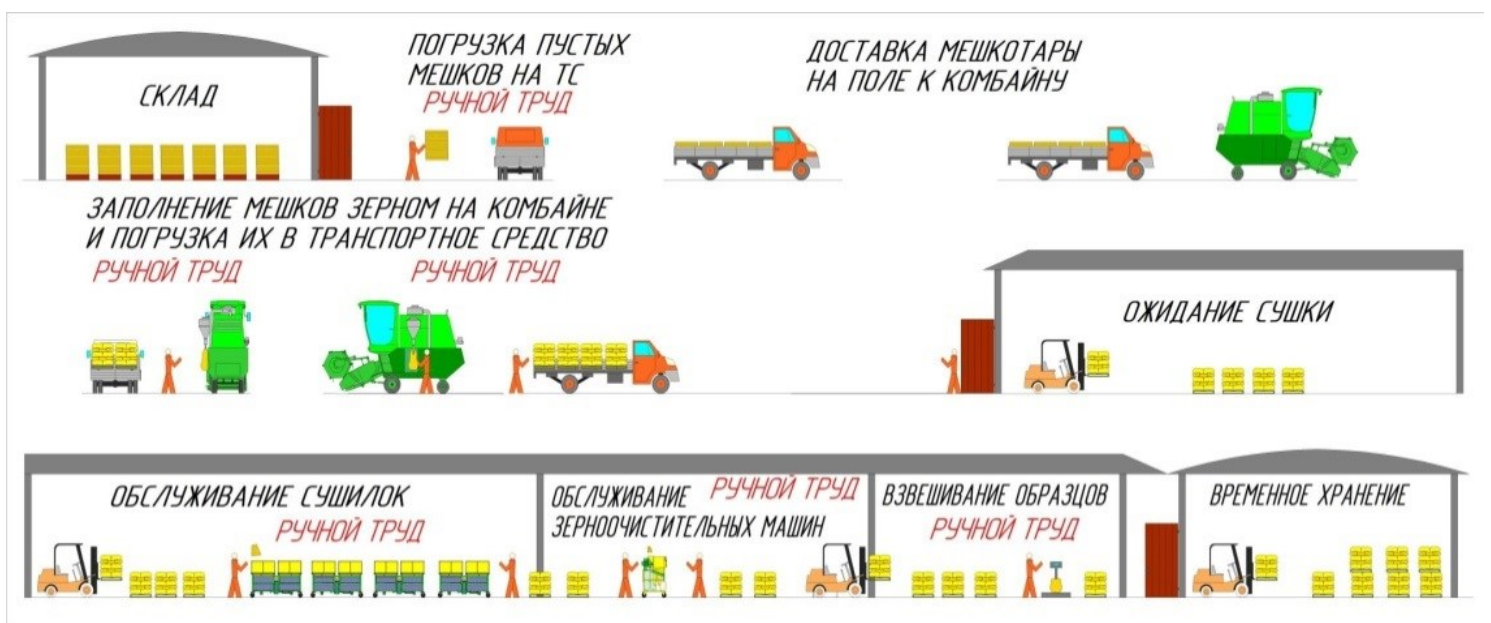

Рисунок 1 - Транспортно-технологический процесс «Мягкой тары» заготовки селекционных семян зерновых культур на III и IV этапе селекции и первичного семеноводства

В приведённой выше технологии подъёмно-транспортные работы выполняются с применением преимущественно ручного труда c ручной межоперационной перевалкой селекционного зерна в мягкой упаковке (мешках), что по экспертным оценкам, приводит к совокупным потерям зерна в $20-33$ \% ежегодно [1]. Это является существенным недостатком, поскольку при средней посевной площади в 4 га для каждого из 10 испытываемых сортов, урожайности селекционного хозяйства 44 ц/га и стоимости тонны зерна 12 тыс. руб./т годовые потери одного предприятия составляют ориентировочно 35 тыс. руб/га.

Рассчитана максимальная сумма покупки, либо модернизации техники, направленной на механизацию полевых погрузочных работ - до 137,5 тыс. руб/га, основанная на потерях материала, с поправкой на минимально приемлемую окупаемость в 5 лет. В настоящее время средства комплексной механизации погрузочно-разгрузочных работ отсутствуют.

Ручной труд в уборочно-транспортном процессе заготовки селекционного зерна составляет более $25 \%$, а на погрузочно-разгрузочных операциях - $100 \%$. Возможным решением проблемы механизации является разработка специальной контейнерной упаковки при базовой стоимости затрат на мягкую упаковку 2 тыс. руб./га, а возможности модернизации до 88 тыс. руб./га [1]. Контейнерная упаковка позволяет полностью механизировать ручной труд.

Материалы и методы. В соответствии с ГОСТ 34393-2018 экономическая эффективность разработки может определяться как минимизация прямых затрат $И_{\ni}^{i}$, руб/т, на весь объём работ $B_{i}$, т, на этапах уборки, транспортировки и сушки:

$$
C^{\sum i}=\sum_{i} B_{i} * h_{\ni}^{i} \rightarrow \min
$$


Так математическая модель уборочно-транспортного процесса основана на обороте совокупного валового объёма работ $B_{i}$, т, определяющегося суточным оборотом материала $Q_{\mathrm{c}}^{i}$, т, осуществлённый на этапах комбайнирования $(\kappa)$, транспортировки $(m)$ и сушки $(c)$ техническими средствами в необходимом количестве $X_{s}$ за отведённый агротехнический срок $T$, дн.

$$
B_{i}=Q_{c}^{i} * X_{s} * T, \mathrm{~T}
$$

Объёмы взаимосвязанных работ должны быть выполнены синхронизировано [1]. Для общей рассматриваемой системы «комбайн-транспортное средство-зерносушильная установка», синхронизация объёмов работ будет выглядеть следующим образом:

$$
Q_{c}^{\kappa} * X_{\kappa} * T \leq Q_{c}^{m} * X_{m} * T \leq Q_{c}^{c} * X_{c} * T .
$$

Применительно к работе комбайна, после первичного преобразования уравнение валового объёма работ имеет вид:

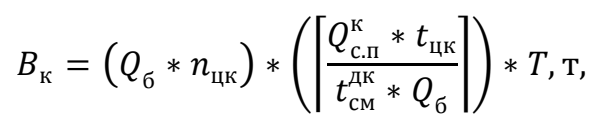

где $Q_{б}$, т - вместимость зернового бункера, определяющаяся объёмом зернового бункера $V_{б}, \mathrm{~m}^{3}$, плотностью зернового материала $\gamma_{\text {в }}$, т/м ${ }^{3}$ и коэффициентом заполнения бункера $K_{\text {зап }} ; n_{\text {цк }}$ количество циклов, совершаемое единичным комбайном в течение фактической смены, определяемое округлённым вниз отношением действительного времени смены $t_{\mathrm{cm}}^{\text {дк }}$ ч, учитывающего количество смен за 24 часа $k$, ед., затраты времени на ежесменное техническое обслуживание $t_{\text {то }}$, ч, отдых механизатора $t_{\text {отл }}$, ч, ко времени цикла $t_{\text {цк }}$, ч, складывающегося из времени загрузки бункера $t_{\text {бз }}$, п, поворотов $t_{\text {пов }}$, ч, и разгрузки бункера $t_{\text {разг }}$, ч.

Для определения потребного количества комбайнов $X_{\text {K }}$ (3) воспользуемся пропорцией сменных количеств циклов по времени и по весу, определяющихся соотношением сменной потребности сбора зерна $Q_{\text {с.п }}^{\text {к }}$, к, которая в свою очередь определяется валовым объёмным выходом испытываемых культур $V_{\Sigma}$, т, отнесённым к агросроку $T$, дн., и приумноженной необходимым нам количеством комбайнов $X_{\text {к }}$, ограничивающегося условием не превышения времени смены $t_{\mathrm{cm}}^{\text {дк }}$, вместимостью единичного зернового бункера $Q_{6}$.

Учитывая вышесказанное, получим следующее выражение функции цели оптимальной работы селекционного зерноуборочного комбайна:

$$
\begin{aligned}
B_{\mathrm{\kappa}}=\left(\left(\left(V_{\text {б }} * \gamma_{\mathrm{в}}\right.\right.\right. & \left.\left.* K_{\text {зап }}\right) *\left\lfloor\frac{\left(t_{\mathrm{cм}}-t_{\text {отл }}-t_{\text {то }}\right) * k}{\left(t_{\text {бз }}+t_{\text {пов }}+t_{\text {разг }}\right)}\right]\right) \\
& *\left(\left\lceil\frac{V_{\Sigma} *\left(t_{\text {бз }}+t_{\text {пов }}+t_{\text {разг }}\right)}{\left(t_{\mathrm{cm}} * k-t_{\text {отл }}-t_{\text {то }}\right) * V_{\text {б }} * \gamma_{\text {в }} * K_{\text {зап }} * T}\right\rceil\right) * T, \mathrm{~T}
\end{aligned}
$$

Применительно к работе транспортных средств уравнение валового объёма работ будет иметь вид:

$$
B_{\mathrm{T}}=\left(Q_{\mathrm{K}} * \frac{t_{\mathrm{cm}}^{\text {дा }}}{t_{\mathrm{LT}}}\right) *\left\lceil\frac{V_{\Sigma}}{Q_{\text {с. } \mathrm{T}}^{\mathrm{T}} * \mathrm{~T}}\right\rceil * T, \mathrm{~T}
$$

$Q_{\text {с.п }}^{\mathrm{T}}$, т, определяется: $Q_{\text {к }}, \mathrm{T}-$ цикловой вместимостью кузова транспортного средства, определяющейся из суммарно вмещающегося объёма упаковок $V_{\text {сум.уп }}, \mathrm{m}^{3}$, их коэффициентов использования вместимости $\eta$, плотности засыпанного материала $\gamma_{\text {в }}$, т/м ${ }^{3}$; количеством циклов в смену $n_{\text {цт }}$, характеризующимся отношением $t_{\text {см }}^{\text {дт }}$, , ко времени цикла $t_{\text {цт }}$, ч, складывающемуся из

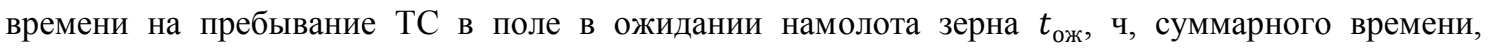

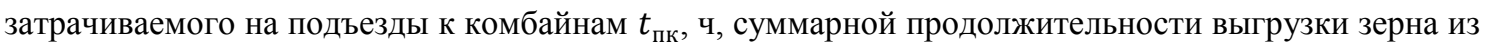
бункеров $t_{\text {выг }}$, ч, времени движения транспортного средства от комбайна к току с грузом $t_{\text {ас }}$, ч, и без груза $t_{\text {аб }}$, ч, времени, затрачиваемого ТС на взвешивание, оформление документов $t_{\text {орг }}$, ч, и времени, затрачиваемого ТС на разгрузку $t_{\text {разг }}$, ч.

Для определения требуемого количества транспортных средств $X_{\text {т }}$ (3) воспользуемся пропорцией сменных количеств циклов (6), учитывая при этом, что время цикла транспортного средства может быть больше цикла комбайна, для чего требуется определить их округлённое 
соотношение для бесперебойной работы комбайна. Все остальные показатели работы транспортных средств рассчитываются аналогично показателям работы зерноуборочного комбайна. Учитывая вышесказанное, получим следующее уравнение валового объёма работ оптимальной работы транспортного средства:

$$
\begin{aligned}
B_{\mathrm{c}}=\left(V_{\text {сум.уп }} * \eta\right. & * \gamma_{\mathrm{B}} *\left(\frac{\left(t_{\text {см }}-t_{\text {отл }}-t_{\text {то }}\right) * k}{t_{\text {ож }}+t_{\text {пк }}+t_{\text {выг }}+t_{\text {ас }}+t_{\text {аб }}+t_{\text {орг }}+t_{\text {разг }}}\right) \\
& *\left(\left[\frac{t_{\text {цт }}}{t_{\text {цк }}}\right] *\left\lceil\frac{V_{\Sigma} * t_{\text {цт }}}{t_{\text {см }}^{\text {дт }} * V_{\text {сум.уп }} * \gamma_{\text {в }} * \eta * T}\right]\right) * T, \mathrm{~T}
\end{aligned}
$$

Применительно к работе сушильных установок, после первичного преобразования уравнение валового объёма работ будет выглядеть следующим образом:

$$
B_{\mathrm{c}}=\left(W_{\text {экс }}^{\mathrm{u}} * t_{\mathrm{cm}}^{\mathrm{дc}}\right) *\left(\left\lceil\frac{V_{\Sigma}}{Q_{\mathrm{c.} . \Pi}^{\mathrm{c}} * T}\right\rceil\right) * T, \mathrm{~T}
$$

$W_{\text {экс }}^{\text {, }}$ т/ч - эксплуатационная производительность сушильного агрегата, определяющаяся

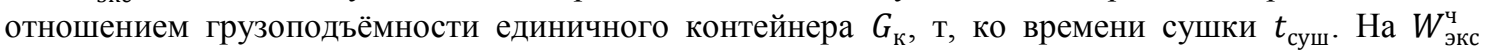
также влияют понижающие коэффициенты: коэффициент, учитывающий изменение производительности сушилки от вида культуры $K_{\mathrm{K}}=1$, учитывающий назначение зерна $K_{\mathrm{c}}=1$, учитывающий процент снижения влажности $K_{\text {в }}=1$, учитывающий техническую надёжность сушильного агрегата $K_{\mathrm{T}}=0,95$, а также от $\gamma_{\mathrm{B}}$.

Учитывая вышесказанное, получим следующее уравнение оптимальной работы зерносушильной установки:

$$
B_{\mathrm{c}}=\left(\frac{G_{\mathrm{\kappa}}}{t_{\text {суш }}} * K K_{\kappa} * K_{\mathrm{c}} * K_{\mathrm{B}} * K_{\mathrm{T}} * \gamma_{\mathrm{B}} * t_{\mathrm{cm}}^{\text {дс }}\right) *\left(\left\lceil\frac{V_{\Sigma}}{Q_{\mathrm{c}}^{\mathrm{c}} * T}\right\rceil\right) * T, \mathrm{~T}
$$

Одним из способов увеличения высоты слоя является реверс агента сушки. Действительно, способ сушки при непрерывной односторонней продувке материала агентом сушки не является оптимальным. Оболочка зерновок, содержащая слабосвязанную влагу быстро обезвоживается, и фронт сушки углубляется в ядро, которое характеризуется прочной связью вещества с влагой. При этом возрастает энергия на испарение влаги, повышается температура зерновки и снижается скорость сушки.

Распространение сушки в неподвижном слое объясняется предотвращением механических повреждений, а применение сравнительно невысоких температур сушильного агента способствует послеуборочному дозреванию и перераспределению питательных веществ в зерне с потоком влаги в жидкой фазе, что приводит к улучшению его посевных качеств. Однако скорость такой сушки сравнительно мала и при сушке слоя семян в несколько метров атмосферный воздух, используемый в качестве сушильного агента для поддержания безопасного режима сушки подогревают всего лишь на 3 - 7 град. В основу безопасного режима односторонней сушки зерна принимают его предельно допустимую температуру, на основе которой определяют температуру агента сушки. Предельная температура нагрева зерна ограничивается сохранением его всхожести.

Влияние температуры на качество семян пшеницы, ячменя, гороха и подсолнечника изучали в процессе сушки их в лабораторных установках [2]. Наблюдения вели, главным образом, за нижним слоем семян, наиболее подверженным воздействию повышенной температуры, а для контроля - также за верхним и средним слоями. Экспериментальные данные показывают, что в диапазоне начальной влажности зерна 24 - 30 \% его всхожесть снижается на $2 \%$ при превышении на 1 град. диапазона температуры его нагрева в $40-44$ град. Это подтверждают другие исследования в отношении допустимой температуры агента сушки в привязке к предельно допустимой температуре нагрева зерна. Так, при сушке пшеницы начальной влажностью 25,5 \% всхожесть сохранялась на исходном уровне, если температура подаваемого воздуха была не выше 40 град., влажностью 22,4\% - 45 град. и влажностью $18,8 \%$ - 51 град. С повышением температуры воздуха сверх указанных значений всхожесть падала особенно значительно при большей влажности зерна и температуре воздуха.

Были проведены исследования реверсивной сушки семян пшеницы с определением показателей процесса времени сушки, температуры зерна после сушки [3]. На рисунке 2 представлены кривые сушки $(1 ; 2)$ и нагрева зерна $(3 ; 4)$ в слое $\mathrm{h}=0,35$ м при реверсе $(1 ; 3)$ и 
контроле (2; 4). Из полученных результатов следует: длительность сушки с применением реверса теплоносителя на 14 - 15 \% ниже, чем при односторонней продувке, при этом температура зерна после сушки в нижнем слое при реверсе была на 1,5-2 град. ниже, чем при односторонней продувке, что позволит дополнительно снизить время сушки. Реверс сушки осуществляли ручным перебросом насадки с одного патрубка на противоположный.

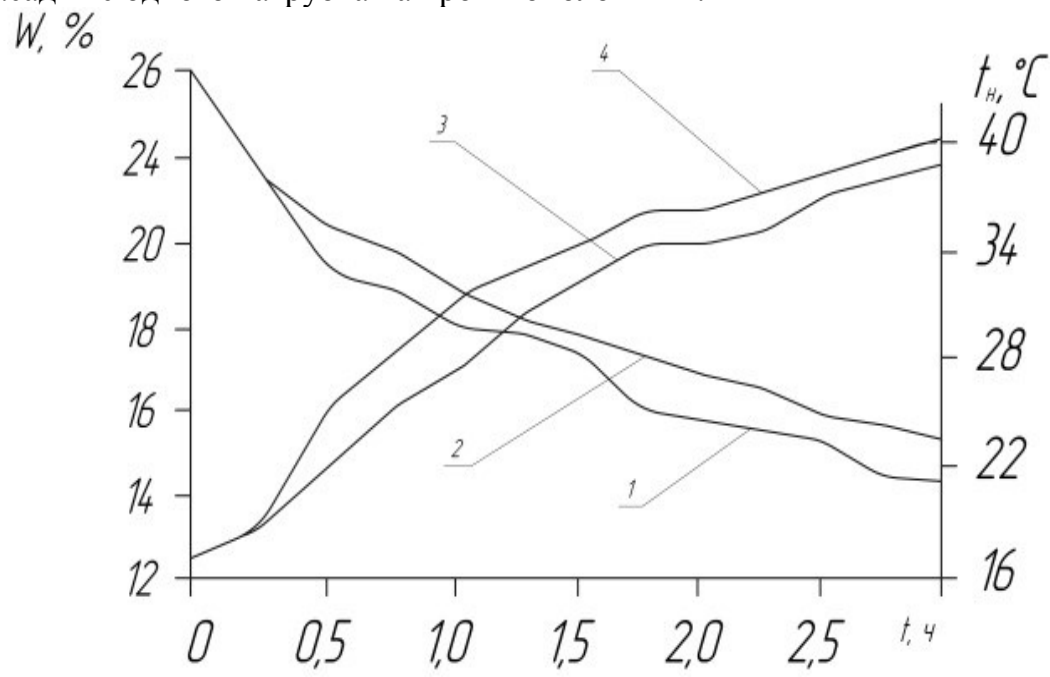

Рисунок 2 - Кривые сушки и нагрева зерна пшеницы в слое $\mathrm{h}=0,35$ м

Поскольку из полученных результатов следует, что реверс агента сушки снижает время сушки

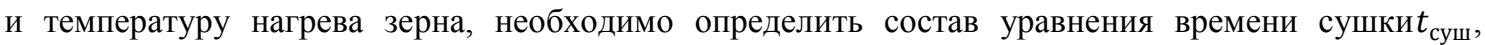
разветвив математическую модель в её определении. Так, для сушки семян без учёта реверса время сушки будет определяться по классической зависимости:

$$
t_{\text {суш }}=\frac{\left(U_{\mathrm{H}}-U_{\mathrm{\kappa}}\right) * r * H}{\alpha *\left(t_{\mathrm{aг}}-\theta_{\mathrm{cp}}\right) * f * \eta * h_{n}}, \text { ч, }
$$

где $U_{\mathrm{H}}, U_{\mathrm{\kappa}}$ - начальное и конечное влагосодержание семян, кг вл./кг сух. м; $\mathrm{r}$ - теплота парообразования влаги, кДж/кг, $r \approx 2730$ кДж/кг; Н - высота слоя семян, м; $\alpha$ - коэффициент теплоотдачи, Вт/( $\left.{ }^{2} \cdot{ }^{\circ} \mathrm{C}\right), \alpha \approx 17,5 \frac{\mathrm{Bт}}{\mathrm{m}^{2} \cdot{ }^{\circ} \mathrm{C}} ; t_{\mathrm{ar}}-$ температура агента сушки, ${ }^{\circ} \mathrm{C} ; t_{\mathrm{ar}}=40{ }^{\circ} \mathrm{C} ; \theta_{\mathrm{cp}}-$ начальная средняя температура семян, ${ }^{\circ} \mathrm{C} ; \theta_{\text {ср }} \approx 25^{\circ} \mathrm{C} ; f$ - удельная поверхность семян, ${ }^{2} / \kappa г$; $f \approx 3 \mathrm{~m}^{2} /$ кг; $\eta$ - доля теплоты, отведённая на испарение влаги [4].

Время сушки с учётом реверсирования представляет собой полином второго порядка, своим видом обусловленный более ранними исследованиями и определяющийся планом эксперимента Бокса-Бенкена теоретически через косвенную связь количества переворотов контейнера и конечную температуру зерна, входящей в параметр $\eta[5]$.

$$
y_{\text {расч }}=4,54+3,4 x_{1}-0,02 x_{2}-0,86 x_{3}+0,87 x_{1}^{2}-0,03 x_{3}^{2}, ч
$$

где $x_{1}$ - начальная влажность зерна, $\%, x_{2}$ - количество переворотов контейнера $\mathrm{n}$, ед, $x_{3}$ - момент влажности его реверса, \%, своим выбором обусловленный результатами более ранних исследований [2].

Диапазоны варьирования и кодированные значения факторов приведены в таблице 1, значения откликов приведены в таблице 2.

Таблица 1 - Диапазоны варьирования и кодированные значения факторов

\begin{tabular}{|c|c|c|c|}
\hline Факторы & $\begin{array}{c}w_{0}, \% \text { - начальная } \\
\text { влажность зерна }\end{array}$ & $\begin{array}{c}n, \text { ед. }- \text { количество } \\
\text { переворотов } \\
\text { контейнера }\end{array}$ & $\begin{array}{c}w_{\text {рев }}, \% \text { - момент } \\
\text { влажнсти переворота } \\
\text { контейнера }\end{array}$ \\
\hline Диапазон варьирования & $20 \ldots 25 \ldots 30$ & $1 \ldots 3 \ldots 5$ & $14 \ldots 16 \ldots 18$ \\
\hline $\begin{array}{c}\text { Кодированные значения } \\
\text { факторов }\end{array}$ & $-1 \ldots 0 \ldots+1$ & $-1 \ldots 0 \ldots+1$ & $-1 \ldots 0 \ldots+1$ \\
\hline
\end{tabular}


Таблица 2 - Трёхфакторный трёхуровневый план эксперимента Бокса-Бенкена

\begin{tabular}{|c|c|c|c|c|c|c|c|c|c|c|c|c|}
\hline \multirow{2}{*}{$№$} & \multicolumn{10}{c|}{ Матрица плана } & \multicolumn{3}{c|}{$\begin{array}{c}\text { Время сушки до } \\
\text { кондиционной влажности }\end{array}$} \\
\cline { 2 - 14 } & $x_{0}$ & $x_{1}$ & $x_{2}$ & $x_{3}$ & $x_{1} x_{2}$ & $x_{1} x_{3}$ & $x_{2} x_{3}$ & $x_{1}^{2}$ & $x_{2}^{2}$ & $x_{3}^{2}$ & $y_{\text {эксn }}$ & $y_{\text {расч }}$ \\
\hline 1 & 1 & 1 & 1 & 0 & 1 & 0 & 0 & 1 & 1 & 0 & 8,79 & 8,79 \\
\hline 2 & 1 & 1 & -1 & 0 & -1 & 0 & 0 & 1 & 1 & 0 & 8,83 & 8,82 \\
\hline 3 & 1 & -1 & 1 & 0 & -1 & 0 & 0 & 1 & 1 & 0 & 2 & 1,99 \\
\hline 4 & 1 & -1 & -1 & 0 & 1 & 0 & 0 & 1 & 1 & 0 & 2,04 & 2,03 \\
\hline 5 & 1 & 0 & 0 & 0 & 0 & 0 & 0 & 0 & 0 & 0 & 4,54 & 4,54 \\
\hline 6 & 1 & 1 & 0 & 1 & 0 & 1 & 0 & 1 & 0 & 1 & 7,92 & 7,92 \\
\hline 7 & 1 & 1 & 0 & -1 & 0 & -1 & 0 & 1 & 0 & 1 & 9,63 & 9,63 \\
\hline 8 & 1 & -1 & 0 & 1 & 0 & -1 & 0 & 1 & 0 & 1 & 1,13 & 1,13 \\
\hline 9 & 1 & -1 & 0 & -1 & 0 & 1 & 0 & 1 & 0 & 1 & 2,84 & 2,84 \\
\hline 10 & 1 & 0 & 0 & 0 & 0 & 0 & 0 & 0 & 0 & 0 & 4,54 & 4,54 \\
\hline 11 & 1 & 0 & 1 & 1 & 0 & 0 & 1 & 0 & 1 & 1 & 3,63 & 3,63 \\
\hline 12 & 1 & 0 & 1 & -1 & 0 & 0 & -1 & 0 & 1 & 1 & 5,18 & 5,17 \\
\hline 13 & 1 & 0 & -1 & 1 & 0 & 0 & -1 & 0 & 1 & 1 & 3,67 & 3,67 \\
\hline 14 & 1 & 0 & -1 & -1 & 0 & 0 & 1 & 0 & 1 & 1 & 5,21 & 5,21 \\
\hline 15 & 1 & 0 & 0 & 0 & 0 & 0 & 0 & 0 & 0 & 0 & 4,52 & 4,54 \\
\hline
\end{tabular}

Получены коэффициенты регрессии: $b_{0}=4,54 ; b_{1}=3,4 ; b_{2}=-0,02 ; b_{3}=-0,86 ; b_{12}=-0,002$; $b_{13}=0,003 ; b_{23}=-0,0005 ; b_{11}=0,87 ; b_{22}=0,003 ; b_{33}=-0,03$.

Значимость коэффициентов регрессии по доверительному интервалу критерия Стьюдента $t=2,776: \Delta b_{0}=0,0179,\left|b_{0}\right|>\Delta b_{0} \Rightarrow b_{0}$ - значимый коэффициент; $\Delta b_{i}=0,01,\left|b_{1,2,3}\right|>\Delta b_{0}$ $\Rightarrow b_{1,2,3}$ - значимые коэффициенты; $\Delta b_{i l}=0,015,\left|b_{12,13,23}\right|<\Delta b_{0} \Rightarrow b_{12,13,23}$ - не значимые коэффициенты; $\Delta b_{i i}=0,005,\left|b_{11,33}\right|>\Delta b_{0},\left|b_{22}\right|<\Delta b_{0} \Rightarrow b_{11,33}$ - значимые коэффициенты, $b_{22}-$ не значимый коэффициент.

Адекватность уравнения регрессии по критерию Фишера: $F_{\text {расч }}=0,16, F_{\text {расч }}<1$ уравнение адекватно на всех уровнях значимости.

Таким способом при сушке столба 600 мм с $25 \%$ до 14 \% были получены значения 5 часов 44 минуты для сушки в стационарном слое и минимально 5 часов 10 минут для сушки с реверсированием, показавшее снижение времени сушки на $10 \%$, что близко к проведённым ранее исследованиям [3].

В ходе экспериментальных исследований изучались временные показатели транспортнотехнологических процессов с применением мягкой тары на примере уборки 7 га овса сорта “Яков" в ФГБНУ «Рязанский НИИСХ». По результатам, которые представлены в таблице 3, курсивом выделены операции, более 50 \%, на которые повлияет контейнеризация.

Отмечено, что из всех транспортно-перегрузочных работ перегрузочные работы при переходе с транспортировки на первичную обработку зерна имели 26\%-ную вариативность по времени.

Таблица 3 - Временные показатели транспортно-технологического процесса заготовки семян

\begin{tabular}{|c|c|c|}
\hline $\begin{array}{c}\text { Уборка. Время цикла - } \\
0,46 \text { ч: }\end{array}$ & $\begin{array}{c}\text { Транспортировка. } \\
\text { Время цикла }-0,84 \text { ч }-1,03 \text { ч: }\end{array}$ & $\begin{array}{l}\text { Послеуборочная обработка. Время } \\
\text { иикла - } 103,63 \text { ч (Валовый сбор } \\
33180 \text { кг, грузоподъёмность } \\
\text { мешкотары - } 35 \text { кг.): }\end{array}$ \\
\hline $\begin{array}{l}\text { Время поворотов - } \\
0,11 \text { ч; } \\
\text { Время внеплановых } \\
\text { остановок - } 0,03 \text { ч; } \\
\text { Время } \\
\text { комбайнирования - } \\
\text { 0,32 ч. }\end{array}$ & $\begin{array}{l}\text { Время разгрузки бункера - 0,02 ч; } \\
\text { Время движения туда-обратно - 0,15 ч; } \\
\text { Время взвешивания и оформления } \\
\text { документов - 0,07 ч; } \\
\text { Время маневрирования на токе -0,04 ч; } \\
\text { Время разгрузки материала - 0,56 ч- } \\
0,75 \text { ч. }\end{array}$ & $\begin{array}{l}\text { Сушка - } 96 \text { ч; } \\
\text { Упаковка - 2,03 ч; } \\
\text { Перемещение - 3,76 ч; } \\
\text { Перекладывание - 1,84 ч. }\end{array}$ \\
\hline
\end{tabular}


С разработанным контейнером, представленным на рисунке 3 , проводились испытания на операцию «подъём, перемещение и опускание» крюковым манипулятором.

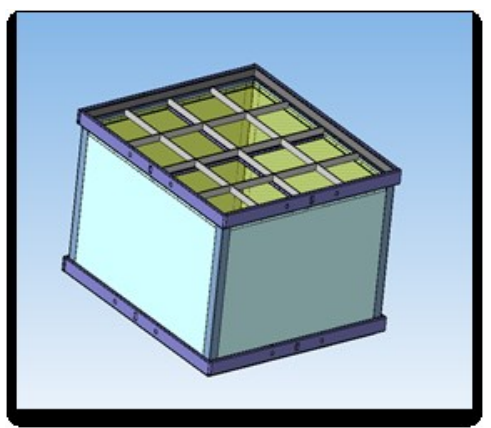

Рисунок 3 - Сушильно-транспортный контейнер

Время её выполнения составляет 39 сек. Дополнительно, разрабатываемый контейнер исследовался на выполнение операции «упаковка». Время, затрачиваемое на открывание и закрывание крышки составило 18 сек. Комплектование 14 мешков, грузоподъёмностью 35 кг с эквивалентной грузоподъёмностью 0,5 т, с операцией завязывания и штабелирования заняло 4 мин 48 сек.

Результаты и их обсуждение. Описанная функция (1) в графическом виде представляет собой кривую, отражающую изменение эксплуатационных затрат в зависимости от величины валового сбора, который убирался комбайнами второго класса с применением классической и контейнерной технологии и представлена на рисунке 4.

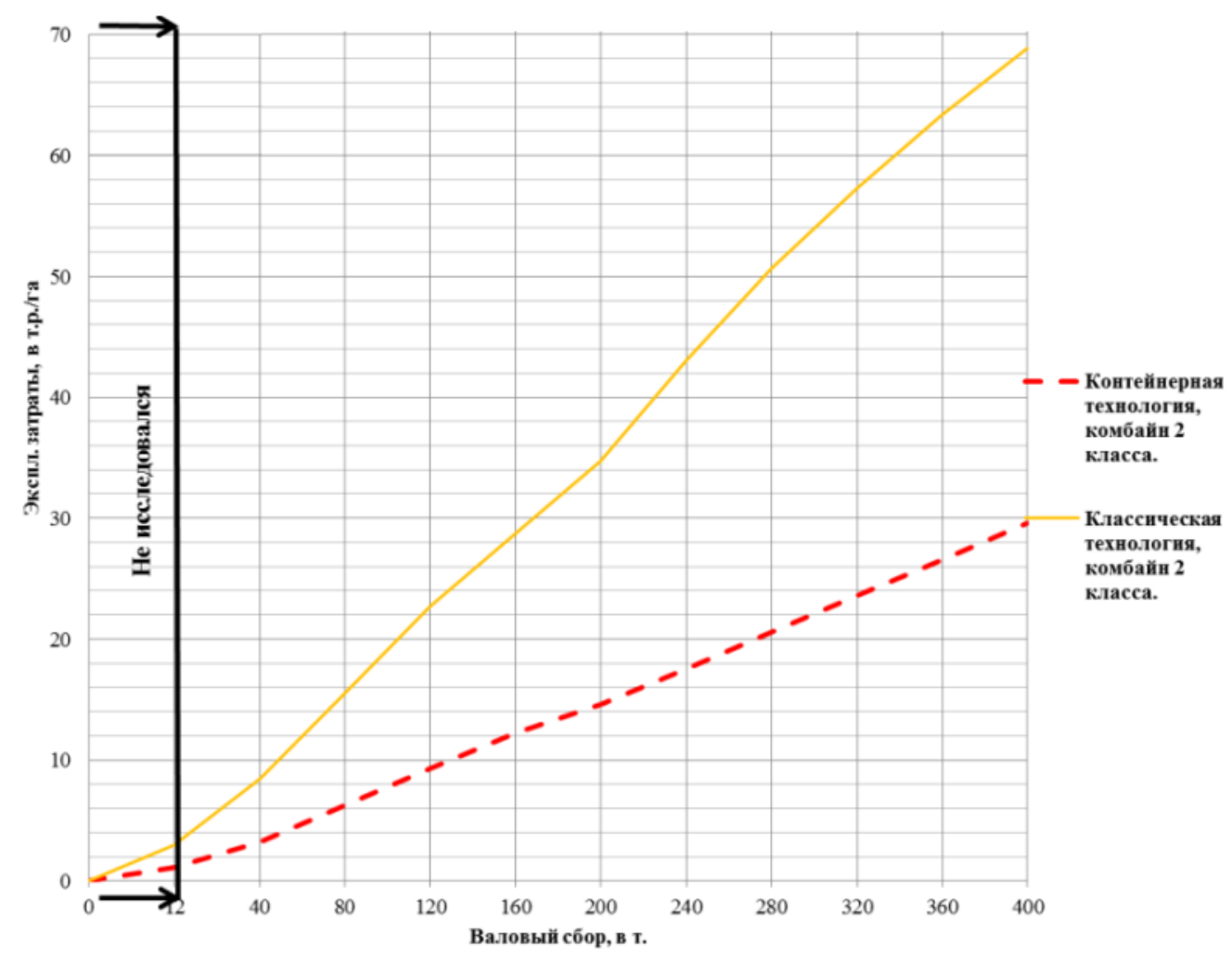

Рисунок 4 - Изменение затрат (тыс. руб/га) в зависимости от валового сбора (т) при убочно-транспортном процессе при использовании комбайна 2 класса в классической (сплош.) и контейнерной (штрих.) технологии 
Точка функции и соответствующая технология уборки, показавшая наименьшие затраты при уборке различных объёмов зерна и является целевой. Важно отметить, что затраты на уборку менее 12 тонн не исследовались и с нулём соединены условно, поскольку для уборки данной области объёмов необходима иная технология уборки.

Заключение. Суммарный экономический эффект: от внедрения сушильно-транспортных контейнеров грузоподъёмностью 0,5 т вместо мягкой упаковки, при валовом сборе зерна до 400 т, стоимости контейнера 79,2 тыс. руб/га и мягкой упаковки в 2 тыс. руб/га соответственно, за счёт снижения затрат, в среднем на 58,8 \%, составил от 5,21 тыс. руб./га до 39,28 тыс. руб/га. Согласно расчётам рассматриваемый проект окупается через 2 года и 8 месяцев.

\section{Список литературы}

1. Крюков М.Л., Иванов М.В., Степанов К.А. Обоснование параметров контейнеризации процессов уборки, переработки и хранения семян на III и IV этапах селекции и первичного семеноводства // Инновации в сельском хозяйстве. М.: Федеральный научный агроинженерный центр ВИМ, 2018. - № 3 (28). - С. 508 - 514.

2. Уколов В.С. Сушка семян в камерных сушилках с реверсивной подачей воздуха // Теория и техника сушки зерна: труды научной конференции 15-17 апреля 1969 года. - М: ВНИИЗ, 1969. С. $181-190$.

3. Павлов С.А., Голубкович А.В. К вопросу эффективности реверсивной сушки зерна // Труды международной научно-технической конференции «Энергообеспечение и энергосбережение в сельском хозяйстве». - М.: Всероссийский научно-исследовательский институт электрификации сельского хозяйства, 2012. - С. $148-152$.

4. Патент РФ № 2578920, МПК F25B3/06. Способ реверсивной сушки семян / Голубкович А.В. (RU), Павлов C.A. (RU), Марин Р.A. (RU), Дадыко А.Н. (RU).

5. Захахатнов В.Г., Кашин П.В., Коковин Г.Д. Планирование эксперимента по исследованию времени сушки зерна в шахтной сушилке // АПК России. - 2018. - № 3 (25). - С. 400 - 404.

\section{References}

1. Krjukov M.L., Ivanov M.V., Stepanov K.A. Obosnovanie parametrov kontejnerizacii processov uborki, pererabotki i hranenija semjan na III i IV jetapah selekcii i pervichnogo semenovodstva // Innovacii v sel'skom hozjajstve. M.: Federal'nyj nauchnyj agroinzhenernyj centr VIM, 2018. - № 3 (28). - S. $508-514$.

2. Ukolov V.S. Sushka semjan v kamernyh sushilkah s reversivnoj podachej vozduha // Teorija i tehnika sushki zerna: trudy nauchnoj konferencii 15-17 aprelja 1969 goda. - M: VNIIZ, 1969. - S. 181 190.

3. Pavlov S.A., Golubkovich A.V. K voprosu jeffektivnosti reversivnoj sushki zerna // Trudy mezhdunarodnoj nauchno-tehnicheskoj konferencii «Jenergoobespechenie i jenergosberezhenie V sel'skom hozjajstve». - M.: Vserossijskij nauchno-issledovatel'skij institut jelektrifikacii sel'skogo hozjajstva, 2012. - S. $148-152$.

4. Patent RF № 2578920, MPK F25B3/06. Sposob reversivnoj sushki semjan / Golubkovich A.V. (RU), Pavlov S.A. (RU), Marin R.A. (RU), Dadyko A.N. (RU).

5. Zahahatnov V.G., Kashin P.V., Kokovin G.D. Planirovanie jeksperimenta po issledovaniju vremeni sushki zerna v shahtnoj sushilke // APK Rossii. - 2018. - № 3 (25). - S. 400 - 404.

\section{Сведения об авторах}

Принадлежность к организации

Степанов Кирилл Александрович - инженер Федерального государственного бюджетного научного учреждения «Федеральный научный агроинженерный центр ВИМ», Россия, г. Москва, еmail: 89999878895@mail.ru.

Иванов Максим Викторович - инженер Федерального государственного бюджетного научного учреждения «Федеральный научный агроинженерный центр ВИМ», Россия, г. Москва, e-mail: maks.ivanov.1992@mail.ru.

Крюков Михаил Львович - ведущий специалист Федерального государственного бюджетного научного учреждения «Федеральный научный агроинженерный центр ВИМ», Россия, г. Москва, еmail: krumil52@mail.ru. 


\title{
Author credentials
}

Affiliations

Stepanov Kirill - engineer of Federal State Budgetary Scientific Institution "Federal Scientific Agroengineering Center VIM", Russia, Moscow, e-mail: 89999878895@mail.ru.

Ivanov Maxim - engineer of Federal State Budgetary Scientific Institution "Federal Scientific Agroengineering Center VIM”, Russia, Moscow, e-mail: maks.ivanov.1992@mail.ru.

Kryukov Michael - leading specialist of Federal State Budgetary Scientific Institution "Federal Scientific Agroengineering Center VIM”, Russia, Moscow, e-mail: krumil52@mail.ru.

Поступила в редакцию (Received): 20.07.2020 Принята к публикации (Accepted): 21.08.2020

УДК 635.21

DOI: $10.35887 / 2305-2538-2020-4-26-33$

\section{РЕЗУЛЬТАТЫ ЭКСПЕРИМЕНТАЛЬНЫХ ИССЛЕДОВАНИЙ ВЫСАЖИВАЮЩЕГО АППАРАТА МИНИ КАРТОФЕЛЕСАЖАЛКИ}

\author{
${ }^{1}$ Бочкарев Антон Сергеевич \\ ${ }^{1}$ Ларюшин Николай Петрович \\ ${ }^{1}$ Кухарев Олег Николаевич \\ ${ }^{1}$ ФББОУ ВО «Пензенский государственный аграрный университет»
}

Реферат. Основным фактором, влияющим на урожайность картофеля, является площадь питания, определяемая равномерностью распределения клубней по дну бороздьл при посадке. Соблюдение равномерности распределения семенного материала является приоритетной задачей при конструировании сажалок. Обоснование оптимальных значений высаживающего аппарата с ограничителем раскатывания клубней по дну борозды осуществили с помощьюю многофакторного эксперимента. За критерий оптимизации процесса высадки принимали равномерность распределения клубней по дну борозды после посадки, под которой понимали процент высаженных клубней, фактическое расстояние между которыми не могло отличаться больше, чем в 0,8 - 1,2 раза от установленного на высаживающем аппарате. На основе априорного ранжирования были отобраны 8 факторов, которые в значительной мере влияют на эту характеристику. Определень оптимальные параметры: усилие прижатия катка к дну борозды - 14 - 26 H, диаметр катка - 115 - 155 мм, показатель кинематического режима - 0, - 1,1, которые обеспечивают равномерность распределения клубней по дну борозды после посадки не менее 86 \%.. Экспериментальный высаживающий аппарат исследован на почвенном канале. В результате эксперимента получень зависимости равномерности распределения клубней по дну борозды после посадки от усилия прижатия катка к дну борозды, диаметра катка, кинематического режима. Установлено, что при использовании экспериментального высаживающего аппарата с ограничителем скорости клубней с данными конструктивными параметрами повысится урожайность производимой культуры $и$ снизятся затрать на её производство.

Ключевые слова: картофель, мини картофелесажалка, многофакторный эксперимент, равномерность распределения клубней.

\section{EXPERIMENTAL RESEARCH RESULTS PLANTING APPARATUS AT MINI POTATO PLANTER}

${ }^{I}$ FSBEI HE "Penza State Agrarian University”

\author{
${ }^{1}$ Bochkarev Anton \\ ${ }^{1}$ Laryushin Nikolay \\ ${ }^{1}$ Kuharev Oleg
}

Abstract. The main factor affecting the yield of potatoes is the feeding area, determined by the uniform distribution of tubers along the bottom of the furrow during planting. The rationale for the 
optimal values of the planting apparatus with a limiter for rolling tubers along the bottom of the furrow was carried out using a multivariate experiment. The uniformity of the distribution of tubers along the bottom of the furrow after planting, which was understood as the \% of tubers planted, the actual distance between which could not differ more than 0,8 - 1,2 times from that installed on the planting apparatus, was taken as an optimization criterion. 8 factors that significantly affect this characteristic were selected based on a priori ranking. Optimum parameters: the pressing force of the skating rink to the bottom of the furrow is $14-26 \mathrm{~N}$, the diameter of the skating rink is $115-155 \mathrm{~mm}$, the kinematic index is 0, - 1.1, which ensure a uniform distribution of tubers along the bottom of the furrow after planting at least $86 \%$. were determined. The experimental planting apparatus was investigated on the soil channel. As a result of the experiment, the dependences of the uniform distribution of tubers along the bottom of the furrow after planting on the pressing force of the roller to the bottom of the furrow, the diameter of the roller, and the kinematic mode are obtained. It was established that when using an experimental planting apparatus with a tuber speed limiter with these design parameters, the yield of the produced crop will increase and the cost of its production will decrease.

Keywords: potato, mini potato planter, multivariate experiment, uniform distribution of tubers.

Введение. Посадка является наиболее значимой операцией в технологии производства, как для картофеля, так и для других сельскохозяйственных культур. На урожай особенно оказывают влияние климатические условия, среда обитания где произрастает культура, а также качественные показатели выполнения посадочных работ. Всё вышеперечисленное позволяет снизить затраты труда и уменьшить себестоимость получаемой продукции.

Высаживающие аппараты мини картофелесажалок, не в полной мере соответствуют агротехническим требованиям. Основным фактором, определяющим урожайность картофеля, считается равномерность распределения клубней по дну борозды. Именно этот фактор отвечает за формирование площади питания для картофеля. В связи с этим конструирование высаживающего аппарата картофелесажалки таким образом, чтобы улучшались качественные показатели посадки семян (равномерность распределения семян по длине рядка, глубина их заделки) является актуальной. В ФГБОУ ВО Пензенский ГАУ с этой целью разработан, изготовлен и испытан высаживающий аппарат с ограничителем раскатывания клубней. На конструкцию данного устройства подана заявка на патент.

Материалы и методы. Для улучшения качественных показателей посадки картофеля в ФГБОУ ВО Пензенский ГАУ разработан высаживающий аппарат с ограничителем раскатывания клубней картофеля по дну борозды после посадки, изображенный на рисунке 1.

При использовании экспериментального высаживающего аппарата получен следующий результат: исключено раскатывание клубней картофеля, при этом происходит уплотнение семян картофеля на дне борозды, кроме этого обеспечивается равномерная глубина заделки клубней картофеля, а также равномерное распределение их по дну борозды. Всё это в свою очередь даёт равномерное прорастание семян. В итоге все перечисленное выше улучшает качественные показатели посадки семян картофеля. Это в свою очередь приводит к увеличению урожайности возделываемой культуры.

Для экспериментов по определению равномерности распределения клубней картофеля по длине рядка с высаживающим аппаратом, с ограничителем раскатывания клубней по дну борозды после посадки использовали лабораторную установку, показанную на рисунке 2.

Эта установка включала в себя: канал в металлическом основании, заполненный почвой 3 с установленной в нем подвижной тележкой с приводом 12 и навеской 8. Экспериментальная установка (высаживающий аппарат с ограничителем раскатывания клубней) помещена на навеску 8 тележки 12. Приближает экспериментальные условия к реальным установка сошника 2 картофелесажалки на навеске 8 приводной тележки 12 с минимальным зазором между нижней кромкой сошника-бороздообразователя 2 и поверхностью посадки. Для поверхности посадки создан ровный участок почвы. Приводную тележку 12 через редуктор 4, цепную передачу, систему полиспастов и гибкий трос 5 приводил в движение электродвигатель 7. Последний с помощью цепных передач через многоступенчатый редуктор 6 приводил в движение ложечноэлеваторный транспортер. Включение и отключение установки осуществляет оператор, используя пульт 13. 


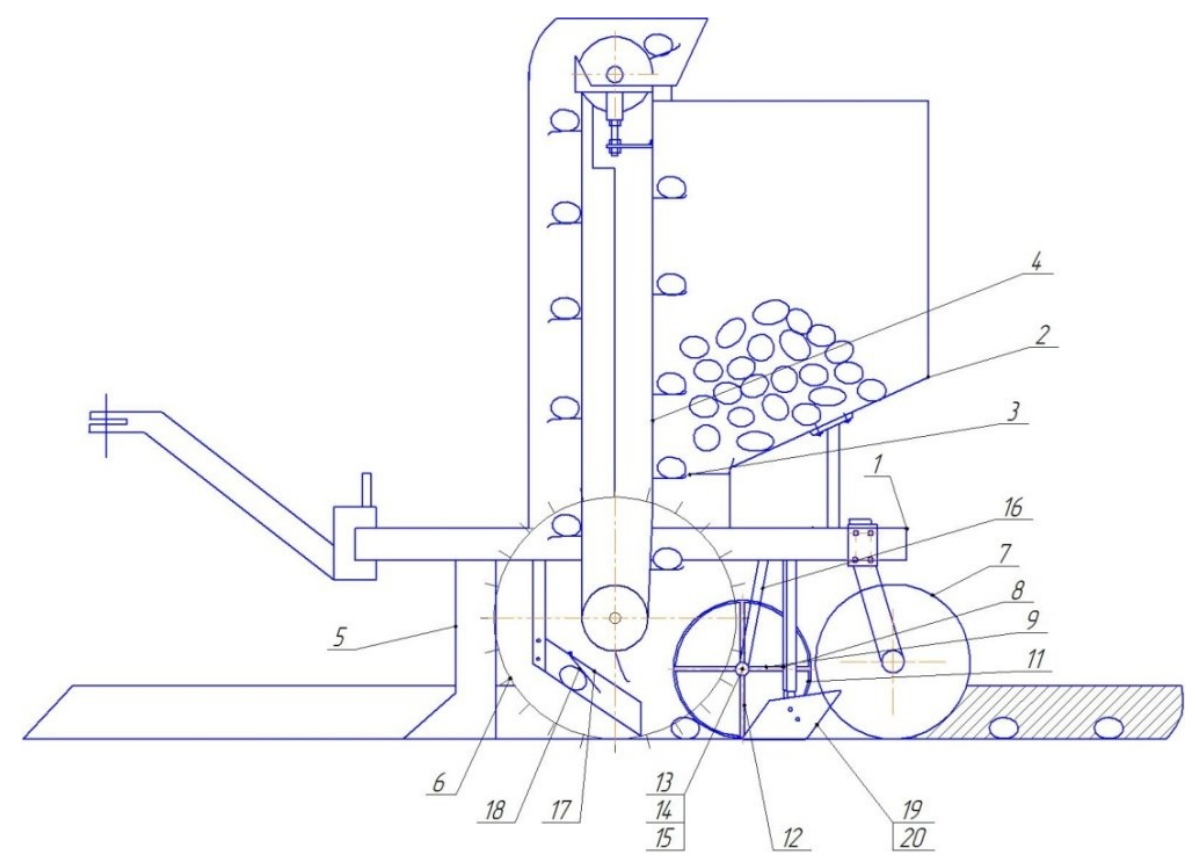

1 - рама; 2 - бункер; ковш-питатель; 4 -высаживающий аппарат; 5 - сошник-бороздообразователь; 6 -опорное колесо; 7 - бороздозакрыватель; 8 - ограничитель раскатывания клубней; 9 - каток;

10 - решетчатая поверхность цилиндра; 11 - обод; 12 - спица; 13 - ступица; 14 - подшипник скольжения; 15 - ось катка; 16 - пружинная стойка; 17 - желоб; 18 - ориентирующее устройство; 19, 20 - лапы-отвальчики.

Рисунок 1 - Схема картофелесажалки с высаживающим аппаратом с ограничителем раскатывания клубней:

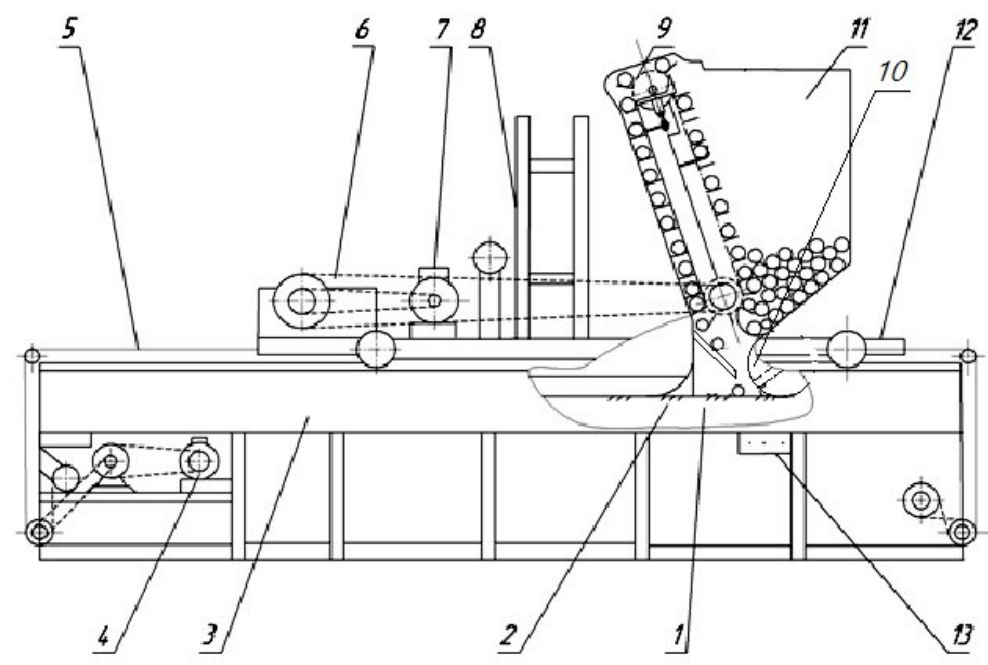

1 - почва; 2 - сошник-бороздообразователь; 3 - канал почвенный; 4 - редуктор; 5 - трос;

6 - цепная передача; 7 - мотор редуктор; 8- рама; 9 - цепочно-ложечный высаживающий аппарат; 10 - ограничитель раскатывания клубней; 11 -бункер; 12 -приводная тележка; 13 - пульт управления

Рисунок 2 - Общий вид лабораторной установки для изучения оптимальных конструктивно-кинематических параметров высаживающего аппарата с ограничителем раскатывания клубней по дну борозды 
Результаты и их обсуждение. За критерий оптимизации процесса высадки принимали \% высаженных клубней, фактическое расстояние между которыми отличалось не более, чем в 0,8 1,2 раза от установленного на высаживающем аппарате, характеризующего равномерность распределения клубней по дну борозды после посадки R.

Априорным ранжированием выбрали 8 основных факторов, которые в наибольшей степени влияют на равномерность распределения клубней по дну борозды после посадки. В начале зависимость факторов рассматривали линейно в программе Statistica 6.0, после чего был сделан вывод, что линейная зависимость неадекватно описывает данные. Стоит так же отметить, что экспериментальные исследования не позволяют учесть все факторы, определяющие равномерность распределения, поэтому были выбраны наиболее важные, по мнению авторов, на основании предварительно полученной информации.

Методика исследования предполагает отсеивающий эксперимент, для проведения которого использовали матрицу, учитывающую первоначально выделенные факторы путем случайного смешивания двух полуреплик. Обработка результатов отсеивающего эксперимента с помощью программы Statistica 6.0, выявилаосновные факторы, которые оказывают наибольшее влияние на равномерность распределения, при этом малозначимые факторы были отсеяны. Это в свою очередь уменьшило объём дальнейших исследований. Так же рассматривали зависимость факторов как линейную, после чего был сделан вывод, что линейная зависимость неадекватно описывает данные, ввиду того, что на графике функции множество точек выпадает из 95\% доверительного интервала. Факторы, влияющие на равномерность распределения картофеля по дну борозды после посадки, были выбраны следующие: $P$ - усилие прижатия катка к дну борозды, $D$ - диаметр катка, $\lambda$ - кинематический режим

После обработки результатов многофакторного эксперимента пришли к адекватной математической модели второго порядка, которая в закодированном виде описывала зависимость $R=f(P, D, \lambda)$ в следующем виде:

$$
\begin{gathered}
y=88,38+0,10300 x_{1}+0,82500 x_{2}-0,92400 x_{3}-2,42833 x_{1}^{2}-2,25833 x_{2}^{2}-1,3733 x_{3}^{2}+ \\
+\operatorname{m0} 0,87000 x_{1} x_{2}+0,75500 x_{1} x_{3}-0,78250 x_{2} x_{3}
\end{gathered}
$$

Дифференцируя уравнение (1) по переменным $x_{1}, x_{2}, x_{2}$ получаем систему состоящую из трёх дифференциальных уравнений (2):

$$
\left\{\begin{array}{c}
\frac{d y}{d x_{1}}=0,103+0,87 \cdot x_{2}+0,755 \cdot x_{3}-4,85666 \cdot x_{1}=0 \\
\frac{d y}{d x_{2}}=0,825+0,87 \cdot x_{1}-0,7825 \cdot x_{3}-2,74666 \cdot x_{2}=0 \\
\frac{d y}{d x_{3}}=-0,924+0,755 \cdot x_{1}-0,7825 \cdot x_{2}-2,74666 \cdot x_{3}=0
\end{array}\right.
$$

Решая данную систему уравнений, находим значения факторов, которые обеспечивают оптимальное значение равномерности распределения клубней картофеля по дну борозды после посадки. Они продемонстрированы в таблице 1.

Таблица 1 - Оптимальные значения факторов распределения клубней картофеля по дну борозды после посадки

\begin{tabular}{|l|c|c|}
\hline \multicolumn{2}{|c|}{ Факторы } & \multicolumn{2}{|c|}{ Оптимальные значения в виде } \\
\cline { 2 - 3 } & закодированном & раскодированном \\
\hline $\begin{array}{l}\text { P - усиление прижатия катка к дну } \\
\text { борозды, Н } \\
D-\text { диаметр катка, мм }\end{array}$ & 0,029 & 17,699 \\
\hline$\lambda$ - показатель кинематического режима & 0,439 & 136,007 \\
\hline
\end{tabular}

Для построения двумерного сечения поверхности отклика, которое характеризует величину усилия прижатия катка к дну борозды $\left(x_{1}\right)$ и показатель кинематического режима $\left(x_{3}\right)$, в уравнение (1) подставляем значение $x_{2}=0$. Получаем следующее уравнение (3):

$$
y=88,38+0,10300 x_{1}-0,92400 x_{3}-2,42833 x_{1}^{2}-1,3733 x_{3}^{2}+0,75500 x_{1} x_{3}
$$


Дифференцируя уравнение (3) по переменным $x_{1}$ и $x_{3}$ получаем систему, состоящую из двух дифференциальных уравнений:

$$
\left\{\begin{array}{l}
\frac{d y}{d x_{1}}=0,10300-4,8566 x_{1}+0,75500 x_{3}=0 \\
\frac{d y}{d x_{3}}=-0,92400+0,75500 x_{1}-2,7466 x_{3}=0
\end{array}\right.
$$

Решая уравнения системы (4), получаем в закодированном виде следующие координаты центра поверхности отклика:

$$
x_{1}=-0,032478, x_{3}=-0,345344
$$

Используя их для уравнения (3), получаем зависимость распределения клубней картофеля по дну борозды после посадки от Р - усилия прижатия к дну борозды и $\lambda$ - показателя кинематического режима (рисунок 3) в виде двумерного сечения поверхности отклика.

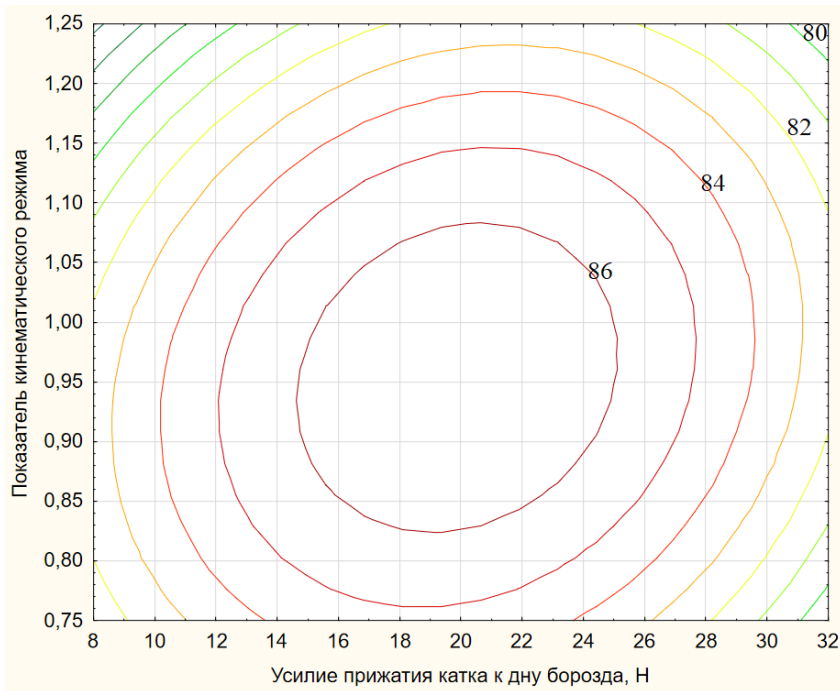

Рисунок 3 - Зависимость равномерности распределения клубней по дну борозды после посадки от усилия прижатия катка к дну борозды (Р) и показателя кинематического режима $(\lambda)$ в виде двумерного сечения поверхности отклика

Далее, по аналогии с предыдущими действиями, подставляем фактор $x_{3}$ с нулевым значением в выражение (3). Получаем следующее уравнение (5):

$$
y=88,38+0,10300 \cdot x_{1}+0,82500 \cdot x_{2}-2,42833 \cdot x_{1}^{2}-2,25833 \cdot x_{2}^{2}+0,87000 x_{1} x_{2}
$$

Дифференцируем уравнение по переменным $x_{1}$ и $x_{2}$. В итоге получаем систему из двух дифференциальных уравнений:

$$
\left\{\begin{array}{l}
\frac{d y}{d x_{1}}=0,103-4,85666 x_{1}+0,87 x_{2}=0 \\
\frac{d y}{d x_{2}}=0,825+0,87 x_{1}-4,51666 x_{2}=0
\end{array}\right.
$$

При решении системы уравнений (6), получили координаты центра поверхности отклика в закодированном виде:

$$
x_{1}=-0,011129, x_{2}=-0,180514
$$

Подставляя полученные значения в уравнение (3), строим двумерное сечение поверхности отклика, характеризующее зависимость распределения клубней картофеля по дну борозды после посадки от Р - усилия прижатия к дну борозды и $D$ - диаметра катка (рисунок 4).

Действуя по аналогии, подставляем в уравнение (3) приравненный к нулю фактор $x_{1}$ и получаем:

$$
y=88,38+0,82500 \cdot x_{2}-0,92400 \cdot x_{3}-2,25833 \cdot x_{2}^{2}-1,3733 \cdot x_{3}^{2}-0,78250 x_{2} x_{3}
$$




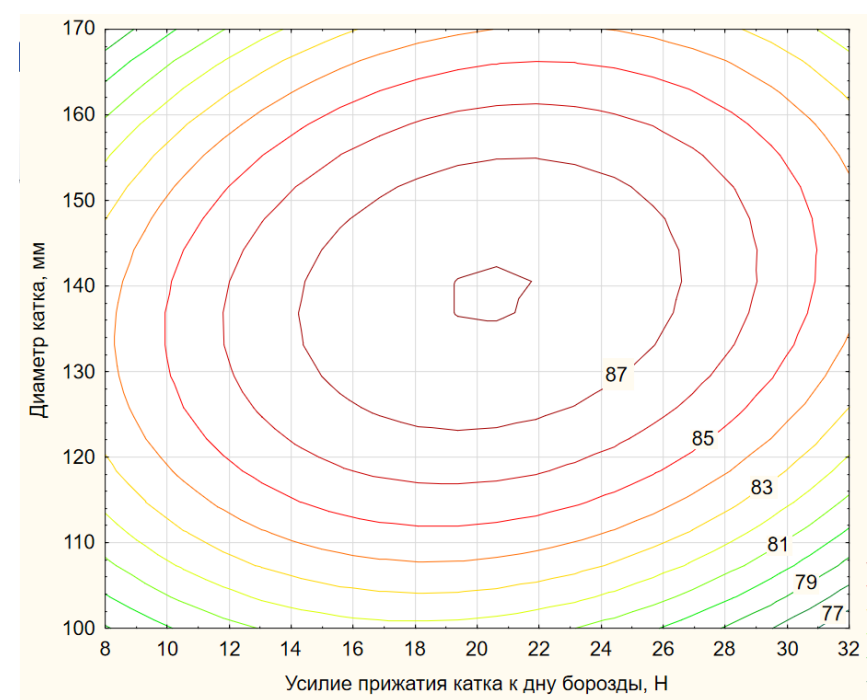

Рисунок 4 - Двумерное сечение поверхности отклика, характеризующее зависимость равномерности распределения клубней по дну борозды после посадки от усилия прижатия катка к дну борозды (P) и диаметра катка (D)

Дифференцируя уравнение (7) по переменным $x_{2}$ и $x_{3}$ получаем систему уравнений (8):

$$
\left\{\begin{array}{l}
\frac{d y}{d x_{2}}=-4,51666 x_{2}-0,78250 x_{3}-0,825=0 \\
\frac{d y}{d x_{3}}=-0,78250 x_{2}-2,7446 x_{3}-0,924=0
\end{array}\right.
$$

При решении системы уравнений (8), получаем в закодированном виде следующие координаты центра поверхности отклика:

$$
x_{2}=-0,130792, x_{3}=-0,299372 .
$$

Подставляя значения координат центра в уравнение (3), строим двумерное сечение поверхности отклика, характеризующее зависимость распределения клубней картофеля по дну борозды после посадки от Р - усилия прижатия к дну борозды и $\lambda$ - кинематического режима (рисунок 5).

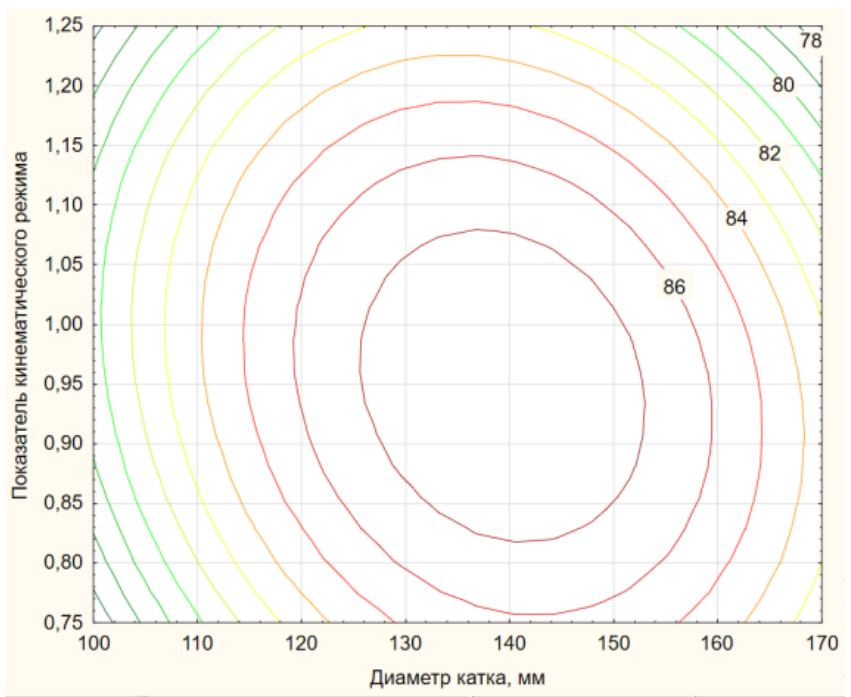

Рисунок 5 - Двухмерное сечение поверхности отклика, характеризующее зависимость равномерности распределения клубней по дну борозды после посадки от показателя кинематического режима $(\lambda)$ и диаметра катка (D) 
Анализ графических изображений двумерных сечений (рисунки 3 - 5) привел к выводу, что при параметре оптимизации (у), отвечающем за равномерность распределения картофеля по дну борозды, превышающем 86 \% оптимальные значения факторов находятся в интервалах: $14-26 \mathrm{H}$, $\mathrm{D}=115-155 \mathrm{мм}, \lambda=0,8-1,1$

Очевидно, что при инженерных расчетах уравнение (1) удобнее представлять в раскодированном виде. С учетом коэффициентов регрессии оно будет выглядеть следующим образом:

$$
\begin{gathered}
y=-25,7435+0,1343 P+1,0955 D+77,6242 \lambda+0,0035 P D+0,3775 P \lambda-0,1565 D \lambda- \\
-0,0243 P^{2}-0,0036 D^{2}-34,3334 \lambda^{2}
\end{gathered}
$$

Заключение. В результате лабораторных исследований высаживающего аппарата с ограничителем раскатывания клубней получили следующие оптимальные значения факторов, влияющих на распределение клубней картофеля при посадке: $P=14-26 \mathrm{H}$ (усилие прижатия катка к дну борозды), D = 115 - 155 мм (диаметр катка), $\lambda=0,8-1,1$ (показатель кинематического режима); при этом параметр оптимизации равномерность распределения клубней по дну борозды после посадки соответственно будет составлять не менее $86 \%$.

При использовании экспериментального высаживающего аппарата с ограничителем скорости клубней с данными конструктивными параметрами повысится урожайность производимой культуры и снизятся затраты на её производство.

\section{Список литературы}

1. ГОСТ Р 52778-2007. «Испытания сельскохозяйственной техники. Методы эксплуатационнотехнологической оценки».

2. Доспехов Б.А. Методика полевого опыта (с основами статистической обработки результатов исследований). - 5-е изд., доп. и перераб. - Москва: Агропромиздат, 1985. - 351 с

3. Халафян A.A. STATISTIC A 6: статистический анализ данных: учебник. - Москва: ООО «Бином-Пресс», 2007. - 512 с.

4. ГОСТ Р 28306-2018 «Техника сельскохозяйственная. Машины для посадки картофеля. Методы испытаний»

5. Веденяпин Г.В. Общая методика экспериментального исследования и обработки опытных данных. - М.: Колос, 1973. - 199 с.

6. Львовский Е.Н. Статические методы построения эмпирических формул. - М.: Высш. шк., 1988. -239 c.

7. Коновалов В.В. Практикум по обработке научных исследований с помощью ПЭВМ. Пенза: РИО ПГСХА, 2003 г. - 177 с.

\section{References}

1. GOST R 52778-2007. «Ispytanija sel'skohozjajstvennoj tehniki. Metody jekspluatacionnotehnologicheskoj ocenki».

2. Dospehov B.A. Metodika polevogo opyta (s osnovami statisticheskoj obrabotki rezul'tatov issledovanij). - 5-e izd., dop. i pererab. - Moskva: Agropromizdat, 1985. - $351 \mathrm{~s}$

3. Halafjan A.A. STATISTIC A 6: statisticheskij analiz dannyh: uchebnik. - Moskva: OOO «BinomPress», 2007. - 512 s.

4. GOST R 28306-2018 «Tehnika sel'skohozjajstvennaja. Mashiny dlja posadki kartofelja. Metody ispytanij»

5. Vedenjapin G.V. Obshhaja metodika jeksperimental'nogo issledovanija i obrabotki opytnyh dannyh. - M.: Kolos, 1973. - 199 s.

6. L'vovskij E.N. Staticheskie metody postroenija jempiricheskih formul. - M.: Vyssh. shk., 1988. - 239 s.

7. Konovalov V.V. Praktikum po obrabotke nauchnyh issledovanij s pomoshh'ju PJeVM. - Penza.: RIO PGSHA, 2003 g. - $177 \mathrm{~s}$.

\section{Сведения об авторах \\ Принадлежность к организации}

Бочкарев Антон Сергеевич - аспирант Федерального государственного бюджетного образовательного учреждения высшего образования «Пензенский государственный аграрный университет», Россия, г. Пенза, e-mail: bochkarev.a.s@pgau.ru.

Ларюшин Николай Петрович - доктор технических наук, профессор Федерального государственного бюджетного образовательного учреждения высшего образования «Пензенский государственный аграрный университет», Россия, г. Пенза, e-mail: larushinnp@mail.ru.

Кухарев Олег Николаевич - доктор технических наук, профессор Федерального государственного бюджетного образовательного учреждения высшего образования «Пензенский государственный аграрный университет», Россия, г. Пенза, e-mail: kucharev.o.n@pgau.ru. 


\title{
Author credentials
}

Affiliations

Bochkarev Anton - post-graduate student of Federal State Budgetary Educational Institution of Higher Education "Penza State Agrarian University”, Russia, Penza, e-mail: bochkarev.a.s@pgau.ru.

Laryushin Nikolay - Full Doctor of Technical Sciences, Professor of Federal State Budgetary Educational Institution of Higher Education "Penza State Agrarian University", Russia, Penza, e-mail: larushinnp@mail.ru.

Kuharev Oleg - Full Doctor of Technical Sciences, Professor of Federal State Budgetary Educational Institution of Higher Education "Penza State Agrarian University", Russia, Penza, e-mail: kucharev.o.n@pgau.ru.

Поступила в редакцию (Received): 11.05.2020 Принята к публикации (Accepted): 14.07.2020

УДК 631.311

DOI: $10.35887 / 2305-2538-2020-4-33-40$

\section{ПОВЫШЕНИЕ ЭФФЕКТИВНОСТИ ОБРАБОТКИ ПОЧВЫ ДЛЯ КОМБАЙНОВОЙ УБОРКИ КАРТОФЕЛЯ}

\author{
${ }^{1}$ Гаджиев Парвиз Имранович \\ ${ }^{1}$ Рамазанова Гюльбике Гудретдиновна \\ ${ }^{2}$ Манаенков Константин Алексеевич \\ ${ }^{1}$ ФГБОУ ВО «Российский государственный аграрный заочный университет» \\ ${ }^{2}$ ФГБОУ ВО «Мичуринский государственный аграрный университет»
}

Реферат. Рассматривали проблему уменьшения содержания комков в почве, с иелью подготовки ее к комбайновой уборке картофеля. Предложена почвообрабатывающая фреза с зубиеобразной формой ножа. Приведены результаты исследования влияния длины ножа фрезы, скорости вращения фрезерного барабана и числа ножей на величину крошения почвы. Предложена программа исследований с уровнями и интервалами варьирования факторов. Проведен анализ полученного уравнения регрессии, отражающего зависимость степени крошения почвы в закодированном виде от значимых факторов. Теоретические предпосылки были проверены полевыми исследованиями предлагаемой фрезы с зубиеобразным профилем ножа на полях ООО «Белая Дача Фарминг» Тамбовского района, Тамбовской области. Для испытаний выбрали поля после уборки ячменя, с помощью разработанной фрезы проводили рыхление почвы. Были получены следуюшие характеристики почвы: влажность 17 - $21 \%$, твердость - 0,8 - 1,8 МПа, плотность 0,9 - 1,0 г/см ${ }^{3}$, средняя высота растительных и пожснивных остатков - 20 см. Результать агротехнической оченки показали, что обработка почвы на глубину 11,6 см обеспечивает удовлетворительное качество крошения, плотность обрабатываемого слоя в 1,10 г/см³. Все это отвечает агротехническим требованиям созревания картофеля. Подрезаются полностью сорные растения. Высота гребней составила 1,54 - 1,62 см. В тяжельх почвах комбайны работают легче, состав вороха стал чист от комков и уменьшилось повреждение клубней. При комбайновой уборке картофеля, его урожайность на подготовленном участке, путем фрезерования выросла на $25 \%$, количество почвенных примесей в бункере снижается на $35-40 \%$.

Ключевые слова: обработка почвы, крошение, скорость вращчения фрезерного барабана, ножи с зубиеобразным профилем.

\section{IMPROVING THE EFFICIENCY OF TILLING THE SOIL} FOR COMBINE HARVESTING POTATOES

\author{
${ }^{1}$ Gadzhiyev Parviz \\ ${ }^{1}$ Ramazanova Gulbike \\ ${ }^{2}$ Manayenkov Konstantin \\ ${ }^{1}$ FSBEI HE "Russian State Agrarian Correspondence University" \\ ${ }^{2}$ FSBEI HE "Michurinsk State Agrarian University”"
}


Abstract. The problem of reducing the content of lumps in the soil, in order to prepare it for harvesting potatoes, was considered. A tillage cutter with a serrated knife shape is proposed. The results of the study of the influence of the cutter knife length, the rotation speed of the milling drum and the number of knives on the amount of crumbling of the soil are presented. A research program with levels and intervals of variation of factors is proposed. An analysis of the obtained regression equation, which reflects the dependence of the degree of crumbling of the soil in encoded form on significant factors, was carried out. Theoretical background was verified by field studies of the proposed cutters with a serrated profile of a knife in the fields of Belaya Dacha Farming LLC, Tambov District, Tambov Region. Fields after harvesting barley were selected for testing; using the developed cutter, the soil was loosened. The following soil characteristics were obtained: moisture content $17-21 \%$, hardness - 0,8 - 1,8 MPa, density - 0,9 - $1,0 \mathrm{~g} / \mathrm{cm}^{3}$, average height of plant and crop residues $-20 \mathrm{~cm}$. The results of the agrotechnical assessment showed that tillage to a depth of 11,6 cm provides a satisfactory quality of crumbling, the density of the treated layer is $1,10 \mathrm{~g} / \mathrm{cm}^{3}$. All this meets the agrotechnical requirements of potato ripening. Fully weed plants are pruned. The height of the ridges was 1,54-1,62 cm. Combines work easier in heavy soils, the composition of the heap has become clean from lumps and damage to tubers has decreased. When harvesting potatoes, their productivity in the prepared area by milling increased by $25 \%$, the amount of soil impurities in the hopper decreases by $35-40 \%$.

Keywords: tillage, crumbling, milling drum rotation speed, knives with serrated profile.

Введение. Правильный выбор технологии возделывания картофеля, в зависимости от почвенных, климатических условий приводит к улучшению качества клубней картофеля и повышению его урожайности.

С помощью комбайнов нельзя убирать картофель на задерненных и сильно засоренных участках. К комбайновой обработке пригодны только хорошо сепарируемые почвы, не содержащие твердых примесей, которые могут вызвать перегрузку основного сепаратора при повышенных скоростях комбайна.

Для снижения количества комков в почве картофельного поля предлагается использовать соответствующую обработку: боронование, фрезерование, междурядные обработки и т.п. [1 - 3].

Некоторые зарубежные фирмы пошли по другому пути $[4,5]:$ они предварительно перед посадкой освобождают почву от комков и камней, получая рыхлую и готовую к посадке почву, не требующую весеннюю вспашку и обычную подготовку ложа для клубней. Это позволяет, не расходуя значительных средств на создание специального картофелеуборочного комбайна, оборудованного дорогостоящими камнеотделителями, достигнуть высоких показателей при возделывании картофеля.

Фирма «Гримме» (Германия) предложила очищать почвенный слой от комков и камней на глубину залегания картофельных клубней при рыхлении почвы ниже уровня клубней (подпахотный горизонт) без вынимания почвы на поверхность.

Подготовка почвы с помощью почвообрабатывающих фрез перед посадкой очень перспективна при возделывании картофеля на комковатых почвах. Для снижения тяговых сопротивлений, уменьшения затрат мощности при фрезеровании, повышения скорости резания и производительности [6 - 8] необходимо правильно выбрать форму и рабочую поверхность ножа.

Потребление картофеля в 2017 году составило 112,8 кг (рекомендованная норма 90 кг). Оно остается практически неизменным на протяжении последних лет. Благодаря тому, что внутренний спрос на картофель можно считать насыщенным, для отечественных производителей открывается возможность наращивать производство картофеля отечественных элитных сортов. Предпосевная фрезерная обработка почвы становится очень актуальной. Нами предложена зубцеобразная форма ножа у почвообрабатывающей фрезы.

Активное крошение тяжелых и средних по твердости почв, в том числе с измельчением растительных остатков, уничтожением сорных растений, перемешиванием слоев почвы и выравниванием поверхности почвы можно осуществлять с помощью почвообрабатывающей фрезы ФН - 1,2, которая агрегатируется с тракторами МТ3-80 [8, 9].

Фрезерная машина или барабан представляет собой вал и приваренные к нему фланцы фрезы, имеющие зубцеобразную форму ножа, приводимого в движение от карданной передачи ВОМ трактора. При движении агрегата происходит интенсивное рыхление почвенного пласта с 
помощью подрезания ножом. Поверхность обрабатываемого слоя выравнивают фартукавыравниватели, а каток выравнивает и уплотняет разрыхленный слой почвы.

Цель исследований - провести анализ зависимости между степенью крошения почвы и факторами, влияющими на эту степень, используя метод планирования полнофакторного эксперимента.

Материалы и методы исследования. Исследовались параметры влияния усовершенствованной машины с зубцеобразной формой ножа на степень крошения почвы по методу полнофакторного планирования эксперимента. В качестве варьируемых факторов приняты следующие: длина ножа $l$, скорость вращения фрезерного барабана $\omega$ и число ножей $m$.

На интервал варьирования числа ножей влияли конструктивные особенности фрезы и глубина обработки почвы. Техническая характеристика трактора и условия работы фрезыопределяли число eе оборотов $\omega$. Длину ножа определялипо агротехническим требованиям. В таблице 1 представлены уровни и интервалы варьирования факторов на степень крошения почвы при ее обработке под картофель.

Таблица 1 - Уровни и интервалы варьирования факторов на степень крошения почвы

\begin{tabular}{|l|c|c|c|c|}
\hline \multirow{2}{*}{ Уровень } & \multirow{2}{*}{ Значение } & \multicolumn{3}{|c|}{ Факторы } \\
\cline { 3 - 5 } & & $\mathrm{m},\left(\mathrm{X}_{3}\right)$ & $l,\left(\mathrm{X}_{1}\right), \mathrm{cm}$ & $\omega,\left(\mathrm{X}_{2}\right), \mathrm{paд} / \mathrm{c}$ \\
\hline Верхний & +1 & 4 & 23,0 & 55 \\
\hline Нижний & -1 & 2 & 22,0 & 35 \\
\hline Центральный & 0 & 3 & 22,5 & 45 \\
\hline Интервал варьирования. & $\Delta \mathrm{X}$ & 1 & 0,5 & 10 \\
\hline
\end{tabular}

Для перехода фактических уровней к кодированным использовали формулы:

$$
\mathrm{X}_{1}=\frac{l-l_{0}}{\Delta l} ; \mathrm{X}_{2}=\frac{\omega-\omega_{0}}{\Delta \omega} ; \mathrm{X}_{3}=\frac{m-m_{0}}{\Delta m} .
$$

Коэффициенты регрессии определяли с помощью метода наименьших квадратов. Гипотезу об однородности оценок дисперсий проверяли с использованием критерий Фишера.

Результаты исследований и обсуждение. По рассчитанным коэффициентам получили математическую модель, характеризующую зависимость величины крошения почвы от наиболее значимых факторов:

$$
K=91,8+0,32 x_{1}+0,59 x_{2}-0,573 x_{1} x_{3}-0,76 x_{2} x_{3}-0,32 x_{1}^{2}-0,52 x_{3}^{2} \text {, }
$$

где $\mathrm{x}_{1}$ - длина ножа фрезы; $\mathrm{x}_{2}-$ угловая скорость $\omega$ вращения барабана; $\mathrm{x}_{3}-$ число $m$ ножей на диске барабана.

Для приведения к каноническому виду уравнения (1) нашли его частные производные по $\mathrm{x}_{1}$, $\mathrm{x}_{2}, \mathrm{x}_{3}$ и получили систему линейных уравнений:

$$
\left\{\begin{array}{c}
\frac{\partial K}{\partial X_{1}}=0,32-0,64 X_{1}-0,573 X_{3}=0 \\
\frac{\partial K}{\partial X_{2}}=0,59-0,76 X_{3}=0 \\
\frac{\partial K}{\partial X_{3}}=-0,573 X_{1}-0,76 X_{2}-1,04 X_{3}=0
\end{array},\right.
$$

решение которого дает координаты оптимальной точки:

$$
\mathrm{x}_{1}=-0,198 ; \mathrm{x}_{2}=-0,919 ; \mathrm{x}_{3}=0,78 \text {. }
$$

Критерий оптимизации в этой точке составляет $\mathrm{K}_{\mathrm{s}}=91,5 \%$.

Метод многофакторного планирования эксперимента позволил найти в достаточно простом и компактном виде математическую модель процесса и определить значения факторов, обеспечивающих рациональные значения.

Натуральные значения факторов, отвечающие оптимальной степени крошения почвы $i_{\text {onm }}=91,5$, имеют значения: длина ножа фрезы $l=22,4$ см; угловая скорость вращения барабана $\omega=35,8 \mathrm{c}^{-1}$; число ножей на диске барабана $m=4$.

Эти показатели имеют почти полную сходимость с теоретическими исследованиями.

Анализируя уравнение регрессии (1) получили увеличение крошения почвы по экспоненциальной зависимости с увеличением угловой скорости $\omega$ (рисунок 1). 


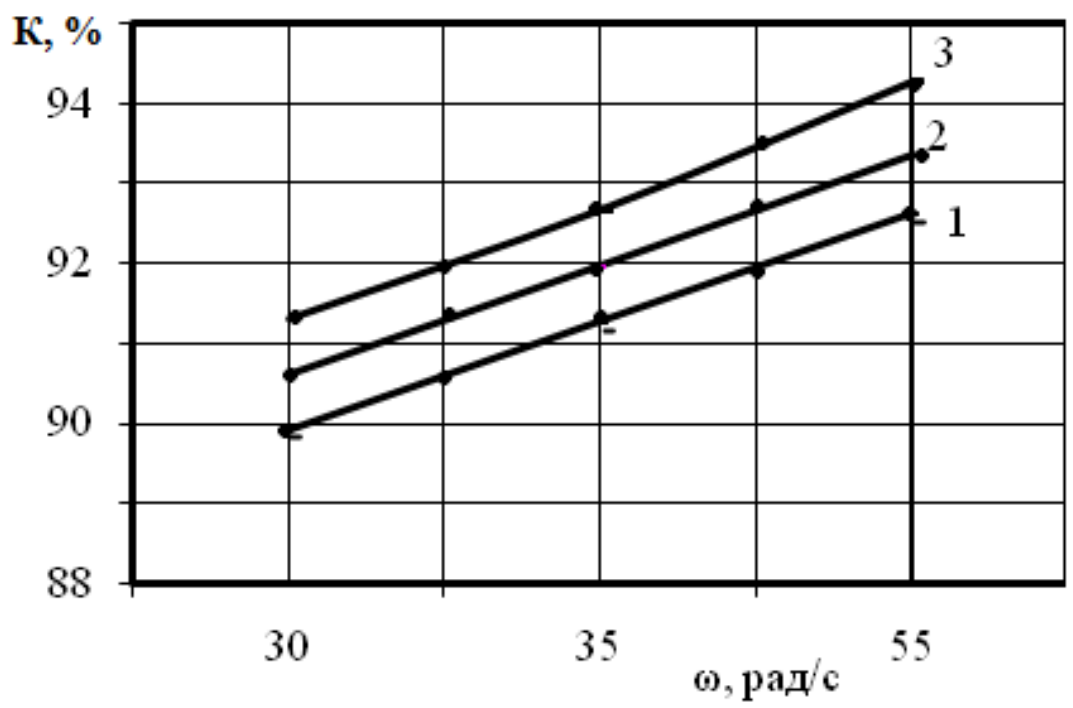

Рисунок 1 - Влияние скорости $\omega$ вращения барабана фрезы на крошение почвы при: $1-m=2$ шт.; $2-m=3$ шт.; $3-m=4$ шт.

Установили увеличение крошения почвы на $1 \%$ с увеличением угловой скорости $\omega$ вращения барабана фрезы в диапазоне $35-45$ рад/с, и на $2 \%$ (рисунок1), а в диапазоне 45 - 55 рад/с при длине ножа $l=22,5 \mathrm{~cm}$.

Если угловая скорость вращения барабана фрезы $\omega=35$ рад/с, то при увеличении количества ножей на диске барабана на 1 штуку крошение почвы увеличивается на 1,5 \%, а при увеличении количества ножей на 2 шт. - на 2 \% (рисунок 2).

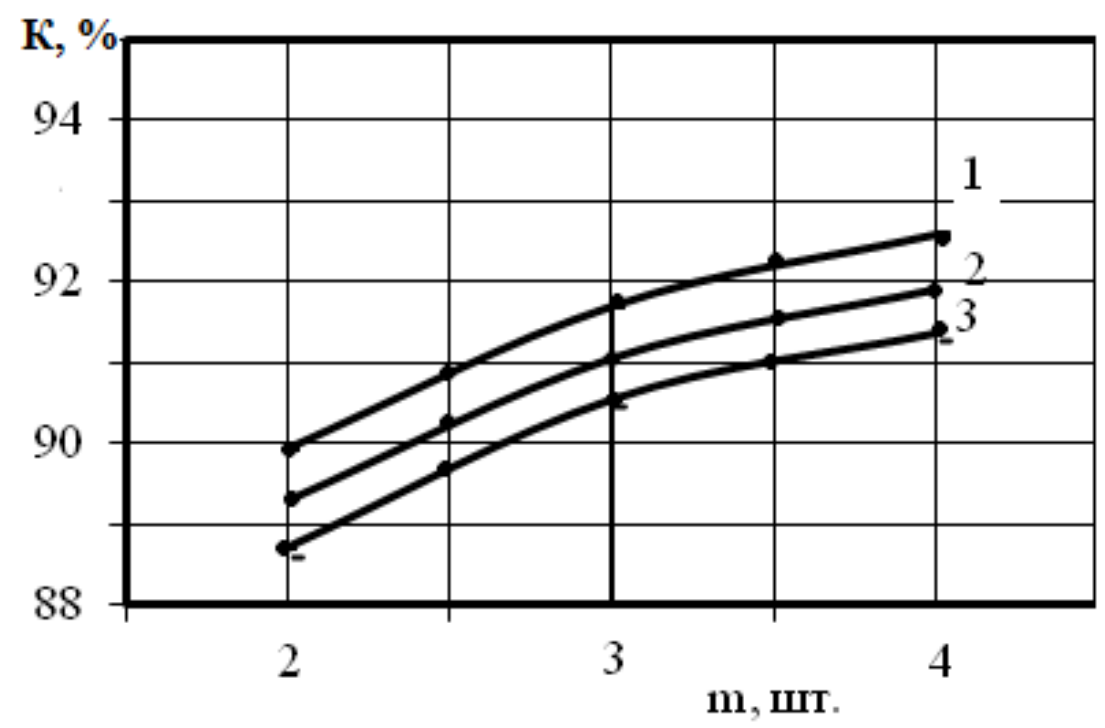

Рисунок 2 - Влияние числа ножей барабана на крошение почвы при:

$$
1-\omega_{\min }=35 \text { рад/c; } 2-\omega_{0}=45 \text { рад } / \mathrm{c} ; 3-\omega_{\max }=55 \text { рад } / \mathrm{c} \text {. }
$$

При количестве ножей $m=4$ и с увеличением длины ножа $l$ обработки почвенного пласта в диапазоне 22 - 22,5 см крошение почвы увеличивается на 1,0 \%, при 22,5 - 23 см - уменьшается на $1,5 \%$ (рисунок 3 ). 


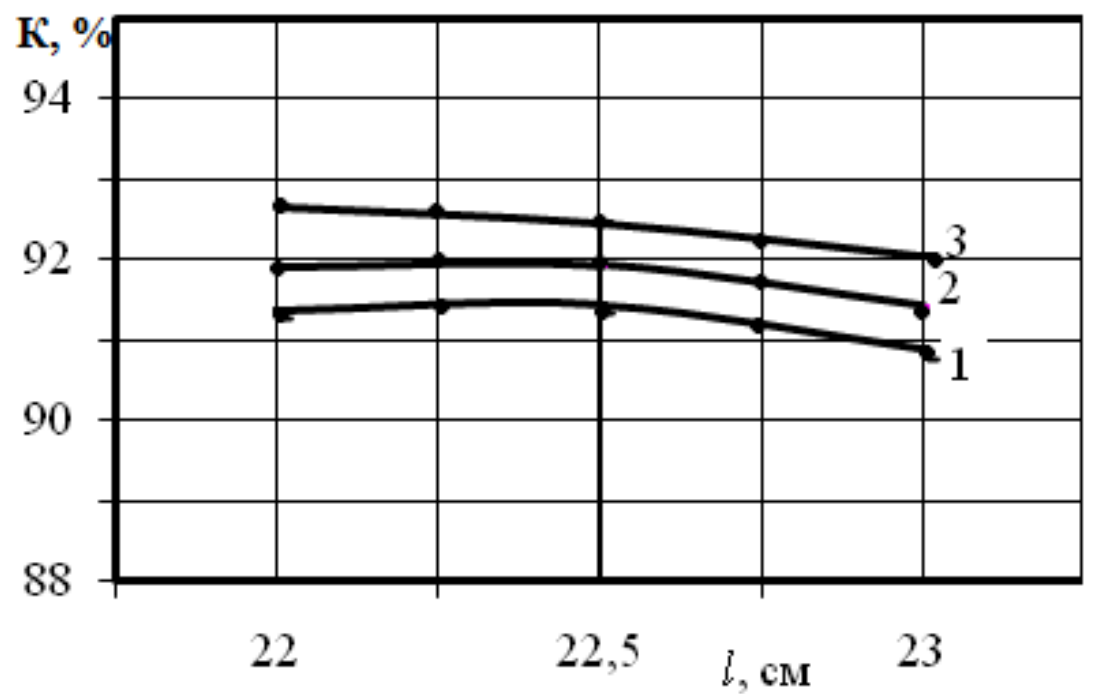

Рисунок 3 - Влияние длины ножа $l$ обработки почвенного пласта на крошение почвы при:

$$
1-\omega_{\min }=35 \text { рад/c; } 2-\omega_{0}=45 \text { рад/c; } 3-\omega_{\max }=55 \text { рад/c. }
$$

Оценка гипотезы адекватности модели (1) при использовании критерия Фишера $\mathrm{F}_{\mathrm{t}}=2,17$ говорит о ее пригодности с доверительной вероятностью $95 \%$ для прогнозирования крошения почвы после стадии фрезерования.

С целью выявления эффективности предпосадочной обработки почвы экспериментальной машиной проводились полевые испытания на землях ООО «Белая Дача Фарминг» Тамбовского района, Тамбовской области. Этот район по характеру почвенного покрова и агроклиматическим особенностям относится к центральной зоне, площадь типичных черноземов составляет здесь 19,8 \%, а площадь выщелоченных-65,9 \% [10].

Полученные при лабораторно-полевых испытаниях результаты приведены в таблице 2.

Таблица 2. -Агротехнические показатели при лабораторно - полевых испытаниях

\begin{tabular}{|c|c|c|c|}
\hline \multirow{3}{*}{$\begin{array}{l}\mathrm{N}, \\
\mathrm{n} / \mathrm{n}\end{array}$} & \multirow[t]{2}{*}{ Показатели } & \multicolumn{2}{|c|}{ Значение показателя } \\
\hline & & T3 & данные испытаний \\
\hline & Место проведения & - & $\begin{array}{c}\text { с. Татаново Тамбовский } \\
\text { район, } \\
\text { Тамбовской области, } \\
(08.10 .2017 \text { г.) }\end{array}$ \\
\hline 1 & Используемая техника & M T3 - 80 & МТ3 - $80+$ ФН 1,2 M \\
\hline 2 & Скорость движения, км/ч & $3-5$ & $3-9$ \\
\hline 3 & $\begin{array}{l}\text { Рабочая ширина захвата агрегатом, м } \\
\text { при стандартном отклонении, } \pm \text { см }\end{array}$ & $\begin{array}{c}1-2 \\
-\end{array}$ & $\begin{array}{l}1-2 \\
0,03\end{array}$ \\
\hline 4 & Характеристики почвы: & & \\
\hline & Гребнистость поверхности, см & $\leq 2$ & $1,54-1,62$ \\
\hline & Глубина обработки, см & 18,0 & 11,6 \\
\hline & $\begin{array}{l}\text { Крошение, \% } \\
\text { размеры фракций: } \\
\text { до } 25 \text { мм, \% в слое до } 60 \text { мм } \\
\text { до } 50 \text { мм, \% в слое до } 150 \text { мм } \\
\text { в слое свыше } 150 \text { мм } \\
\end{array}$ & $\begin{array}{c}50-70 \\
\geq 90\end{array}$ & $\begin{array}{l}86,5 \\
67,4 \\
97,5 \\
\end{array}$ \\
\hline & 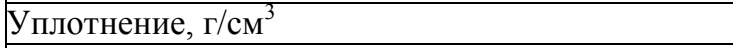 & $0,9-1,2$ & $1,0-1,1$ \\
\hline & Подрезание сорняков, \% & - & 100 \\
\hline & Заделка растительных и пожнивных остатков, \% & - & 97,3 \\
\hline
\end{tabular}


Испытания почвообрабатывающей фрезы с ножами зубцеобразной формы проводили при рыхлении почвы после уборки ячменя влажностью 17,3 - 20,9 \%, твердостью - 0,8 - 1,8 МПа,

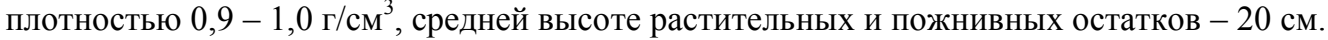

Агротехническую оценку почвы проводили, используя СТО АИСТ 1.1 - 2004, ГОСТ 20315-75. Полученные результаты показали удовлетворительное качество крошения почвы при обработке на глубину 11,6 см. Плотность обрабатываемого слоя составила 1,10 г/см³, высота гребней - 1,54 1,62 см. Сорные растения, при этом, подрезаются полностью. Все это соответствует агротехническим требованиям для созревания картофеля.

Чтобы проверить эффективность предпосадочной подготовки почвы под картофель, путем фрезерования комковатых почв осенью был проведен анализ учета урожайности картофеля и ход комбайновой уборки картофеля.

Для полевых испытаний использовали те земельные участки, где почва была подготовлена перед посадкой клубней. Условия проведения полевых испытаний картофелеуборочного комбайна приведены в таблице 3, уборка картофеля проводилась двухрядным картофелеуборочным комбайном Dewulf (рисунок 3).

Таблица 3 - Условия проведения предпосадочной обработки почвы с помощью картофелеуборочного комбайна Dewulf

\begin{tabular}{|c|c|c|}
\hline Агротехнические показатели & \multicolumn{2}{|c|}{ Значение } \\
\hline & $\begin{array}{l}\text { Без предварительной } \\
\text { обработки почвы }\end{array}$ & $\begin{array}{c}\text { Предпосадочная обработка } \\
\text { почвы }\end{array}$ \\
\hline Климатические факторы: & \\
\hline $\begin{array}{l}\text { Многолетние данные по средней } \\
\text { температуре в мае-сентябре, }{ }^{0} \mathrm{C},\end{array}$ & \multicolumn{2}{|c|}{$15,3 / 14,9$} \\
\hline $\begin{array}{l}\text { Многолетние данные по сумме осадков в } \\
\text { мае-сентябре, мм }\end{array}$ & \multicolumn{2}{|c|}{$318 / 18$} \\
\hline $\begin{array}{l}\text { Название по механическому составу почв: } \\
\text { Рельеф почв }\end{array}$ & \multicolumn{2}{|c|}{$\begin{array}{l}\text { средний суглинок, } \\
\text { ровный, выровненный }\end{array}$} \\
\hline \multicolumn{3}{|l|}{$\begin{array}{l}\text { Влажность,\% / твердость, Мпа почвы в } \\
\text { слоях: }\end{array}$} \\
\hline $20-25$ & $23,1 / 0,91$ & $21,4 / 0,88$ \\
\hline $15-20$ & $22,1 / 0,98$ & $21,8 / 0,60$ \\
\hline $10-15$ & $20,8 / 0,62$ & $21,0 / 0,46$ \\
\hline $5-10$ & $20,7 / 0,49$ & $20,6 / 0,23$ \\
\hline $0-5 \mathrm{~cm}$ & $23,0 / 0,32$ & $20,9 / 0,20$ \\
\hline Сорт картофеля & \multicolumn{2}{|c|}{ «Инноватор» } \\
\hline Схема посадки, см & \multicolumn{2}{|c|}{$70 \times 30$} \\
\hline Высота гребня, см & 16,7 & 11,3 \\
\hline Ширина междурядий, см & 71,2 & 70,3 \\
\hline Размеры клубней & & \\
\hline длина средняя, мм & 47,0 & 49,0 \\
\hline среднее квадратическое отклонение, \pm см & 15,4 & 12,2 \\
\hline ширина средняя, см & 36,0 & 40,0 \\
\hline среднее квадратическое отклонение, +- см & 12,6 & 10,7 \\
\hline толщина средняя, мм & 28,0 & 28,0 \\
\hline среднее квадратическое отклонение, \pm см & 9,3 & 8,3 \\
\hline Средняя масса клубня, г & 72,0 & 88,0 \\
\hline Коэффициент формы клубней & 1,23 & 1,18 \\
\hline Урожайность клубней, т/га & 18,0 & 22,5 \\
\hline \multicolumn{3}{|l|}{ Состав клубней в процентах по массе, г } \\
\hline свыше 80 & 55,3 & 64,2 \\
\hline $50-80$ & 28,3 & 26,9 \\
\hline $15-50$ & 16,4 & 8,9 \\
\hline Полнота выкапывания клубней, \% & 96,8 & 99,7 \\
\hline
\end{tabular}




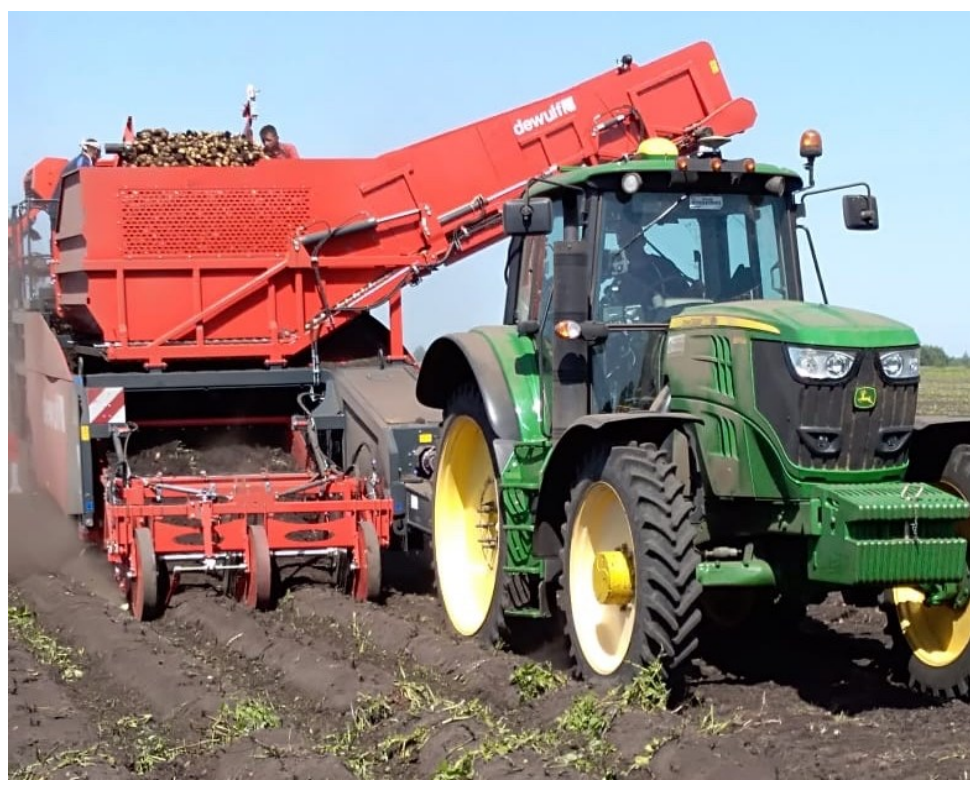

Рисунок 3 - Двухрядный картофелеуборочный комбайн Dewulf в работе

В тяжелых почвах комбайны стали работать легче, состав вороха стало чисто от комков и уменьшилась повреждения клубней.

Как видно из показателей условий проведения испытаний при комбайновой уборке картофеля, его урожайность на подготовленном участке, путем фрезерования выросла почти на $25 \%$, количество почвенных примесей в бункере снижается на $35-40 \%$.

На подготовленной почве под посадку картофеля производительность комбайнов увеличивается на 13 - 15 \%, повреждения клубней при комбайновой уборке снижается на $20 \%$, в последствие расход топлива на уборку сократилась на $11 \%$.

\section{Выводы:}

1. Рассмотрена задача полнофакторного планирования эксперимента для исследования степени крошения почвы при предпосадочной обработке под картофель.

2. Получена математическая модель процесса крошения в виде уравнения регрессии второго порядка и определены значения факторов, обеспечивающих рациональные значения крошения.

3. Проведены полевые исследования усовершенствованного образца фрезы с зубцеобразной формой ножа для предпосадочной подготовки почвы. В результате урожайность картофеля выросла на 25 \%, повреждения клубней в таре при комбайновой уборке сократилось на 20 \%.

\section{Список литературы}

1. Гаджиев П.И. Новый комплекс машин для возделывания картофеля // Механизация и электрификация сельского хозяйства. - 1998. - № 12.

2. Петров Г.Д. Развитие механизации возделывания картофеля // Плодоовощное хозяйство. 1986. - № 9.

3. Петров Г.Д. Картофелеуборочные машины. М.: Машиностроение. - 1984. - 320 с.

4. Новые технологические и технические решения в механизации и уборке картофеля (зарубежный опыт). Киев. - 1984. - 26 с.

5. Вирзбург Ф., Найбауэр В. Технология выращивания и уборки картофеля в ГДР // Международный сельскохозяйственный журнал. - 1976. - № 3.

6. Bernacki H. Bodonia zuzycia energii przez aktywne i combinawane maszyny uprowowe // Biuletyn prac naukowobadawczych. - Warszawa, 1975. - №10 - S. 35 - 48.

7. Sohne W., Eggenmuller A. Schnellaufende bodenfrasen langsamlanfende rotorgraber // Grundlagen der landtechnik. H. II. 1959.

8. Рамазанова Г.Г. Параметры и режимы работы фрезы для предпосадочной обработки почвы под картофель: дис. ... канд. техн. наук.: М., -2016. - 133 с. 
9. Гаджиев П.И. Технология и технические средства для подготовки тяжелых и каменистых почв к посадке и комбайновой уборке картофеля / П.И. Гаджиев, // Монография. - 2002.- 160 с.

10. Агротехнические показатели фрезерования почвы с зубцеобразной формой ножа / П.И. Гаджиев, М.С. Шикалов, Г.Г. Рамазанова, А.И Алексеев // Материалы Международной заочной научно-практической конференции «Ресурсосберегающие экологически безопасные технологии и оборудованиев АПК» РГАЗУ, 18-19 апреля 2019 г.

\section{References}

1. Gadzhiev P.I. Novyj kompleks mashin dlja vozdelyvanija kartofelja // Mehanizacija i jelektrifikacija sel'skogo hozjajstva. - 1998. - № 12.

2. Petrov G.D. Razvitie mehanizacii vozdelyvanija kartofelja // Plodoovoshhnoe hozjajstvo. - 1986. - № 9.

3. Petrov G.D. Kartofeleuborochnye mashiny. M.: Mashinostroenie. - 1984. - 320 s.

4. Novye tehnologicheskie i tehnicheskie reshenija v mehanizacii i uborke kartofelja (zarubezhnyj opyt). Kiev. - 1984. -26 s.

5. Virzburg F., Najbaujer V. Tehnologija vyrashhivanija i uborki kartofelja V GDR // Mezhdunarodnyj sel'skohozjajstvennyj zhurnal. - 1976. - № 3.

6. Bernacki H. Bodonia zuzycia energii przez aktywne i combinawane maszyny uprowowe // Biuletyn prac naukowobadawczych. - Warszawa, 1975. - №10 - S. 35 - 48.

7. Sohne W., Eggenmuller A. Schnellaufende bodenfrasen langsamlanfende rotorgraber // Grundlagen der landtechnik. H. II. 1959.

8. Ramazanova G.G. Parametry i rezhimy raboty frezy dlja predposadochnoj obrabotki pochvy pod kartofel': dis. ... kand. tehn. nauk.: M., - 2016. - 133 s.

9. Gadzhiev P.I. Tehnologija i tehnicheskie sredstva dlja podgotovki tjazhelyh i kamenistyh pochv $\mathrm{k}$ posadke i kombajnovoj uborke kartofelja / P.I. Gadzhiev, // Monografija. - 2002.- 160 s.

10. Agrotehnicheskie pokazateli frezerovanija pochvy s zubceobraznoj formoj nozha / P.I. Gadzhiev, M.S. Shikalov, G.G. Ramazanova, A.I Alekseev // Materialy Mezhdunarodnoj zaochnoj nauchnoprakticheskoj konferencii «Resursosberegajushhie jekologicheski bezopasnye tehnologii i oborudovaniev APK» RGAZU, 18-19 aprelja 2019 g.

\section{Сведения об авторах \\ Принадлежность к организации}

Гаджиев Парвиз Имранович - доктор технических наук, профессор Федерального государственного бюджетного образовательного учреждения высшего образования «Российский государственный аграрный заочный университет», Россия, г. Балашиха, e-mail: pgadjiev@yandex.ru.

Рамазанова Гюльбике Гудретдиновна - кандидат технических наук, доцент Федерального государственного бюджетного образовательного учреждения высшего образования «Российский государственный аграрный заочный университет», Россия, г. Балашиха, e-mail: gulbike@yandex.ru.

Манаенков Константин Алексеевич - доктор технических наук, профессор Федерального государственного бюджетного образовательного учреждения высшего образования «Мичуринский государственный аграрный университет», Россия, г. Мичуринск, e-mail: kmanaenkov@yandex.ru.

\section{Author credentials}

\section{Affiliations}

Gadgiev Parviz - Full Doctor of Technical Sciences, Professor of Federal State Budgetary Educational Institution of Higher Education "Russian State Agrarian Correspondence University", Russia, Balashikha, e-mail: pgadjiev@yandex.ru.

Ramazanova Gulbike - Candidate of Technical Sciences, Associate Professor of Federal State Budgetary Educational Institution of Higher Education "Russian State Agrarian Correspondence University”, Russia, Balashikha, e-mail: gulbike@yandex.ru.

Manayenkov Konstantin - Full Doctor of Technical Sciences, Professor of Federal State Budgetary Educational Institution of Higher Education "Michurinsk State Agrarian University", Russia, Michurinsk, e-mail: kmanaenkov@yandex.ru.

Поступила в редакцию (Received): 29.05.2020 Принята к публикации (Accepted): 14.07.2020 
УДК 631.332 .7

DOI: $10.35887 / 2305-2538-2020-4-41-46$

\title{
ОСОБЕННОСТИ РАБОТЫ КАРТОФЕЛЕСАЖАЛОК
}

\author{
${ }^{1}$ Башкирев Анатолий Петрович \\ ${ }^{1}$ Шварц Анатолий Адольфович \\ ${ }^{1}$ Иванов Никита Андреевич \\ ${ }^{l}$ ФГБОУ ВО «Курская государственная сельскохозяйственная академия имени И.И. Иванова»
}

Реферат. Использование картофелесажалок существенно снижает трудозатрать на посадку картофеля. Проведен сравнительный анализ использующихся в настоящее время картофелесажалок, ux конструктивных особенностей и технических характеристик. Исследования проводились в Курской области. Определено, что наиболее распространень картофелесажалки полунавесного типа, которые предназначены для посадки пророщенных и не пророщенных клубней картофеля весом от 30 до 100 г. Обозначена необходимость учета таких параметров картофелесажалок, как глубина внесения минеральных удобрений и их количество, рабочая скорость, ширина захвата сажалки, глубина и частота посадки клубней картофеля. Отмечено, что для длительной работы без перерывов для загрузки посадочного материала и удобрений необходима большая емкость бункеров. Требуется регулировка параметров, соединение сажалки с трактором и загрузка клубней картофеля и удобрений перед работой, но во время посадки конструкция картофелесажалок не требует специального обслуживания или дополнительных настроек. В результате анализа моделей картофелесажсалок, сформировано табличное представление их технических параметров. Приведены данные об ориентировочной стоимости картофелесажалок серий КСМ, Л-200 и СК-4. Сравнение представленных данных позволяет определить особенности применения моделей для конкретных условий проведения посадочных работ. От правильного выбора технических характеристик картофелесажалки, зависит качество посадки и, соответственно, результаты итогового урожая.

Ключевые слова: картофелесажалка, сравнительный анализ, табличное представление, технические характеристики, минеральные удобрения, посадочный материал.

\section{FEATURES OF POTATO PLANTER WORK}

\author{
${ }^{1}$ Bashkirev Anatoly \\ ${ }^{1}$ Schwartz Anatoly \\ ${ }^{1}$ Ivanov Nikita
}

\section{${ }^{I}$ FSBEI HE "Kursk State Agricultural Academy”}

Abstract. The use of potato planters significantly reduces labor costs for planting potatoes. A comparative analysis of currently used potato planters, their design features and technical characteristics is carried out. The research was carried out in the Kursk region. It has been determined that the most widespread are semi-mounted potato planters, which are designed for planting sprouted and nonsprouted potato tubers weighing from 30 to $100 \mathrm{~g}$. The need to take into account such parameters of potato planters as the depth of application of mineral fertilizers and their amount, working speed, width of the planter, depth and frequency of planting potato tubers is indicated. It is noted that for long-term work without interruptions, a large capacity of bunkers is required for loading planting material and fertilizers. It is necessary to adjust the parameters, connect the planter to the tractor and load potato tubers and fertilizers before work, but during planting, the design of the potato planters does not require special maintenance or additional settings. The tabular presentation of their technical parameters was formed as a result of the analysis of models of potato planters. Data on the approximate cost of potato planters of the KSM, L-200 and SK-4 series are given. Comparison of the presented data makes it possible to determine the features of using the models for specific conditions of planting operations. The quality of planting and, accordingly, the results of the final harvest depend on the correct choice of technical characteristics of the potato planter.

Keywords: potato planter, comparative analysis, tabular presentation, technical characteristics, mineral fertilizers, planting material. 
Введение. Использование картофелесажалок позволяет механизировать один из самых трудоемких процессов в сельском хозяйстве. Их применение существенно снижает трудозатраты на посадку картофеля. Поэтому они получили широкое распространение, как в малых, так и в больших хозяйствах $[1,2]$.

Существует несколько видов картофелесажалок, которые отличаются методом подачи посадочного материала. К одному из видов относят модели, в которых клубни перемещаются пальцевым типом подачи, то есть картофель попадает к пальцевым металлическим захватам, которыми подается в место посадки [3 - 5]. Имеются сажалки, в которых применяют плоскоременный метод подачи клубней, благодаря горизонтально расположенным ремням, или имеющие систему фасонных ремней, позволяющую сохранять проросший картофель, благодаря выемкам на ремнях. Различают мультиременной метод посадки сразу двух рядов, ложечковый тип подачи, когда посевной материал перемещается конструкцией с захватами типа ложек, закрепленных к ремню, а также метод посадки, когда картофель подается накалывающим способом $[6,7]$.

Основой картофелесажалки является рама, на которую крепятся все механизмы. В ее передней части находится шланг гидросистемы, разъем для подключения электрооборудования и балка прицепа.

Спереди расположены колеса, затем два тукоразбрасывающих бункера, диски для закрывания клубней почвой, задние колеса, загрузочные бункеры.

Во время движения картофелесажалки, из главного бункера, клубни перемещаются в питательный ковш встряхивателями и ворошителями. Затем шнековый механизм по одному клубню отправляет картофель на щиток-отражатель, откуда он попадает в борозду, сформированную сошником.

В зависимости от установленных перед посадкой дисков или борон, для формирования верхней части грядки, получают поверхность, соответственно, гребневой или гладкой формы.

Наиболее распространены картофелесажалки полунавесного типа. Они предназначены для посадки пророщенных и не пророщенных клубней картофеля. Вес клубня для таких сажалок может составлять от 30 до 100 г. Они обладают высокой производительностью и могут использоваться на больших площадях $[8,9]$.

Перед началом проведения работ необходимо провести настройку картофелесажалки. Расстояние между рядами регулируетсяперемещением высаживающих аппаратов по поверхности рамы на задней балке. После совмещения крепежных отверстий, производится фиксация конструкций болтами. Устанавливается норма высадки клубней картофеля и норма внесения в почву минеральных удобрений.

Регулировку некоторых параметров необходимо выполнять в полевых условиях. Выбирается уровень загрузки питательного ковша, настраивается глубина, на которую будет углубляться сошник, настраивается также угол, с которым он входит в почву, путем регулировки наклона бороздо - закрывающих дисков, устанавливается глубина посадки клубней. Так же производится настройка туковысевающих механизмов [10].

Материалы и методы. Для проведения исследований особенностей функционирования картофелесажалок, необходимо проанализировать использующиеся в настоящее время модели, их параметры и технические характеристики.

Некоторые картофелесажалки предусматривают возможность доукомплектования ее дополнительными механизмами для протравливания клубней картофеля или внесения удобрения во время посадки, если базовые параметры сажалки картофеля не включают в себя этих функций.

При выборе сажалки картофеля необходимо учитывать такие особенности моделей, как ширина междурядий, которая может быть на них установлена, рабочая ширина захвата картофелесажалки, вместимость бункера для посадочного материала, и при его наличии, вместимость бункера для минеральных удобрений.

Эти характеристики могут оказывать влияние на скорость проведения работ, производительность и качество посадки, что влияет на целесообразность использования в конкретных условиях именно рассматриваемой модели.

Результаты и их обсуждение. В результате сравнительного исследования, сформировано табличное представление основных технических параметров современных навесных и полунавесных картофелесажалок. 
КСМ-2 отличается небольшими габаритными размерами, может быть использована для двухрядной посадки на всех типах почвы. Данная картофелесажалка позволяет быстро и просто менять расстояние междурядий, перемещением высаживающих аппаратов вдоль рамы. Использование металлических звездочек, повышает надежность сажалки. Опционально доступно оборудование для протравливания и внесения удобрений. Имеет навесную модификацию КСМ-2H.

Универсальность сажалки картофеля КСМ-4 обусловлена возможностью установки междурядий в три положения. Объем бункера позволяет реже производить дополнительную загрузку высаживаемых клубней, что существенно увеличивает скорость проведения работ. Имеет надежную конструкцию, с увеличенным диаметром ведомой звездочки. На картофелесажалке установлен механизм для внесения минеральных удобрений и есть возможность дооснастить сажалку протравливателем клубней. Рабочая скорость данной модели может составлять от 4 до 10 км/ч.

СК-4 имеет бункер для посадочного материала объемом 2500 кг,с гидравлическим механизмом его подъема и опускания. Данная картофелесажалка может быть настроена на три вида междурядий. Она производит бережную подачу клубней из питающего отсека, без «двойников». СК-4 имеет 4-рядную конструкцию, что позволяет производить посадку с большой шириной захвата. В ней предусмотрены механизмы для протравливания клубней и внесения минеральных удобрений.

Модель обладает высокими показателями производительности и позволяет производить посадочные работы со скоростью от 5 до 8 км/ч.

В таблице 1 представлено сравнение технических характеристик навесных и полунавесных картофелесажалок КСМ-2, КСМ-2Н, КСМ-4 и СК-4.

Таблица 1 - Сравнение технических параметров картофелесажалок КСМ-2, КСМ-2Н, КСМ-4 и СК-4

\begin{tabular}{|l|c|c|c|c|}
\hline $\begin{array}{l}\text { Модель } \\
\text { картофелесажалки }\end{array}$ & КСМ-2 & КСМ-2Н & КСМ-4 & СК-4 \\
\hline Тип & Полунавесная & Навесная & Полунавесная & Полунавесная \\
\hline Междурядье, мм & 700,750 & 700,750 & $700,750,900$ & $700,750,900$ \\
\hline Количество рядков & 2 & 2 & 4 & 4 \\
\hline $\begin{array}{l}\text { Агрегатирование с } \\
\text { тракторами,л.с }\end{array}$ & до 75 & до 75 & $75-90$ & $80-90$ \\
\hline $\begin{array}{l}\text { Мроизводительность } \\
\text { макс., га/ч }\end{array}$ & 0,82 & 1,50 & 2,10 & 2,90 \\
\hline Объем бункера, кг & 450 & 450 & 1500 & 2500 \\
\hline Внесение удобрений & опционально & опционально & есть & есть \\
\hline Протравливание & опционально & опционально & опционально & есть \\
\hline Вид картофеля & семенной & семенной & семенной & семенной \\
\hline Рабочая скорость, км/ч & $4-10$ & $4-10$ & $4-10$ & 5-8 \\
\hline
\end{tabular}

Графическое представление ориентировочной стоимости представленных в таблице 1 картофелесажалок КСМ-2, КСМ-2Н, КСМ-4 и СК-4, показано на рисунке 1. На горизонтальной оси расположены модели сажалок картофеля, на вертикальной - приведена ориентировочная стоимость представленных агрегатов.

Четырехрядная сажалка картофеля СПК-4 подходит для посадки с междурядьями 700 и 750 мм, на площадях от 10 га. Она позволяет высаживать клубни картофеля с одновременным внесением минеральных удобрений.

Двухрядная навесная сажалка Л-201 имеет механизм защиты сошника от наезда на твердые препятствия. 


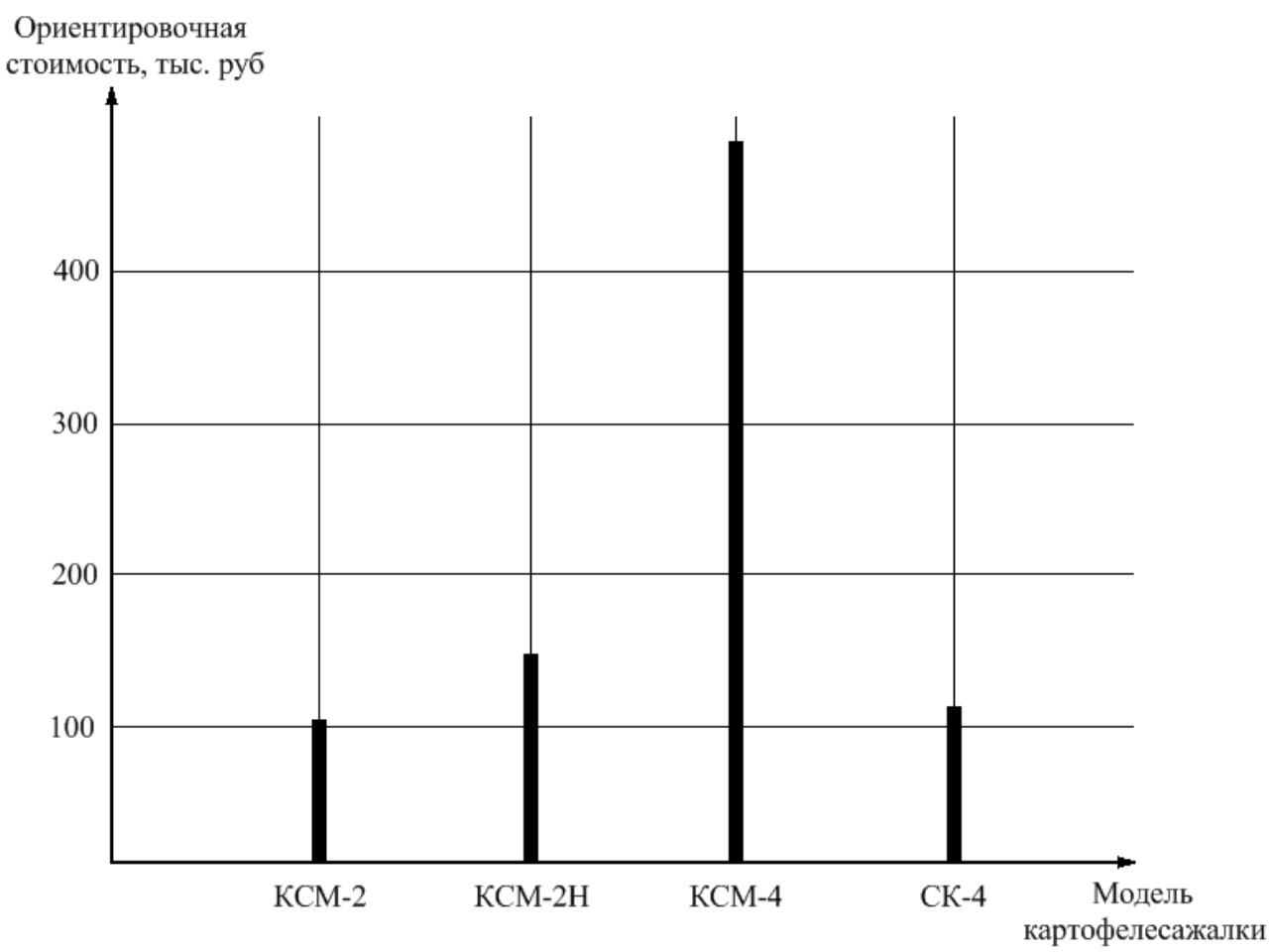

Рисунок 1 - Ориентировочная стоимость картофелесажалок

Технические параметры картофелесажалок СПК-2, Л-201, Л-202 и Л-207 приведены в таблице 2.

Таблица 2 - Технические параметры картофелесажалок СПК-2, Л-201, Л-202, Л-207

\begin{tabular}{|l|c|c|c|c|}
\hline $\begin{array}{l}\text { Модель } \\
\text { картофелесажалки }\end{array}$ & СПК-4 & Л-201 & Л-202 & Л-207 \\
\hline Тип & Навесная & Навесная & Навесная & Полунавесная \\
\hline Междурядье, мм & 700,750 & $625,700,750$ & 700 & $700,750,900$ \\
\hline Количество рядков & 4 & 2 & 4 & 4 \\
\hline $\begin{array}{l}\text { Агрегатирование с } \\
\text { тракторами,л.с }\end{array}$ & $75-90$ & от 25 & 2,40 & от 80 \\
\hline $\begin{array}{l}\text { Производительность } \\
\text { макс., га/ч }\end{array}$ & 0,23 & 1,14 & 600 & 3,24 \\
\hline Объем бункера, кг & 700 & 250 & опционально & есть \\
\hline Внесение удобрений & есть & опционально & опционально & опционально \\
\hline Протравливание & нет & опционально & непророщенный & непророщенный \\
\hline Вид картофеля & $\begin{array}{l}\text { проро- } \\
\text { щенный }\end{array}$ & непророщенный & непро & $4-10$ \\
\hline Рабочая скорость, км/ч & $0,5-1,0$ & $4-10$ & $4-10$ & \\
\hline
\end{tabular}

Картофелесажалка Л-202 позволяет просто изменять параметры густоты высадки клубней в почву. Имеет бункер для посадочного материала решетчатого типа.

Полунавесная Л-207 имеет гидравлический механизм для перемещения бункера для загрузки посадочного материала, междурядья могут быть установлены в одно из трех рабочих положений. Обладает высокими показателями производительности - до 3,24 га/ч. 
Ориентировочная стоимость представленных в таблице 2 моделей картофелесажалок показана на рисунке 2 .

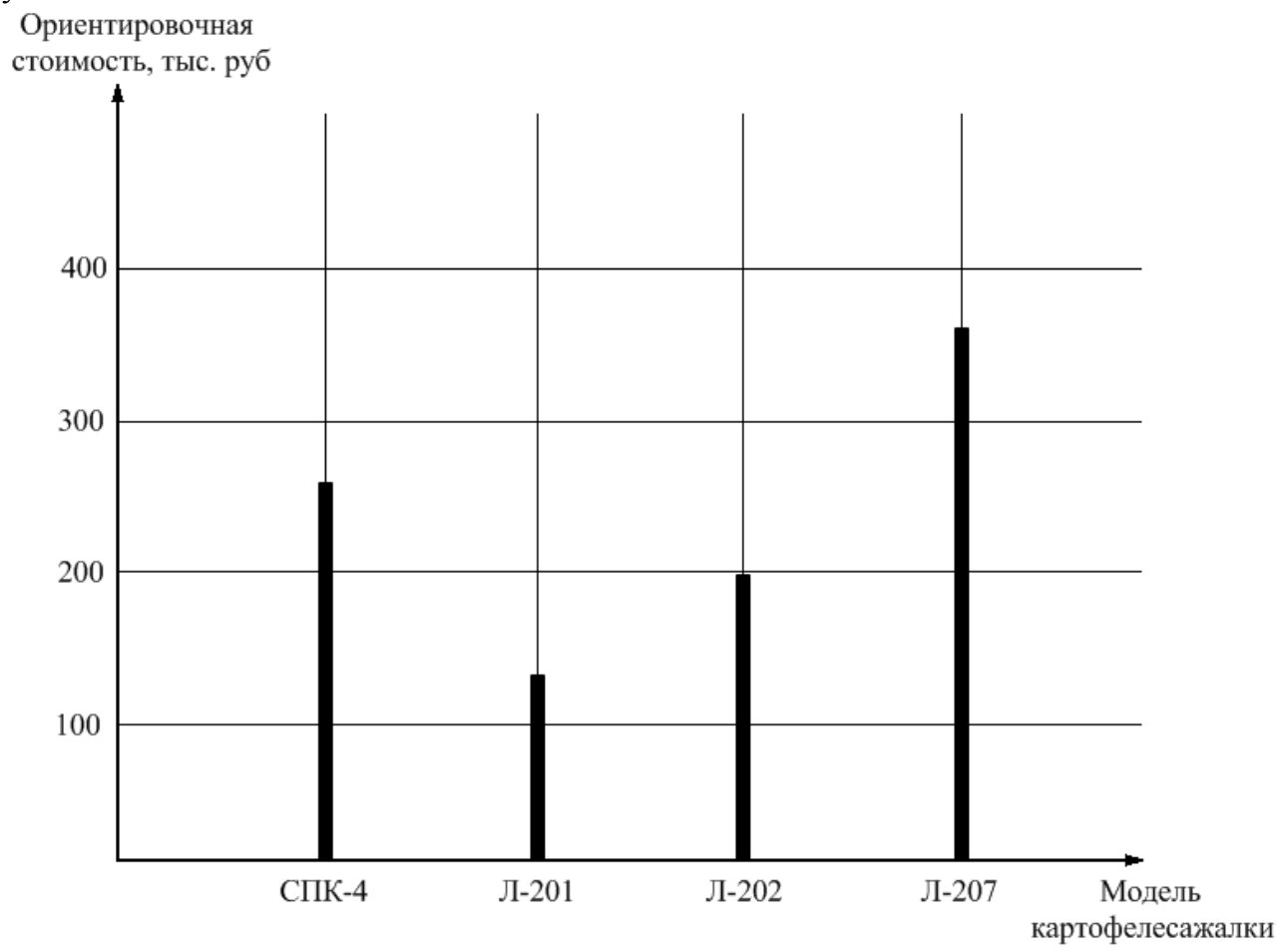

Рисунок 2 - Ориентировочная стоимость представленных моделей картофелесажалок

Заключение. В результате формирования табличного представления технических параметров картофелесажалок, был проведен анализ особенностей моделей, оказывающих влияние на их эффективность в зависимости от рабочих условий.

Правильный выбор сажалки картофеля, исходя из ее технических характеристик, обуславливает качество последующего проведения посадочных работ и итогового урожая.

\section{Список литературы}

1. Попов Ю.В., Савушкин С.Н., Бухонова Ю.В., Шебалин Е.Н. Припосадочная обработка клубней картофеля // Защита и карантин растений. - 2013. - № 5. - С. 42-44.

2. Бышов Н.В. Принципы и методы расчета и проектирования рабочих органов картофелеуборочных машин // Учебное пособие. - Рязань: Изд-во ФГБОУ ВПО РГАТУ. - 2005. № 3. - C. 282-285.

3. Кухарев О.Н., Ларюшин Н.П., Гришин Г.Е., Федянин С.Н. Результаты исследования малогабаритной картофелесажалки // Нива Поволжья. - 2012. - № 1 (22). - С. 78-83.

4. Бартенев И.И., Гаврин Д.С. Конструктивные особенности посадочных машин // Лесотехнический журнал. - 2019. - №3. - С. 47-49.

5. Картофелесажалки. Их виды и особенности / URL:http://pro-motobloki.ru/navesnoe-oborudovaniedlya-motoblokov/231-kartofelesazhalki-ih-vidy-i-osobennosti.html (дата обращения 12.05.2020).

6. Плаксин А.Г. Обзор отечественных и зарубежных картофелесажалок // Вестник Курской государственной сельскохозяйственной академии. - 2008. - № 3. - С. 33-35.

7. Никулин А.В. Усовершенствование картофелесажалки // Сельский механизатор. - 2012. №2. - C. 6-7.

8. Кухарев, О.Н., Роньжин А.А. Малогабаритная картофелекопалка для личных подсобных хозяйств // Вклад молодых ученых в инновационное развитие АПК России: сборник статей научно-практической конференции МНИЦ ПГСХА. - 2010. -№ 2. С. 152-153. 
9. Картофелесажалки. Картофелекопатели и картофелесажалки / URL: http://www.brocgaus.ru/text/048/872.html (дата обращения 12.05.2020).

10. Классификация картофелесажалок и агротехнические требования / URL:http://sejalki.ru/articles/kartofelesazhalki/klassifikatsiya-kartofelesazhalok-i.html (дата обращения 05.05.2020).

\section{References}

1. Popov YU.V., Savushkin S.N., Buhonova YU.V., SHebalin E.N. Priposadochnaya obrabotka klubnej kartofelya // Zashchita i karantin rastenij. - 2013. - № 5. - S. 42-44.

2. Byshov N.V. Principy i metody rascheta i proektirovaniya rabochih organov kartofeleuborochnyh mashin // Uchebnoe posobie. - Ryazan': Izd-vo FGBOU VPO RGATU. - 2005. - № 3. - S. 282-285.

3. Kuharev O.N., Laryushin N.P., Grishin G.E., Fedyanin S.N. Rezul'taty issledovaniya malogabaritnoj kartofelesazhalki // Niva Povolzh'ya. - 2012. - № 1 (22). - S. 78-83.

4. Bartenev I.I., Gavrin D.S. Konstruktivnye osobennosti posadochnyh mashin // Lesotekhnicheskij zhurnal. - 2019. - №3. - S. 47-49.

5. Kartofelesazhalki. Ih vidy i osobennosti / URL:http://pro-motobloki.ru/navesnoe-oborudovaniedlya-motoblokov/231-kartofelesazhalki-ih-vidy-i-osobennosti.html(data obrashcheniya 12.05.2020).

6. Plaksin A.G. Obzor otechestvennyh i zarubezhnyh kartofelesazhalok // Vestnik Kurskoj gosudarstvennoj sel'skohozyajstvennoj akademii. - 2008. - № 3. - S. 33-35.

7. Nikulin A.V. Usovershenstvovanie kartofelesazhalki // Sel'skij mekhanizator. - 2012. - №2. - S. 6-7.

8. Kuharev, O.N., Ron'zhin A.A. Malogabaritnaya kartofelekopalka dlya lichnyh podsobnyh hozyajstv // Vklad molodyh uchenyh v innovacionnoe razvitie APK Rossii: sbornik statej nauchnoprakticheskoj konferencii MNIC PGSKHA. - 2010. - № 2. S. 152-153.

9. Kartofelesazhalki. Kartofelekopateli i kartofelesazhalki / URL: http://www.brocgaus.ru/text/048/872.html (data obrashcheniya 12.05.2020).

10. Klassifikaciya kartofelesazhalok i agrotekhnicheskie trebovaniya / URL:http://sejalki.ru/articles/kartofelesazhalki/klassifikatsiya-kartofelesazhalok-i.html (data obrashcheniya 05.05.2020).

\section{Сведения об авторах}

\section{Принадлежность к организации}

Башкирев Анатолий Петрович - доктор технических наук, профессор Федерального государственно бюджетного образовательного учреждения высшего образования «Курская государственная сельскохозяйственная академия», Россия, г. Курск, e-mail: tmv46@mail.ru.

Шварц Анатолий Адольфович - доктор сельскохозяйственных наук, профессор Федерального государственно бюджетного образовательного учреждения высшего образования «Курская государственная сельскохозяйственная академия», Россия, г. Курск, e-mail: aashwarz@mail.ru.

Иванов Никита Андреевич - аспирант Федерального государственно бюджетного образовательного учреждения высшего образования «Курская государственная сельскохозяйственная академия», Россия, г. Курск, e-mail: juck0v.mih@yandex.ru.

\section{Author credentials}

\section{Affiliations}

Bashkirev Anatoly - Full Doctor of Technical Sciences, Professor of Federal State Budgetary Educational Institution of Higher Education "Kursk State Agricultural Academy”, Russia, Kursk, e-mail: tmv46@mail.ru.

Shvarts Anatoly Adolfovich - Full Doctor of Agricultural Sciences, Professor of Federal State Budgetary Educational Institution of Higher Education "Kursk State Agricultural Academy", Russia, Kursk, e-mail: aashwarz@mail.ru.

Ivanov Nikita - graduate student of Federal State Budgetary Educational Institution of Higher Education "Kursk State Agricultural Academy”, Russia, Kursk, e-mail: juck0v.mih@yandex.ru. 
УДК 631.332 .7

DOI: $10.35887 / 2305-2538-2020-4-47-53$

\title{
РЕЗУЛЬТАТЫ ИССЛЕДОВАНИЙ ЭКСПЕРИМЕНТАЛЬНОГО СОШНИКА КАРТОФЕЛЕСАЖАЛКИ
}

\author{
${ }^{1}$ Башкирев Анатолий Петрович \\ ${ }^{1}$ Швари Анатолий Адольфович \\ ${ }^{1}$ Иванов Никита Андреевич \\ ${ }^{l}$ ФГБОУ ВО «Курская государственная сельскохозяйственная академия имени И.И. Иванова»
}

Реферат. Картофель является одной из важнейших культур в сельском хозяйстве. Механизация такого трудоемкого процесса как посадка картофеля, позволяет производить работы с высокой скоростью, получать ровные ряды, создавать благоприятные условия для прорастания клубней. Картофелесажалки могут оснащаться механизмами для внесения минеральных удобрений и протравливания клубней картофеля. Некоторые модели сажалок могут поддерживать опцию дооснащения данными механизмами. Цель работь - разработка дополнительных загортачей для сошника, позволяющих увеличить высоту почвенного слоя между вносимыми удобрениями и высаживаемыми клубнями. Полунавесная картофелесажалка КСМ-4 позволяет устанавливать междурядья в одно из трех предусмотренных положений $u$ применяется для четырехрядной посадки. Из бункера данной сажалки, клубни попадают в питательный ковш, затем они поступают к высаживающему аппарату, где ложечками, по одному, через щиток-отражатель направляются в борозду к задней части сошника. Удобрения поступают в его переднюю часть через туковысевающий аппарат. Почва укрывает удобрения, благодаря конструкиии щек сошника, создавая слой в 30-40 мм под высаживаемыми клубнями. Такие условия проведения работ, могут приводить к ожоговым повреждениям посадочного материала. Разработка дополнительных загортачей для сошника и исследования на тему высаживающих аппаратов проводились в Курской области. В результате разработки и проведенных испытаний, почвенный слой, отделяющий удобрения от клубней, был увеличен до $55-65$ мм. Такая высота почвы, позволяет защитить клубни картофеля от ожоговых воздействий, вносимых при посадке удобрений, обеспечивая оптимальные условия для их прорастания.

Ключевье слова: картофель, сошник, картофелесажалка, междурядья, минеральные удобрения.

\section{THE RESULTS OF STUDIES OF EXPERIMENTAL SEED POTATO PLANTER}

\author{
${ }^{1}$ Bashkirev Anatoly \\ ${ }^{1}$ Schwartz Anatoly \\ ${ }^{1}$ Ivanov Nikita \\ ${ }^{1}$ FSBEI HE “Kursk State Agricultural Academy”
}

Abstract. Potatoes are one of the most important crops in agriculture. Mechanization of such a labor-intensive process as potato planting allows you to work at a high speed, get even rows, and create favorable conditions for sprouting tubers. Planters can be equipped with mechanisms for the application of mineral fertilizers and treatment of potato tubers. Some models of planters can support the option of retrofitting with these mechanisms. The purpose of this work is to develop additional coulter plugs that allow increasing the height of the soil layer between the applied fertilizers and the planted tubers. The KSM-4 semi-suspended potato planter allows you to set the aisles in one of the three positions provided and is used for four-row planting. From the hopper of this planters, the tubers fall into the feeding bucket, then they go to the planting device, where they are spoons, one at a time, through the shieldreflector are sent to the furrow to the back of the Coulter. Fertilizers come in the front through fertilizermachine. The soil covers the fertilizers, thanks to the design of the ploughshare cheeks, creating a layer of 30-40 mm under the planted tubers. Such working conditions can lead to burn damage to the 
planting material. The development of additional ploughshares and research on landing devices were carried out in the Kursk region. As a result of development and testing, the soil layer separating fertilizers from tubers was increased to 55-65 mm. This height of the soil allows you to protect potato tubers from the burn effects of fertilizers applied during planting, providing optimal conditions for their germination.

Keywords: potatoes, coulter, potato planters, row spacing, mineral fertilizers.

Введение. Во многих округах нашей страны, картофель имеет самый большой процент от общего числа высаживаемых культур. Его посадка является одним из наиболее трудоемких процессов в сельском хозяйстве, поэтому для механизации данного вида труда был разработан такой вид сельскохозяйственной техники, как картофелесажалки. Использование для посадки картофеля сажалок, позволяет выполнять работы с высокой скоростью, равномерно распределять клубни по площади посадочных работ, выдерживая одинаковую глубину посадки, при этом снизив трудозатраты $[1,2]$.

Картофелесажалки могут отличаться устанавливаемым на них значением междурядий, показателями производительности, объемом бункера. Основные виды междурядий - 700, 750, 900 мм.

Наиболее распространенным значением является 700 мм, оно поддерживается большинством моделей сажалок картофеля. Устанавливаемое значение расстояния между рядами в 750 мм, так же может быть настроено на многих картофелесажалках [3, 4].

От объема бункера, зависит какое количество посадочного материала можно загрузить в сажалку. Чем больше это значение, тем реже возникает необходимость прерывать рабочий процесс посадки для его дополнительной загрузки. Те же условия применимы и к бункеру для минеральных удобрений, при его наличии на данном виде техники [5].

Так же у сажалок картофеля может отличаться такой параметр технических характеристик, как рабочая скорость и скорость транспортировки.

Если скорость транспортирования картофелесажалки влияет лишь на время ее перемещения к месту проведения работ, то рабочая скорость, влияет на параметр производительности, то есть какая площадь будет засажена картофелем, за час рабочего времени [6].

Для картофелесажалки КСМ-4 угол входа сошника в рабочую поверхность должен быть таким, чтобы при положении рамы горизонтально относительно земли и касании передней части сошника почвы, задняя его часть, была выше уровня земли на 45-50 мм. Угол его входа в почву изменяют путем установки в необходимое положение верхней резьбовой тяги.

Затем необходимо произвести установку параметра глубины хода сошников в необходимое положение. Путем настройки регулировок картофелесажалки в транспортное положение, проверяют ограничители механизма опускания сошников. Изменяя положение болта на резьбе, в которой он расположен на данном ограничителе, производят регулировку [7].

Минеральные удобрения вносятся в район передней части сошника. За счет особенностей конструкции его щек, происходит осыпание рыхлой почвы накрывающей их, образуя слой высотой около 30-40 мм.

В заднюю часть сошника на поверхность засыпанных почвой удобрений подаются высаживаемые клубни, которые заделываются либо сферическими дисками, либо боронами, в зависимости от заданного типа формирования верхней части грядки $[8,9]$.

Такой уровень почвенного слоя между высаживаемыми клубнями и минеральными удобрениями, может приводить к ожоговым повреждениям картофеля, от избытка питательных веществ, из-за его близости к внесенным удобрениям [10].

В этой связи, разработка дополнительных загортачей для сошника картофелесажалки, является актуальной и представляет практический интерес. Увеличение высоты слоя почвы над минеральными удобрениями до уровня 55-65 мм, позволит защитить высаживаемые клубни от ожоговых воздействий вносимых при посадке удобрений, обеспечивая оптимальные условия для их прорастания, что в результате положительно скажется на итоговой урожайности.

Материалы и методы. Для проведения исследований экспериментального сошника картофелесажалки были разработаны дополнительные загортачи, позволяющие повысить уровень слоя почвы над удобрениями, рисунок 1. Для изготовления был использован металл толщиной 
2 мм. Уголки для их крепления выполнены из такого же материала. Использование металла с оцинкованным покрытием позволит избежать возникновения коррозии, что актуально для конструкции, подвергающейся механическим воздействиям, а так же воздействиям вносимых во время посадки удобрений.

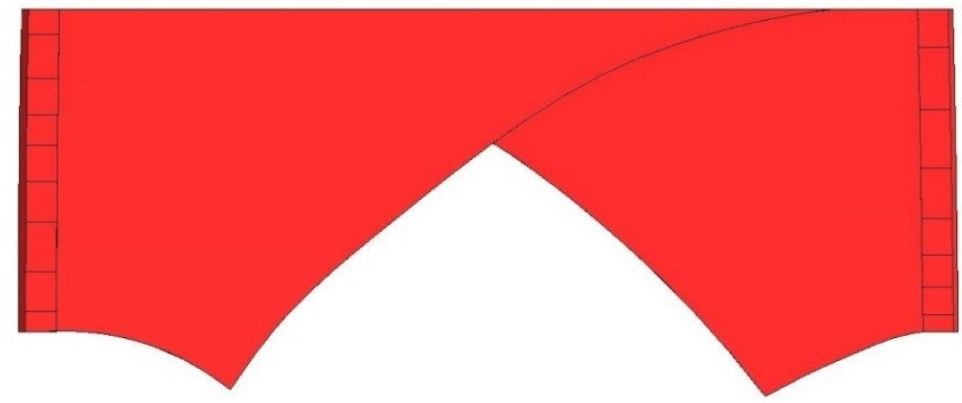

a)
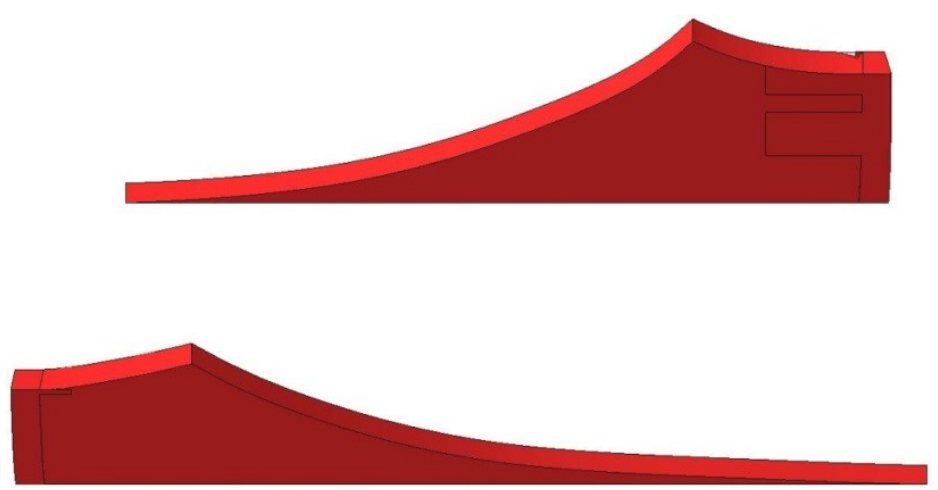

б)

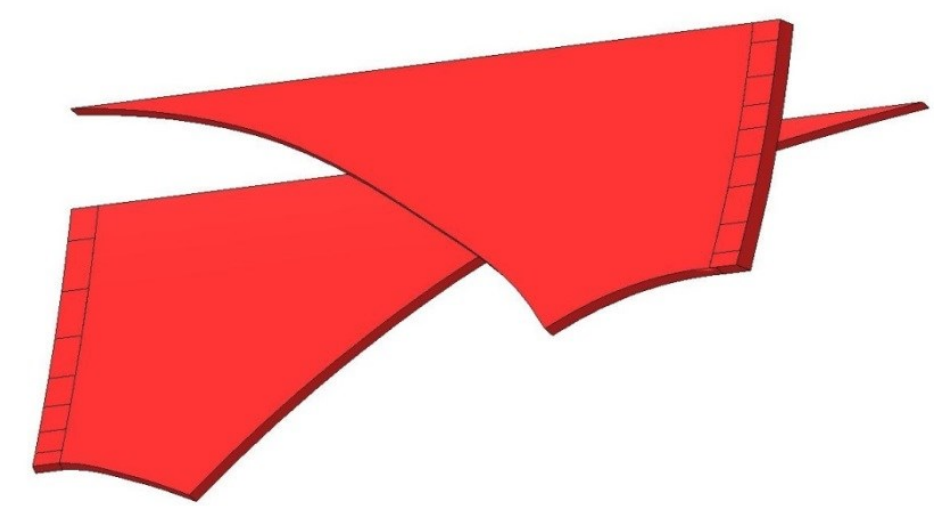

B)

а) - вид спереди; б), в) - наглядное объемное изображение формы загортачей относительно вида снизу и сзади соответственно

Рисунок 1 - Дополнительные загортачи для сошника картофелесажалки

Их крепление производится к боковым стенкам сошника и к нижней плоскости горизонтальной планки, как показано на рисунках 2 и 3, винтами с внешней стороны и гайками через гроверные шайбы - с внутренней, размером М3. К стенкам каждый загортач имеет две точки крепления, к планке - три, что в результате обеспечивает их надежное соединение с сошником. 


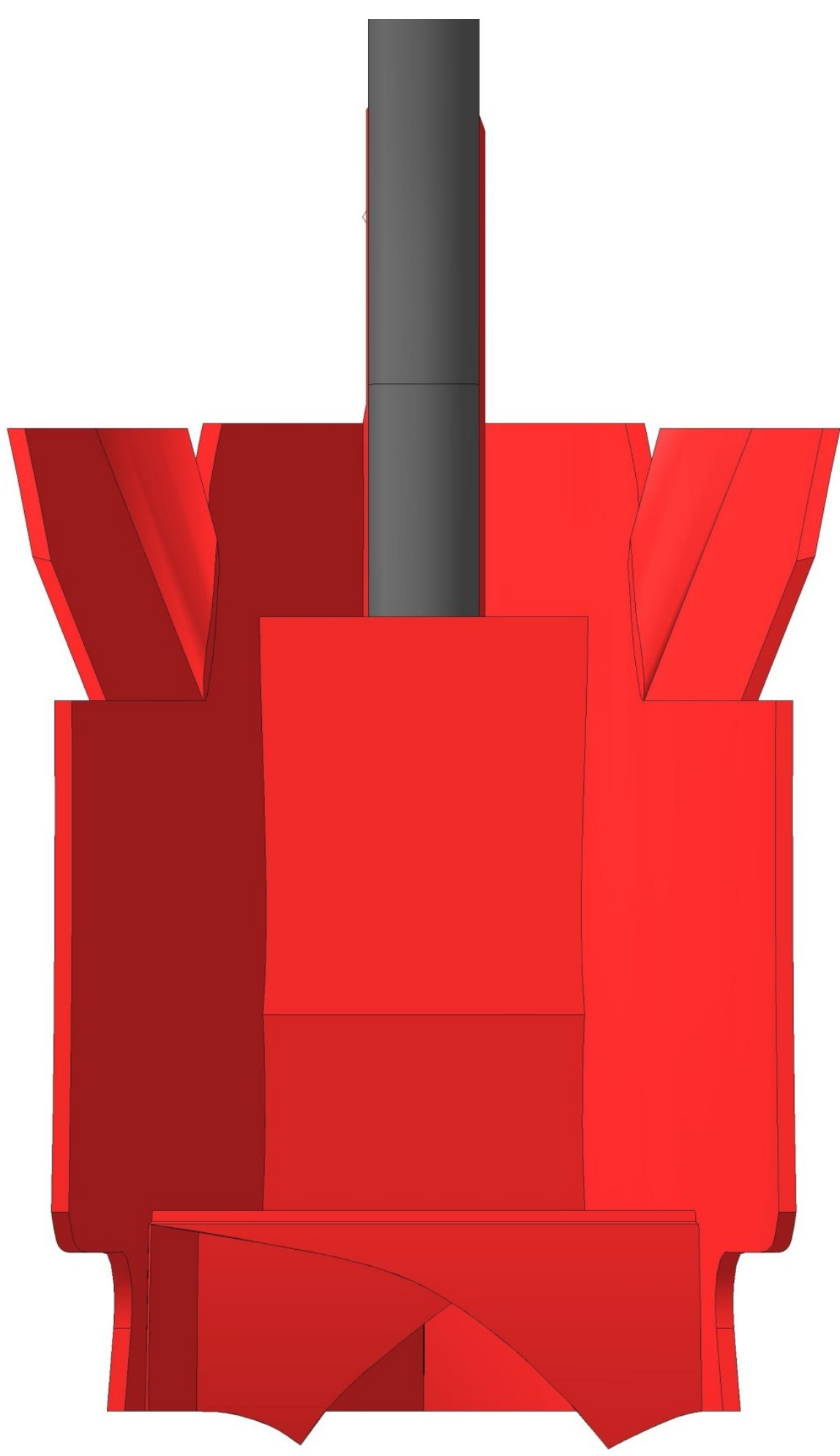

Рисунок 2 - Расположение дополнительных загортачей на сошнике картофелесажалки

Представленное на рисунке 2 изображение показывает установленные на сошник картофелесажалки дополнительные загортачи, вид сзади. 
На рисунке 3 показано объемное представление установленных загортачей на сошник, смещенное относительно аксонометрической проекции, что позволяет наглядно продемонстрировать места установки разработанных конструкций.

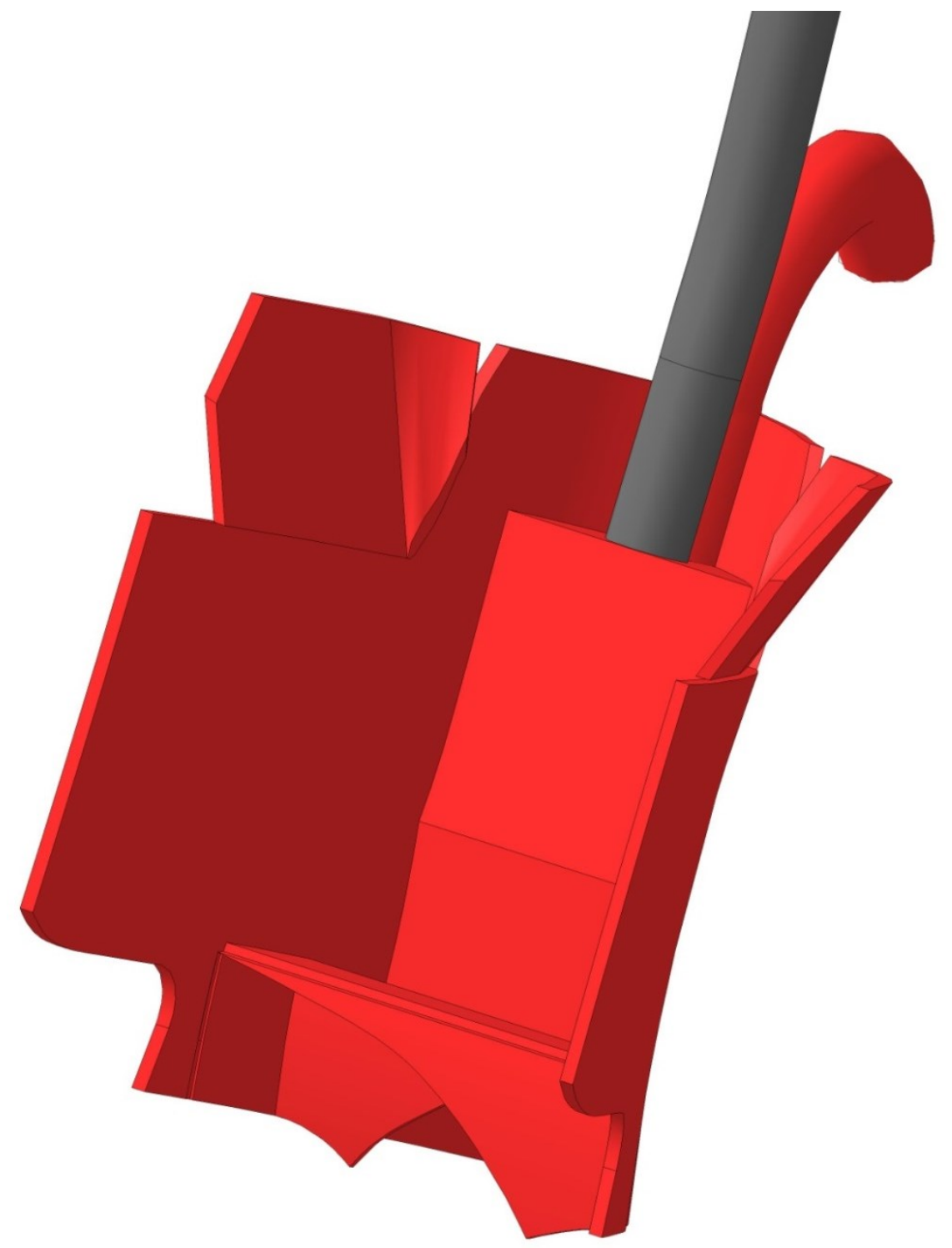

Рисунок 3 - Объемное представление установленных загортачей на сошник

При изменении регулировочных параметров сошника, можно легко снять и заменить дополнительные загортачи, на подходящие для текущих настроек данного рабочего органа. Их снятие и установка в освободившиеся отверстия элементов крепежа, позволяет восстановить конструкцию сошника, в изначальное состояние.

Результаты и их обсуждение. Форма загортачей выбрана так, чтобы во время хода сошника, их изогнутые заостренные края входили в землю, перемещая слой рыхлой почвы на вносимые минеральные удобрения. Конструкция загортачей по длине крепления к планке, в сторону противоположную от стенок, придает захватываемой почве форму, ограничивая высоту насыпи уровнем в 25 мм. 
Дополнительное укрытие удобрений позволяет добавить к слою почвы высотой 30-40 мм, обеспечивающемуся осыпанием земли за счет формы щек сошника, необходимую для уровня в 55-65 мм высоту.

Графическое представление высаженных в почву клубней картофеля показано на рисунке 4.

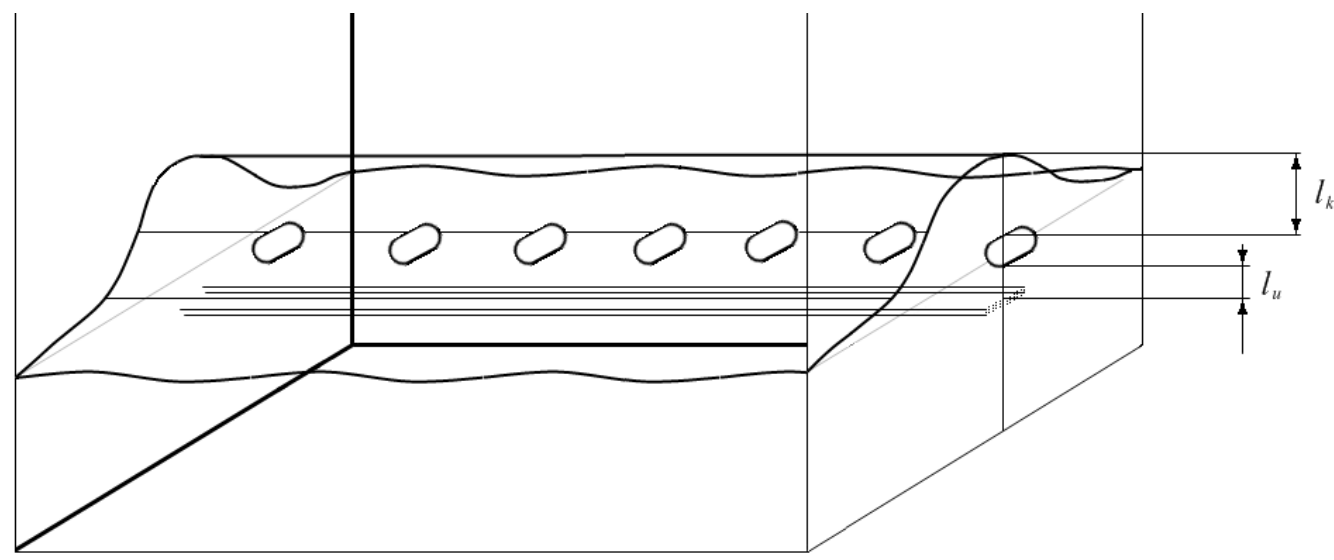

Рисунок 4 - Графическое представление высаженных в почву клубней картофеля

Значения глубины посадки и внесения удобрений в почву варьируются в пределах $l_{k}=80-$ 100 мм и $l_{u}=55-65$ мм соответственно.

Таким образом, процесс посадки картофеля, с использованием предложенных в данной статье доработок, будет осуществляться следующим образом. В ходе проведения посадочных работ, минеральные удобрения засыпаются в район передней части сошника. Рыхлая почва, за счет конструкции щек сошника, осыпается сверху удобрений, установленные на перекладине сошника загортачи, дополнительно укрывают их. В заднюю часть сошника на поверхность засыпанных почвой удобрений подаются высаживаемые клубни.

Такой уровень почвенного слоя между картофелем и минеральными удобрениями, сможет защитить клубни от избытка питательных веществ, из-за их близости к вносимым удобрениям.

В результате проведенных исследований экспериментального сошника картофелесажалки, были получены значения высоты слоя почвы между внесенными минеральными удобрениями и высаживаемыми клубнями 55 - 65 мм.

Заключение. Таким образом, предложенный в данной статье вариант модернизации сошника картофелесажалки КСМ-4, позволит обеспечивать во время проведения работ, уровень почвенного слоя между удобрениями и высаживаемыми клубнями, достаточный для защиты картофеля от ожоговых повреждений.

\section{Список литературы}

1. Репетов А.Н. О развитии механизации работ в растениеводстве // Вестник Курской государственной сельскохозяйственной академии. - 2010. - №1. - С. 79-81.

2. Плаксин А.Г. Обзор отечественных и зарубежных картофелесажалок // Вестник Курской государственной сельскохозяйственной академии. - 2008. - № 3. - С. 33-35.

3. Картофелесажалки. Их виды и особенности / URL: http://pro-motobloki.ru/navesnoe-oborudovaniedlya-motoblokov/231-kartofelesazhalki-ih-vidy-i-osobennosti.html (дата обращения 12.05.2020).

4. Чхетиани А.А. Анализ современных технологий возделывания картофеля и конструкций картофелеуборочных машин // Технические науки - от теории к практике. - 2011. - №4. - С. 21 - 26.

5. Технологии возделывания картофеля / URL: http://fermer.ru/sovet/rastenievodstvo/20431 (дата обращения 24.04.2020).

6. Бышов Н.В. Принципы и методы расчета и проектирования рабочих органов картофелеуборочных машин // Учебное пособие. - Рязань: Изд-во ФГБОУ ВПО РГАТУ. - 2005. № 3. - С. 282-285.

7. Технология выращивания картофеля / URL: http://www/agrobase.ru/rastenievodstvo/texnologiiproizvodstva/kartofelya (дата обращения 26.04.2020). 
8. Картофелесажалка КСM-4: технические характеристики, принцип работы / URL: http://yandex.ru/turbo/s/agronom.expert/posadka/ogorod/paslenovye/kartofel/obzor-kartofelesazhalki$\mathrm{ksm}-4 . \mathrm{html}$ (дата обращения 23.04.2020).

9. Механизм картофелесажалки КСМ-4. Подробно о тракторах и сельскохозяйственной технике / URL: http://tractor-server.ru/kartofelesazhalka-ksm-4-ustrojstvo-i-princip-dejstviya/ (дата обращения 8.05.2020).

10. Подготовка трактора и сажалки к работе. Технологии и машины для посадки картофеля / URL: http://studwood.ru/1689662/agropromyshlennost/podgotovka_traktora_sazhalki_rabote_ (дата обращения 16.05.2020).

\section{References}

1. Repetov A.N. O razvitii mehanizacii rabot v rastenievodstve // Vestnik Kurskoj gosudarstvennoj sel'skohozjajstvennoj akademii. - 2010. - №1. - S. 79-81.

2. Plaksin A.G. Obzor otechestvennyh i zarubezhnyh kartofelesazhalok // Vestnik Kurskoj gosudarstvennoj sel'skohozjajstvennoj akademii. - 2008. - № 3. - S. 33-35.

3. Kartofelesazhalki. Ih vidy i osobennosti / URL: http://pro-motobloki.ru/navesnoe-oborudovaniedlya-motoblokov/231-kartofelesazhalki-ih-vidy-i-osobennosti.html (data obrashhenija 12.05.2020).

4. Chhetiani A.A. Analiz sovremennyh tehnologij vozdelyvanija kartofelja $i$ konstrukcij kartofeleuborochnyh mashin // Tehnicheskie nauki - ot teorii k praktike. - 2011. - №4. - S. 21 - 26.

5. Tehnologii vozdelyvanija kartofelja / URL: http://fermer.ru/sovet/rastenievodstvo/20431 (data obrashhenija 24.04.2020).

6. Byshov N.V. Principy i metody rascheta i proektirovanija rabochih organov kartofeleuborochnyh mashin // Uchebnoe posobie. - Rjazan': Izd-vo FGBOU VPO RGATU. - 2005. - № 3. - S. $282-285$.

7. Tehnologija vyrashhivanija kartofelja / URL: http://www/agrobase.ru/rastenievodstvo/texnologiiproizvodstva/kartofelya (data obrashhenija 26.04.2020).

8. Kartofelesazhalka KSM-4: tehnicheskie harakteristiki, princip raboty / URL: http://yandex.ru/turbo/s/agronom.expert/posadka/ogorod/paslenovye/kartofel/obzor-kartofelesazhalkiksm-4.html (data obrashhenija 23.04.2020).

9. Mehanizm kartofelesazhalki KSM-4. Podrobno o traktorah i sel'skohozjajstvennoj tehnike / URL: http://tractor-server.ru/kartofelesazhalka-ksm-4-ustrojstvo-i-princip-dejstviya/ (data obrashhenija 8.05.2020).

10. Podgotovka traktora i sazhalki k rabote. Tehnologii i mashiny dlja posadki kartofelja / URL: http://studwood.ru/1689662/agropromyshlennost/podgotovka_traktora_sazhalki_rabote_ (data obrashhenija 16.05.2020).

\section{Сведения об авторах \\ Принадлежность к организации}

Башкирев Анатолий Петрович - доктор технических наук, профессор Федерального государственно бюджетного образовательного учреждения высшего образования «Курская государственная сельскохозяйственная академия», Россия, г. Курск, e-mail: tmv46@mail.ru.

Шварц Анатолий Адольфович - доктор сельскохозяйственных наук, профессор Федерального государственно бюджетного образовательного учреждения высшего образования «Курская государственная сельскохозяйственная академия», Россия, г. Курск, e-mail: aashwarz@mail.ru.

Иванов Никита Андреевич - аспирант Федерального государственно бюджетного образовательного учреждения высшего образования «Курская государственная сельскохозяйственная академия», Россия, г. Курск, e-mail: juck0v.mih@yandex.ru.

\section{Author credentials}

\section{Affiliations}

Bashkirev Anatoly - Full Doctor of Technical Sciences, Professor of Federal State Budgetary Educational Institution of Higher Education "Kursk State Agricultural Academy”, Russia, Kursk, e-mail: tmv46@mail.ru.

Shvarts Anatoly Adolfovich - Full Doctor of Agricultural Sciences, Professor of Federal State Budgetary Educational Institution of Higher Education "Kursk State Agricultural Academy", Russia, Kursk, e-mail: aashwarz@mail.ru.

Ivanov Nikita - graduate student of Federal State Budgetary Educational Institution of Higher Education "Kursk State Agricultural Academy”, Russia, Kursk, e-mail: juck0v.mih@yandex.ru.

Поступила в редакцию (Received): 29.06.2020 Принята к публикации (Accepted): 20.08.2020 
УДК 637.115

DOI: $10.35887 / 2305-2538-2020-4-54-62$

\title{
ПРЕИМУЩЕСТВА РОБОТОВ ПЕРЕД ТРАДИЦИОННОЙ ТЕХНОЛОГИЕЙ ДОЕНИЯ КОРОВ
}

\author{
${ }^{1}$ Симонов Геннадий Александрович \\ ${ }^{1}$ Никифоров Владислав Евгеньевич \\ ${ }_{2}^{2}$ Филиппова Ольга Борисовна \\ ${ }^{1}$ ФГБУН «Вологодский научный иентр Российской академии наук» \\ ${ }^{2}$ ФГБНУ «Всероссийский научно-исследовательский институт \\ использования техники и нефтепродуктов в сельском хозяйстве»
}

\begin{abstract}
Реферат. Переход от механизированного труда на автоматические доильные системы и доильные роботы определяет новый уровень задач в современном молочном скотоводстве. На базе молочной фермы «Племзавод Родина» Вологодской области проведено изучение технологических особенностей доения с помощью роботов (VMS «DeLaval») в сравнении с традиционным доением. Для опытов были использованы коровы черно-пестрой породы. Изучали молочную продуктивность коров, сроки их использования в хозяйстве при беспривязном содержании и роботизированном доении, исследовали качество получаемого молока. Установлено, что при роботизированном доении на VMS «DeLaval» nовышается качество молока. Количество соматических клеток уменьшилось на 260-580 mыс. $/ \mathrm{cm}^{3}$, бактериальная обсемененность снизилась на 60 mыс. $/ \mathrm{cm}^{3}$ по сравнению с молоком от коров при традиционной технологии доения. При традиционной технологии доения товарность молока составляла $90 \%$, а при роботизированной - $97 \%$. Применение технологии роботизированного доения коров, у которых молочная продуктивность выше 7000 кг, позволило увеличить срок их хозяйственного использования на 1 лактацию. Удой у таких коров был выше на 7 - $10 \%$ по сравнению с традиционным доением. При традиционной технологии количество доений 8 сутки составляло в среднем 2,2, а при роботизированной технологии - 3,3. Сервис-период при роботизированном доении и беспривязном содержании у коров был короче на 50 дней по сравнению с традиционным способом.
\end{abstract}

Ключевые слова: роботизированная технология доения, коровы, молоко, качество, эффективность.

\section{ADVANTAGES OF ROBOTS OVER TRADITIONAL COW MILKING TECHNOLOGY}

${ }^{1}$ Simonov Gennady
${ }^{1}$ Nikivorov Vladislav
${ }^{2}$ Filippova Olga
${ }^{2}$ FSBSI “All-Russian Research Institute for Use of Machinery and Petroleum Products in Agriculture”

Abstract. The shift from mechanized labor to automatic milking systems and milking robots is setting a new level of challenge in modern dairy farming. On the basis of the dairy farm "Plemzavod Rodina" of the Vologda region, the study of technological features of milking using robots (VMS "DeLaval") in comparison with traditional milking was carried out. В опытах были использованы коровы черноnecmpoŭ nopodbl. We studied the milk productivity of cows, the timing of their use in the farm with free maintenance and robotic milking, and studied the quality of the resulting milk. It was found that the quality of milk increases during robotic milking on VMS "DeLaval". The number of somatic cells decreased by 260-580 thousand/ $\mathrm{cm}^{3}$, bacterial contamination decreased by 60 thousand/ $\mathrm{cm}^{3}$ compared to milk from cows with traditional milking technology. With traditional milking technology, the marketability of milk was $90 \%$, and with robotic milking - 97\%. The use of robotic milking technology for cows with a milk productivity of more than $7000 \mathrm{~kg}$ has increased the period of their economic use by 1 lactation. The milk yield of these cows was higher by 7-10\% compared to traditional milking. With traditional technology, the number of milking per day averaged 2.2, and with robotic technology-3.3. The service period for robotic milking and free keeping of cows was shorter by 50 days compared to the traditional method.

Keywords: robotic milking technology, cows, milk, quality, efficiency. 
Введение. Первоочередной задачей из всех существующих сегодня в отрасли молочного скотоводства является наращивание производства молока. Решается она различными путями увеличением продуктивности животных и совершенствованием технологии машинного доения. В настоящее время молочное животноводство России активно переходит от механизированного труда на автоматические доильные системы и доильные роботы.

Значительная трудоёмкость процесса доения и повышенные требования к качеству молока вызывало инвестиции в высокотехнологичное и наукоёмкое оборудование для молочных ферм. Это является объективной причиной для уменьшения доли ручного труда за счёт механизации процесса доения, а также перехода на полную автоматизацию. На долю машинного доения коров приходится от 40 до 65 \% всех трудовых затрат по обслуживанию животных.

Повышение эффективности производства молока путем технического перевооружения животноводческих предприятий определяет необходимые условия для внедрения роботизированных ферм с учетом современных методов производства и научной организацией труда. Создание крупных и современных ферм с комплексной механизацией основных и процессов происходит на основе технологической специализации, которая позволяет в наибольшем масштабе вести устойчивое производство молока и получать экономический эффект. Также эффективность молочной отрасли обеспечивается модернизацией основных технологических процессов, применения различных систем доения, способствующих рациональному использованию молочных коров. Это выражается в подборе пригодных к машинной технологии животных и комплектации по продуктивности. Широкое использование средств механизации и автоматизации на фермах промышленного типа сопровождается своеобразной стандартизацией отдельных технологических операций с замкнутым производственным циклом поточной системы содержания и обслуживания животных. Содержание и технология производства тесно связаны между собой, а затраты труда на единицу молочной продукции в условиях беспривязного содержания на $26 \%$ ниже по сравнению с привязным содержанием. Перевод на беспривязное содержание влечет за собой внедрение более прогрессивных технических и технологических элементов производства и организационных мер, позволяющих обслуживать значительное количество животных при минимальных затратах труда.

В современных условиях хозяйствования инвестиционные процессы, направленные в молочное животноводство и внедрение прогрессивных технологий позволяет обеспечить эффективность и повышение производства молока. В основу таких технологий положены беспривязный способ содержания коров и добровольная роботизированная система доения.

Полная механизация процесса доения предусматривает соблюдение особых требований к форме вымени, а также к скорости и продолжительности молокоотдачи у коров. Осуществлять отбор животных при комплектовании поголовья целесообразно по указанным параметрам, что позволяет придерживаться технологического графика работы фермы. На промышленных комплексах подбор коров по характеристикам процесса доения избежать вынужденных простоев всего высокопроизводительного оборудования доильных установок. Учет параметров скорости и продолжительности молокоотдачи в большей степени относится к использованию роботизированной технологии доения. При доении на роботе применяется система свободного передвижения животных, которые могут в любой момент подойти к доильному роботу, месту отдыха, а кормам и воде без всяких ограничений. Система свободного передвижения дает корове возможность самой выбирать время и частоту посещения доильного бокса.

Эффективность функционирования доильных установок зависит от их технических возможностей наиболее полно замещать ручной труд, удобства обслуживания, соответствия физиологическим характеристикам животных. Кроме того, нарушение требований основных операций доения может привести к заболеваниям коров и, как следствие, снижению качества молока и последующей выбраковке животных [1 - 3].

Материалы и методы исследований. Цель исследований заключалась в определении молочной продуктивности, качества получаемого молока и срока использования коров в условиях беспривязного содержания и роботизированного доения. Эксперимент был проведен на коровах черно-пестрой породы в передовом хозяйстве Вологодской области - АО «Племзавод Родина» Вологодского района, в котором применяется способ беспривязного содержания и роботизированная технология доения с использованием VMS «DeLaval». Изучали молочную продуктивность и индекс вымени коров, исследовали качественные показатели молока, определяли сроки использования коров в хозяйственной деятельности предприятия.

Результаты и их обсуждение. В Вологодской области на крупных промышленных комплексах в основном применяется способ беспривязного содержания. Технология доения - 
роботизированная с использованием VMS «DeLaval». В результате анализа основных характеристик изучаемых стад было установлено, что у большинства коров неравномерно развито вымя, это в свою очередь является серьезной проблемой на пути повышения эффективности роботизированного доения.

В настоящее время при комплектовании поголовья отбор коров для машинного доения осуществляется по показателям молочной продуктивности, скорости и продолжительности доения, которые, главным образом, зависят от морфофункциональных свойств вымени и индекса вымени. Эти показатели определяются с использованием специальных аппаратов раздельного доения каждой четверти вымени. Отбор животных по пригодности к машинному доению на фермах производится эпизодически с большим интервалом времени. Сам процесс отбора технологически очень трудоемкий. Основная сложность заключается в несовершенстве инструментальных средств. Например, для отбора коров для машинного доения может использоваться аппарат, с помощью которого специально определяют только процент удоя в передних четвертях вымени [4]. Однако при таком способе не учитывается степень воздействия доильного аппарата на организм коровы. По этой причине возникают вероятные ошибки при определении индекса вымени, который вносится в результат оценки пригодности коров к машинному доению. Необходимым условием отбора коров по пригодности к машинному доению является определение индекса вымени. Поэтому при доении роботом для объективной оценки коров необходимо более широко использовать автоматический контроль и обработку полученных данных, как общего удоя, так и по четвертям вымени раздельно. Существует способ, который позволяет учитывать индивидуальные особенности коров по уровню молокоотдачи каждой четверти во время доения на роботах [5].

Компьютерный анализ также уменьшает влияние человеческого фактора при сборе информации, позволяет снизить трудоемкость процесса обработки данных. В результате повышается точность оценки животных и определения эффективности целенаправленной селекции на пригодность к машинному доению.

На рисунке 1 представлена характеристика разового надоя молока при выборке из 162 коров обслуживаемых на двух роботах VMS «DeLaval». На рисунке 2 представлен суточный надой, а на рисунке 3 - индекс вымени коров. Кривые (рисунки 1 - 3) содержат ограниченные средние участки, которые находятся в области \pm б нормального распределения.

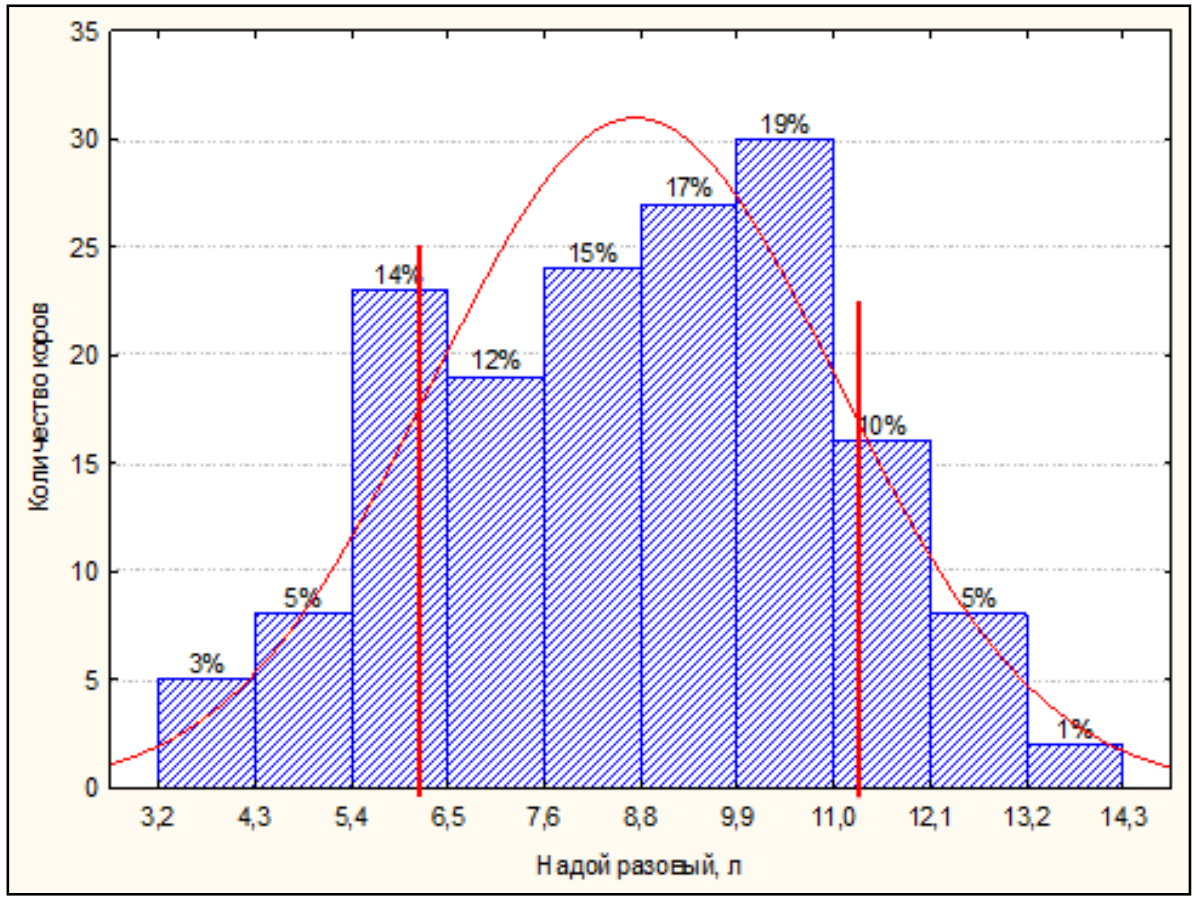

Рисунок 1 - Показатели разового надоя молока, л ( $\sigma=70$ \%) 


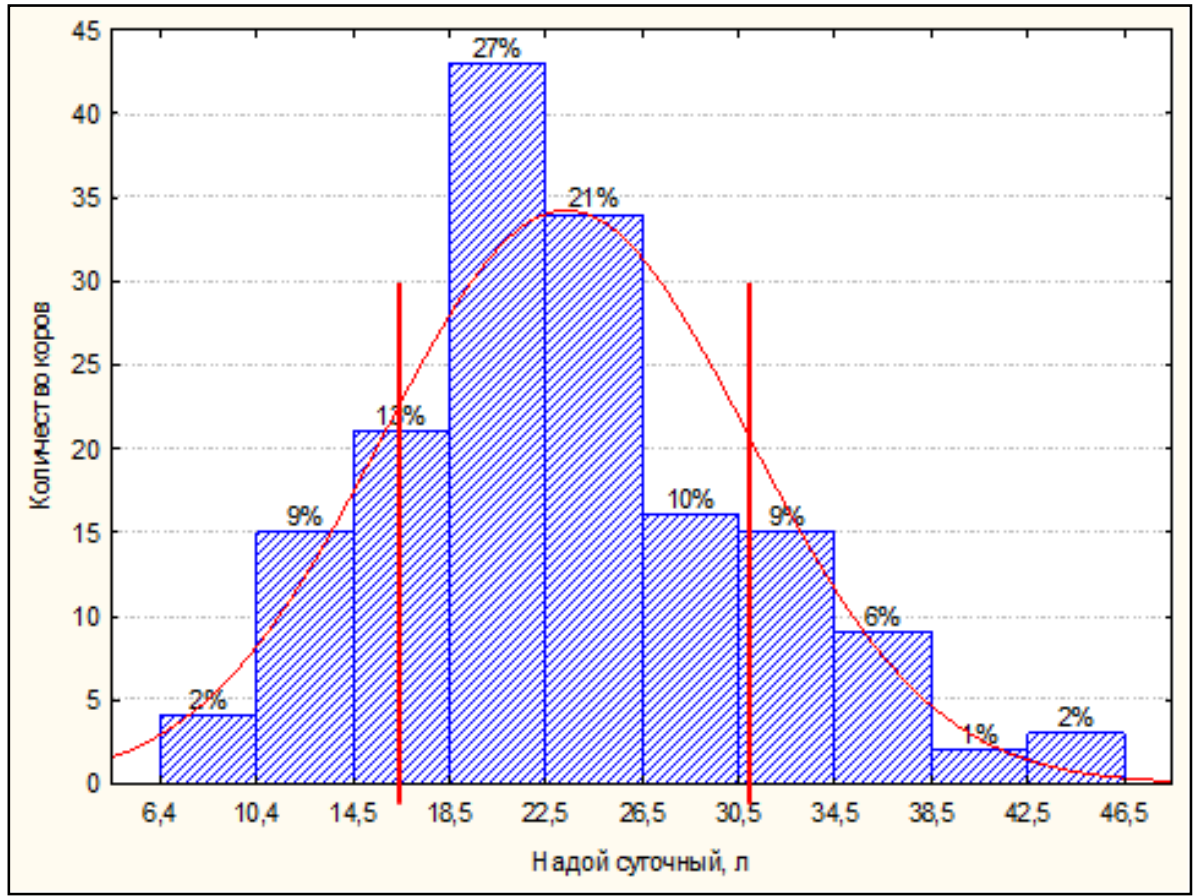

Рисунок 2 - Показатели суточного надоя молока, л $(\sigma=66$ \%)

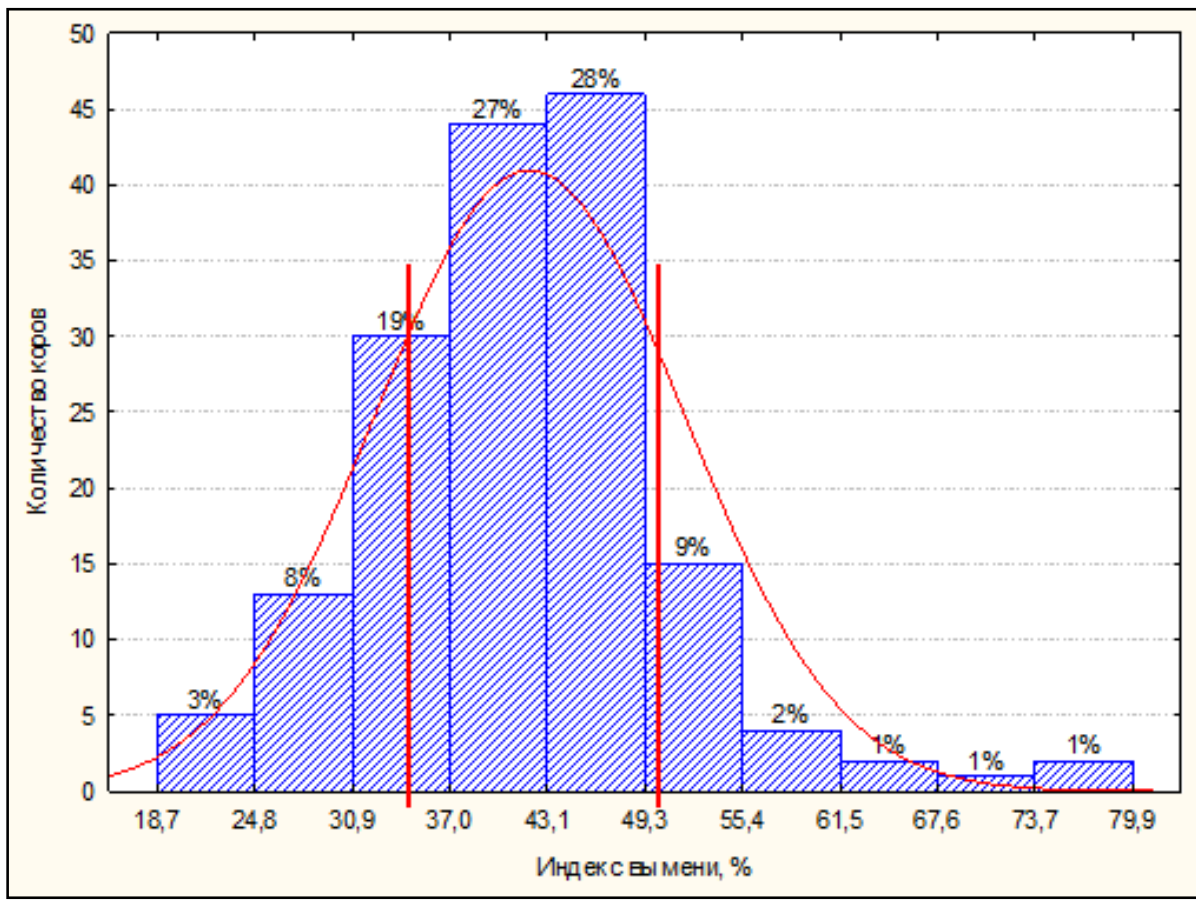

Рисунок 3 - Индекс вымени, \% $(\sigma=73 \%)$

Из анализа сравнительной оценки полученных значений установлено, что полученные значения морфофункциональных показателей вымени коров в области \pm н находятся в допустимых диапазонах требований для доения роботом. 
Основное преимущество использования доильных роботов заключается в наиболее полном исключении человеческого фактора при процессе доения. Все этапы работы таких установок выполняются в автоматическом режиме. Основными задачами роботизированной доильной системы являются следующие: идентификация коровы, подготовка ее к доению, установка доильных стаканов, доение и съём аппарата, обработка вымени, промывка механических частей доильной установки, которые соприкасаются с выменем, перекачка молока в охлаждающий танк. Охлаждение молока осуществляется в современных автоматизированных танках-охладителях DX/CE 3000 L, DX/CE 4500 L [6, 7].

Следует отметить, что отклонение в величине вакуума, плохая сосковая резина, отклонение от распорядка дня, несоблюдение техники доения неуклонно приводит к снижению удоя по всему поголовью на $6-10 \%$. При заболевании маститом у коров снижается удой на $12-30 \%$, неудовлетворительные условия содержания коров также снижают общую продуктивность до $10 \%$. Как показывает практика, строгое соблюдение технологической дисциплины при машинном доении коров дает возможность, повысить удой на $10-20 \%$ в равных условиях кормления и содержания [8,9].

На рисунке 4 показана скорость молокоотдачи у коров при доении на роботе в период 10 месяцев лактации.

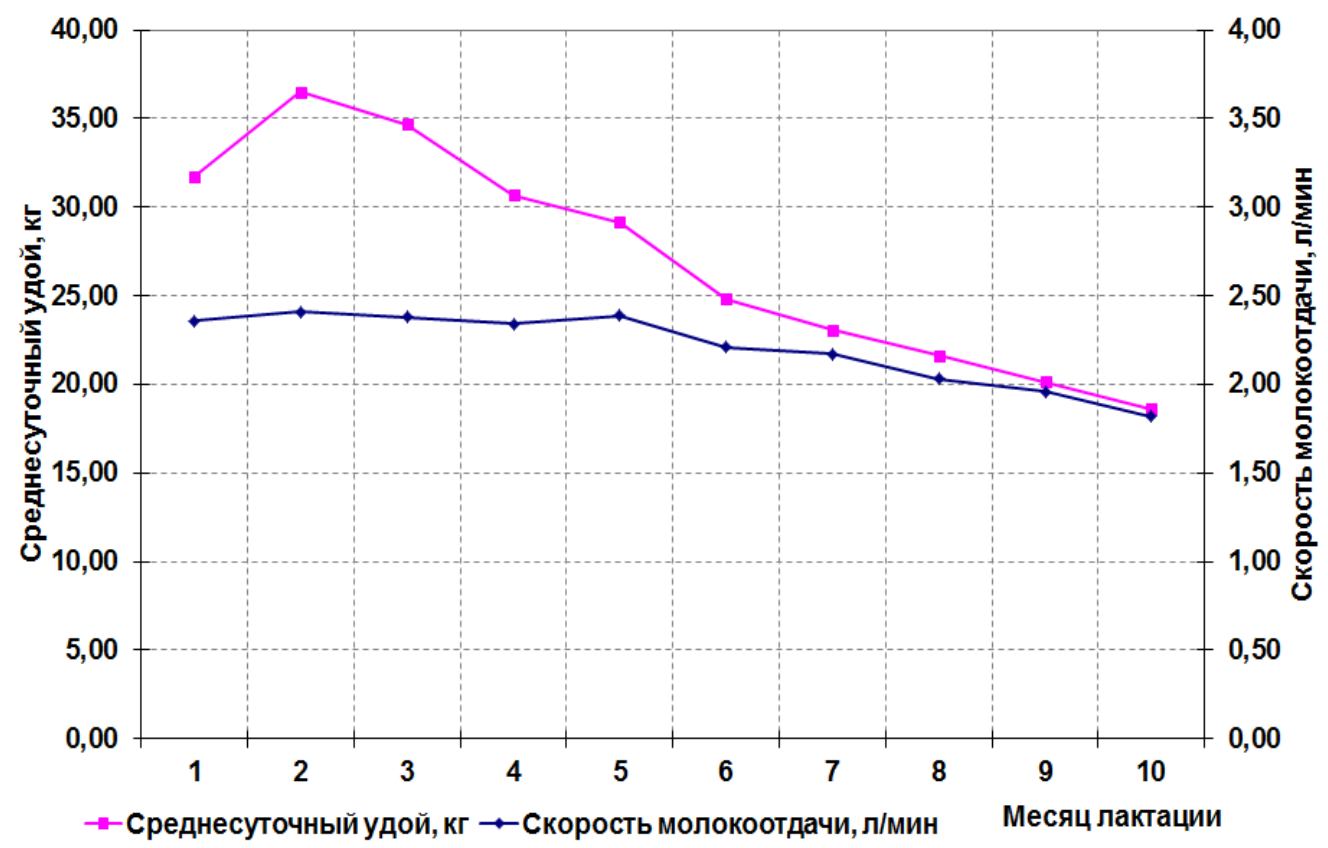

Рисунок 4 - Среднесуточный удой и скорость молокоотдачи коров в разрезе лактации

Скорость молокоотдачи впервые 5 месяцев изменяется незначительно и находится на уровне 2,36-2,41 л/мин. Средняя величина скорости молокоотдачи за лактацию 2,2 л/мин. Интенсивность молокоотдачи при хорошей подготовке животных к дойке может составлять 2,5-3,0 л/мин.

На рисунке 5 представлены показатели молочной продуктивности коров за 3 лактации при доении на роботе.

Динамика изменений молочной продуктивности коров при доении на роботе VMS в период трех последующих друг за другом лактаций схожа. Анализ кривых на рисунке 5 показывает, что в первой лактации начало снижения удоя приходится на 2-й и 3-й месяцы доения, что указывает на недостаточный раздой первотёлок. Разброс показателей максимальной продуктивности не превышает 2-3 л. В период второй и третьей лактации отмечается более интенсивное увеличение удоев до 3-го месяца включительно. Разброс показателей продуктивности увеличивается от 25 до 35 л. 


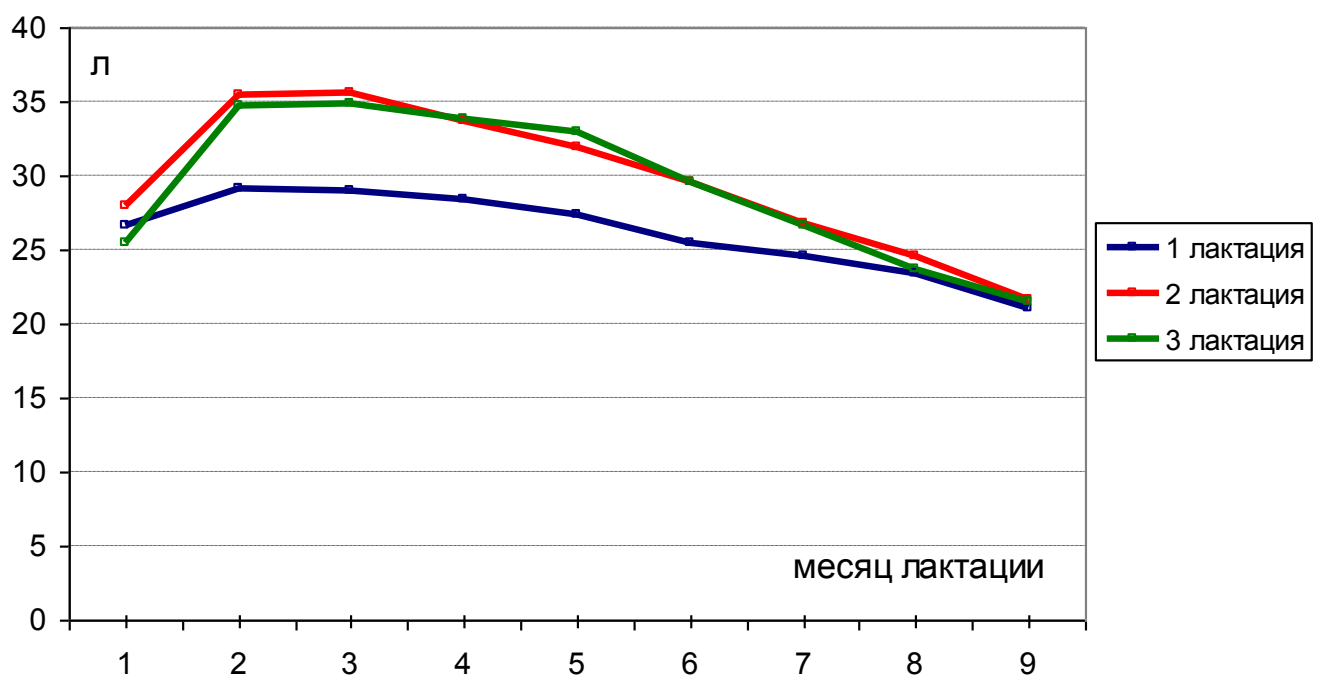

Рисунок 5 - Молочная продуктивность коров по 3 лактациям

Незначительный рост удоя коров первые месяцы лактации может быть связан также с недостаточным уровнем кормления. О положительном влиянии нормированных и сбалансированных рационов животных на их рост и развитие, продуктивность, качество получаемой продукции, воспроизводительную способность, переваримость и усвояемость корма указано в ряде работ [10-20], что необходимо учитывать при кормлении коров, особенно лактирующих.

Для повышения уровня молочной продуктивности животных на современных комплексах большое значение имеет совершенствование технологиий раздоя новотельных коров.

Сравнительный анализ традиционного и роботизированного доения коров показал, что роботизированная технология обеспечивает получение молока более высокого качества по сравнению традиционным доением коров. Это обусловлено тем, что при роботизированном доении контакт с молоком сводится к минимуму, чего нельзя сказать о доении на традиционных установках. В таблице 1 приведена характеристика показателей роботизированного и традиционного доения коров.

Таблица 1 - Характеристика показателей традиционного и роботизированного доения коров

\begin{tabular}{|c|c|c|}
\hline Показатель & $\begin{array}{c}\text { Доение традиционными } \\
\text { установками }\end{array}$ & $\begin{array}{l}\text { Доение роботами } \\
\text { VMS «DeLaval» }\end{array}$ \\
\hline Соматические клетки, тыс./cм ${ }^{3}$ & $350-700$ & $90-120$ \\
\hline Бактериальная обсемененность, тыс./см ${ }^{3}$ & Более 100 & До 40 \\
\hline Товарность молока, \% & 90 & 97 \\
\hline $\begin{array}{l}\text { Количество лактаций (продуктивность } \\
\text { более } 7000 \text { кг) }\end{array}$ & $3-4$ & $4-5$ \\
\hline $\begin{array}{l}\text { Продуктивность, } \pm \text { \% по отношению к } \\
\text { традиционной технологии доения }\end{array}$ & - & $+7-10$ \\
\hline Количество доений (среднее) & 2,2 & 3,3 и более \\
\hline Сервис-период, дни & 200 & 150 \\
\hline
\end{tabular}

Анализ данных таблицы 1 показывает, что при роботизированном доении на VMS «DeLaval» качество молока выше. Соматических клеток в нём было меньше на 260 - 580 тыс./ $\mathrm{cm}^{3}$, бактериальная обсемененность уменьшилась на 60 тыс./см³ по сравнению с молоком, полученном при традиционном доении. При этом товарность молока составила при традиционном доении $90 \%$, а при роботизированном - 97 \%. Коровы с продуктивностью выше 7000 кг молока за 
лактацию при роботизированном доении использовались в хозяйстве на 1 лактацию дольше. При этом удой у них был выше от 7 до $10 \%$ по сравнению с традиционной технологией доения. Количество доений в сутки составляло 3,3 в среднем, а при традиционном способе доения - 2,2, что благоприятно сказалось на молочной продуктивности. Сервис-период при роботизированном доении у коров был короче на 50 дней по сравнению с традиционной технологией.

Заключение. Проведенные исследования показали, что роботизированное доение с использованием VMS «DeLaval» позволяет повышать молочную продуктивность коров на 7 $10 \%$ и значительно улучшать качество получаемого молока по сравнению с традиционным способом доения. Кроме того, использование роботов при доении молочных коров и беспривязном содержании увеличивает срок их службы в хозяйстве на 1,1 лактации и позволяет сократить сервис-период на 50 дней.

\section{Список литературы}

1. Филиппова Е.Е. Автоматическое и роботизированное доение: сравнительный анализ // Молочная промышленность. - 2020. - № 7. - С. 61-63.

2. Кийко Е.И., Филиппова О.Б. Изменение качественных показателей молока при различных формах заболеваний маститом // Главный зоотехник. - 2013. - № 9. - С. 40-43.

3. Филиппова О.Б., Доровских В.И., Кийко Е.И. К методике физиологической оценки доильного оборудования // Наука в центральной России. - 2014. - № 6. - С. 53-60.

4. Способ отбора коров для машинного доения. Патент РФ № 2490887, приоритет от 27.08.2013. Опубл. 27.08.2013. Бюл. № 24.

5. Дадыкина А.Л., Наконечный А.А. Отбор проб и оценка качества молока в племенной работе. Усовершенствованная методика // Молочная промышленность. - 2020. - № 3. - С. 60-63.

6. Сереброва И.С., Углин В.К., Никифоров В.Е. Производство и качество молока при различных технологиях доения и способах содержания // FarmAnimals. - 2016. - № 2(12). - C. 10-12.

7. Особенности роботизированной технологии доения высокопродуктивных коров на современных комплексах / Е.А. Тяпугин, С.Е. Тяпугин, В.К. Углин, В.Е. Никифоров // Достижения науки и техники АПК. - 2015. - № 2. - С. 57-58.

8. Филиппова О.Б., Кийко Е.И. К проблеме выбраковки коров по степени пригодности к машинному доению // Главный зоотехник. - 2013. - № 5. - С. 14-17.

9. Филиппова О.Б., Кийко Е.И. Экономические аспекты нарушения правил машинного доения в промышленном производстве молока // Наука в центральной России. - 2013. - № 6. - С. 72-75.

10. Как повысить продуктивность бычков калмыцкой породы в аридной зоне / Д. Гайирбегов [и др.] // Комбикорма. - 2015. - № 12. - С. 63-64.

11. Витаминно-минеральный премикс для коров / В.С. Зотеев [и др.] // Животноводство. 1985. - № 5. - С. 45-46.

12. Воспроизводительная способность и состояние рубцового метаболизма коров при разной структуре рационов / А.П. Калашников [и др.] // Российская сельскохозяйственная наука. - 1984. № $11 .-$ C. 29.

13. Особенности минерального питания молочных коров / М. Магомедов [и др.] // Молочное и мясное скотоводство. - 1993. - № 1. - С. 11.

14. Энергосберегающая технология старосеяных пастбищ / И.В. Сереброва [и др.] // Достижения науки и техники АПК. - 2011. - № 1. - С. 48-50.

15. Использование комплексной минеральной смеси в кормлении коров / Г.А. Симонов // Вестник Российской академии сельскохозяйственных наук. - 1998. - № 3. - С. 60-61.

16. Влияние роботизированного доения на качество молока / Г.А. Симонов, В.Е. Никифоров, И.С. Сереброва [и др.] // Наука в центральной России. - 2020. - № 2(44). - С. 117-124.

17. Продуктивность коров и качество молока при использовании в их рационах ферросила / С. Тяпугин, Д. Гайирбегов, А. Федин [и др.] /// Молочное и мясное скотоводство. - 2011. - № 4. C. 19-21.

18. Сравнительная оценка технологических факторов, влияющих на производство и качество молока, при разных технологиях доения / Е.А. Тяпугин [и др.] // Доклады Российской академии сельскохозяйственных наук. - 2015. - № 3. - С. 50-53.

19. Фуражная зерносмесь, обогащенная азотом мочевино-формальдегидного соединения, в рационе крупного рогатого скота / Саранчина Е.Ф. [и др.] // Зоотехния. - 2007. - № 11. - С. 12-14.

20. Биоплексы микроэлементов в премиксах для телят / А. Фролов [и др.] // Молочное и мясное скотоводство. - 2010. - № 3. - С. 18-20. 


\section{References}

1. Filippova E.E. Avtomaticheskoe i robotizirovannoe doenie: sravnitel'nyj analiz // Molochnaja promyshlennost'. - 2020. - № 7. - S. 61-63.

2. Kijko E.I., Filippova O.B. Izmenenie kachestvennyh pokazatelej moloka pri razlichnyh formah zabolevanij mastitom // Glavnyj zootehnik. - 2013. - № 9. - S. 40-43.

3. Filippova O.B., Dorovskih V.I., Kijko E.I. K metodike fiziologicheskoj ocenki doil'nogo oborudovanija // Nauka v central'noj Rossii. - 2014. - № 6. - S. 53-60.

4. Sposob otbora korov dlja mashinnogo doenija. Patent RF № 2490887, prioritet ot 27.08.2013. Opubl. 27.08.2013. Bjul. № 24.

5. Dadykina A.L., Nakonechnyj A.A. Otbor prob i ocenka kachestva moloka v plemennoj rabote. Usovershenstvovannaja metodika // Molochnaja promyshlennost'. - 2020. - № 3. - S. 60-63.

6. Serebrova I.S., Uglin V.K., Nikiforov V.E. Proizvodstvo i kachestvo moloka pri razlichnyh tehnologijah doenija i sposobah soderzhanija // FarmAnimals. - 2016. - № 2(12). - S. 10-12.

7. Osobennosti robotizirovannoj tehnologii doenija vysokoproduktivnyh korov na sovremennyh kompleksah / E.A. Tjapugin, S.E. Tjapugin, V.K. Uglin, V.E. Nikiforov // Dostizhenija nauki i tehniki APK. - 2015. - № 2. - S. 57-58.

8. Filippova O.B., Kijko E.I. K probleme vybrakovki korov po stepeni prigodnosti k mashinnomu doeniju // Glavnyj zootehnik. - 2013. - № 5. - S. 14-17.

9. Filippova O.B., Kijko E.I. Jekonomicheskie aspekty narushenija pravil mashinnogo doenija $\mathrm{v}$ promyshlennom proizvodstve moloka // Nauka v central'noj Rossii. - 2013. - № 6. - S. 72-75.

10. Kak povysit' produktivnost' bychkov kalmyckoj porody v aridnoj zone / D. Gajirbegov [i dr.] // Kombikorma. - 2015. - № 12. - S. 63-64.

11. Vitaminno-mineral'nyj premiks dlja korov / V.S. Zoteev [i dr.] // Zhivotnovodstvo. - 1985. № 5. - S. 45-46.

12. Vosproizvoditel'naja sposobnost' i sostojanie rubcovogo metabolizma korov pri raznoj strukture racionov / A.P. Kalashnikov [i dr.] // Rossijskaja sel'skohozjajstvennaja nauka. - 1984. - № 11. - S. 29.

13. Osobennosti mineral'nogo pitanija molochnyh korov / M. Magomedov [i dr.] // Molochnoe i mjasnoe skotovodstvo. - 1993. - № 1. - S. 11.

14. Jenergosberegajushhaja tehnologija starosejanyh pastbishh / I.V. Serebrova [i dr.] // Dostizhenija nauki i tehniki APK. - 2011. - № 1. - S. 48-50.

15. Ispol'zovanie kompleksnoj mineral'noj smesi v kormlenii korov / G.A. Simonov // Vestnik Rossijskoj akademii sel'skohozjajstvennyh nauk. - 1998. - № 3. - S. 60-61.

16. Vlijanie robotizirovannogo doenija na kachestvo moloka / G.A. Simonov, V.E. Nikiforov, I.S. Serebrova [i dr.] // Nauka v central'noj Rossii. - 2020. - № 2(44). - S. 117-124.

17. Produktivnost' korov i kachestvo moloka pri ispol'zovanii v ih racionah ferrosila / S. Tjapugin, D. Gajirbegov, A. Fedin [i dr.] /// Molochnoe i mjasnoe skotovodstvo. - 2011. - № 4. - S. 19-21.

18. Sravnitel'naja ocenka tehnologicheskih faktorov, vlijajushhih na proizvodstvo i kachestvo moloka, pri raznyh tehnologijah doenija / E.A. Tjapugin [i dr.] // Doklady Rossijskoj akademii sel'skohozjajstvennyh nauk. - 2015. - № 3. - S. 50-53.

19. Furazhnaja zernosmes', obogashhennaja azotom mochevino-formal'degidnogo soedinenija, V racione krupnogo rogatogo skota / Saranchina E.F. [i dr.] // Zootehnija. - 2007. - № 11. - S. 12-14.

20. Biopleksy mikrojelementov v premiksah dlja teljat / A. Frolov [i dr.] // Molochnoe i mjasnoe skotovodstvo. - 2010. - № 3. - S. 18-20.

\section{Сведения об авторах}

\section{Принадлежность к организации}

Симонов Геннадий Александрович - доктор сельскохозяйственных наук, главный научный сотрудник Федерального государственного бюджетного учреждения науки «Вологодский научный центр Российской академии наук», Россия, г. Вологда, e-mail: sznii@list.ru.

Никифоров Владислав Евгеньевич - старший научный сотрудник Федерального государственного бюджетного учреждения науки «Вологодский научный центр Российской академии наук», Россия, г. Вологда, e-mail: sznii@list.ru.

Филиппова Ольга Борисовна - кандидат биологических наук, ведущий научный сотрудник, Федерального государственного бюджетного научного учреждения «Всероссийский научноисследовательский институт использования техники и нефтепродуктов в сельском хозяйстве», Россия, г. Тамбов, e-mail: filippova175@yandex.ru. 


\title{
Author credentials
}

Affiliations

Simonov Gennady - Doctor of Agricultural Sciences, Chief Researcher of Federal State Budgetary Institution of Sciences "Vologda Research Center of the Russian Academy of Sciences", Russia, Vologda, e-mail: sznii@list.ru.

Nikivorov Vladislav - Senior Researcher of Federal State Budgetary Institution of Sciences "Vologda Research Center of the Russian Academy of Sciences", Russia, Vologda, e-mail: sznii@list.ru.

Filippova Olga - Candidate of Biological Sciences, Leading Researcher of Federal State Budgetary Scientific Institution "All-Russian Research Institute for Use of Machinery and Petroleum Products in Agriculture”, Russia, Tambov, e -mail: filippova175@yandex.ru.

Поступила в редакцию (Received): 20.07.2019 Принята к публикации (Accepted): 20.08.2020

УДК 631.017.3: 621.181

DOI: $10.35887 / 2305-2538-2020-4-62-67$

\section{ОБОСНОВАНИЕ ПРИНЦИПА САМОРЕГУЛИРОВАНИЯ МОЩНОСТИ КОРМОВАРОЧНОГО КОТЛА НА ГАЗОВОМ ТОПЛИВЕ}

\author{
${ }^{1}$ Шувалов Анатолий Михайлович \\ ${ }^{1}$ Машков Алексей Николаевич \\ ${ }^{1}$ Чернов Денис Серафимович \\ ${ }^{1}$ ФБНУ «Всероссийский научно-исследовательский институт \\ использования техники и нефтепродуктов в сельском хозяйстве»
}

Реферат. В условиях постоянного роста тарифов на потребляемую энергию и конкуренции на внутреннем рынке у сельских товаропроизводителей существует проблема по снижению энергозатрат, так как они составляют существенную долю в себестоимости продукта. Особенно велики энергозатраты в тепловых процессах личных подсобных и фермерских хозяйств на отопление, приготовление кормов, пищи и др. Снизить энергозатраты на тепловые цели можно применением вместо дорогостоящей электроэнергии природного газа. Кроме того дополнительно экономии энергии можно добиться применением систем энергообеспечения тепловых процессов с автоматическим регулированием расхода газа пропориионально потребляемому тепловому потоку. Для обоснования иелесообразности применения автоматического регулирования расхода газа в тепловом проиессе приготовления кормов приведены расчеты составляющих теплового баланса в различных режимах работы кормоварочного котла и определены расходы энергии на эти изели. Так как в процессе разогрева корма разность температур между паром в паровой рубашке и температурой содержимого варочной ёмкости (тепловой напор) уменьшается, то полезный расход энергии так же уменьшается пропорционально тепловому напору. Результаты расчета расхода энергии на приготовление корма показывают, что применением средств автоматизации расхода газа пропориионально потребляемому тепловому потоку можно достигнуть экономии до 53,4 \%.

Ключевые слова: газ, кормоварочный котел, саморегулирование, мочность.

\section{SUBSTANTIATION OF THE PRINCIPLE OF SELF-REGULATION OF THE POWER OF THE FEEDING BOILER ON GAS FUEL}

\author{
${ }^{1}$ Shuvalov Anatoliy \\ ${ }^{1}$ Mashkov Alexey \\ ${ }^{1}$ Chernov Denis
}

${ }^{I}$ FSBSI “All-Russian Research Institute for Use of Machinery and Petroleum Products in Agriculture”

Abstract: In conditions of constant growth of tariffs for consumed energy and competition in the domestic market, rural producers face the problem of reducing energy costs, since they constitute a 
significant share in the cost of the product. Especially high energy consumption in the thermal processes of personal subsidiary and farm households for heating, preparation of feed, food, etc. Energy consumption for heating purposes can be reduced by using natural gas instead of expensive electricity. In addition, additional energy savings can be achieved by using energy supply systems for thermal processes with automatic gas flow control in proportion to the consumed heat flux. To substantiate the feasibility of using automatic control of gas consumption in the thermal process of preparing feed, calculations of the components of the heat balance in various operating modes of the feed boiler are given and energy consumption for these purposes is determined. Since in the process of heating the feed, the temperature difference between the steam in the steam jacket and the temperature of the contents of the brewing vessel (heat head) decreases, the useful energy consumption also decreases in proportion to the heat head. The results of calculating the energy consumption for the preparation of feed show that the use of automation means of gas consumption in proportion to the consumed heat flow can achieve savings of up to $53.4 \%$.

Keywords: gas, feed boiler, self-regulation, power.

Введение. В нашей стране с 2013 по 2020 годы реализуется государственная программа по поддержке животноводческих ферм, начинающих фермеров, личных подсобных хозяйств [1]. Одним из главных условий успешного функционирования животноводческой отрасли является применение современных технических средств для приготовления кормов. В себестоимости животноводческой продукции затраты на корма составляют $50-70$ \% [2]. Следует отметить, что крупные животноводческие фермы для приготовления кормов имеют широкий спектр высокотехнологического оборудования. В то же время мелкие производители такие, как ЛПХ и фермерские хозяйства, практически не обеспечены подобным оборудованием [2 - 4].

Сегодня в условиях постоянного роста тарифов на потребляемую энергию и конкуренции на внутреннем рынке, перед каждым сельским товаропроизводителем стоит вопрос по снижению себестоимости животноводческой продукции. В этой связи возникает потребность в экономном использовании энергии в каждом технологическом процессе. Особенно велики резервы по снижению энергозатрат в тепловых процессах, так как по-прежнему в личных подсобных хозяйствах (ЛПХ) и фермерских хозяйствах в тепловых процессах приготовления кормов и пищи используют в основном дорогостоящую электроэнергию вместо природного газа.

В ЛПХ и фермерских хозяйствах наиболее энергоёмким процессом является тепловая обработка (запаривание) кормов для животных и птицы. Кроме того в холодный период года тепловая энергия расходуется на подогрев воды для их поения. Из результатов мониторинга, проведённого в ЛПХ Знаменского района, следует: энергозатраты на содержание свиней составляют $14,5 \%$, крупного рогатого скота $-6,13 \%$, всего $20,63 \%$ от общих энергозатрат. При этом энергозатраты на тепловые процессы составляют 43 \%, на социально - бытовые цели (освещение, холодильники, телевизор и др.) - 36,37 \% [5]. Следует отметить, что снизить расход дорогостоящей электроэнергии в тепловых процессах приготовления кормов и тёплой воды можно использованием самого дешевого энергоносителя - природного газа. Существует широкий спектр варочных котлов различных по используемому энергоносителю (газ, электроэнергия), производительности и конструктивному исполнению. Общим недостатком их является отсутствие регулирования расхода энергии пропорционально потребляемому тепловому потоку, что приводит к излишнему её расходу [6].

Информационно-патентные исследования показывают, что существующая газовая автоматика применяется в основном для обеспечения безопасности процесса сжигания газовоздушной смеси в газогорелочном устройстве и для обеспечения нормальной работы котла. С точки зрения энергообеспечения варочного котла особенностью его является постепенное снижение потребляемого теплового потока пропорционально повышению температуры нагреваемого продукта в варочной емкости. Однако в существующих варочных котлах предусмотрены средства автоматизации со ступенчатым режимом регулирования мощности («включено-выключено»). Следует отметить, что при таком режиме регулирования мощности и при повышении температуры содержимого варочной емкости близко к закипанию продукта значительно увеличивается частота включения и отключения газогорелочного устройства. Такой режим работы газовой горелки снижает надежность работы, происходит повышенный износ средств 
автоматизации и устройств горелки, а также при частом включении возможен срыв пламени или неправильный розжиг, что может привести к тяжелым последствиям. И конечно, отсутствие плавного регулирования мощности горелки пропорционально потребляемому тепловому потоку сопровождается перерасходом газа. Кроме того для поддержания «тихого» кипения оператор должен дополнительно настраивать вручную топочное устройство, что увеличивает трудозатраты обслуживающего персонала. В этой связи является актуальным проведение научноисследовательской работы по обоснованию газоиспользующей системы энергообеспечения кормоварочного котла с саморегулированием мощности пропорционально температуре нагреваемого продукта в варочной ёмкости. К тому же в настоящее время в институте ведутся работы по созданию кормоварочного котла с регулированием расхода газа пропорционально потребляемому тепловому потоку $[7,8]$.

Результаты и их обсуждение. С целью обоснования целесообразности регулирования расхода газа пропорционально потребляемому тепловому потоку варочного котла проведен численный расчет составляющих теплового баланса в различных режимах его работы. В расчетах принято следующее допущение: КПД разрабатываемого варочного котла принят таким же как и для серийно выпускаемых котлов $(\eta=0,8)$. И так как в крестьянских хозяйствах часто потребность в кормах в течение летнего и зимнего периода, а также в зависимости от количества скота в различные периоды года, наличия различного сырья для переработки на корм, загрузка варочной ёмкости будет различной. В этой связи для анализа результатов расчета примем два варианта загрузки котла: 1. варочная ёмкость заполненана $100 \%$ и вариант 2 - на 50 \%.

В начальный период, когда металлоконструкции парогенератора, корпуса котла, варочной емкости холодные, то тепловой напор на всех нагревательных участках максимальный и потребляемый тепловой поток тоже максимальный (точка а рисунок 1).

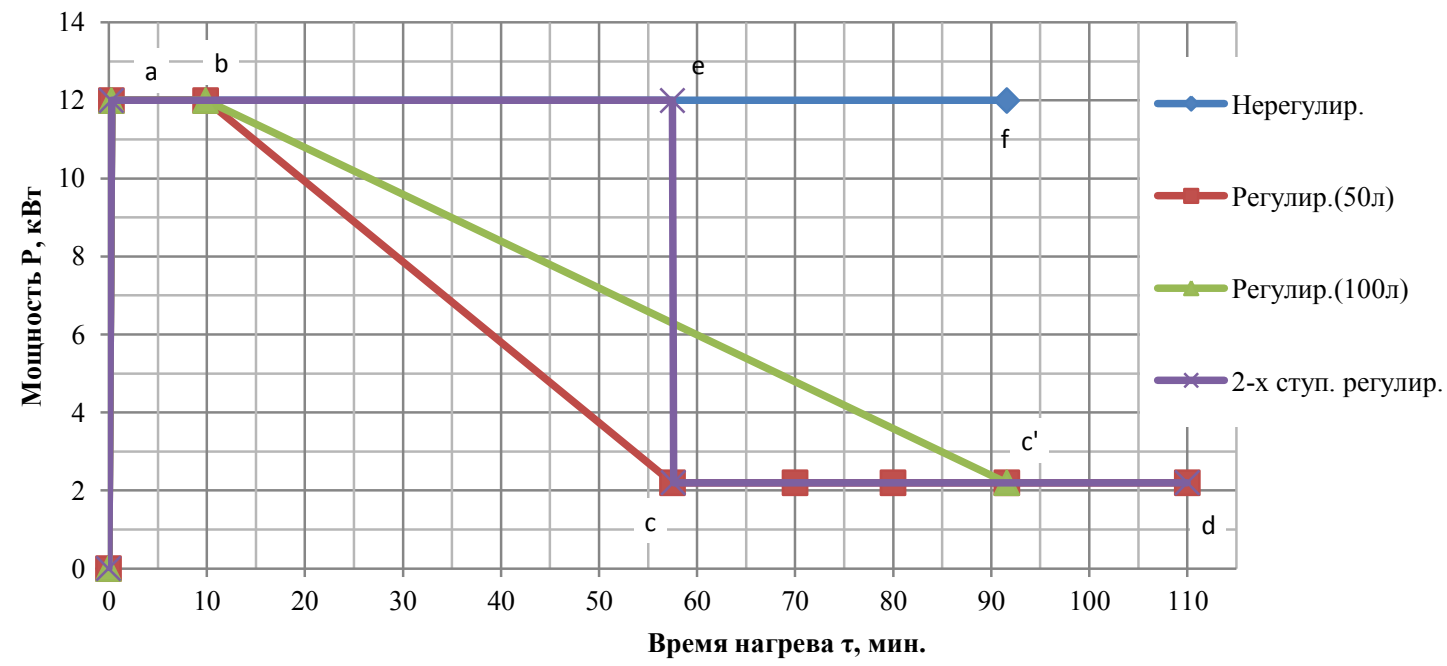

Рисунок 1 - Изменение мощности варочного аппарата при различных режимах регулирования мощности и загрузки варочной ёмкости

$$
\sum Q_{\text {мах }}=Q_{\mathrm{m}}^{\Pi \Gamma}+Q_{\mathrm{m}}^{\text {Корп }}+Q_{\mathrm{m}}^{\text {Вар.емк }}+Q_{\text {воды }}^{\text {Пв }}
$$

где $Q_{\mathrm{M}}^{\Pi \Gamma}, Q_{\mathrm{M}}^{\text {Корп }}, Q_{\mathrm{M}}^{\text {Вар.емк }}-$ максимальный тепловой поток на разогрев металлоконструкций

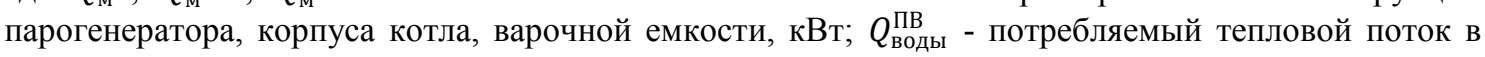
начальный период нагрева воды в пароводяной рубашке, кВт.

При нагреве металлоконструкции до максимума и воды (промежуточного теплоносителя) в водяной рубашке до закипания осуществляется частичное снижение потребляемого теплового потока (точка b рисунок 1).

В это время пар водяной рубашки начинает омывать поверхность варочной емкости, температура содержимого варочной емкости постепенно повышается от минимальной $\left(t_{\mathrm{B}}^{\min }\right)$ до 
максимальной $\left(t_{\mathrm{B}}^{\max }\right)$, а температурный напор в паровой рубашке будет снижаться от максимума до минимума. При этом потребляемый полезный тепловой поток на разогрев продукта через стенку варочной емкости будет изменяться от максимума (точка b)

до минимума (точка с рисунок 1)

$$
Q_{\text {пол }}^{\max }=k \cdot F \cdot\left(t_{\text {пара }}-t_{\mathrm{B}}^{\min }\right)
$$

$$
Q_{\text {пол }}^{\text {min }}=k \cdot F \cdot\left(t_{\text {пара }}-t_{\mathrm{B}}^{\max }\right) ;
$$

где $k$ - коэффициент теплопередачи, кВт/м ${ }^{2} \cdot{ }^{\circ} \mathrm{C} ; F-$ теплопередающая поверхность варочной емкости, $\mathrm{M}^{2} ; t^{\min }$ и $t^{\max }$ - минимальная и максимальная температура в варочной емкости, ${ }^{\circ} \mathrm{C}$.

На основе выше приведённых формул определена мощность котла в различных режимах, результаты расчета представлены на графике (рисунок 1). Из графика следует, что в начальный период разогрева продукта мощность котла одинаковая для всех режимов (линия a-b). Когда температура продукта повышается, то температурный напор между паром и продуктом уменьшается, следовательно и уменьшается потребляемый тепловой поток в режиме саморегулирования мощности (на графике линии: b-c и b-c'). В ручном режиме мощность котла постоянная в процессе приготовления корма (линия a-f), при двухступенчатом регулировании мощность изменяется по ломанной линии a-b-e-c-d. Если загрузка варочной ёмкости составляет 50 \% (то есть 50 л), то мощность достигает минимума при температуре продукта $60{ }^{\circ} \mathrm{C}$ (точка с), если же загрузка составляет 100 л, то минимум мощности наступит при $90{ }^{\circ} \mathrm{C}$ (точка с' рисунок 1 ).

В процессе кипения содержимого варочной ёмкости температура его будет постоянной и незначительно отличаться от температуры пара в паровой рубашке $\left(2-3{ }^{\circ} \mathrm{C}\right)$, то есть в этом случае потребляемый тепловой поток тоже минимальный (линия c-d на рис. 1). И так как при разогреве котла и продукта мощность уменьшается пропорционально снижению теплового напора, то при нерегулируемом режиме излишки теплоты будут выбрасываться вместе с отработанными газами. Как следует из графика тепловой поток и при ручном и при двухступенчатом регулировании всегда больше, чем при пропорциональном регулировании (линия a-b-c-d), следовательно и расход газа больше.

Расчеты показывают, что за счет применения плавно регулируемой системы энергообеспечения газоиспользующего кормоварочного котла достигается экономия энергии 53,4 \% при 100 \% загрузке варочной емкости и 58,2 \% при 50 \% загрузке.

Следовательно, с целью экономии энергии от сжигаемого газа необходимо применять систему автоматического регулирования расхода газа пропорционально потребляемому тепловому потоку в процессе разогрева и варки продукта.

Здесь следует добавить, что процесс приготовления продукта не заканчивается доведением жидкости в варочной емкости до кипения, а продолжается его варка, например, мяса $\tau_{\text {доп }}=1,5-$ 2 часа. Следовательно, потери энергии при нерегулируемом процессе с учетом времени варки увеличиваются еще в 1,5 - 2 раза.

Широко применяют в сельской местности для приготовления продукта в столовых газовые плиты, на которые ставят металлические бачки. Здесь дополнительные потери тепловой энергии от поверхности не теплоизолированного бачка в окружающую среду. Это в летний период значительно повышает температуру воздуха в служебных помещениях и создает невыносимые условия для обслуживающего персонала. Обслуживающий персонал открывает окна, образуется сквозняк и начинаются простудные заболевания [9].

Не менее важно отметить, что если в саморегулируемой системе энергообеспечения применить дополнительную цифровую автоматику для дистанционного включения в работу газовой горелки и программного отключения после завершения приготовления продукта, то будет достигнута значительная экономия затрат труда сельских работников.

\section{Выводы:}

1.Тепловой поток, потребляемый в процессе приготовления корма, всегда меньше в режиме саморегулирования, при 50\% загрузки варочной ёмкости минимум мощности достигается через 58 минут, при $100 \%$ загрузки - через 90 минут.

2. Применение в кормоварочном котле на газовом топливе энергетической системы с регулированием мощности газовой горелки пропорционально потребляемому тепловому потоку позволяет сократить расход газа в процессе приготовления корма на 53,4 \% по сравнению с ручным управлением. 


\section{Список литературы}

1. Государственная программа развития сельского хозяйства на 2013 - 2020 годы. -М., 2013. $388 \mathrm{c}$.

2. Хохрин С.Н. Корма и кормление животных. - Спб.. Лань, 2002. - 512c.

3. Мишуров Н.П. Приготовление кормов в фермерских хозяйствах. - М.. Росинформагротех, 2002. $-58 \mathrm{c}$.

4. Беляев М.И. Тепловое оборудование. - М.. Экономика, 1999. -559с.

5. Шувалов А.М., Калинин В.Ф., Набатов К.А. Мониторинг энергопотребления сельхозпредприятий Тамбовской области. Труды 6-й международной конференции. Энергообеспечение и энергосбережение в сельском хозяйстве. - М.. ГНУ ВИЭСХ, 2008. - с. 260-265.

6. Антуфьев В.Т. Концепция совершенствования газовых пищеварочных котлов. Научный журнал НИУ ИТМО. Серия «Процессы и аппараты пищеварочных производств», 2007. -№1.

7. Патент РФ № 2708097. СПК А47 27/06. Котёл кормоварочный/ Шувалов А.М.,Машков А.Н., Чернов Д.С.; заявитель и патентообладатель ФГБНУ ВНИИТиН опубл. 04.12.2019. Бюл. №34.

8. Шувалов А.М., Машков А.Н., Чернов Д.С., Шулаев Г.М., Вотановская Н.А. Стерилизация молочной ёмкости парогенератором с саморегулированием мощности. В сборнике: Повышение эффективности использования ресурсов при производстве сельскохозяйственной продукции новые технологии и техника нового поколения для растениеводства и животноводства. 18-я Международная научно - практическая конференция. 2015. - С.184 - 188.

9. Шувалов А.М., Машков А.Н., Чернов Д.С. Улучшение охраны труда и технической безопасности при приготовлении пищи и кормов в сельхозпредприятиях. ТрудыГОСНИТИ,2015. T.120. - C.102-104.

\section{References}

1. Gosudarstvennaja programma razvitija sel'skogo hozjajstva na 2013 - 2020 gody. -M., 2013. 388s.

2. Hohrin S.N. Korma i kormlenie zhivotnyh. - Spb.. Lan', 2002. - 512s.

3. Mishurov N.P. Prigotovlenie kormov v fermerskih hozjajstvah. - M.. Rosinformagroteh, 2002. $58 \mathrm{~s}$

4. Beljaev M.I. Teplovoe oborudovanie. - M.. Jekonomika, 1999. -559s.

5. Shuvalov A.M., Kalinin V.F., Nabatov K.A. Monitoring jenergopotreblenija sel'hozpredprijatij Tambovskoj oblasti. Trudy 6-j mezhdunarodnoj konferencii. Jenergoobespechenie i jenergosberezhenie $\mathrm{V}$ sel'skom hozjajstve. - M.. GNU VIJeSH, 2008. - s. 260-265.

6. Antuf'ev V.T. Koncepcija sovershenstvovanija gazovyh pishhevarochnyh kotlov. Nauchnyj zhurnal NIU ITMO. Serija «Processy i apparaty pishhevarochnyh proizvodstv», 2007. -№1.

7. Patent RF № 2708097. SPK A47 27/06. Kotjol kormovarochnyj/ Shuvalov A.M.,Mashkov A.N., Chernov D.S.; zajavitel' i patentoobladatel' FGBNU VNIITiN opubl. 04.12.2019. Bjul. №34.

8. Shuvalov A.M., Mashkov A.N., Chernov D.S., Shulaev G.M., Votanovskaja N.A. Sterilizacija molochnoj jomkosti parogeneratorom s samoregulirovaniem moshhnosti. V sbornike: Povyshenie jeffektivnosti ispol'zovanija resursov pri proizvodstve sel'skohozjajstvennoj produkcii - novye tehnologii i tehnika novogo pokolenija dlja rastenievodstva i zhivotnovodstva. 18-ja Mezhdunarodnaja nauchno prakticheskaja konferencija. 2015. - S.184-188.

9. Shuvalov A.M., Mashkov A.N., Chernov D.S. Uluchshenie ohrany truda i tehnicheskoj bezopasnosti pri prigotovlenii pishhi i kormov v sel'hozpredprijatijah. TrudyGOSNITI,2015. T.120. S.102 - 104.

\section{Сведения об авторах}

\section{Принадлежность к организации}

Шувалов Анатолий Михайлович - доктор технических наук, профессор, главный научный сотрудник Федерального государственного бюджетного научного учреждения «Всероссийский научно-исследовательский институт использования техники и нефтепродуктов в сельском хозяйстве», Россия, г. Тамбов, е-mail: vniiti@mail.ru.

Машков Алексей Николаевич - кандидат технических наук, ведущий научный сотрудник Федерального государственного бюджетного научного учреждения «Всероссийский научноисследовательский институт использования техники и нефтепродуктов в сельском хозяйстве», Россия, г. Тамбов, e-mail: vniiti@mail.ru. 
Чернов Денис Серафимович - кандидат технических наук, старший научный сотрудник Федерального государственного бюджетного научного учреждения «Всероссийский научноисследовательский институт использования техники и нефтепродуктов в сельском хозяйстве», Россия, г. Тамбов, e-mail: vniiti@mail.ru.

\title{
Author credentials
}

\section{Affiliations}

Shuvalov Anatoliy - Full Doctor of Technical Sciences, Professor, Chief Researcher of Federal State Budgetary Scientific Institution "All-Russian Research Institute for Use of Machinery and Petroleum Products in Agriculture”, Russia, Tambov, e-mail: vniiti@mail.ru.

Mashkov Alexey - Candidate of Technical Sciences, Leading Researcher of Federal State Budgetary Scientific Institution "All-Russian Research Institute for Use of Machinery and Petroleum Products in Agriculture”, Russia, Tambov, e-mail: vniiti@mail.ru.

Chernov Denis - Candidate of Technical Sciences, Senior Researcher of Federal State Budgetary Scientific Institution "All-Russian Research Institute for Use of Machinery and Petroleum Products in Agriculture”, Russia, Tambov, e-mail: vniiti@mail.ru

Поступила в редакцию (Received): 20.07.2020 Принята к публикации (Accepted): 20.08.2020

УДК 620.197.7:631.17

DOI: $10.35887 / 2305-2538-2020-4-67-76$

\section{ОЦЕНКА РАСХОДА СОRTЕС VPCI-368 И СОRTЕС VPCI-369 ДЛЯ ПРОТИВОКОРРОЗИОННОЙ ЗАЩИТЫ СЕЛЬСКОХОЗЯЙСТВЕННОЙ ТЕХНИКИ ОТ АТМОСФЕРНОЙ КОРРОЗИИ}

\author{
${ }^{1}$ Князева Лариса Геннадвевна \\ ${ }^{1}$ Дорохов Андрей Валерьевич \\ ${ }^{1}$ Курьято Николай Алексеевич \\ ${ }^{1}$ ФГБНУ «Всероссийский научно-исследовательский институт \\ использования техники и нефтепродуктов в сельском хозяйстве»
}

Реферат. Расход консервачионных материалов (КМ) влияет на стоимость противокоррозионной защиты и зависит от толщины защитной пленки. Изучали теоретический расход КМ на основе минеральньх масел: индустриального И-20А, трансформаторного ТКп, моторного $\mathrm{M10Г}_{2}(\kappa)$ (товарного и отработанного - ММО) и ингибиторов коррозии Соrtес VpCI368 и Cortec VpCI-369 в концентрации 3, 5, 7, 10 масс.\%. Покрытия получали окунанием образцов из стали Ст3 в КМ и последующим формированием в течение суток. Толщину пленки определяли гравиметрически. Максимальные величины для толщины пленок получили из составов на основе ММО, что соответствовало и максимальному защитному эффекту, минимальные - из трансформаторного масла. Значения толщины пленок получаемых из составов на основе И-20А и м10Г $(к)$ оказались близкими по величине. Наблюдали уменьшение толщинь пленок всех исследуемых КМ на стали с ростом температуры их нанесения и уменьшением концентрации ингибиторов. Зависимости толщины пленок минеральных масел от температуры носила практически линейный характер в диапазоне $40-70{ }^{\circ}$ С. По экспериментальным зависимостям, связывающим толщины пленок с кинематической вязкостью составов в логарифмических координатах, удовлетворительно соответствующим упрощенной формуле уравнения Левича, получены эмпирические уравнения. Установлено, что теоретический расход КМ из расчета получения покрытия заданной толщины на единицу площзади без учета безвозвратных потерь мало зависит от природы исследованных ингибиторов коррозии и не превышают $20-21$ г/м², а расход ингибитора не превышает $1,0-1,1$ г/м².

Ключевые слова: расход, консервационный материал, толщина, кинематическая вязкость 


\title{
EVALUATION OF CONSUMPTION CORTEC VPCI-368 AND CORTEC VPCI-369 FOR ANTI-CORROSION PROTECTION OF AGRICULTURAL EQUIPMENT FROM ATMOSPHERIC CORROSION
}

\author{
${ }^{1}$ Knyazeva Larisa $G$. \\ ${ }^{1}$ Dorokhov Andrey $V$. \\ ${ }^{1}$ Kuryato Nikolay $A$.
}

${ }^{\text {I} F S B S I ~ “ A l l-R u s s i a n ~ R e s e a r c h ~ I n s t i t u t e ~ f o r ~ U s e ~ o f ~ M a c h i n e r y ~ a n d ~ P e t r o l e u m ~ P r o d u c t s ~ i n ~ A g r i c u l t u r e ” ~}$

\begin{abstract}
The consumption of preservation materials (CM) affects the cost of anti-corrosion protection and depends on the thickness of the protective film. Theoretical consumption of CM based on mineral oils: industrial I-20A, transformer TKp, motor M10G 2 (k) (commercial and waste - MMO) and corrosion inhibitors Cortec VpCI-368 and Cortec VpCI-369 at a concentration of 3.5.7, 10 wt \% was studied. The coatings were obtained by dipping samples of steel St 3 in CM and subsequent formation during the day. The film thickness was determined gravimetrically. The maximum values for the film thickness were obtained from compositions based on MMO, which corresponded to the maximum protective effect, and the minimum values were obtained from transformer oil. The thicknesses of the films obtained from compositions based on I-20A and M10G2 (k) turned out to be close in value. A decrease in the thickness of the films of all studied CMs on steel with an increase in the temperature of their application and a decrease in the concentration of inhibitors was observed. The dependence of the thickness of mineral oil films on temperature was almost linear in the range $40-70{ }^{\circ} \mathrm{C}$. Empirical equations are obtained from the experimental dependences connecting the film thickness with the kinematic viscosity of the compositions in logarithmic coordinates, which satisfactorily corresponds to the simplified formula of the Levich equation. It has been established that the theoretical consumption of CM based on the production of a coating of a given thickness per unit area without taking into account irrecoverable losses depends little on the nature of the corrosion inhibitors studied and does not exceed $20-21 \mathrm{~g} / \mathrm{m}^{2}$, and the consumption of the inhibitor does not exceed $1.0-1.1 \mathrm{~g} / \mathrm{m}^{2}$.
\end{abstract}

Keywords: consumption, preservation material, thickness, kinematic viscosity.

Введение. При хранении на открытых площадках в нерабочий период огромный парк сельскохозяйственной техники подвергается коррозионному разрушению, из-за чего снижается ее работоспособность и ресурс, возрастают затраты на ремонт. Все это свидетельствует об актуальности изыскания наиболее эффективных способов противокоррозионной защиты. Не последнее место в определении эффективности противокоррозионной защиты сельскохозяйственной техники играет ее стоимость, в которую включается стоимость используемых материалов, срок службы, окупаемость производственных затрат и др. Номенклатура предлагаемых отечественным и зарубежным рынком консервационных материалов велика и разнообразна [1 - 11], в том числе и в ценовом отношении. Известно большое количество маслорастворимых ингибиторов коррозии $[1-10]$, которые находят наиболее широкое применение для защиты сельскохозяйственной техники от атмосферной коррозии. На стоимость защиты контактными материалами будет оказывать влияние их фактический расход, который состоит из суммы количества консервационного материала (КМ), расходуемого на получение пленки на поверхности металла необходимой толщины (теоретический расход) и дополнительного количества КМ, компенсирующего его потери при нанесении на сельскохозяйственную технику и оборудование.

\begin{tabular}{|c|c|c|c|c|c|c|}
\hline $\begin{array}{c}\text { Прогнозируемый } \\
\text { фактический расход } \\
\text { контактного } \\
\text { консервационного } \\
\text { материала (КМ) } \\
\text { (кг) }\end{array}$ & $=$ & $\begin{array}{c}\text { Количество КМ, расходуемое } \\
\text { на формирование покрытия с } \\
\text { заданной толщиной на единицу } \\
\text { площади } \\
\text { (теоретический расход) } \\
\left(\text { кг } / \mathrm{M}^{2}\right)\end{array}$ & $\mathrm{X}$ & $\begin{array}{c}\text { Площадь } \\
\text { защищаемой } \\
\text { поверхности } \\
\left(\mathrm{M}^{2}\right)\end{array}$ & + & $\begin{array}{c}\text { Количество КМ, } \\
\text { компенсирующее } \\
\text { его безвозвратные } \\
\text { потери при } \\
\text { нанесении } \\
\text { (кг) }\end{array}$ \\
\hline
\end{tabular}

Безвозвратные потери зависят от шероховатости и трудностей доступа к поверхности, погодных условий (особенно при консервации техники на открытых площадках), технологий нанесения. 
Толщина пленки консервационного материала на металлической поверхности в той или иной степени отвечает за долговечность покрытия, влияет на его защитную эффективность. Она, в свою очередь, зависит от вязкостно-температурных свойств используемого материала, природы масла и ингибитора. Недостаточная толщина пленки может привести к уменьшению срока эксплуатации покрытия и снижению его защитных свойств. В данной работе изучали теоретический расход консервационных материалов на основе Cortec VpCI-368 и Cortec VpCI-369 [12, 13] и минеральных масел для получения защитных покрытий на стали Ст3.

Материалы и методы. В работе использовали составы на основе индустриального И-20А (ГОСТ 20799-88), трансформаторного ТК $($ ТУ38.101890-81), моторного М10Г 2 (к) (ГОСТ 8581-78), товарного и отработанного ((ММО, наработка 200 мото-ч) масел при различных температурах. В качестве ингибиторов коррозии исследовали Cortec VpCI-368 [12] и Cortec VpCI-369 [13] в концентрации 3,5,7,10 масс.\%.

Кинематическую вязкость составов измеряли в интервале температур $20-70{ }^{0} \mathrm{C}$ с шагом $10^{0}$ С по ГОСТ 33-2000 (ИСО 3104-94). Толщина пленки определялась гравиметрически на образцах размером 30 х 30 х 2,5 мм. Для стандартизации условий использовали циркуляционный термостат серии LOIPLT-300.

Пленки консервационных материалов получали окунанием образцов из стали Ст3 в консервационный материал с последующим их подвешиванием для стекания излишков консервационного материала и формирования покрытия в течение суток. Толщину пленки $(\mathrm{h}, \mathrm{M \kappa м})$ определяли гравиметрически, используя формулу:

$$
\mathrm{h}=\frac{\Delta m \cdot 10^{-4}}{S \cdot \rho}
$$

где $\Delta m$ - изменение массы вещества до и после формирования покрытия, г; $\mathrm{S}$ - площадь

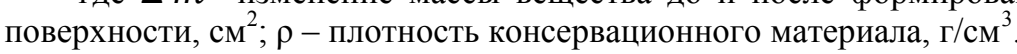

Теоретический расход материала определяли из расчета получения однослойного покрытия заданной толщины без учета безвозвратных потерь гравиметрически.

Ускоренные коррозионные испытания проводили в термовлагокамере Г-4 (ГОСТ 9.054-75), в 0,5 М растворе $\mathrm{NaCl}$ (ГОСТ 9.042-75). Электрохимические исследования проводили по методике, описанной в [14].

Результаты и их обсуждение. Толщина пленки консервационного материала на поверхности металла, зависит от температуры ее формирования и нанесения. На рисунке 1 показано влияние температуры на изменение вязкости исследуемых минеральных масел и толщины пленок, формирующихся при их нанесении на стали Ст3.

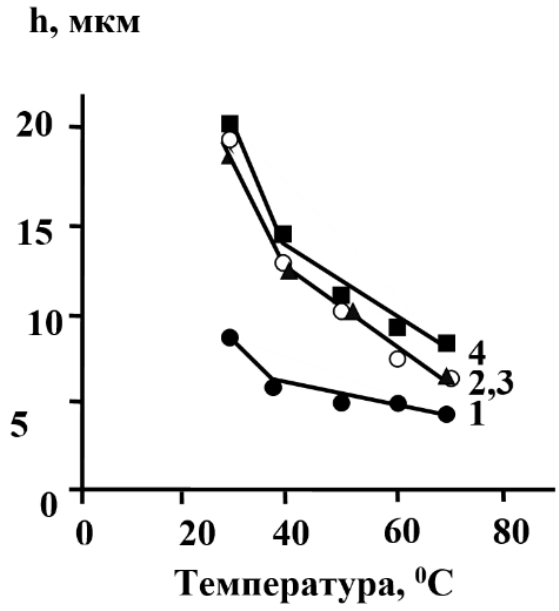

a)

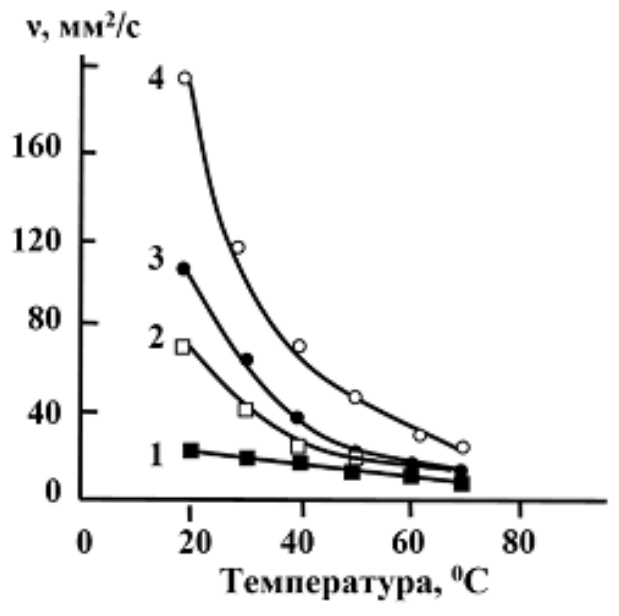

б)

Рисунок 1 - Зависимость толщины (h) формирующейся пленки на стали Ст3 (a) и кинематической вязкости (v) от температуры нанесения масла: 1- ТКп; 2 -И-20А; 3 - M10Г $2(\kappa) ; 4-$ МMO 
Наблюдали уменьшение толщины пленок всех исследуемых масел с ростом температуры их нанесения (рисунок 1а). Следует отметить, что значения толщин пленок, полученных при использовании масел И-20А и М10Г 2(к) практически совпадают. Как будет показано далее, это касается и пленок, полученных из исследуемых составов на их основе. Наиболее толстые пленки получаются из отработанных моторных масел (кривая 4, рисунок 1а), для которых характерна и более высокая вязкость (кривая 4, рисунок 1б), обусловленная увеличением в них концентрации продуктов старения [14 - 17], чему будет соответствовать наиболее высокий расход масла. Но для этих пленок характерна и более высокая защитная эффективность, которая составила при электрохимических поляризационных исследованиях $85 \%$, при гравиметрических в 0,5 М растворе $\mathrm{NaCl}-56 \%$, в термовлагокамере - $98 \%$. Хотя при натурно-стендовых исследованиях в открытой атмосфере покрытия неингибированного отработанного масла начинают активно смываться. Следует отметить, что зависимость толщины пленок минеральных масел от температуры носила практически линейный характер в диапазоне $40-70{ }^{0} \mathrm{C}$.

На рисунке 2 показана зависимость толщины пленки непосредственно от вязкости консервационного материала в логарифмических координатах. В этом случае получили практически линейные зависимости в диапазоне температур $30-70{ }^{0} \mathrm{C}$ с тангенсом угла наклона, зависящим от природы масла. В результате статистической обработки полученных данных (доверительная вероятность 0,95, критерий Стьюдента 2,365) получены следующие данные: для индустриального масла И-20А - 0,62; для ТКп - 0,66, для М10Г 2 (к) - 0,55, для ММО - 0,51. Относительная ошибка составила $15-20 \%$.
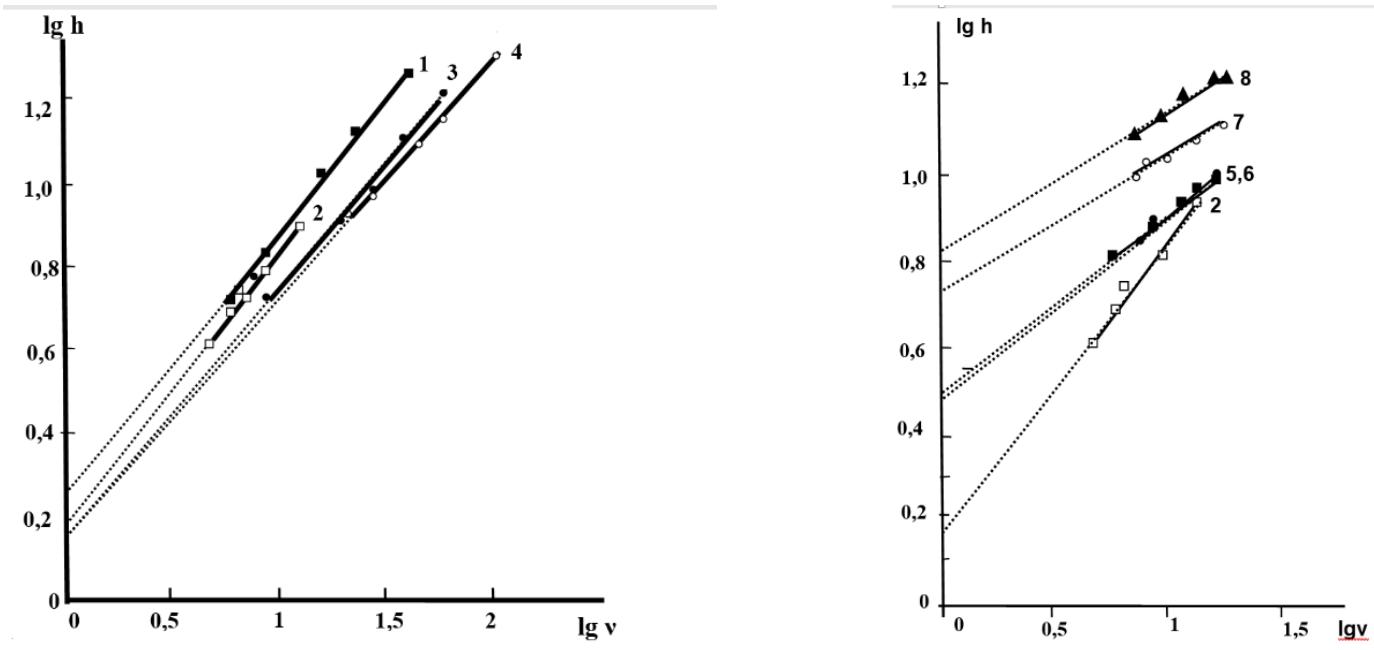

Рисунок 2 - Зависимость толщины пленки на стали от кинематической вязкости масел: 1- И-20А; 2 - ТКп; 3 - М10Г 2(к); 4 - ММО; консервационных материалов на основе ТКп и Cortec VpCI-368

Полученные экспериментальные зависимости удовлетворительно соответствуют упрощенной формуле уравнения Левича [18], связывающей толщины пленок покрытий с кинематической вязкостью.

$$
\operatorname{lgh}=\lg k+\gamma \cdot \lg v
$$

В этой формуле предполагается $\gamma=2 / 3$, что определяется тангенсом угла наклона прямых в координатах lgh-lgv. Нами получены близкие к теоретическим значения для исследуемых минеральных масел (рисунок 2, кривые 1-4). Коэффициент k, зависящий от плотности масла, поверхностного натяжения, ускорения свободного падения, можно определить по отрезку, отсекаемому на вертикальной оси. Определив отрезки, отсекаемые по оси ординат, были экспериментально получены следующие эмпирические уравнения (2-5), соответственно, для масел: индустриального И-20А (2); трансформаторного ТПк (3); моторных М10Г 2(к) товарного (4) и отработанного; $\mathrm{MMO}(5)$. 


$$
\begin{aligned}
& \lg h=0,26+0,62 \lg v_{\kappa} \\
& \lg h=0,20+0,66 \lg v_{\kappa} \\
& \lg h=0,17+0,55 \lg v_{\kappa} \\
& \lg h=0,17+0,5 \lg v_{\kappa}
\end{aligned}
$$

Уравнения $(2-5)$ позволяют по вязкости масла при различных температурах определить толщину получаемой пленки на стали.

Были экспериментально получены эмпирические уравнения для композиций на основе трансформаторного масла и Cortec VpCI-368 (6-9), соответственно, с концентрацией Cortec VpCI368, масс.\%: 3 (6); 5 (7); 7 (8); 10 (9).

$$
\begin{aligned}
& \lg h=0,50+0,47 \lg v_{\kappa} \\
& \lg h=0,50+0,47 \lg v_{\kappa} \\
& \lg h=0,73+0,50 \lg v_{\kappa} \\
& \lg h=0,82+0,50 \lg v_{\kappa}
\end{aligned}
$$

Следует отметить, что $\gamma$ был меньше, чем для исходного ТКп (рисунок 2, кривые 2 и 5-8). Относительная ошибка при определении этого коэффициента составила 15-20 \%, как и в случае использования непосредственно минеральных масел. Эмпирические уравнения для составов с концентрацией ингибитора 3 и 5 \% совпали, так как практически совпали прямые 5 и 6 на рисунке 2, отклонения по толщине покрытия находились в пределах ошибки эксперимента.

Для получения уравнений (6 - 9) потребовались исследования по изучению изменения вязкости составов на основе трансформаторного масла и ингибитора Cortec VpCI-368 и толщины формируемых ими пленок на стали Ст3 от температуры. Вязкостно-температурные зависимости приведены на рисунке3. Как следует из приведенных результатов, зависимости для составов с концентрацией ингибитора 3-7 масс.\% (кривые 1 - 3, рисунок 3) очень близки, зависимость для состава с концентрацией ингибитора 10 масс.\% отличается более существенно.

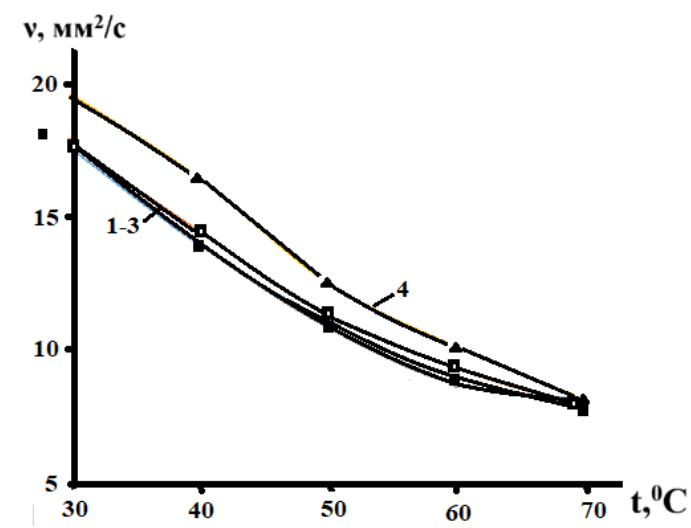

Рисунок 3 - Зависимость кинематической вязкости от температуры для составов на основе трансформаторного масла ТКп и Cortec VpCI-368, масс.\%: 1 - 3;2 - 5; 3 - 7; 4 - 10.

Результаты исследования влияния температуры нанесения композиций на основе трансформаторного масла ТКп и индустриального масла И-20A, ингибированных CortecVpCI-368 и CortecVpCI-369 на толщину образующейся на стали Ст3 пленки показаны в таблице 1. Они свидетельствуют о том, что с увеличением концентрации исследуемых ингибиторов в масле толщина пленки на поверхности металла возрастает, следовательно, исследуемые присадки обладают загущающим эффектом. С ростом температуры толщина пленок падает, как и для взятых для сравнения композиций на основе индустриального масла и ингибитора коррозии Эмульгин. В отличие от композиций с присадкой Эмульгин, резкого изменения толщины пленки при переходе концентрации ингибитора коррозии от 5 до 10 масс. \% при температуре $20-30{ }^{0} \mathrm{C}$ не наблюдается. Данные по толщине пленок, полученные для составов с Cortec VpCI-368 и Cortec VpCI-369 очень похожи. 
Таблица 1 - Влияние температуры составов на основе И-20А / ТКп на толщину образующейся пленки (мкм)

\begin{tabular}{|c|c|c|c|c|c|c|c|}
\hline \multirow{2}{*}{$\begin{array}{l}\text { Ингибитор } \\
\text { коррозии }\end{array}$} & \multirow{2}{*}{$\begin{array}{c}\text { Концентрация, } \\
\text { масс.\% }\end{array}$} & \multicolumn{6}{|c|}{ Температура, ${ }^{0} \mathrm{C}$} \\
\hline & & 20 & 30 & 40 & 50 & 60 & 70 \\
\hline \multicolumn{2}{|c|}{ Отсутствует } & $19,1 / 9,7$ & $19,0 / 8,0$ & $12,5 / 6,0$ & $10,9 / 5,4$ & $6,8 / 5,0$ & $5,1 / 4,2$ \\
\hline \multirow{4}{*}{$\begin{array}{c}\text { Cortec } \\
\text { VpCI-368 }\end{array}$} & 3 & $19,1 / 10,5$ & $18,5 / 9,5$ & $17,3 / 9,4$ & $16,3 / 8,8$ & $14,9 / 7,1$ & $14,3 / 6,3$ \\
\hline & 5 & $20,2 / 11,6$ & $18,8 / 10,7$ & $18,1 / 9,1$ & $16,4 / 8,9$ & $15,2 / 8,2$ & $14,6 / 7,1$ \\
\hline & 7 & $20,5 / 14,1$ & $19,5 / 13,7$ & $19,4 / 12,5$ & $17,8 / 11,7$ & $15,9 / 11,2$ & $15,7 / 9,8$ \\
\hline & 10 & $20,6 / 17,9$ & $20,2 / 17,1$ & $19,5 / 16,1$ & $18,0 / 14,7$ & $16,4 / 12,9$ & $16,3 / 12,8$ \\
\hline \multirow{4}{*}{$\begin{array}{c}\text { Cortec } \\
\text { VpCI-369 }\end{array}$} & 3 & $19,2 / 9,7$ & $18,2 / 9,8$ & $14,6 / 9,8$ & $14,5 / 9,7$ & $14,4 / 9,3$ & $14,3 / 9,0$ \\
\hline & 5 & $20,3 / 13,4$ & $16,8 / 12,5$ & $15,5 / 12,1$ & $15,1 / 11,7$ & $14,9 / 10,9$ & $14,7 / 10,5$ \\
\hline & 7 & $20,4 / 16,1$ & $17,9 / 15,2$ & $18,2 / 14,9$ & $17,8 / 14,0$ & $15,8 / 13,0$ & $15,6 / 12,5$ \\
\hline & 10 & $20,6 / 18,5$ & $20,5 / 17,5$ & $19,4 / 16,1$ & $18,0 / 15,8$ & $17,6 / 14,8$ & $17,3 / 13,8$ \\
\hline \multirow[t]{3}{*}{ Эмульгин } & 3 & 19,2 & 16,9 & 16,0 & 14,2 & 9,9 & 8,1 \\
\hline & 5 & 20,7 & 19,5 & 18,1 & 17,4 & 10,1 & 9,9 \\
\hline & 10 & 85,0 & 84,0 & 43,1 & 19,6 & 14,4 & 10,1 \\
\hline
\end{tabular}

Следует отметить, что исследуемые ингибиторы коррозии различаются по количеству летучих компонентов в своем составе. В Cortec VpCI-368, по данным производителя, их 35 - 40 \%, а в Cortec VpCI-369 их 1 - 5 \%. Но так как исследуется количество ингибиторов в маслах, не превышающее 10 \%, к тому образцы стали после погружения в консервационный материал выдерживали в течение суток (летучие компоненты при этом имели возможность испаряться), поэтому влияние различий в природе ингибиторов по количеству летучих компонентов на толщину получаемых пленок на стали Ст3 будет незначительным.

Составы на основе трансформаторного масла, в отличии от индустриального масла, обеспечили получение пленок, несколько меньшей толщины (таблица 1).

Проведенные электрохимические и гравиметрические исследования на примере составов на основе Cortec VpCI-368 и Cortec VpCI-369 в индустриальном масле И-20A, результаты которых представлены в таблице 2, показали наличие у них более высокой защитной эффективности, по сравнению с чистым индустриальным маслом, которая возрастала с ростом концентрации ингибитора коррозии. Оптимальной можно считать концентрацию Cortec VpCI-368 и Cortec VpCI369 в индустриальном масле И-20А 5-10 масс. \%.

Таблица 2 - Влияние концентрации составов на основе Cortec VpCI-368 и Cortec VpCI-369 в индустриальном масле И-20А на их защитную эффективность на стали Ст3 при электрохимических и гравиметрических испытаниях

\begin{tabular}{|c|c|c|c|c|c|c|}
\hline \multirow{4}{*}{$\begin{array}{c}\text { Концентрация } \\
\text { VрСlв } \\
\text { И-20A, } \\
\text { масс. \% }\end{array}$} & \multicolumn{6}{|c|}{ Защитная эффективность (Z), \% при исследованиях } \\
\hline & \multicolumn{3}{|c|}{$\mathrm{VpCl} 368$} & \multicolumn{3}{|c|}{$\mathrm{VpCl} 369$} \\
\hline & электрохимия & \multicolumn{2}{|c|}{ гравиметрия } & электрохимия & \multicolumn{2}{|c|}{ гравиметрия } \\
\hline & $\begin{array}{l}0,5 \mathrm{M} \\
\mathrm{NaCl} \\
\end{array}$ & $\begin{array}{l}0,5 \mathrm{M} \\
\mathrm{NaCl}\end{array}$ & $\begin{array}{l}\text { термовлаго } \\
\text { камера Г-4 }\end{array}$ & $\begin{array}{l}0,5 \mathrm{M} \\
\mathrm{NaCl}\end{array}$ & $\begin{array}{l}0,5 \mathrm{M} \\
\mathrm{NaCl}\end{array}$ & $\begin{array}{c}\text { термовлаго } \\
\text { камера Г-4 }\end{array}$ \\
\hline 0 & 41 & 21 & 41 & 41 & 21 & 45 \\
\hline 3 & 89 & 29 & 86 & 71 & 29 & 97 \\
\hline 5 & 96 & 69 & 97 & 87 & 69 & 99 \\
\hline 7 & 96 & 69 & 97 & 97 & 69 & 99 \\
\hline 10 & 96 & 69 & 98 & 98 & 69 & $\sim 100$ \\
\hline 100 & 89 & 81 & $\sim 100$ & 71 & 80 & $\sim 100$ \\
\hline
\end{tabular}

Значения толщин масляных пленок, полученных на стали при нанесении составов на основе моторного масла М10Г 2 (к) товарного и отработанного(ММO) показаны в таблице 3. Составы на основе индустриального И-20А и товарного моторного М10Г $($ (к) образуют на стали пленки, близкие по толщине. Толщина пленок, полученных из составов на основе ММО, ожидаемо выше за счет большей вязкости таких составов. 
Таблица 3 - Влияние температуры состава на основе товарного М-10Г (к) / ММО на толщину образующейся пленки

\begin{tabular}{|c|c|c|c|c|c|c|c|}
\hline \multirow{2}{*}{$\begin{array}{l}\text { Ингибитор } \\
\text { коррозии }\end{array}$} & \multirow{2}{*}{$\begin{array}{c}\text { Концентрация, } \\
\text { масс. } \%\end{array}$} & \multicolumn{6}{|c|}{ Температура, ${ }^{0} \mathrm{C}$} \\
\hline & & 20 & 30 & 40 & 50 & 60 & 70 \\
\hline \multicolumn{2}{|c|}{ Отсутствует } & $19,5 / 20,3$ & $17,1 / 20,3$ & $12,6 / 14,8$ & $8,3 / 11,2$ & $6,2 / 9,0$ & $6,0 / 8,5$ \\
\hline \multirow{4}{*}{$\begin{array}{l}\text { Cortec } \\
\text { VpCI-368 }\end{array}$} & 3 & $19,8 / 21,8$ & $16,5 / 19,0$ & $12,5 / 16,8$ & $11,7 / 14,5$ & $11,0 / 14,0$ & $10,7 / 10,9$ \\
\hline & 5 & $19,9 / 23,5$ & $16,8 / 19,8$ & $13,0 / 17,5$ & $12,5 / 15,0$ & $11,0 / 12,8$ & $10,6 / 11,4$ \\
\hline & 7 & $20,0 / 24,8$ & $17,2 / 21,5$ & $14,5 / 19,0$ & $13,3 / 16,3$ & $11,8 / 13,5$ & $10,7 / 11,8$ \\
\hline & 10 & $21,0 / 26,3$ & $18,5 / 23,1$ & $16,2 / 20,0$ & $14,5 / 17,5$ & $12,5 / 15,0$ & $11,0 / 12,1$ \\
\hline \multirow{4}{*}{$\begin{array}{l}\text { Cortec } \\
\text { VpCI-369 }\end{array}$} & 3 & $19,6 / 22,0$ & $19,5 / 15,9$ & $17,8 / 14,8$ & $14,2 / 13,0$ & $12,5 / 11,9$ & $11,0 / 10,2$ \\
\hline & 5 & $20,4 / 23,8$ & $19,7 / 21,8$ & $16,3 / 20,5$ & $14,5 / 17,5$ & $12,5 / 17,1$ & $11,1 / 13,8$ \\
\hline & 7 & $21,0 / 25,2$ & $20,3 / 22,9$ & $17,5 / 21,5$ & $15,0 / 16,0$ & $12,7 / 14,9$ & $11,0 / 14,1$ \\
\hline & 10 & $22,9 / 26,5$ & $22,5 / 23,1$ & $20,0 / 20,9$ & $17,5 / 11,5$ & $14 / 10,9$ & $11,6 / 14,1$ \\
\hline
\end{tabular}

В таблице 4 приведены данные по возможному теоретическому расходу исследуемых консервационных материалов. Расход консервационного материала мало зависит от природы

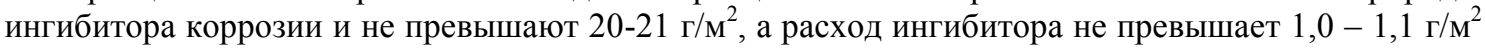
защищаемой поверхности.

Таблица 4 - Некоторые технологические параметры для консервационных материалов на основе Cortec VpCI-368 и Cortec VpCI-369

\begin{tabular}{|c|c|c|c|c|c|c|c|c|}
\hline \multicolumn{4}{|c|}{ Состав покрытия } & \multicolumn{2}{|c|}{ Температура Плотность } & \multirow{2}{*}{\begin{tabular}{|c|} 
Толщина \\
покрытия, \\
мкм
\end{tabular}} & \multicolumn{2}{|c|}{ Теоретический расход } \\
\hline Масло & мacc.\% & Ингибитор & мacc. $\%$ & нанесения & $\begin{array}{l}\mathrm{M} \\
/ \mathrm{M}^{3}\end{array}$ & & $\begin{array}{c}\mathrm{KM}, \\
\kappa \Gamma / \mathrm{M}^{2}\end{array}$ & $\begin{array}{c}\text { ингибитора, } \\
\Gamma / \mathrm{M}^{2}\end{array}$ \\
\hline \multirow[t]{6}{*}{ И-20А } & \multirow[t]{2}{*}{100} & \multirow[t]{2}{*}{-} & \multirow[t]{2}{*}{-} & 20 & \multirow[t]{2}{*}{880} & 19,1 & 0,017 & 0 \\
\hline & & & & 70 & & 5,1 & 0,004 & 0 \\
\hline & \multirow[t]{2}{*}{95} & \multirow{4}{*}{\begin{tabular}{|c|} 
CortecVpCI- \\
$368 /$ \\
CortecVpCI- \\
369
\end{tabular}} & \multirow[t]{2}{*}{5} & 20 & \multirow[t]{2}{*}{$902 / 872$} & $20,2 / 20,3$ & $0,018 / 0,018$ & $0,9 / 0,9$ \\
\hline & & & & 70 & & $14,6 / 14,7$ & $0,013 / 0,013$ & $0,7 / 0,7$ \\
\hline & \multirow[t]{2}{*}{90} & & \multirow[t]{2}{*}{10} & 20 & \multirow[t]{2}{*}{$882 / 879$} & $20,6 / 20,6$ & $0,018 / 0,018$ & $0,9 / 0,9$ \\
\hline & & & & 70 & & $16,3 / 17,3$ & $0,014 / 0,015$ & $0,7 / 0,8$ \\
\hline \multirow[t]{6}{*}{ ТКп } & \multirow[t]{2}{*}{100} & \multirow[t]{2}{*}{-} & \multirow[t]{2}{*}{ - } & 20 & \multirow[t]{2}{*}{885} & 9,7 & 0,009 & 0 \\
\hline & & & & 70 & & 4,2 & 0,004 & 0 \\
\hline & \multirow[t]{2}{*}{95} & \multirow{4}{*}{\begin{tabular}{|c|} 
CortecVpCI- \\
$368 /$ \\
CortecVpCI- \\
369
\end{tabular}} & \multirow[t]{2}{*}{5} & 20 & \multirow[t]{2}{*}{$867 / 864$} & $11,6 / 13,4$ & $0,010 / 0,012$ & $0,5 / 0,6$ \\
\hline & & & & 70 & & $7,1 / 10,5$ & $0,006 / 0,09$ & $0,3 / 0,5$ \\
\hline & \multirow[t]{2}{*}{90} & & \multirow[t]{2}{*}{10} & 20 & $864 / 876$ & $17,9 / 18,5$ & $0,015 / 0,016$ & $0,8 / 0,8$ \\
\hline & & & & 70 & & $12,8 / 13,8$ & $0,011 / 0,012$ & $0,6 / 0,6$ \\
\hline $\mathrm{M} 10 \Gamma_{2}(\kappa)$ & 100 & - & - & 20 & 900 & 19,5 & 0,017 & 0 \\
\hline & & & & 70 & & 6,0 & 0,005 & 0 \\
\hline & 95 & CortecVpCI- & 5 & 20 & $903 / 892$ & $19,9 / 20,4$ & $0,018 / 0,018$ & $0,9 / 0,9$ \\
\hline & & $368 /$ & & 70 & & $10,6 / 11,1$ & $0,010 / 0,010$ & $0,5 / 0,5$ \\
\hline & 90 & CortecVpCI- & 10 & 20 & $916 / 904$ & $21,0 / 22,9$ & $0,019 / 0,021$ & $1,0 / 1,0$ \\
\hline & & 369 & & 70 & & $11,0 / 11,6$ & $0,010 / 0,010$ & $0,5 / 0,5$ \\
\hline MMO & 100 & - & - & 20 & 850 & 20,3 & 0,017 & 0 \\
\hline & & & & 70 & & 8,5 & 0,007 & 0 \\
\hline & 95 & CortecVpCI- & 5 & 20 & $899 / 859$ & $23,5 / 23,8$ & $0,021 / 0,020$ & $1,1 / 1,0$ \\
\hline & & $368 /$ & & 70 & & $11,4 / 13,8$ & $0,010 / 0,012$ & $0,5 / 0,6$ \\
\hline & 90 & CortecVpCI- & 10 & 20 & $858 / 881$ & $17,9 / 18,5$ & $0,015 / 0,016$ & $0,8 / 0,8$ \\
\hline & & 369 & & 70 & & $12,8 / 13,8$ & $0,010 / 0,012$ & $0,5 / 0,6$ \\
\hline
\end{tabular}

Заключение. Таким образом, максимальные величины для толщины пленок получили из составов на основе МMO, что соответствовало их максимальному защитному эффекту, минимальные - из трансформаторного масла. Толщина пленок, получаемых из составов на основе И-20А, близка к значениям, полученным для моторного масла М10Г 2 (к). Наблюдали ожидаемое 
уменьшение толщины пленок всех исследуемых КМ на стали с ростом температуры их нанесения и уменьшением концентрации ингибиторов. Установлено, что зависимости толщины пленок минеральных масел от температуры носила практически линейный характер в диапазоне $40-70{ }^{\circ} \mathrm{C}$. Были получены эмпирические уравнения, связывающие толщину пленок и кинематическую вязкость для исследуемых минеральных масел и составов на основе трансформаторного масла и ингибитора Cortec VpCI-368, позволяющие на основе вязкости исследуемых консервационных материалов через толщину получаемого покрытия, определить их расход. Теоретический расход КМ из расчета получения покрытия заданной толщины на единицу площади без учета безвозвратных потерь для составов на основе Cortec VpCI-368 и Cortec VpCI-369 практически совпадал.

\section{Список литературы}

1. Научные основы, практика создания и номенклатура антикоррозионных консервационных материалов: Учеб. пособие для студентов хим. фак. ун-тов: Учеб. пособие для студентов вузов, обучающихся по специальности "Химия" / В. И. Вигдорович, Л. Е. Цыганкова, А. П. Поздняков, Н. В. Шель; М-во образования Рос. Федерации. Тамб. гос. ун-т им. Г. Р. Державина. - Тамбов: Изд-во ТГУ, 2001. - $192 \mathrm{c}$.

2. Yuanyuan Qian, Yongxin Li, Scott Jungwirth, Nicholas Seely, Yida Fang, Xianming Shi. The Application of Anti-Corrosion Coating for Preserving the Value of Equipment Asset in Chloride-Laden Environments: A Review // Int. J. Electrochem. Sci., 10 (2015). Pp. 10756 - 10780.

3. Tsygankova L.E., Vigdorovich V.I., Shel N.V., Dubinskaya E.V. Peculiarities of Protective Efficiency of Nitrogen Containing Inhibitors of Steel Corrosion //International Journal of Corrosion and Scale Inhibition. - 2013. - T. 2. - № 4. - C. 304-310.

4. Миронов Е.Б., Косолапов В.В., Тарукин Е.М., Маслов М.М. Оценка консервационных материалов для защиты от коррозии рабочих органов сельскохозяйственной техники // Вестник НГИЭИ. - 2015. - С. 1-13.

5. Прохоренков В.Д., Вигдорович В.И., Князева Л.Г. Доступные противокоррозионные материалы для защиты сельскохозяйственной техники от атмосферной коррозии // Практика противокоррозионной защиты. - 2003. - № 3 (29). - С. 51-54.

6. Князева Л.Г., Прохоренков В.Д., Остриков В.В., Чернышова И.Ю. Разработка консервационных материалов на основе отработанных масел // Химическое и нефтегазовое машиностроение. - 2002. - № 10. - С. 38-40.

7. Петрашев А.И., Князева Л.Г., Клепиков В.В. Технологические решения по консервации сельскохозяйственной техники отработанными моторными маслами // Труды ГОСНИТИ. - 2013. T. 112. - № 2. - С. 61-65.

8. Князева Л.Г., Петрашев А.И. К вопросу выбора консервационных материалов для защиты сельскохозяйственной техники // Наука в центральной России. - 2019. - № 1 (37). - С. 88-99.

9. Vigdorovich V.I., Knyazeva L.G., Tsygankova L.E., Ostrikov V.V., Petrashev A.I. Properties of Petroleum and Synthetic Oils as Bases for Anticorrosion Materials // Chemistry and Technology of Fuels and Oils. - 2019. - T. 55. - № 4. - C. 412-423.

10. http://cortecrus.ru/?yclid=4331878632232354672. Дата обращения 07.07.2020.

11. https://med-auto.com/auto-tips/the-best-anti-corrosion-materials-for-cars.html. Дата обращения 07.07.2020.

12. http://cortecrus.ru/antikorrozijnye-materialy/vremennye-pokrytiya/pokrytie-na-osnoverastvoritelya-dlya-maksimalno-dlitelnoj-zashchity-vpci-368.html. Дата обращения 07.07.2020.

13. http://cortecrus.ru/antikorrozijnye-materialy/vremennye-pokrytiya/pokrytie-na-osnove-masladlya-maksimalno-dlitelnoj-zashchity-vpci-369.html?yclid=4332080069410846604. Дата обращения 07.07.2020.

14. Князева Л.Г. Научные основы создания антикоррозионных консервационных материалов на базе отработавших нефтяных масел и растительного сырья / диссертация на соискание ученой степени доктора химических наук / ГОУВПО "Тамбовский государственный технический университет". Тамбов, 2012.

15. Прохоренков В.Д., Князева Л.Г., Остриков В.В., Вигдорович В.И. Носители защитной эффективности отработавших моторных масел // Химия и технология топлив и масел. 2006. № 1 (533). - С. 26-28.

16. Вигдорович В.И., Прохоренков В.Д., Князева Л.Г. Защитная эффективность продуктов очистки отработавших масел в условиях электрохимической коррозии стали // Технологии нефти и газа. - 2008. - № 4 (57). - С. 24-30. 
17. Вигдорович В.И., Прохоренков В.Д., Князева Л.Г., Епифанцев С.С. Защита от атмосферной коррозии отработанными маслами, ингибированными продуктами их очистки. Сообщение 4. Защитная эффективность ингибированных ПООМ отработанных масел в условиях влагонасыщения // Практика противокоррозионной защиты. - 2006. - № 2 (40). - С. 41-47.

18. Левич В. Физико-химическая гидродинамика. - М, Физматгиз,1959. - 669 с.

\section{References}

1. Nauchnye osnovy, praktika sozdaniya i nomenklatura antikorrozionnyh konservacionnyh materialov: Ucheb. posobie dlya studentov him. fak. un-tov: Ucheb. posobie dlya studentov vuzov, obuchayushchihsya po special'nosti "Himiya" / V. I. Vigdorovich, L. E. Cygankova, A. P. Pozdnyakov, N. V. SHel'; M-vo obrazovaniya Ros. Federacii. Tamb. gos. un-t im. G. R. Derzhavina. - Tambov: Izd-vo TGU, 2001. - $192 \mathrm{~s}$.

2. Yuanyuan Qian, Yongxin Li, Scott Jungwirth, Nicholas Seely, Yida Fang, Xianming Shi. The Application of Anti-Corrosion Coating for Preserving the Value of Equipment Asset in Chloride-Laden Environments: A Review // Int. J. Electrochem. Sci., 10 (2015). Rr. 10756 - 10780.

3. Tsygankova L.E., Vigdorovich V.I., Shel N.V., Dubinskaya E.V. Peculiarities of Protective Efficiency of Nitrogen Containing Inhibitors of Steel Corrosion//International Journal of Corrosion and Scale Inhibition. - 2013. - T. 2. - № 4. - S. 304-310.

4. Mironov E.B., Kosolapov V.V., Tarukin E.M., Maslov M.M. Ocenka konservacionnyh materialov dlya zashchity ot korrozii rabochih organov sel'skohozyajstvennoj tekhniki // Vestnik NGIEI. - 2015. - S. 1-13.

5. Prohorenkov V.D., Vigdorovich V.I., Knyazeva L.G. Dostupnye protivokorrozionnye materialy dlya zashchity sel'skohozyajstvennoj tekhniki ot atmosfernoj korrozii // Praktika protivokorrozionnoj zashchity. - 2003. - № 3 (29). - S. 51-54.

6. Knyazeva L.G., Prohorenkov V.D., Ostrikov V.V., CHernyshova I.YU. Razrabotka konservacionnyh materialov na osnove otrabotannyh masel // Himicheskoe i neftegazovoe mashinostroenie. - 2002. - № 10. - S. 38-40.

7. Petrashev A.I., Knyazeva L.G., Klepikov V.V. Tekhnologicheskie resheniya po konservacii sel'skohozyajstvennoj tekhniki otrabotannymi motornymi maslami // Trudy GOSNITI. - 2013. T. 112. № 2. - S. 61-65.

8. Knyazeva L.G., Petrashev A.I. K voprosu vybora konservacionnyh materialov dlya zashchity sel'skohozyajstvennoj tekhniki // Nauka v central'noj Rossii. - 2019. - № 1 (37). - S. 88-99.

9. Vigdorovich V.I., Knyazeva L.G., Tsygankova L.E., Ostrikov V.V., Petrashev A.I. Properties of Petroleum and Synthetic Oils as Bases for Anticorrosion Materials // Chemistry and Technology of Fuels and Oils. - 2019. - T. 55. - № 4. - S. 412-423.

10. http://cortecrus.ru/?yclid=4331878632232354672. Data obrashcheniya 07.07.2020.

11. https://med-auto.com/auto-tips/the-best-anti-corrosion-materials-for-cars.html.

Data obrashcheniya 07.07.2020.

12. http://cortecrus.ru/antikorrozijnye-materialy/vremennye-pokrytiya/pokrytie-na-osnoverastvoritelya-dlya-maksimalno-dlitelnoj-zashchity-vpci-368.html. Data obrashcheniya 07.07.2020.

13. http://cortecrus.ru/antikorrozijnye-materialy/vremennye-pokrytiya/pokrytie-na-osnove-masladlya-maksimalno-dlitelnoj-zashchity-vpci-369.html?yclid=4332080069410846604. Data obrashcheniya 07.07.2020.

14. Knyazeva L.G. Nauchnye osnovy sozdaniya antikorrozionnyh konservacionnyh materialov na baze otrabotavshih neftyanyh masel i rastitel'nogo syr'ya / dissertaciya na soiskanie uchenoj stepeni doktora himicheskih nauk / GOUVPO "Tambovskij gosudarstvennyj tekhnicheskij universitet". Tambov, 2012.

15. Prohorenkov V.D., Knyazeva L.G., Ostrikov V.V., Vigdorovich V.I. Nositeli zashchitnoj effektivnosti otrabotavshih motornyh masel // Himiya i tekhnologiya topliv i masel. 2006. - № 1 (533). - S. 26-28.

16. Vigdorovich V.I., Prohorenkov V.D., Knyazeva L.G. Zashchitnaya effektivnost' produktov ochistki otrabotavshih masel v usloviyah elektrohimicheskoj korrozii stali // Tekhnologii nefti i gaza. 2008. - № 4 (57). - S. 24-30.

17. Vigdorovich V.I., Prohorenkov V.D., Knyazeva L.G., Epifancev S.S. Zashchita ot atmosfernoj korrozii otrabotannymi maslami, ingibirovannymi produktami ih ochistki. Soobshchenie 4. Zashchitnaya effektivnost' ingibirovannyh POOM otrabotannyh masel v usloviyah vlagonasyshcheniya // Praktika protivokorrozionnoj zashchity. - 2006. - № 2 (40). - S. 41-47.

18. Levich V. Fiziko-himicheskaya gidrodinamika. - M, Fizmatgiz,1959. - 669 s. 


\title{
Сведения об авторах
}

Принадлежность к организации

Князева Лариса Геннадьевна - доктор химических наук, доцент, главный научный сотрудник Федерального государственного бюджетного научного учреждения «Всероссийский научно исследовательский институт использования техники и нефтепродуктов в сельском хозяйстве», Россия, г. Тамбов, e-mail: Knyazeva27@mail.ru.

Дорохов Андрей Валерьевич - младший научный сотрудник Федерального государственного бюджетного научного учреждения «Всероссийский научно-исследовательский институт использования техники и нефтепродуктов в сельском хозяйстве», Россия, г. Тамбов, е-mail: dorokhov.andryusha@mail.ru.

Курьято Николай Алексеевич - лаборант-исследователь Федерального государственного бюджетного научного учреждения «Всероссийский научно-исследовательский институт использования техники и нефтепродуктов в сельском хозяйстве», Россия, г. Тамбов, е-mail: cskasparta@yandex.ru.

\section{Author credentials}

\section{Affiliations}

Knyazeva Larisa G. - Full Doctor of Chemical Sciences, Associate Professor, Chief Researcher of Federal State Budgetary Scientific Institution "All-Russian Research Institute for Use of Machinery and Petroleum Products in Agriculture”, Russia, Tambov, e-mail: Knyazeva27@mail.ru.

Dorokhov Andrey V. - Junior Researcher of Federal State Budgetary Scientific Institution "All Russian Research Institute for Use of Machinery and Petroleum Products in Agriculture", Russia, Tambov, e-mail: dorokhov.andryusha@mail.ru.

Kuryato Nikolay A - Research laboratory assistant of Federal State Budgetary Scientific Institution "All-Russian Research Institute for Use of Machinery and Petroleum Products in Agriculture", Russia, Tambov, e-mail: cskasparta@yandex.ru.

Работа выполнена при поддержке РНФ, проект № 18-16-00006 This work was supported by RNF, project No. 18-16-00006

Поступила в редакцию (Received): 20.07.2020 Принята к публикации (Accepted): 21.08.2020

УДК 621.822.6.004.67:668.3:631.3.02

DOI: $10.35887 / 2305-2538-2020-4-76-84$

\section{ИССЛЕДОВАНИЕ ТРИБОЛОГИЧЕСКИХ ПАРАМЕТРОВ И КОНТАКТНЫХ НАПРЯЖЕНИЙ В ПОДШИПНИКАХ КАЧЕНИЯ АВТОМОБИЛЕЙ}

\author{
${ }^{1}$ Ли Роман Иннакентьевич \\ ${ }^{1}$ Киба Мария Романовна \\ ${ }^{1}$ Быконя Андрей Николаевич \\ ${ }^{l}$ ФГБОУ ВО «Липеиякий государственньй технический университет»
}

Реферат. Увеличение долговечности подшипников качения автомобилей позволяет снизить затраты на ремонт техники и увеличить время безотказной работы. Большое распространение получил метод восстановления изноченных посадочных отверстий в корпусных деталях автомобилей нанесением покрытий из раствора эластомера. Установлено, что наличие слоя полимерного нанокомпозита в посадочном отверстии приводит к перераспределению нагрузки с центрального, наиболее нагруженного тела качения на соседние с ним за счет деформации кольца подшипника, увеличивается площадь пятна контакта нагруженных тел с дорожками качения из-за большей деформации поверхности дорожек качения в подиипниках с покрытием из полимерного нанокомпозита в сравнении со стандартным подшипником. Это приводит к снижению контактных напряжений и увеличивается ресурс подиипников. Предложена оригинальная методология исследования трибологических параметров и контактных напряжений в подшипниках качения и конструкция стенда для проведения вышеупомянутых 
исследований. Методология включает исследование коэффицчиента постели, коэффицииета Кирхгофа, построение тарировочного графика зависимости площади пятна контакта нагруженного тела с дорожкой качения от радиальной нагрузки, исследование распределения нагрузки и контактных напряжений между телами качения при радиальном нагружении подшипника с полимерным покрытием. Приведены результаты исследования контактных напряжений в подшипниках с посадками, восстановленными полимерным нанокомпозитом. Проведенные экспериментальные исследования показывают корректность разработанной методологии исследования трибологических параметров и контактных напряжений $в$ подиипниках качения.

Ключевые слова: подшипник, контакт, нагрузка, площадь, напряжение, долговечность, полимерный нанокомпозит.

\title{
RESEARCH OF TRIBOLOGICAL PARAMETERS AND CONTACT STRESSES IN CAR ROLLING BEARINGS
}

\author{
${ }^{1}$ Lee Roman \\ ${ }^{1}$ Kiba Maria \\ ${ }^{I}$ FSBEI HE "Lipetsk State Technical University" \\ ${ }^{1}$ Bykonya Andrew
}

\begin{abstract}
Increasing the durability of rolling bearings of automobiles allows reducing the cost of repairing equipment and increasing the uptime. The method of restoring worn-out landing holes in car body parts by applying coatings from an elastomer solution is widely used. It has been established that the presence of a polymer nanocomposite layer in the bore hole leads to a redistribution of the load from the central, most loaded rolling element to its adjacent due to deformation of the bearing ring, the contact area of the loaded bodies with the raceways increases due to greater deformation of the surface of the raceways in the bearings coated with a polymer nanocomposite in comparison with a standard bearing. This reduces contact stresses and increases bearing life. An original methodology for the study of tribological parameters and contact stresses in rolling bearings and a bench design for the aforementioned studies are proposed. The methodology includes the study of the bed coefficient, the Kirchhoff coefficient, the construction of a calibration graph of the dependence of the contact area of the loaded body with the raceway on the radial load, the study of the load distribution and contact stresses between the rolling bodies under radial loading of a polymer-coated bearing. The results of a study of contact stresses in bearings with seats reduced by a polymer nanocomposite are presented. The conducted experimental studies show the correctness of the developed methodology for the study of tribological parameters and contact stresses in rolling bearings.
\end{abstract}

Keywords: bearing, contact, load, area, stresses, longevity, bearing, polymeric nanocomposite.

Введение. Долговечность подшипников качения в значительной мере определяется напряжениями в зоне контакта нагруженных тел с дорожками качения. Ресурс деталей подшипника $L$ при работе в условиях точечного контакта (радиальный шарикоподшипник) обратно пропорционален максимальному контактному давлению $\sigma_{0}[1]$

$$
L \approx \frac{1}{\sigma_{0}^{9}} .
$$

Как следует из формулы (1) незначительное снижение контактного напряжения существенно увеличит ресурс деталей и соответственно подшипника качения. При восстановлении изношенных посадочных отверстий подшипников качения в корпусных деталях полимерными материалами достигается многократное увеличение ресурса подшипников. Причины следующие: 1) перераспределение нагрузки с центрального, наиболее нагруженного на соседние боковые тела качения благодаря деформации кольца подшипника с полимерным покрытием; 2) увеличение площади пятна контакта нагруженных тел с дорожками качения из-за большей деформации поверхности дорожек качения в подшипниках с полимерным покрытием в сравнении со стандартным подшипником [2 - 3]. Поэтому исследования трибологических параметров и контактных напряжений в подшипниках качения с полимерным покрытием являются 
актуальными, так как позволят разработать технические решения, направленные на увеличение ресурса подшипниковых узлов при восстановлении.

Цель исследований. В Липецком государственном техническом университете разработан стенд оригинальной конструкции для исследования контактных напряжений и долговечности подшипниковых узлов автомобилей [4]. Радикальные изменения конструкции стенда привели к необходимости разработки оригинальной методологии исследования трибологических параметров, контактных напряжений и долговечности подшипников качения. Исследование выполнено при финансовой поддержке РФФИ в рамках научного проекта № 19-38-90227 19.

Результаты и их обсуждение. Методология включает исследование коэффициента постели $K$, коэффициента Кирхгофа $\eta$ построение тарировочного графика зависимости площади пятна контакта нагруженного тела с дорожкой качения $S$ от радиальной нагрузки $P$, исследование распределения нагрузки и контактных напряжений между телами качения при радиальном нагружении подшипника с полимерным покрытием.

Стенд для испытания подшипников качения на долговечность при статическом нагружении (рисунок 1) включает ручной гидравлический насос 1, создающий давление в масляной магистрали, который сообщается с помощью гидравлических шлангов 2 и трубопроводов с двумя радиальными и одним осевым узлами нагружения.

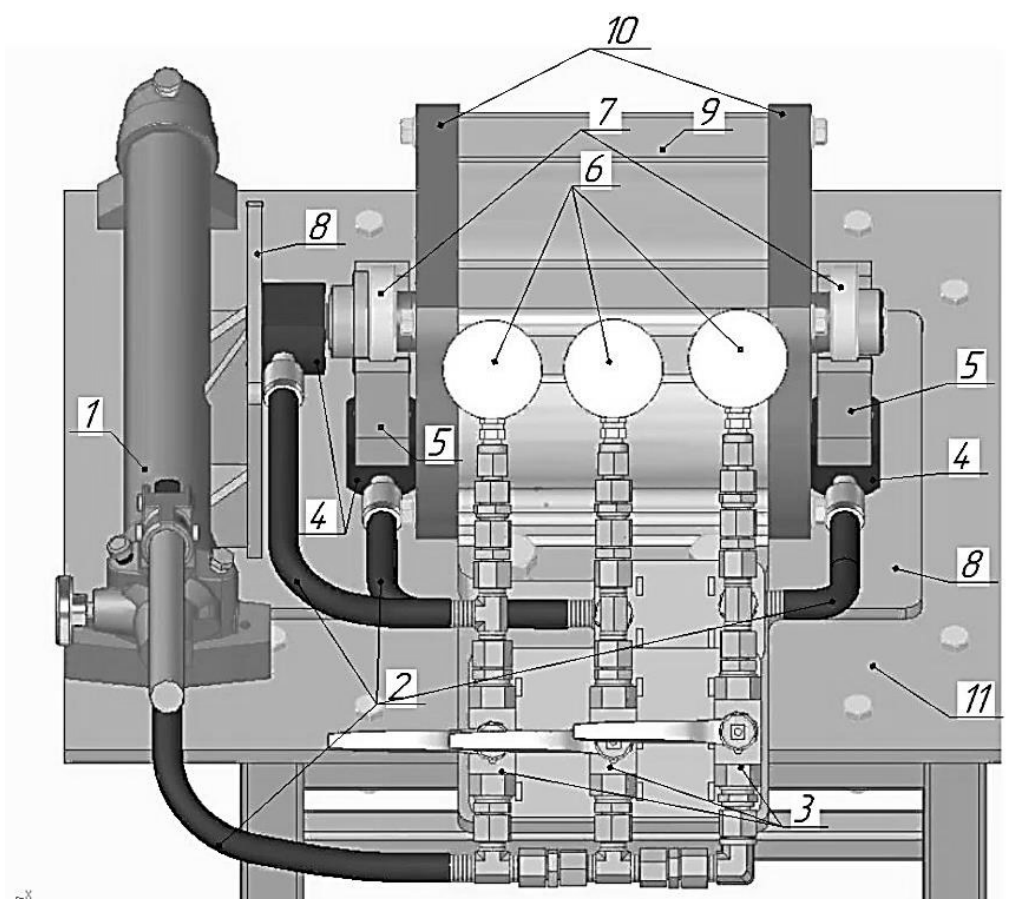

Рисунок 1 - Стенд для испытания подшипников качения на долговечность при статическом нагружении [4]

Радиальный узел нагружения состоит из двухходового крана 3, контрольного манометра 6, регистрирующего радиальную нагрузку на подшипник, гидроцилиндра 4, крепящегося болтами к основанию опорной пластины 8, установленной на раме стенда 11 , нагрузочной вилки 5 , обеспечивающей передачу нагрузки от штока гидроцилиндра на вспомогательный подшипник 7, вал и испытываемый подшипник в щите 10 ассинхронного электродвигателя 9.

Осевой узел нагружения состоит из двухходового крана 3, контрольного манометра 6, регистрирующего осевую нагрузку на подшипник, гидроцилиндра 4, крепящегося болтами к вертикальному кронштейну опорной пластины 8, корпуса с упорным подшипником и упорной втулки, обеспечивающих осевую нагрузку вал и испытываемый подшипник.

Для исследования коэффициента постели $K$, коэффициента податливости упругого основания 
$k_{n}$, коэффициента Кирхгофа $\eta$, построения тарировочного графика зависимости площади пятна контакта нагруженного тела с дорожкой качения $S$ от радиальной нагрузки $P$ демонтировали опорную пластину 8 и установленное на ней оборудование. На опорную раму стенда установили монтажный стол на четырех опорных стойках. На монтажный стол при помощи болтов закрепили гидроцилиндр, который соединили с ручным гидравлическим насосом с помощью гидравлических шлангов и трубопроводов, с двухходовым краном и контрольным манометром, регистрирующим радиальную нагрузку на штоке гидроцилиндра. Разработана и изготовлена нагрузочная вилка (рис. 2). Нагрузочная вилка при помощи резьбы заворачивается в резьбовое отверстие в штоке гидроцилиндра. Нагрузка от гидроцилиндра на шарик передается нагрузочной пластиной 1. Нагрузочная пластина имеет сферическое углубление, в котором размещается и фиксируется шарик.

Поверочная плита 2-1-250×250 ГОСТ $10905-75$ опирается на раму стенда. На плиту устанавливают исследуемую металлическую пластину с полимерным покрытием, которое будет сопрягаться с поверочной плитой. На металлическую поверхность пластины укладывают полосу копировальной бумаги марки МВ-16 ГОСТ 489-88. Шарик при радиальном нагружении взаимодействует с металлической поверхностью пластины и оставляет отпечаток пятна контакта на копировальной бумаге. Измерения пятна контакта осуществляют с помощью микроскопа МПБ2, который имеет цену деления 0,05 мм и обеспечивает 24-х кратное увеличение.

Коэффициент Кирхгофа ๆ рассчитывают по формуле

$$
\eta=\frac{D_{\Pi \kappa}^{3}}{3 P D_{ш}}
$$

где $D_{\text {пк }}-$ диаметр пятна контакта, мм; $P$ - нагрузка шарик, $\mathrm{H} ; D_{\text {ш }}-$ диаметр шарика.

Для исследования коэффициента постели $K$, при нагружении шариком пластины, проводят измерение деформации последней с помощью измерительной головки 1 МИГ с ценой деления 0,001 мм, которая закреплена на штативе. Повторность измерений трехкратная.

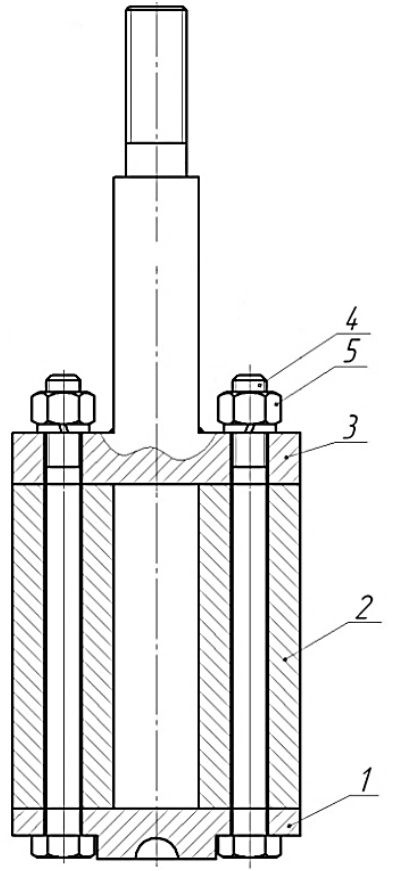

Рисунок 2 - Нагрузочная вилка

Коэффициент постели $K$ определяют по выражению:

$$
K=4 \beta^{4} E J,
$$

где $\beta$ - коэффициент, рассчитываемый по формуле $\beta=\sqrt[3]{\frac{P}{8 E J u_{0}}} ; E$ - модуль упругости материала, 
для стали $E=2,15 \times 10^{5} \mathrm{H} / \mathrm{Mм}^{2} ; P$ - нагрузка на шарик, $\mathrm{H} ; u_{0}$-деформация металлической пластины с полимерным покрытием под действием нагрузки, создаваемой шариком, мм.

Коэффициент податливости $k_{n}$ рассчитывают по зависимости

$$
k_{n}=\frac{K}{b}
$$

где $K$ - коэффициент постели упругого основания; $b$ - ширина пластины.

Для получения тарировочного графика нагрузочную вилку разбирают. Между нагрузочной пластиной 1 и пластиной 3 установлены втулки 2 квадратного сечения, которые формируют окно прямоугольного сечения, в котором размещают наружное кольцо подшипника с полимерным покрытием. Затем нагрузочную пластину пропускают через отверстие кольца подшипника и соединяют ее с втулками 2 посредством шпилек 4 и гаек 5 (рис. 2). Кольцо подшипника с полимерным покрытием опирают на поверочную плиту. В сферическое углубление нагрузочной пластины устанавливают шарик, который контактирует с копировальной бумагой, уложенной на беговую дорожку наружного кольца подшипника. Нагрузку на подшипник регистрируют манометром. После снятия нагрузки микроскопом МПБ-2 измеряют полуоси эллипса пятна контакта. В завершении строят график зависимости площади пятна контакта от нагрузки на шарик.

При исследовании распределения нагрузки и контактных напряжений между телами качения при радиальном нагружении подшипника с полимерным покрытием используют стенд (рисунок 1). Перед экспериментом из сепаратора испытываемого подшипника удаляют три шарика, которые в не нагруженной зоне. На поверхность беговой дорожки напротив центрального, первых и вторых боковых тел качения укладывают полоску копировальной бумаги. Радиальным узлом нагружения создают нагрузку на испытываемый подшипник, которую выдерживают в течение 0,25 ч. Затем нагрузку снимают и микроскопом МПБ-2 измеряют полуоси эллипса пятна контакта. Используя тарировочный график, определяют нагрузку на тела качения.

Контактные напряжения рассчитывают по известной формуле

$$
\sigma=\frac{P}{S}
$$

где $S$ - площадь пятна контакта.

На рисунке 3 показано изменение коэффициента Кирхгофа $\eta$ при различной толщине $h$ полимерного покрытия из нанокомпозита эластомера Ф-40.

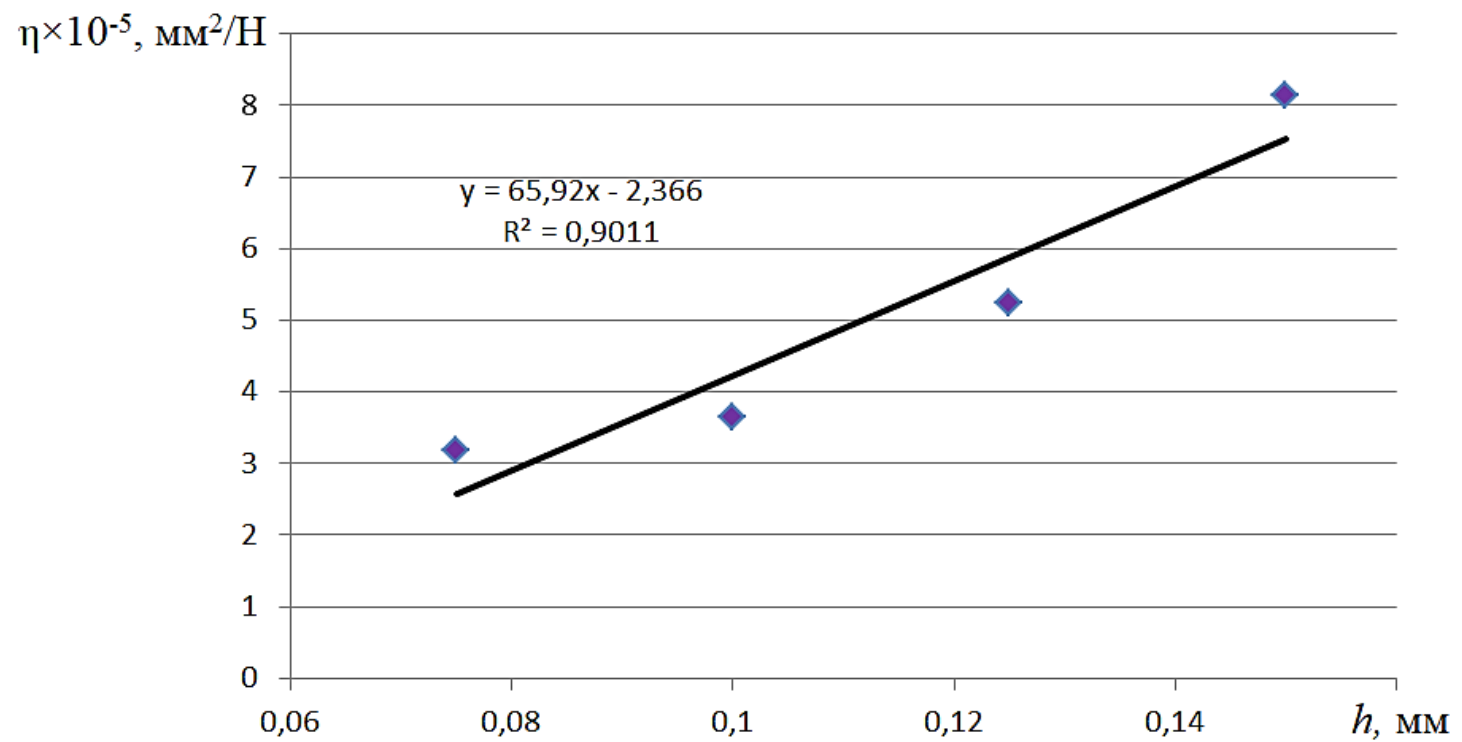

Рисунок 3 - Изменение коэффициента Кирхгофа $\eta$ при различной толщине $h$ полимерного покрытия из нанокомпозита эластомера Ф-40 
Параметр п увеличивается с ростом толщины полимерного покрытия $\mathrm{h}$. Зависимость линейная. Параметр $\eta$ имеет минимальное значение $\eta=3,18 \times 10^{-5} \mathrm{Mm}^{2} / \mathrm{H}$ на самом тонком покрытии $h=0,075$ мм. Однако в сравнении с парой сталь-сталь $\left(0,85 \times 10^{-5} \mathrm{Mм}^{2} / \mathrm{H}\right)$ этот параметр в 3,74 раза больше.

С ростом толщины полимерного покрытия $h=0,10 ; 0,125$ и 0,15 мм параметр $\eta$ увеличивается до значений 3,$64 ; 5,24$ и $8,14 \times 10^{-5} \mathrm{Mm}^{2} / \mathrm{H}$. В сравнении с парой сталь-сталь параметр $\eta$ больше в 4,$28 ; 6,16$ и 9,58 раза.

На рисунке 4 показано изменение коэффициента податливости $k_{n}$ при различной толщине $h$ полимерной подложки из нанокомпозита.

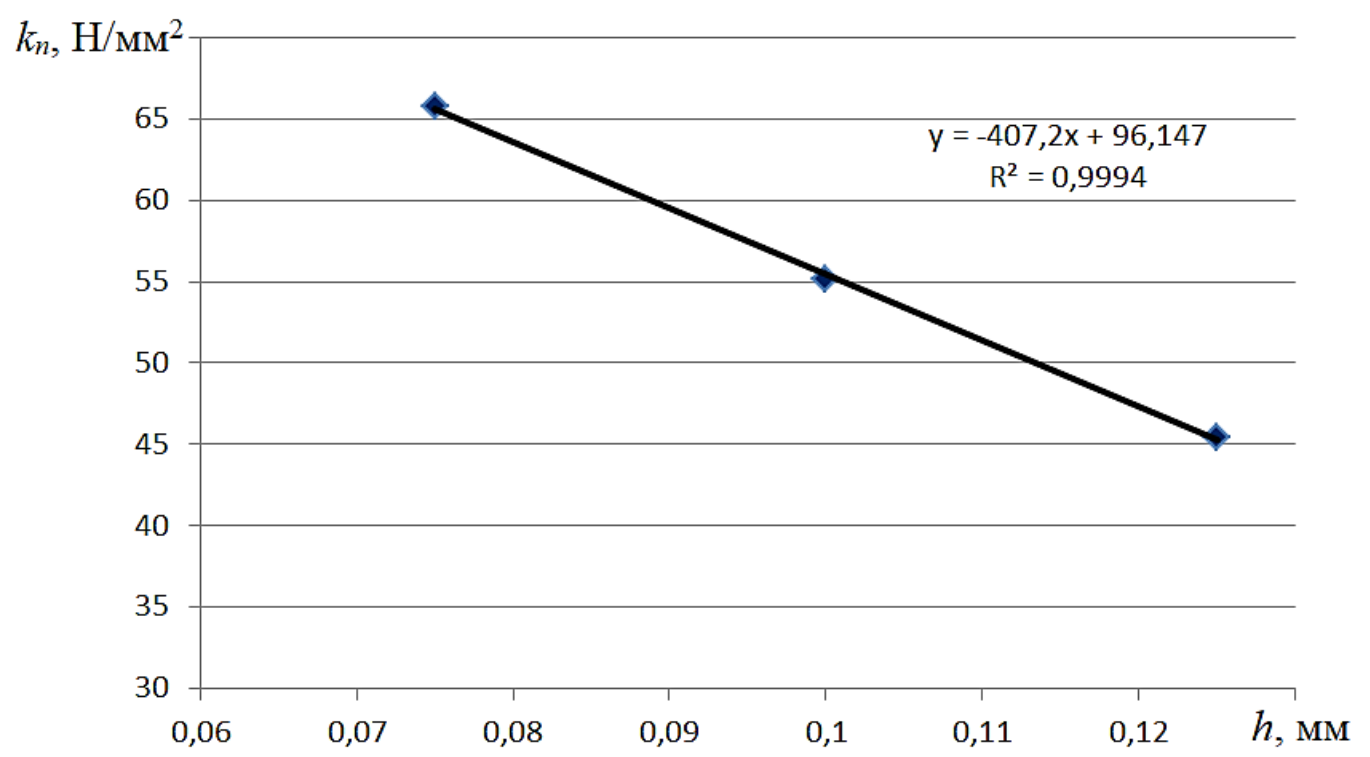

Рисунок 4 - Изменение коэффициента податливости $k_{n}$ при различной толщине $h$ полимерной подложки из нанокомпозита Ф-40

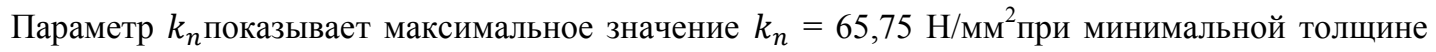
полимерного покрытия $h=0,075$ мм. Таким образом, чтобы деформировать пластину с полимерным покрытием толщиной $h=0,075$ мм на единицу длины требуется приложить максимальную силу. При большей толщине полимерного покрытияһ $=0,1$ мм параметр $k_{n}$

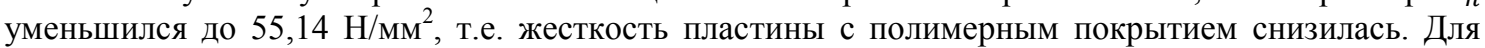
пластины с максимальной толщиной полимерного покрытия $h=0,125$ мм параметр $k_{n}$ имеет минимальное значение $k_{n}=45,39 \mathrm{H} / \mathrm{mm}^{2}$, поэтому жесткость такой пластины с полимерным покрытием наименьшая.

Зависимость $k_{n}=f(h)$ линейная. По сравнению с ненаполненным эластомером Ф-40 коэффициент податливости упругого основания в нанокомпозите увеличился от 1,29 (35,18 и 45,39

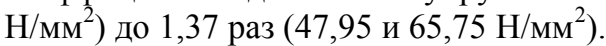

Каким образом радиальная нагрузка распределяется между телами качения в стандартном подшипнике 205 и подшипнике 205 с посадкой из нанокомпозита Ф-40 показано на рисунке 5. Зависимости 1, 2, 3 получены расчетным путем по методике [5] для подшипника 205 с нормальным радиальным и нулевым зазорами посадки.

Зависимости 1', 2' и 3'получены экспериментальным путем. Благодаря полимерному покрытию при радиальной нагрузке $P=3479$ Н нагруженность центрального тела в подшипнике с покрытием Ф-40 уменьшилась на $18 \%$.

При радиальной нагрузке $P=10437 \mathrm{H}$ снижение нагрузки на центральное тело качения составляет 17 \%. При этом увеличивается нагруженность первых боковых тел качения. В случае с радиальной нагрузкой при $P=3479$ Н в подшипнике с покрытием нанокомпозита на $12 \%$. При большей нагрузке $P=10437$ Н нагруженность первых боковых тел качения возрастает до $11 \%$. 


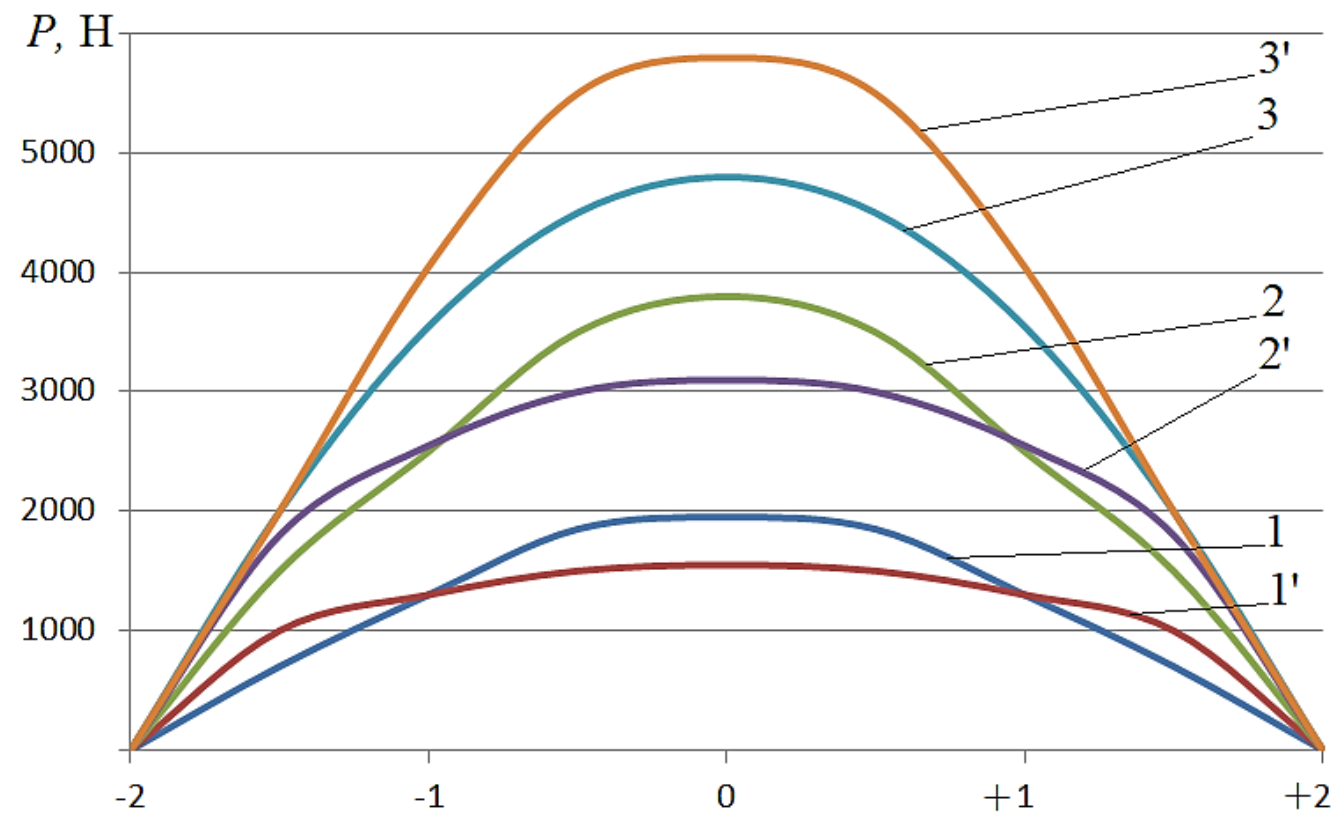

Рисунок 5 - Нагруженность тел качения в стандартном подшипнике 205 и в подшипнике 205 с посадкой, восстановленной нанокомпозитом $Ф-40: 0 ; \pm 1 ; \pm 2$ - центральное, первые и вторые боковые тела качения; 1, 2, 3 - нагруженность тел в стандартном подшипнике под радиальной нагрузкой 3479; 6958 и 10437 Н, соответственно; 1', 2', 3' - нагруженность тел в подшипнике с полимерным покрытием

В подшипнике с полимерной посадкой имеет место увеличение угла зоны нагружения и по этой причине часть радиальной нагрузки на подшипник воспринимается вторыми боковыми телами качения. В подшипнике, нагруженном нагрузкой $P=3479$ Н, вторые боковые тела качения, в подшипнике с посадкой нанокомпозита воспринимают нагрузку в 140 Н. Увеличение нагрузки до $P=10437$ Н повышает нагруженность вышеупомянутых тел качения до $419 \mathrm{H}$.

Наличие полимерной подложки подшипника увеличивает при радиальном нагружении деформацию желоба наружного кольца.

По этой причине площадь пятна контакта тел с дорожкой качения наружного кольца в подшипнике 205 с посадкой нанокомпозита до 1,7 раз больше, в отличие от стандартного подшипника.

Повышенные значения коэффициента распределения нагрузки и площади пятна контакта значительно снижают контактные напряжения в подшипнике 205 с посадкой из нанокомпозита в 1,8 раз (рисунок 6).

Под радиальной нагрузкой $P=3479$ Н напряжение,в отличие от стандартного подшипника снизилось в зоне контакта центрального тела с желобом в подшипнике с посадкой нанокомпозита в 1,76 раза.

В случае нагружения подшипника до $P=10437 \mathrm{H}$ контактное напряжение понизилось в подшипнике с покрытием нанокомпозита в 1,73 раза.

Несмотря на увеличение нагруженности первых боковых тел, благодаря большей деформации желоба наружного кольца, произошло значительное увеличение площади пятна контакта.

В итоге, в отличие от стандартного подшипника, контактные напряжения значительно меньше. При нагрузке $P=3479$ Н напряжение в подшипнике с покрытием нанокомпозита ниже в 1,5 раза. Под радиальной нагрузкой на подшипник $\mathrm{P}=10437 \mathrm{H}$ контактные напряжения уменьшились в подшипнике с покрытием нанокомпозитав 1,49 раза.

Контактные напряжения в зоне вторых тел качения составили 518 и 582 H/мм² при нагрузках соответственно 3479 и $10437 \mathrm{H}$. 


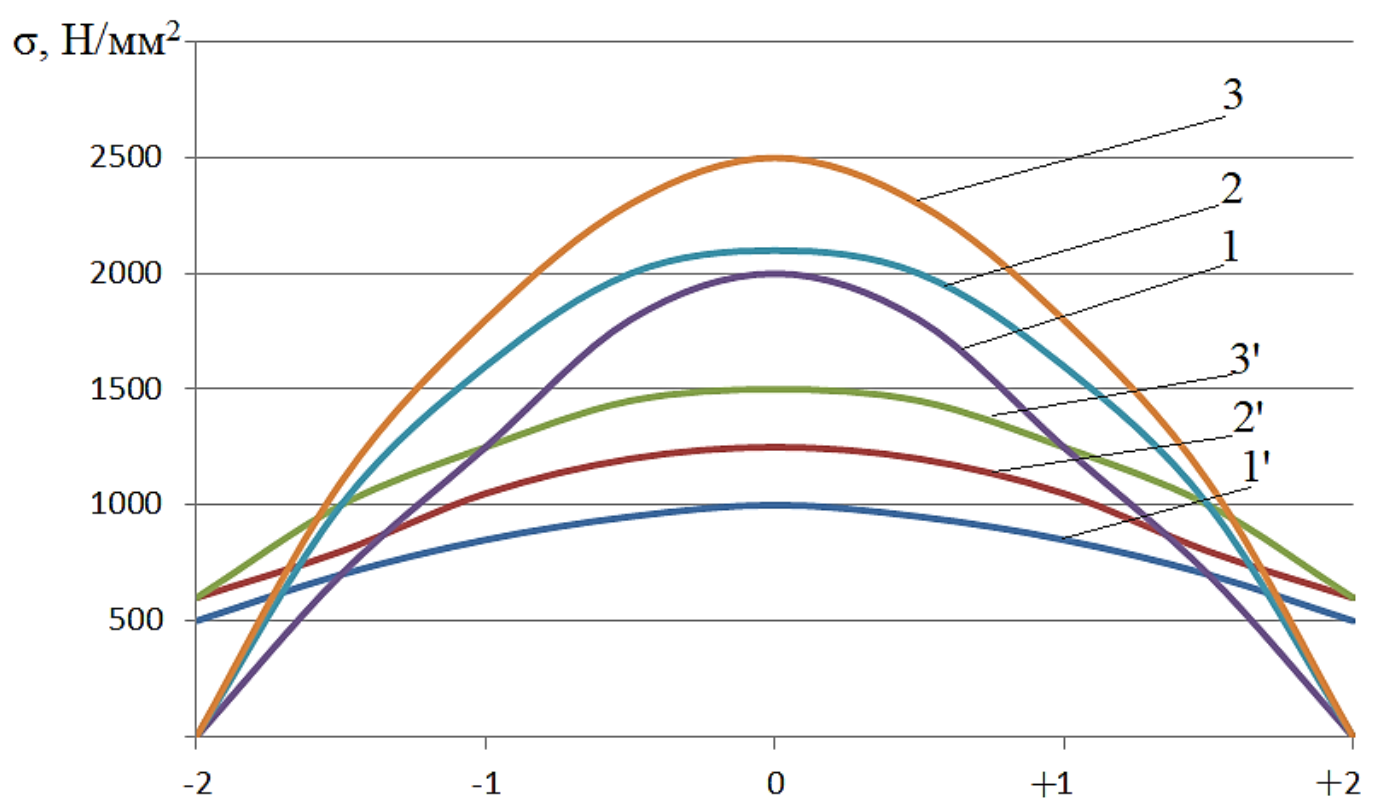

Рисунок 6 - Контактные напряжения б в стандартном подшипнике 205 и в подшипнике 205 с посадкой восстановленной нанокомпозитом Ф-40: $0 ; \pm 1 ; \pm 2$ - центральное, первые и вторые боковые тела качения; 1, 2, 3 - напряжения в стандартном подшипнике под радиальной нагрузкой $3479 ; 6958$ и $10437 \mathrm{H} ; 1^{\prime}, 2^{\prime}, 3^{\prime}$ - напряжения в подшипнике с полимерным слоем толщиной 0,15 мм при $P=3479 ; 6958$ и $10437 \mathrm{H}$

Выводы. 1. Разработана оригинальная методология исследования трибологических параметров и контактных напряжений в подшипниках качения.

2. Проведенные экспериментальные исследования показали корректность разработанной методологии и перспективность восстановления посадок подшипников полимерным нанокомпозитом на основе эластомера Ф-40, что обеспечивает снижение контактных напряжений в подшипниках и увеличивает их ресурс.

\section{Список литературы}

1. Справочник по триботехнике: В 3 т. Т. 2: Смазочные материалы, техника смазки, опоры скольжения и качения / М. Хебда, А.В. Чичинадзе. - М.: Машиностроение, 1990. - 416 с.

2. Ли Р.И. Восстановление неподвижных соединений подшипников качения сельскохозяйственной техники полимерными материалами: дис ... докт. техн. наук. - М., 2001, - 340 с.

3. Курчаткин В.В. Восстановление посадок подшипников качения сельскохозяйственной техники полимерными материалами: дис ... док. техн. наук. / В.В.Курчаткин. - М., 1989, - 407 с.

4. Ли Р.И., Псарев Д.Н., Ризаева Ю.Н., Пчельников А.В., Быконя А.Н., Мельников А.Ю. Стенд для испытания подшипников качения на долговечность [Текст]: Патент на изобретение РФ № 2719624. Заявл. 08.07.2019. // Опубл. 21.04.2020. - Бюл. №12.

5. Перель Л.Я. Подшипники качения. Расчет, проектирование и обслуживание опор: Справочник [Текст] / Л.Я.Перель.- М.: Машиностроение, 1983. - 543 с.

\section{References}

1. Spravochnik po tribotehnike: V 3 t. T. 2: Smazochnye materialy, tehnika smazki, opory skol'zhenija i kachenija / M. Hebda, A.V. Chichinadze. - M.: Mashinostroenie, 1990 - $416 \mathrm{~s}$.

2. Li R.I. Vosstanovlenie nepodvizhnyh soedinenij podshipnikov kachenija sel'skohozjajstvennoj tehniki polimernymi materialami: dis ... dokt. tehn. nauk. - M., 2001, $-340 \mathrm{~s}$.

3. Kurchatkin V.V. Vosstanovlenie posadok podshipnikov kachenija sel'skohozjajstvennoj tehniki polimernymi materialami: dis ... dok. tehn. nauk. / V.V.Kurchatkin. - M., 1989, - 407 s. 
4. Li R.I., Psarev D.N., Rizaeva Ju.N., Pchel'nikov A.V., Bykonja A.N., Mel'nikov A.Ju. Stend dlja ispytanija podshipnikov kachenija na dolgovechnost' [Tekst]: Patent na izobretenie RF № 2719624. Zajavl. 08.07.2019. // Opubl. 21.04.2020. - Bjul. №12.

5. Perel' L.Ja. Podshipniki kachenija. Raschet, proektirovanie i obsluzhivanie opor: Spravochnik [Tekst] / L.Ja.Perel'.- M.: Mashinostroenie, 1983. - 543 s.

\title{
Сведения об авторах \\ Принадлежность к организации
}

Ли Роман Иннакентьевич - доктор технических наук, профессор Федерального государственного бюджетного образовательного учреждения высшего образования «Липецкий государственный технический университет», Россия, г. Липецк, e-mail: romanlee@list.ru.

Киба Мария Романовна - аспирант Федерального государственного бюджетного образовательного учреждения высшего образования «Липецкий государственный технический университет», Россия, г. Липецк, e-mail: damsel_91@mail.ru.

Быконя Андрей Николаевич - аспирант Федерального государственного бюджетного образовательного учреждения высшего образования «Липецкий государственный технический университет», Россия, г. Липецк, e-mail: loseroff@mail.ru.

\section{Author credentials}

\section{Affiliations}

Lee Roman - Full Doctor of Technical Sciences, Professor of Federal State Budgetary Educational Institution of Higher Education "Lipetsk State Technical University", e-mail: romanlee@list.ru.

Kiba Maria - post-graduate student of Federal State Budgetary Educational Institution of Higher Education "Lipetsk State Technical University”, e-mail: damsel_91@mail.ru.

Bykonya Andrew - post-graduate student of Federal State Budgetary Educational Institution of Higher Education "Lipetsk State Technical University”, e-mail: loseroff@mail.ru.

Поступила в редакцию (Received): 23.06.2020 Принята к публикации (Accepted): 17.08.2020

УДК 621.892

DOI: $10.35887 / 2305-2538-2020-4-84-89$

\section{ТЕОРЕТИЧЕСКИЕ АСПЕКТЫ ОЦЕНКИ ЭФФЕКТИВНОСТИ ПРОМЫВКИ СИСТЕМЫ СМАЗКИ ДВС ОТ ЗАГРЯЗНЕНИЙ}

\author{
${ }^{1}$ Остриков Валерий Васильевич \\ ${ }^{2}$ Vigdorowitsch Michael \\ ${ }^{1}$ Жерновников Дмитрий Николаевич \\ ${ }^{1}$ Кочелев Александр Викторович \\ ${ }^{1}$ ФГБНУ «Всероссийский научно-исследовательский институт \\ использования техники и нефтепродуктов в сельском хозяйстве» \\ ${ }^{2}$ Angara $\mathrm{GmbH}$
}

Реферат. Работа двигателей тракторов сопряжена с высокими нагрузками $и$ значительными температурными режимами. В смазочном моторном масле и на деталях двигателя, в зависимости от наработки двигателя, накапливается значительное количество загрязнений, смол, продуктов окисления, которые осаждаются в масляных каналах системы смазки, на поршнях, под маслосъёмными кольцами. Для удаления загрязнений из системы смазки, при проведении операции технического обслуживания используются специильные промывочные масла. Одним из принятых, достаточно простых способов определения качества промывки системы смазки в двигателях тракторов является визуальный анализ изменения ивета промывочного масла от светлого жёлтого до чёрного. Детальньй анализ работ, посвящённьх оценке изменения ивета промьвочного масла в динамике отсутствует, не установлень критериальные характеристики, определяющие взаимосвязь изменения цявета масла $u$ эксплуатационные показатели двигателя. На основании результатов экспериментальных исследований по промывке системы смазки двигателей тракторов получены зависимости 
изменения иявета масла от времени промывки и средней компрессии в циилиндрах двигателя Д-240 за время работы двигателя с промывочным маслом 40 минут. По параметрическим данным получена зависимость показателя компрессии изилинропориневой группь от изменения ивета промывочного масла, имеющая характер гиперболь с вертикальной асимптотой в районе 7 единии цвета масла. В результате математического анализа получено выражение, определяющее взаимосвязь компрессии и ияета масла в процессе промывки системы смазки. Представлена дифференциильная функиия эффективности восстановления эксплуатационньх свойств двигателя.

Ключевые слова: анализ, иявет масла, компрессия, двигатель, дифференциальное уравнение, зависимость, эффективность.

\title{
THEORETICAL ASPECTS OF EVALUATING THE RINSING EFFICIENCY OF THE ICE LUBRICATION SYSTEM FROM POLLUTION
}

\author{
${ }^{1}$ Ostrikov Valery \\ ${ }^{2}$ Vigdorowitsch Michael \\ ${ }^{1}$ Zhernovnikov Dmitry \\ ${ }^{1}$ Koshelev Alexander \\ ${ }^{I}$ FSBSI “All-Russian Research Institute for Use of Machinery and Petroleum Products in Agriculture” \\ ${ }^{2}$ Angara $\mathrm{GmbH}$
}

\begin{abstract}
The operation of tractor engines is associated with high loads and significant temperature conditions. A significant amount of contaminants, resins, oxidation products that are deposited in the oil channels of the lubrication system, on the pistons, under the rings of oil scraper oils, accumulate in the lubricating engine oil and on the engine parts, depending on the engine operating time. Special flushing oils are used to remove contaminants from the lubrication system during maintenance operations. One of the accepted, quite simple methods for determining the quality of washing the lubrication system in tractor engines is a visual analysis of the color change of the washing oil from light yellow to black. There is no detailed analysis of the works devoted to the assessment of the color change of flushing oil in dynamics; criteria criteria are not established that determine the relationship between the color change of the oil and engine performance. The dependences of the color change of the oil on the flushing time and average compression in the cylinders of the D-240 engine during the operation of the engine with flushing oil for 40 minutes are obtained on the basis of experimental studies on flushing the lubrication system of tractor engines. The dependence of the compression index of the cylinder-piston group on the color change of the flushing oil, which has the character of a hyperbola with a vertical asymptote in the region of 7 units of the color of the oil, was obtained by parametric data. The expression determining the relationship between compression and oil color during the washing of the lubrication system is obtained as a result of mathematical analysis. The differential function of the efficiency of restoration of the engine operational properties is presented.
\end{abstract}

Keywords: analysis, oil color, compression, engine, differential equation, dependence, efficiency.

Введение. В процессе работы двигателей тракторов в системе смазки и на деталях цилиндропоршневой группы накапливаются загрязнения, смолисто-коксовые отложения [1, 2].

В результате образования загрязнений снижается эффективность работы двигателя и его эксплуатационные характеристики. Для удаления загрязнений из системы смазки существует достаточно много технологий [3, 4]. Одной из наиболее распространенных является промывка системы смазки специальными промывочными маслами [5, 6]. При этом очень сложно без разборки двигателя оценить эффективность процесса промывки. Достаточно простым способом оценки качества промывки двигателя является определение компрессии в цилиндрах. Изменение цвета промывочного масла от светлого до темного состояния также в определенной степени характеризует эффективность промывки.

Обсуждение результатов. Ранее проводимыми ФГБНУ ВНИИТиН исследованиями по промывке и очистке системы смазки двигателей тракторов установлена взаимосвязь и получены зависимости изменения компрессии в цилиндрах и цвета промывочного масла от времени промывки (рисунки 1, 2). 


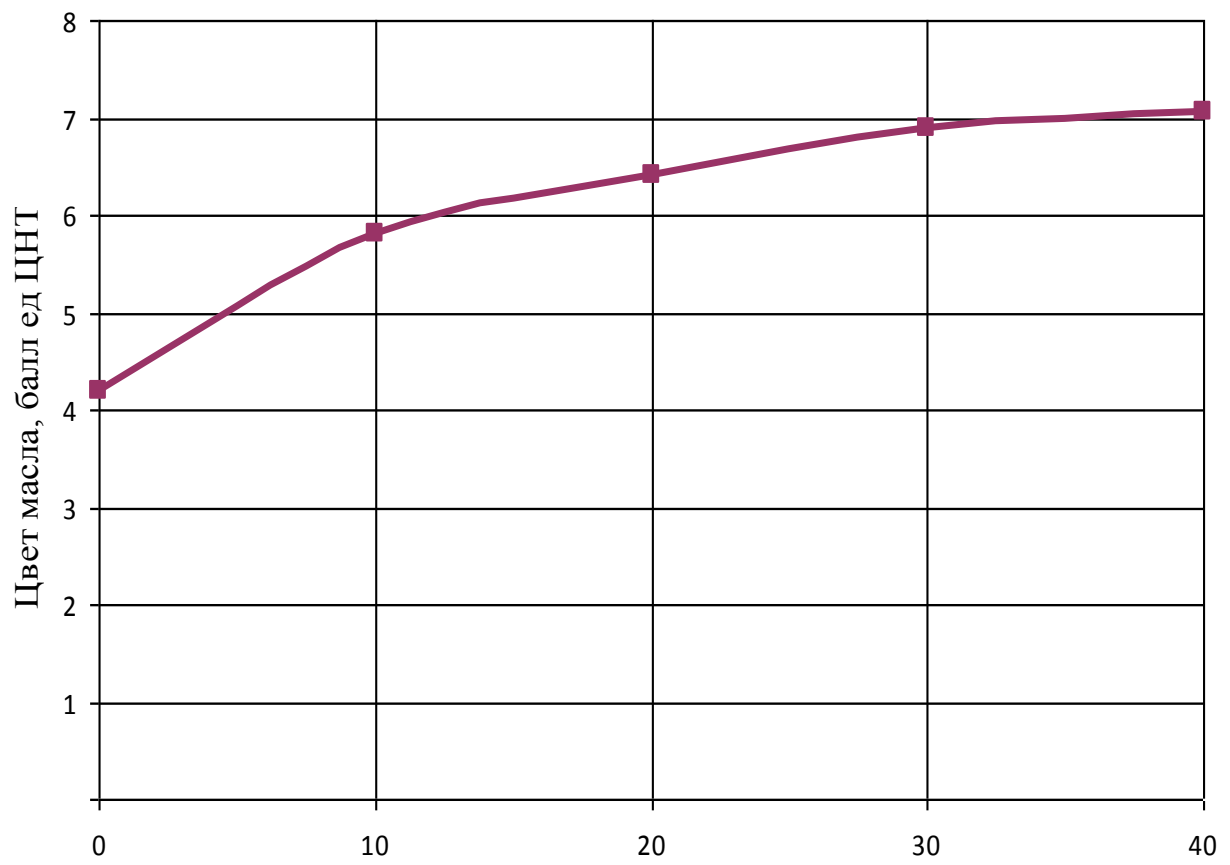

Время промывки ДВС, мин

Рисунок 1 - Параметрическая зависимость изменения цвета масла от времени промывки системы смазки двигателя Д-240

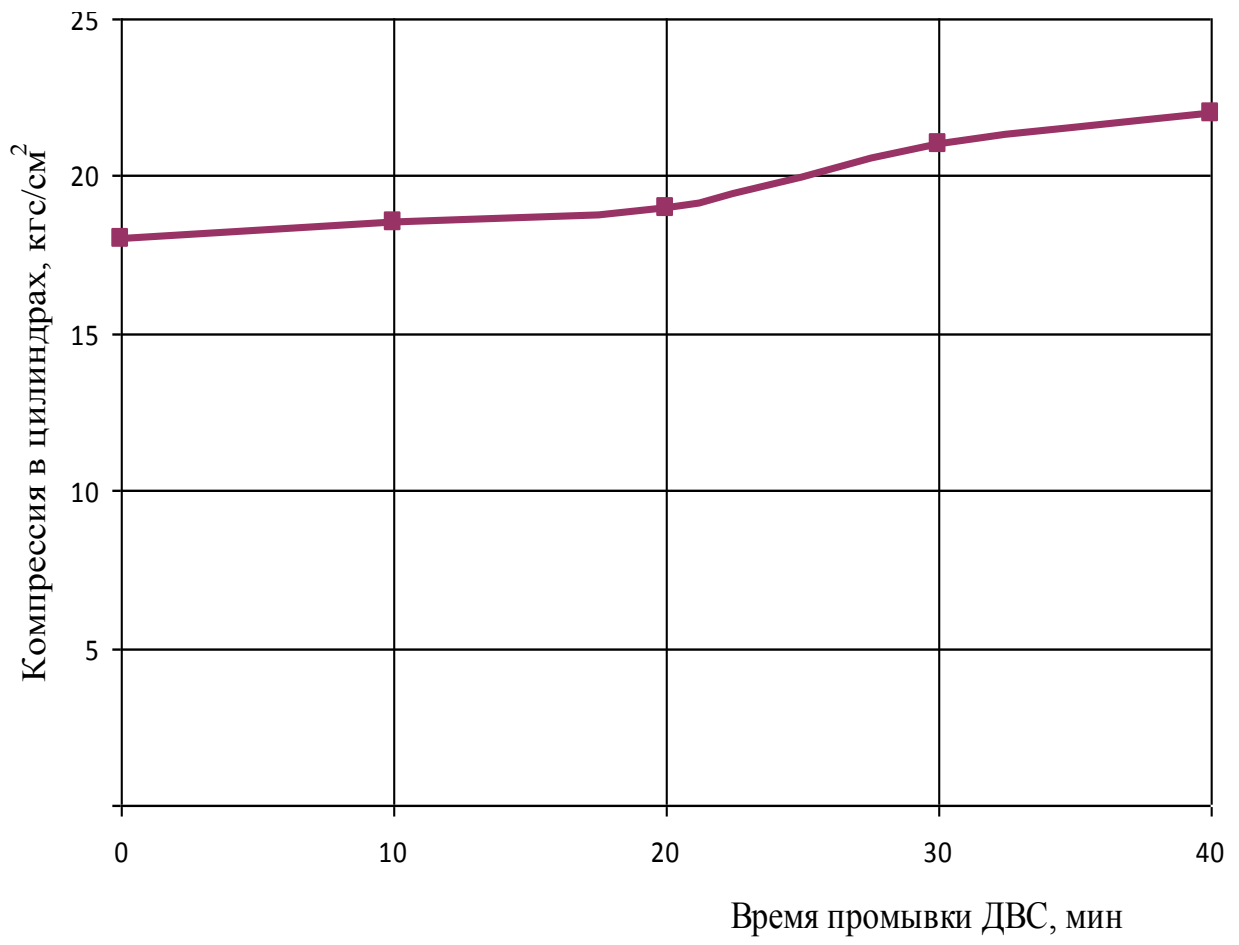

Рисунок 2 - Параметрическая зависимость изменения средней компрессии в цилиндрах от времени промывки системы смазки двигателя Д-240 
Анализируя параметрические данные компрессии и цвета промывочного масла можно построить зависимость, характеризующую их взаимосвязь (рисунок 3 ).

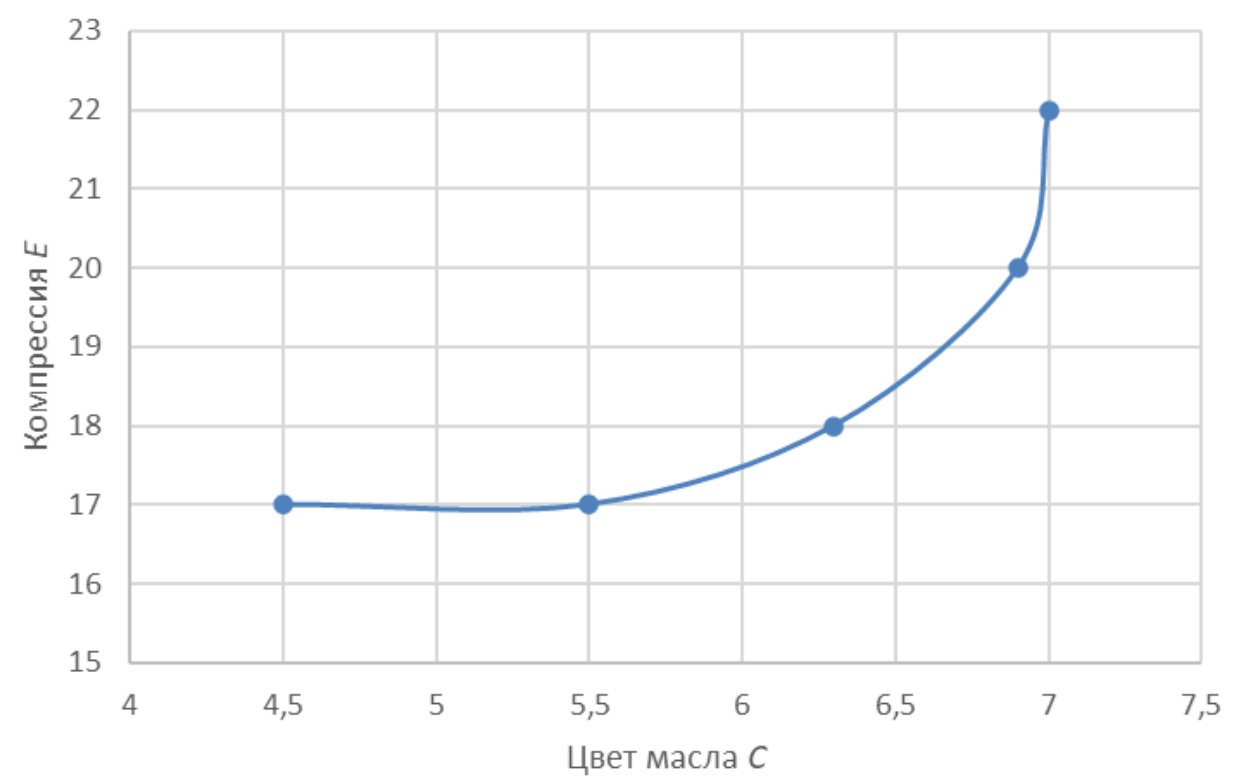

Рисунок 3 - Взаимосвязь показателей компрессии и изменения цвета промывочного масла

Зависимость имеет характер гиперболы с вертикальной асимптотой в районе 7 ед. цвета масла.

Аппроксимируем данные измерений трёхпараметрической гиперболической зависимостью вида:

$$
E=\frac{a}{C_{0}-C}+b
$$

с подлежащими определению параметрами $a, b$ и $C_{0}$. Как видно из графика, параметр $b$ ожидается порядка 17 ед., $C_{0}$ - порядка 7 ед., следовательно, параметр $a$ порядка 1 ед.

Используя метод наименьших квадратов, при этом «канонический» функционал примет вид:

$$
F=\sum_{i=1}^{N}\left[E\left(C_{i}\right)-E_{i}\right]^{2}=\sum_{i=1}^{N}\left[\frac{a}{C_{0}-C_{i}}+b-E_{i}\right]^{2},
$$

где $C_{i}, E_{i}$ - данные измерений, в нашем случае $N=4$. Приравнивая к нулю 3 частные производные:

$$
\frac{\partial F}{\partial a}=0, \frac{\partial F}{\partial C_{0}}=0, \frac{\partial F}{\partial b}=0
$$

получаем систему из 3 уравнений относительно $a, b$ и $C_{0}$. Аналитически она полностью не решается.

Тогда для $b$ можно получить выражение

$$
b=\frac{1}{N}\left[\sum E_{i}-a \sum \frac{1}{C_{0}-C_{i}}\right] .
$$

Подставляя его в 2 других, преобразуем каждое из них к виду:

$$
a=\frac{\sum \frac{E_{i}}{C_{0}-C_{i}}-\frac{1}{N} \sum E_{i} \sum \frac{1}{C_{0}-C_{i}}}{\sum \frac{1}{\left(C_{0}-C_{i}\right)^{2}}-\frac{1}{N}\left(\sum \frac{1}{C_{0}-C_{i}}\right)^{2}}
$$

U 


$$
a=\frac{\sum \frac{E_{i}}{\left(C_{0}-C_{i}\right)^{2}}-\frac{1}{N} \sum E_{i} \sum \frac{1}{\left(C_{0}-C_{i}\right)^{2}}}{\sum \frac{1}{\left(C_{0}-C_{i}\right)^{3}}-\frac{1}{N} \sum \frac{1}{\left(C_{0}-C_{i}\right)^{2}} \sum \frac{1}{C_{0}-C_{i}}}
$$

Приравнивая друг другу правые части двух последних уравнений, получаем уравнение относительно $C_{0}$, которое легко решить численно методом подбора параметра: $C_{0}=7.2$. Подставляя это значение в любое из двух последних уравнений получаем $a=1,05$. Подставляя $a$ и $C_{0}$ в приведённое выше уравнение для $b$, получим $b=16,56$.

Таким образом, наша аппроксимирующая трёхпараметрическая гиперболическая зависимость имеет вид:

$$
E=\frac{1.05}{7.2-C}+16.56
$$

Сравнительные графики имеют вид (рисунок 4)

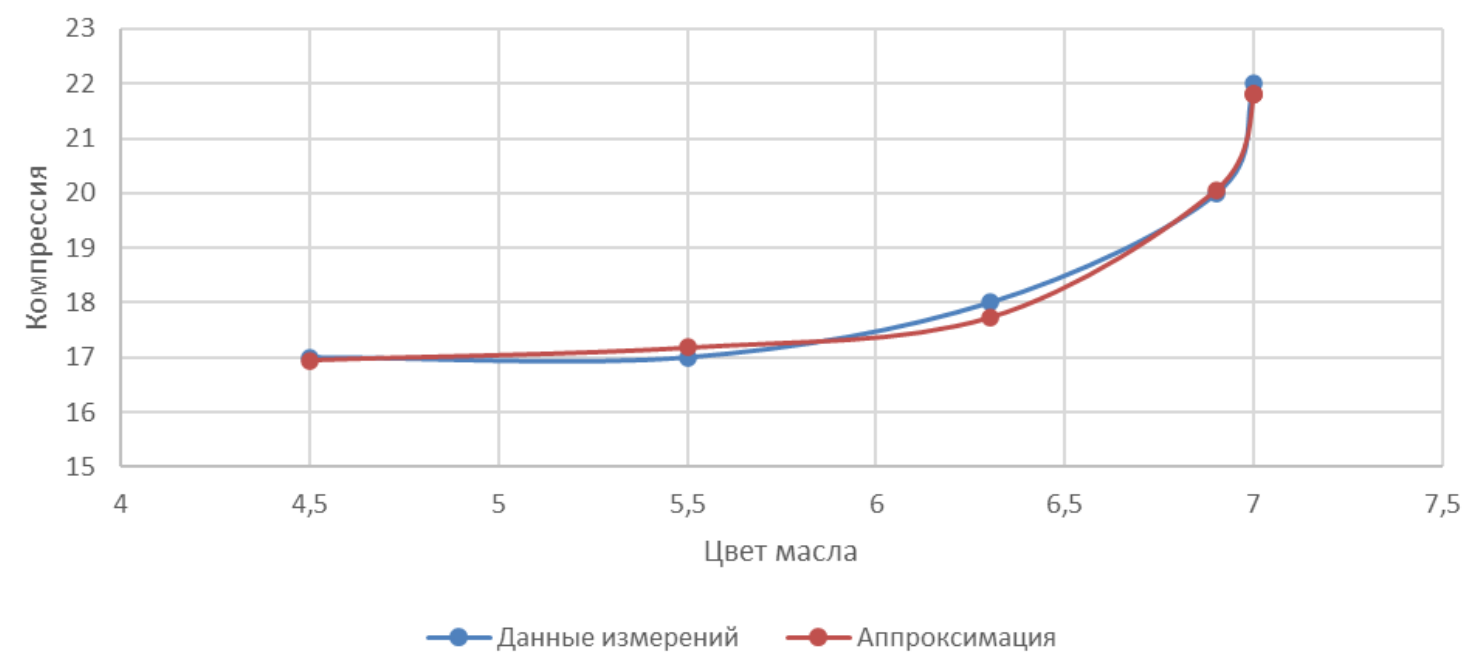

Рисунок 4 - Аппроксимирующая зависимость изменения компрессии в цилиндро-поршневой группе ДВС и цвета промывочного масла

В завершение, получим дифференциальную функцию восстановления эффективности двигателя (= очистки системы смазки):

$$
R(C)=\frac{d E}{d C}=\frac{1.05}{(7.2-C)^{2}}
$$

Определять функцию восстановления двигателя можно на другом классе функций, не только на гиперболическом. Однако подход в целом останется прежним.

Выводы. Проведённый теоретический анализ в первом приближении подтверждает гипотезу изменения цвета промывочного масла от эффективности удаления загрязнений из системы смазки двигателей машин. Установлено, что процесс промывкивзаимосвязан с изменением компрессии в цилиндропоршневой группе.

\section{Список литературы}

1. Кузьмин Н.А., Пачурин Г.В., Кузьмин А.Н. Анализ отложений в автомобильных двигателях // Современные проблемы науки и образования. - 2014. - № 1. - С. 226.

2. Behrendt C., Smith A. A Study of Diesel Fuel Injector Deposit Effects on Power and Fuel Economy Performance // 2017SAE Technical Papers. -2017. - March (March).

3. Guan Y.C., Ng G.K.L., Zheng H.Y., Hong X., Zhang Z Laser surface cleaning of carbonaceous deposits on diesel engine piston // 2013 Applied Surface Science 270. - P. 526-530 
4. Семенов В.И. Удаление загрязнений, прочно связанных с поверхностями деталей // Вестник Полоцкого государственного университета. Серия В: Промышленность. Прикладные науки - 2013. - № 11. - С. 69-72.

5. Кругов В.Ф., Остриков В.В. Промывочное масло для ДВС // Наука в центральной России 2016. - № 4 (22). - С. 35-40.

6. Кириллов В.В., Шумовский А.В., Данилов А.М. Промывочные масла для двигателей внутреннего сгорания // Мир нефтепродуктов. Вестник нефтяных компаний - 2005. - № 1. - С. 12-13.

\section{References}

1. Kuz'min N.A., Pachurin G.V., Kuz'min A.N. Analiz otlozhenij v avtomobil'nyh dvigatelyah // Sovremennye problemy nauki i obrazovaniya. - 2014. - № 1. - S. 226.

2. Behrendt C., Smith A. A Study of Diesel Fuel Injector Deposit Effects on Power and Fuel Economy Performance // 2017SAE Technical Papers. -2017. - March (March).

3. Guan Y.C., Ng G.K.L., Zheng H.Y., Hong X., Zhang Z Laser surface cleaning of carbonaceous deposits on diesel engine piston // 2013 Applied Surface Science 270. - R. 526-530

4. Semenov V.I. Udalenie zagryaznenij, prochno svyazannyh s poverhnostyami detalej // Vestnik Polockogo gosudarstvennogo universiteta. Seriya V: Promyshlennost'. Prikladnye nauki - 2013. - № 11. - S. 69-72.

5. Krugov V.F., Ostrikov V.V. Promyvochnoe maslo dlya DVS // Nauka v central'noj Rossii - 2016. - № 4 (22). - S. 35-40.

6. Kirillov V.V., SHumovskij A.V., Danilov A.M. Promyvochnye masla dlya dvigatelej vnutrennego sgoraniya // Mir nefteproduktov. Vestnik neftyanyh kompanij - 2005. - № 1. - S. 12-13.

\section{Сведения об авторах}

Принадлежность к организации

Остриков Валерий Васильевич - доктор технических наук, доцент, врио директора Федерального государственного бюджетного научного учреждения «Всероссийский научноисследовательский институт использования техники и нефтепродуктов в сельском хозяйстве», Россия, г. Тамбов, е -mail: viitinlab8@bk.ru

Вигдорович Михаил Владимирович - доктор физико-математических наук, директор Angara GmbH, Дюссельдорф, Германия, e-mail:dr.vigdorowitsch@angara-gmbh.de.

Жерновников Дмитрий Николаевич - старший лаборант-исследователь Федерального государственного бюджетного научного учреждения «Всероссийский научно-исследовательский институт использования техники и нефтепродуктов в сельском хозяйстве», Россия, г. Тамбов, е mail: viitinlab8@bk.ru.

Кошелев Александр Викторович - инженер-исследователь Федерального государственного бюджетного научного учреждения «Всероссийский научно-исследовательский институт использования техники и нефтепродуктов в сельском хозяйстве», Россия, г. Тамбов, е -mail: viitinlab8@bk.ru.

\section{Author credentials}

\section{Affiliations}

Ostrikov Valery - Full Doctor of Technical Sciences, Associate Professor, Acting Director of Federal State Budgetary Scientific Institution "All-Russian Research Institute for Use of Machinery and Petroleum Products in Agriculture”, Russia, Tambov, e-mail: viitinlab8@bk.ru.

Vigdorowitsch Michael - Full Doctor of Physical and Mathematical Sciences, Director of Angara GmbH, Dusseldorf, Germany, e-mail:dr.vigdorowitsch@angara-gmbh.de.

Zhernovnikov Dmitry - senior laboratory assistant of Federal State Budgetary Scientific Institution "All-Russian Research Institute for Use of Machinery and Petroleum Products in Agriculture”, Russia, Tambov, e-mail: viitinlab8@bk.ru.

Koshelev Alexander - Research Engineer of Federal State Budgetary Scientific Institution "AllRussian Research Institute for Use of Machinery and Petroleum Products in Agriculture”, Russia, Tambov, e-mail: viitinlab8@bk.ru. 
УДК [629.114.2+629.113].004.1

DOI: $10.35887 / 2305-2538-2020-4-90-97$

\title{
ПУТИ ЭКОНОМНОГО РАСХОДОВАНИЯ СВЕТЛЫХ НЕФТЕПРОДУКТОВ В СЕЛЬСКОМ ХОЗЯЙСТВЕ
}

\author{
${ }^{1}$ Нагорнов Станислав Александрович \\ ${ }^{1}$ Корнев Алексей Юрьевич \\ 1,2 Романцова Светлана Валерьевна \\ ${ }^{I}$ ФГБНУ «Всероссийский научно-исследовательский институт \\ использования техники и нефтепродуктов в сельском хозяйстве» \\ ${ }^{2}$ ФГБОУ ВО «Тамбовский государственный университет им. Г.Р. Державина»
}

\begin{abstract}
Реферат. Проанализировано развитие производства растениеводческой продукиии в нашей стране за 1970 - 1985 годы. Установлено, что за указанные годы фондовооруженность и энергообеспеченность сельскохозяйственного производства возросла на 350 - 400 \%. Однако обусловленного этими факторами существенного роста производительности труда и валового продукта не произошло. Выявлено, что расход дизельного топлива на один гектар посевной площади в России в 1,5 - 2,0 раза выше по сравнению с промышленно-развитыми странами. Подчеркнуто, что дальнейшее наращивание выпуска сельскохозяйственной продукции, обусловленное выполнением Стратегии развития АПК до 2030 года, приведет к еще большему увеличению потребности в энергетических ресурсах и, в частности, в дизельном топливе. Показано, что в основе инновачионного производства продукции растениеводства заложены взаимосвязанные агрономическая и инженерно-техническая системы и финансово-экономическая служба. Отмечено, что эффективность формирования индустриально-технологических методов производства продукиии растениеводства определяется, прежде всего, уровнем развития инженерно-технической системы, формирующей около $70 \%$ затрат в себестоимости сельскохозяйственной продукции. Для отечественных сельскохозяйственных предприятий до настоящего времени характерным продолжает оставаться рост материальных затрат, среди которых существенное место занимает потребление светльх нефтепродуктов. Однако неуклонный рост цен на нефтепродукты $u$ неоднократное приобретение сельскими товаропроизводителями некачественного моторного топлива неизбежно приводит $\kappa$ необходимости поиска путей рационального использования энергетических ресурсов. Поэтому всевозрастающее потребление моторного топлива сельскохозяйственным производством предусматривается, в большей мере, обеспечивать за счет его экономии. Вместе с тем, реальная возможность повымения эффективности использования моторного топлива в современных условиях зависит, прежде всего, от научной обоснованности соответствующих концепций.
\end{abstract}

Ключевые слова: моторное топливо, функциональные связи, химмотологические системы, сельскохозяйственная техника, рациональное использование энергетических ресурсов.

\section{WAYS OF ECONOMICAL CONSUMPTION OF LIGHT OIL PRODUCTS IN AGRICULTURE}

\author{
${ }^{1}$ Nagornov Stanislav \\ ${ }^{1}$ Kornev Alexey \\ ${ }^{1,2}$ Romantsova Svetlana \\ ${ }^{I}$ FSBSI "All-Russian Research Institute for Use of Machinery and Petroleum Products in Agriculture” \\ ${ }^{2}$ FSBEI HE "Tambov State University named after G.R. Derzhavin"
}

Abstract. The article analyzes the development of crop production in our country in 1970 - 1985. It is established that over these years, the stock and energy supply of agricultural production has increased by $350-400 \%$. However, due to these factors, there was no significant increase in labor productivity and gross product. It was found that the consumption of diesel fuel per hectare of acreage in Russia is 1,52,0 times higher than in industrialized countries. It was emphasized that further increase in agricultural output, due to the implementation Of the strategy for the development of the agro-industrial complex until 2030, will require an even greater increase in the demand for energy resources and, in particular, for 
diesel fuel. It is shown that the basis of innovative production of crop production is based on interconnected agronomic and engineering systems and financial and economic services. It is noted that the efficiency of forming industrial and technological methods of crop production is determined primarily by the level of development of the engineering and technical system, which forms about $70 \%$ of the costs in the cost of agricultural products. For domestic agricultural enterprises, the growth of material costs continues to be characteristic, among which a significant place is occupied by the consumption of light oil products. However, the steady increase in prices for petroleum products and the repeated purchase of low-quality motor fuel by rural producers inevitably leads to the need to find ways to rationalize the use of energy resources. Therefore, the increasing consumption of motor fuel by agricultural production is more likely to be achieved by saving it. At the same time, the real possibility of improving the efficiency of motor fuel use in modern conditions depends primarily on the scientific validity of the relevant concepts.

Keywords: Motor fuel, functional connections, chemical systems, agricultural machinery, rational use of energy resources.

Введение. На протяжении многих десятков лет проблема увеличения топливной экономичности машинно-тракторных агрегатов (МТА) неизменно остается ведущим направлением исследований как в нашей стране [1 - 10], так и за рубежом [11 - 14].

Особый интерес к этой краеугольной проблеме обусловлен не только существенным влиянием светлых нефтепродуктов на себестоимость и экономическую эффективность продукции растениеводства в целом, но и их важнейшей роли при поиске путей предупреждения изменения экологического равновесия в среде нашего обитания. Вопросы, поднятые нами в [15], нашли дальнейшее развитие в настоящей работе.

Цель исследований - с учетом функциональных связей химмотологических систем сельскохозяйственной техники выявить основные направления и способы экономии топливносмазывающих материалов (ТСМ) при производстве продукции растениеводства.

Материалы и методы. В ходе исследований использованы методы системно-структурного и функционального анализа, а также аналитические, статистические, сравнительные и информационно-логические методы обработки и анализа исходной информации, методы системного подхода.

Результаты и их обсуждение. Основными направлениями расходования моторного топлива в сельскохозяйственном производстве являются растениеводство, животноводство, автомобильный и тракторный транспорт. Прирост потребления энергоресурсов возможно обеспечить более чем на 25 \% лишь за счет их экономии. Исходя из вышесказанного [13], можно перейти к следующим основным направлениям работ по обеспечению экономного расходования и рационального (эффективного) использования топливно-смазывающих материалов (ТСМ).

Краеугольным вопросом энергосбережения является разработка систем производства продукции растениеводства, оптимальных с точки зрения энергозатрат. Среди комплекса задач указанного направления краеугольной является совершенствование технологий производства сельскохозяйственной продукции. За последние годы выявлено, что для получения максимального эффекта энергосбережения предпочтительнее внести коренные изменения в существующие технологии, такие как минимальная или нулевая обработка почвы, уборка зерновых культур, применение многоцелевых силовых и транспортных модулей и т.д.

Совершенствование таких производственных систем должно носить комплексный характер, учитывать последействия при замене операций процесса. Необходимо при оценке эффективности энергосбережения учитывать переток энергии из начальных операций на конечные и наоборот. Здесь важна суммарная оценка энергопотребления, то есть учет прямой и косвенной затрачиваемой энергии.

Повышение коэффициента использования топлива

Анализ использования автотракторного топлива в растениеводстве показывает, что как от энергоносителя отдача от дизельного топлива и автомобильного бензина не такая, которую хотелось бы иметь. Отношение энергии, содержащейся в топливе, к минимально необходимому количеству, которое требуется для совершения технологической операции, характеризует степень использования энергии топлива и одновременно технический уровень средств производства, преобразующих энергию в необходимую работу. 
Следовательно, совершенствование рабочего процесса в дизелях, снижение удельного расхода и механических потерь, уменьшение массы прицепных и навесных орудий, совершенствование рабочих органов - одно из главных направлений, реализация которого позволит добиться существенной экономии моторного топлива. Различные узлы MTA характеризуются определенными факторами, интегральное взаимодействие которых обуславливает конкретный режим эксплуатации МТА в целом. Обычно в научно-технической литературе рассматриваются по отдельности различные стороны решаемой проблемы (например, работы дизелей, тракторов или сельхозмашин). Поскольку расход топлива непосредственно связан с комплектованием и эксплуатацией МТА, то эффективность использования ТСМ обуславливается более полным использованием тягово-сцепных свойств трактора. В нашем случае наибольший интерес представляют анализ различных факторов, обуславливающих рациональное использование ТСМ, которое невозможно осуществить без рекомендаций, полученных вследствие интеграции усилий разработчиков сельхозтехники и товаропроизводителей, эксплуатирующих эту технику. Наиболее удобной формой является комплексное рассмотрение функциональных связей химмотологических систем сельскохозяйственной техники, представленное на рисунке 1.

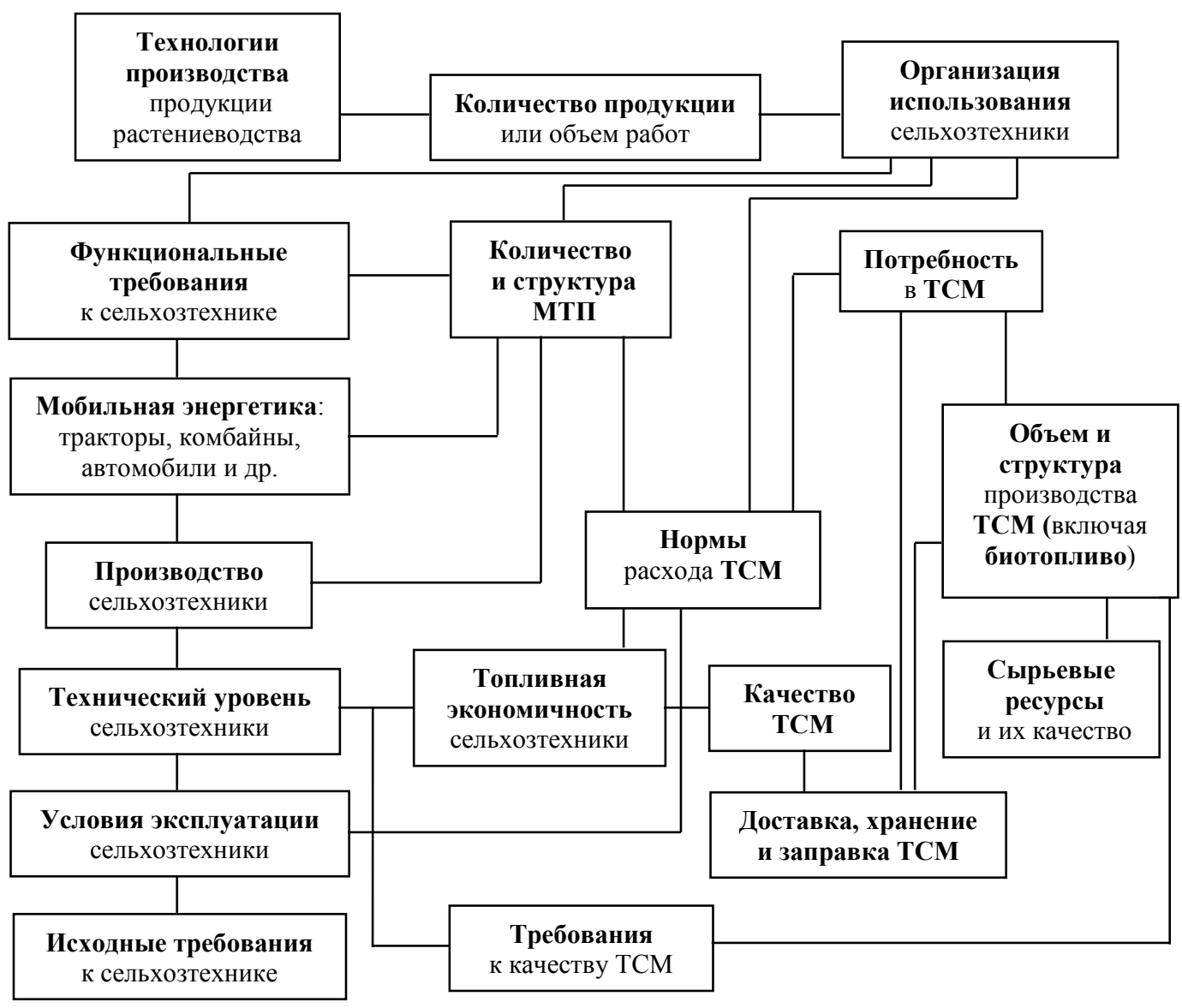

Рисунок 1 - Функциональные связи химмотологических систем сельскохозяйственной техники

Вторым комплексом задач этого направления является оптимизация процессов использования машин, рациональный учет влияния параметров среды на тяговые свойства, структура машиннотракторного парка, обеспечивающая оптимальные тяговые характеристики, развитие сервисной службы, обеспечивающей характеристики эксплуатируемых машин на уровне новой техники.

Повышение урожайности в растениеводстве

Увеличение урожайности позволит снизить энергозатраты на единицу продукции, поэтому внедрение новых культур и сортов, приемов обработки и борьбы с вредителями растений, учет 
факторов внешней среды при размещении культур в различных зонах страны или оптимизация севооборотов, селекция - это тот круг задач, решение которых позволит снизить энергоемкость продукции.

Осуществление замены нефтепродуктов на другие источники энергии.

В силу своего развития, состава и условий окружающей среды, производственные системы испытывают дефицит в том или ином источнике энергии. Поэтому в зависимости от поставленных задач, не экономии вообще энергии, что тоже необходимо, а с целью снижения расхода какоголибо одного энергоносителя осуществляется его замена на менее дефицитный для данной производственной системы вид энергии. В нашем случае моторное топливо выступает в качестве дефицита практически во всех регионах страны. Поэтому должны решаться задачи по обоснованию экономически и социально выгодной замене его на возобновляемые источники энергии.

Создание экологически чистых производственных систем.

Вопросы экологии при производстве сельскохозяйственной продукции непосредственно связаны с общегосударственной политикой в области защиты окружающей среды от деятельности человека. Это комплекс вопросов, связанных с технологией обработки почв, мелиорацией, применением удобрений и средств борьбы с вредителями и болезнями растений. Решение этих вопросов также должно осуществляться с минимально необходимыми энергозатратами.

Совершенствование службы обеспечения ТСМ агропромышленных предприятий

Разработка и выполнения комплекса задач по борьбе с потерями ТСМ в процессе их транспортирования, хранения и выдачи, решаемых путем совершенствования техникотехнологического уровня средств труда, позволит перевести службу на более высокий уровень.

Таким образом, краткие характеристики и содержание изложенных направлений экономного расходования ТСМ в аграрном секторе страны позволяют наметить основные долговременные цели, обуславливающие экономное расходование ТСМ:

1) разработка систем производства продукции, оптимальных с точки зрения энергозатрат;

2) повышение коэффициента использования моторного топлива;

3) повышение урожайности в растениеводстве;

4) осуществление замены нефтепродуктов на другие источники энергии и применение возобновляемых энергоресурсов;

5) создание экологически чистых производственных систем;

6) совершенствование службы обеспечения ТСМ агропромышленных предприятий;

7) разработка баланса потребности хозяйства в энергоносителях.

Указанные цели являются долговременными, рассчитанными на длительную перспективу и являются основными направлениями деятельности всех звеньев управления АПК страны. Опыт работы по совершенствованию использования ТСМ, их рациональному использованию показывает, что без надлежащей заинтересованности потребителей экономно расходовать ТСМ, не достигается нужного эффекта.

Важность комплексного подхода к вопросам экономного расходования ТСМ подчеркивается такими обстоятельствами, когда замена, например, дизельного топлива на возобновляемые источники энергии, тормозится отсутствием нужного оборудования и соответствующих рекомендаций по использованию альтернативных видов топлива в мобильной энергетике для различных регионов нашей страны.

Незначительное применение энергосберегающих технологий и низкая отдача от интенсивных технологий обусловлена недостаточным качеством проведения полевых работ, нарушением сроков проведения агромероприятий. Сегодня положение на рынке сельхозпродукции диктует необходимость определения таких путей решения поставленных целей, которые бы позволили осуществить комплексный подход с учетом применяемых механизмов хозяйствования к вопросам экономии ТСМ. В отличие от целей, пути их решения не должны носить долговременный характер. Поставленная задача столь сложна и многообразна, что необходима определенная последовательность, этапность ее решения. В этом случае на каждом этапе могут быть свои пути, возможна их корректировка. Важно только избрать эти пути такими, которые позволят решить задачу комплексно, используя системный подход. В этом случае возможна высокая эффективность всей работы. 
Рассмотрим основные пути достижения поставленной цели.

Разработка систем производства продукции, оптимальных с точки зрения энергозатрат.

Завершение комплексной механизации и автоматизации процессов сельскохозяйственного производства, внедрение интенсивных технологий вызывает повышенный расход энергоресурсов и, в частности, дизельного топлива. На увеличение валового сбора продукции можно рассчитывать в результате выявления и рационального использования возможностей данной производственной системы, соблюдения всех требований технологий. В этом случае основными направлениями достижения поставленной цели будут оптимальная механизация процессов производства, рациональная эксплуатация машинно-тракторного парка, рациональное сочетание операций по уходу, выращиванию, уборке, складированию, консервации и переработке продукции. Здесь имеется в виду оптимальность с точки зрения энергозатрат и не в ущерб основному предназначению.

Увеличение в последнее время использование колесных тракторов большой мощности привело к тому, что возросли потери топлива из-за невозможности полной загрузки их мощности, повышенной величины буксования. Следовательно, необходимо рациональное сочетание гусеничных и колесных машин в хозяйстве. Кроме этого необходимо решить вопрос, когда выгодно или необходимо за счет экономии топлива потерять в производительности и наоборот.

Анализ использования тракторов в хозяйстве показывает, что почти $45-60$ \% своей загрузки в течение года они используются на транспортных работах. В этом случае тяговое усилие на крюке составляет 40 - 50 \% от номинального, следовательно, рационализация схем грузоперевозок, увеличение числа автомобилей, занятых на перевозках, позволит высвободить определенный процент автотракторного топлива.

Энергосберегающая технология, являясь частью производственной системы получения продукции, дает эффект экономии топлива лишь в том случае, когда качественно и в срок выполняются все необходимые операции.

Повышение коэффиичента использования ТСМ.

Характеризуя степень использования энергии, содержащейся в топливе, данный коэффициент позволяет проводить целенаправленную работу по совершенствованию составляющих всего технологического процесса или отдельных операций. Следовательно, оптимизация удельного расхода топлива, повышение КПД трансмиссий, снижение расхода мощности на привод вспомогательных органов мобильной машины - это пути повышения коэффициента использования топлива и снижения энергозатрат на производство продукции.

Анализ производства продукции растениеводства в зарубежных странах показывает, что отечественная сельскохозяйственная техники располагает большими резервами в этом направлении. Аналогичные требования необходимо предъявить к сервисным службам АПК, обеспечивающих техническое обслуживание и ремонт сельхозтехники. Удельный расход топлива тракторами после ремонта значительно выше, чем у новых. Нарушение проектной геометрии сельскохозяйственных машин после их эксплуатации помимо некачественной работы приводит к перерасходу топлива. Таким образом, повышение качества ремонта и технического обслуживания является одним из важнейших путей снижения затрат энергии на производство сельхозпродукции.

Повышение урожайности в растениеводстве.

Снижение удельного расхода топлива, то есть на единицу продукции, можно достичь путем повышения урожайности. Используя достижения селекции, а также современные методы хозяйствования можно существенно повысить валовой сбор продукции и соответственно снизить удельные затраты энергоресурсов.

Осуществление замены нефтепродуктов на альтернативные источники энергии.

Пути решения поставленных целей этого направления пока наиболее материалоемкие и требуют дополнительных затрат денежных средств на развертывание производства и проведение научных разработок.

Использование альтернативных источников энергии требует соответствующей подготовки и переподготовки кадров, призванных обслуживать данные установки в АПК.

Создание экологически чистых производственных систем.

Создание производственных систем, обладающих наивысшей эффективностью по производству продукции и энергосбережению неразрывно связано с вопросами экологии. Если 
уменьшать долю прямых энергозатрат в производственной системе, то будут возрастать косвенные затраты, связанные с применением удобрений, средств защиты растений. Концентрация производства, снижающая стоимость и энергозатраты на единицу продукции, выдвигает вопросы утилизации отходов, которые легко решались на мелких объектах. Поэтому, для достижения экономии энергоресурсов, необходимо идти по пути создания рациональной, с точки зрения экологии, структуры энергозатрат в производственной системе, добиваясь оптимального сочетания энергосбережения и экологической чистоты.

Совершенствование службы обеспечения ТСМ агропромышленных предприятий.

Основными путями достижения поставленной цели являются совершенствование технологии обеспечения ТСМ, техническое перевооружение службы, введение автоматических систем контроля и учета количества ТСМ. Весь этот комплекс вопросов позволит снизить потери ТСМ в процессе транспортирования, хранения и выдачи на $1,5-2,0 \%$ от их годового расхода по хозяйству.

Разработка баланса потребности хозяйства в энергоресурсах.

Агропромышленное производство потребляет практически все виды энергоресурсов (электрическую энергию, природный и сжиженный газ, мазут, автотракторное топливо, твердые виды топлива и др.). Производственные системы функционируют в различных почвенноклиматических регионах, обладающих различным набором экономически выгодных энергоресурсов. Поэтому каждое агропромышленное предприятие должно применять для функционирования своих производственных систем те виды энергоносителей, которые экономически выгодно применять в зоне действия системы. Следовательно, нужны пути решения этих задач. Производитель продукции должен иметь перечень экономически выгодных для данного региона энергоресурсов и возможность беспрепятственного удовлетворения своей потребности, т.е. потребность хозяйства в видах энергоресурсов будет сбалансирована.

Рассмотрим средства достижения поставленных целей.

Решение поставленных целей возможно только лишь с использованием намеченных путей и соответствующих средств. Необходимые средства могут быть техническими, финансовыми, организационными. При реализации целей выбранными средствами должно быть обеспечено единство организационных средств с остальными. В противном случае будет нарушен комплексный подход, и эффективность решения будет низкая или вообще невозможна. Как правило, при решении задач экономии ТСМ возможны несколько альтернативных подходов.

В одном случае имеются финансовые и технические средства и необходимо получить экономию ТСМ в определенный промежуток времени. В другом случае необходимо сэкономить ТСМ, имея ограниченные ресурсы по финансам и техническим средствам. Кроме этого, спецификой агропромышленных предприятий является то обстоятельство, что практически все технические средства, особенно новейшие, внутри отрасли не производятся. Следовательно, возрастает роль организационных средств, призванных объединять и координировать разработку необходимых технических средств. Зависимость потребителей ТСМ, которым экономически выгодно бороться за их рациональное использование, от производителей соответствующих технических средств значительно усложняет реализацию намеченных целей, но не превращает ее в нерешаемую проблему.

Заключение. Сформулированные выше стратегические цели по снижению расхода ТСМ в АПК приводят к необходимости поднять качество управления научно-техническим прогрессом, достижения которого будут способствовать снижению расхода топлива. Положенный в их основу целевой принцип и охват ими всего круга задач, позволит управлять всем процессом НТП экономическими методами, в частности, определить приоритетность в решении тех или иных целей, наметить конкретные, взаимоувязанные этапы решения нескольких целей одновременно.

\section{Список литературы}

1. Клейменов, О.А. О повышении эффективности использования нефтепродуктов в АПК / О.А. Клейменов, В.В. Остриков, С.А. Нагорнов // Вестник РАСХН. - 2001. - № 4. - С. 16-17.

2. Зазуля, А.Н. Проблемы эффективного использования нефтепродуктов и методы их решения / А.Н. Зазуля, В.В. Остриков, С.А. Нагорнов // Совершенствование технологии и технических средств механизации сельского хозяйства: Сб. науч. тр. / Пензенская ГСХА. - Пенза: РИО ПГСХА, 2001. - С. 36-41. 
3. Нагорнов, С.А. Эффективное использование нефтепродуктов в сельском хозяйстве / С.А. Нагорнов, С.В. Романцова, А.Н. Зазуля, И.Г. Голубев. - М.: ФГНУ «Росинформагротех», 2006. - 192 с.

4. Остриков, В.В. Концептуальные предпосылки повышения эффективности использования нефтепродуктов в АПК / В.В. Остриков, С.А. Нагорнов // Техника в сельском хозяйстве. - 2002. № 4. - С. 24-27.

5. Толчеев, Г.Г. Методические подходы к прогнозированию потребления нефтепродуктов в АПК / Г.Г. Толчеев, О.А. Клейменов, С.А. Нагорнов // Вестник РАСХН. - 2000. - № 1. - С. 71-74.

6. Кутьков, Г.М. Развитие технической концепции трактора / Г.М. Кутьков // Тракторы и сельхозмашины. - 2019. - № 1. - С. 27-35.

7. Хабардин, В.Н. Особенности использования машин в сельском хозяйстве как факторы развития их технического обслуживания / В.Н. Хабардин, Н.В. Степанов, М.В. Чубарева // Вестник Иркутской ГСХА. - 2009. - № 36. - С. 129-137.

8. Арженовский, А.Г. Методы определения энергетических и топливно-экономических показателей машинно-тракторных агрегатов / А.Г. Арженовский // Сельскохозяйственные машины и технологии. - 2017. - № 6. - С. 36-40.

9. Погорелый, Л.В. Сельскохозяйственная техника и технологии будущего / Л.В. Погорелый. Киев: Урожай, 1988. - 176 с.

10. Старцев, А.В. Эффективность использования машинно-тракторных агрегатов с двигателями, работающими на многокомпонентном топливе. Сообщение 1. Экономическая оценка / А.В. Старцев, И.И. Сторожев // «Наука и производство»: Сб. науч. труд. / Под ред. В.В. Ерофеева. - Челябинск: ЧРО РАЕН, 2009. - С. 10 - 17.

11. Alene, A.D. Technology adoption and farmer efficiency in multiple crops production in eastern Ethiopia: a comparison of parametric and non-parametric dis-tance functions / A.D. Alene, M. Zeller // Agricultural economics review, 2005, Vol. 6, № 1, pp. 5-17. Режим доступа: http://ageconsearch.umn.edu/handle/44089, свободный.

12. Arnade, C. Estimating a profit function in the presence of inefficiency: an application to Russian agriculture / C. Arnade, M.A. Trueblood // Journal of Agricultural and Resource economics. - 2002. - № 27(1): 94-113 - Режим досту-па: https://ideas.repec.org/a/ags/jlaare/31089.html, свободный.

13. Brummer, B. Productivity and efficiency in Chinese agriculture: a dis-tance function approach / B. Brummer, T. Glauben, W. Lu // 25th IAAE, Durban, South Africa, 2003. - P 941 - 955., - Режим доступа: http://ecsocman.hse.ru/data/ 323/658/1219/074.pdf, свободный.

14. Chetroiu, R. The concept of economic efficiency in agriculture / R. Chetroiu, I. Calin // Munich Personal RePEc Archive paper \# 55007, 2013, posted 3. http://mpra.ub.uni-muenchen.de/55007/

15. Нагорнов, С.А. Пути повышения эффективности использования светлых нефтепродуктов в сельском хозяйстве /С.А. Нагорнов, А.Ю. Корнев, С.В. Романцова // Наука в центральной России. - 2020. - № 3(45). - C. 112-121.

\section{References}

1. Klejmenov, O.A. O povyshenii effektivnosti ispol'zovaniya nefteproduktov $\mathrm{v}$ APK / O.A. Klejmenov, V.V. Ostrikov, S.A. Nagornov // Vestnik RASKHN. - 2001. - № 4. - S. 16-17.

2. Zazulya, A.N. Problemy effektivnogo ispol'zovaniya nefteproduktov i metody ih resheniya / A.N. Zazulya, V.V. Ostrikov, S.A. Nagornov // Sovershenstvovanie tekhnologii i tekhnicheskih sredstv mekhanizacii sel'skogo hozyajstva: Sb. nauch. tr. / Penzenskaya GSKHA. - Penza: RIO PGSKHA, 2001. - S. 36-41.

3. Nagornov, S.A. Effektivnoe ispol'zovanie nefteproduktov v sel'skom hozyajstve / S.A. Nagornov, S.V. Romancova, A.N. Zazulya, I.G. Golubev. - M.: FGNU «Rosinformagrotekh», 2006. - 192 s.

4. Ostrikov, V.V. Konceptual'nye predposylki povysheniya effektivnosti ispol'zovaniya nefteproduktov v APK / V.V. Ostrikov, S.A. Nagornov // Tekhnika v sel'skom hozyajstve. - 2002 . - № 4. - S. 24-27.

5. Tolcheev, G.G. Metodicheskie podhody k prognozirovaniyu potrebleniya nefteproduktov v APK / G.G. Tolcheev, O.A. Klejmenov, S.A. Nagornov // Vestnik RASKHN. - 2000. - № 1. - S. 71-74.

6. Kut'kov, G.M. Razvitie tekhnicheskoj koncepcii traktora / G.M. Kut'kov // Traktory i sel'hozmashiny. - 2019. - № 1. - S. 27-35. 
7. Habardin, V.N. Osobennosti ispol'zovaniya mashin v sel'skom hozyajstve kak faktory razvitiya ih tekhnicheskogo obsluzhivaniya / V.N. Habardin, N.V. Stepanov, M.V. CHubareva // Vestnik Irkutskoj GSKHA. - 2009. - № 36. - S. 129-137.

8. Arzhenovskij, A.G. Metody opredeleniya energeticheskih i toplivno-ekonomicheskih pokazatelej mashinno-traktornyh agregatov / A.G. Arzhenovskij // Sel'skohozyajstvennye mashiny i tekhnologii. 2017. - № 6. - S. 36-40.

9. Pogorelyj, L.V. Sel'skohozyajstvennaya tekhnika i tekhnologii budushchego / L.V. Pogorelyj. Kiev: Urozhaj, 1988. - 176 s.

10. Starcev, A.V. Effektivnost' ispol'zovaniya mashinno-traktornyh agregatov $\mathrm{s}$ dvigatelyami, rabotayushchimi na mnogokomponentnom toplive. Soobshchenie 1. Ekonomicheskaya ocenka / A.V. Starcev, I.I. Storozhev // «Nauka i proizvodstvo»: Sb. nauch. trud. / Pod red. V.V. Erofeeva. CHelyabinsk: CHRO RAEN, 2009. - S. 10-17.

11. Alene, A.D. Technology adoption and farmer efficiency in multiple crops production in eastern Ethiopia: a comparison of parametric and non-parametric dis-tance functions / A.D. Alene, M. Zeller // Agricultural economics review, 2005, Vol. 6, № 1, pp. 5-17. Режим доступа: http://ageconsearch.umn.edu/handle/44089, свободный.

12. Arnade, C. Estimating a profit function in the presence of inefficiency: an application to Russian agriculture / C. Arnade, M.A. Trueblood // Journal of Agricultural and Resource economics. - 2002. - № 27(1): 94-113 - Режим досту-па: https://ideas.repec.org/a/ags/jlaare/31089.html, свободный.

13. Brummer, B. Productivity and efficiency in Chinese agriculture: a dis-tance function approach / B. Brummer, T. Glauben, W. Lu // 25th IAAE, Durban, South Africa, 2003. - Р 941 - 955., - Режим доступа: http://ecsocman.hse.ru/data/ 323/658/1219/074.pdf, свободный.

14. Chetroiu, R. The concept of economic efficiency in agriculture / R. Chetroiu, I. Calin // Munich Personal RePEc Archive paper \# 55007, 2013, posted 3. http://mpra.ub.uni-muenchen.de/55007/

15. Nagornov, S.A. Puti povysheniya effektivnosti ispol'zovaniya svetlyh nefteproduktov v sel'skom hozyajstve /S.A. Nagornov, A.YU. Kornev, S.V. Romancova // Nauka v central'noj Rossii. - 2020. - № 3(45). - S. 112-121.

\section{Сведения об авторах \\ Принадлежность к организации}

Нагорнов Станислав Александрович - доктор технических наук, профессор, главный научный сотрудник Федерального государственного бюджетного научного учреждения «Всероссийский научно-исследовательский институт использования техники и нефтепродуктов в сельском хозяйстве», Россия, г. Тамбов, e-mail: snagornov@yandex.ru.

Корнев Алексей Юрьевич - кандидат технических наук, заместитель директора по научной работе Федерального государственного бюджетного научного учреждения «Всероссийский научно-исследовательский институт использования техники и нефтепродуктов в сельском хозяйстве», Россия, г. Тамбов, e-mail: viitinlab7@yandex.ru.

Романцова Светлана Валерьевна - кандидат химических наук, доцент Федерального государственного бюджетного образовательного учреждения высшего образования «Тамбовский государственный университет им Г.Р. Державина», Россия, г. Тамбов, e-mail: svromantsova@yandex.ru.

\section{Author credentials}

\section{Affiliations}

Nagornov Stanislav - Full Doctor of Technical sciences, Professor, Chief Researcher of Federal State Budgetary Scientific Institution "All-Russian Research Institute for Use of Machinery and Petroleum Products in Agriculture”, Russia, Tambov, e-mail: snagornov@yandex.ru.

Kornev Aleksey - Candidate of Technical Sciences, Deputy Director for Science of Federal State Budgetary Scientific Institution "All-Russian Research Institute for Use of Machinery and Petroleum Products in Agriculture”, Russia, Tambov, e-mail: viitinlab7@yandex.ru.

Romantsova Svetlana - Candidate of Chemical Sciences, Associate Professor of Federal State Budgetary Educational Institution of Higher Education «Tambov State University named after G.R. Derzhavin», Russia, Tambov, e-mail: svromantsova@yandex.ru.

Поступила в редакцию (Received): 06.07.2020 Принята к публикации (Accepted): 15.08.2020 
УДК 662.75; 004.942

DOI: $10.35887 / 2305-2538-2020-4-98-106$

\title{
ОПТИМАЛЬНОЕ УПРАВЛЕНИЕ ПРОЦЕССОМ ПЕРЕЭТЕРИФИКАЦИИ ЖИРОВ РАСТИТЕЛЬНОГО И ЖИВОТНОГО ПРОИСХОЖДЕНИЯ
}

\author{
${ }^{1}$ Нагорнов Станислав Александрович \\ ${ }^{1}$ Корнев Алексей Юрьевич \\ 1,2 Романцова Светлана Валерьевна \\ ${ }^{I}$ ФГБНУ «Всероссийский научно-исследовательский институт \\ использования техники и нефтепродуктов в сельском хозяйстве» \\ ${ }^{2}$ ФГБОУ ВО «Тамбовский государственный университет им. Г.Р. Державина»
}

\begin{abstract}
Pеферат. Обобщены и проанализированы литературные данные по сущзествуюшим технологиям получения биодизельного топлива. Выявлены достоинства и недостатки технологических процессов. Показаны перспективные направления исследований по улучшению отдельных стадий процесса, проводимых в развитых странах. Установлено, что себестоимость и качество получаемого биодизельного топлива зависит не только от используемого исходного сырья, но и от методов управления соответствующим технологическим процессом. Подчеркнуто, что, несмотря на практическую потребность, в современной научно-технической литературе практически отсутствует информация о методах автоматического управления производственным процессом. Рассмотрены положительные и отрицательные характеристики используемого при получении биодизельного топлива блока узла подачи исходных веществ. Предложен вариант улучшения управления прочессом получения биодизельного топлива за счет его автоматизачии. Разработаны способы перехода $\kappa$ оптимальным режимам работы, позволяюшим повысить эффективность данного производства. Полученные оптимальные режимы работы апробированы на разработанной в ФГБНУ ВНИИТиН технологии получения биодизельного топлива из жиров растительного и животного происхождения. Данная технология позволяет получать биодизельное топливо, соответствующее требованиям международного стандарта EN 14214. Приведены общий вид и разработанная принциииальная схема указанной установки. Установлен вид неравенства, который обуславливает степень конверсии растительных масел в биодизельное топливо не менее 97 \%. Выявлено, что при проведении прочесса получения биодизельного топлива управляющим воздействием служит мощность $N$, затрачиваемая на передвижение обрабатываемой среды через реактор. Обоснован критерий оптимальности $K$, с помощью которого можно перейти к энергоресурсосберегающим режимам эксплуатации оборудования для получения биодизельного топлива.
\end{abstract}

Ключевые слова: биодизельное топливо, реакичи переэтерификачии, установка, технология, оптимизаџия, управление, блоки, программы, процессор, микроконтроллер, матричный экран.

\section{OPTIMAL CONTROL FOR THE PROCESS OF TRANSESTERIFICATION OF VEGETABLE AND ANIMAL FATS}

\author{
${ }^{1}$ Nagornov Stanislav \\ ${ }^{1}$ Kornev Alexey \\ ${ }^{1,2}$ Romantsova Svetlana \\ ${ }^{I}$ FSBSI “All-Russian Research Institute for Use of Machinery and Petroleum Products in Agriculture” \\ ${ }^{2}$ FSBEI HE "Tambov State University named after G.R. Derzhavin”
}

\begin{abstract}
Literature data on existing technologies for producing biodiesel are summarized and analyzed. Advantages and disadvantages of technological processes are revealed. The article shows promising research directions for improving certain stages of the process carried out in developed countries. It is established that the cost and quality of the obtained biodiesel fuel depends not only on the raw materials used, but also on the methods of managing the corresponding technological process. It is emphasized that, despite the practical need, there is practically no information about methods of automatic control of the production process in the modern scientific and technical literature. The positive and negative characteristics of the unit used in the production of biodiesel feedstock feed unit are
\end{abstract}


considered. A variant of improving the management of the process of obtaining biodiesel by automating it is proposed. We have developed ways to switch to optimal operating modes that allow increasing the efficiency of this production. The resulting optimal modes of operation tested on the developed in the center Unitin technology in biodiesel production from fats of vegetable and animal origin. This technology allows us to produce biodiesel that meets the requirements of the international standard EN 14214. The General view and developed schematic diagram of the specified installation are given. The resulting optimal modes of operation tested on the developed in the center Unitin technology in biodiesel production from fats of vegetable and animal origin. This technology allows us to produce biodiesel that meets the requirements of the international standard EN 14214. The General view and developed schematic diagram of the specified installation are given. The type of inequality that determines the degree of conversion of vegetable oils to biodiesel is not less than $97 \%$. The General view and developed schematic diagram of the specified installation are given. The type of inequality that determines the degree of conversion of vegetable oils to biodiesel is not less than $97 \%$. It is revealed that during the process of obtaining biodiesel fuel, the controlling influence is the power $N$ spent on the movement of the treated medium through the reactor. The optimality criterion $K$, which can be used to switch to energysaving modes of operation of equipment for the production of biodiesel, is justified.

Keywords: biodiesel, transesterification reaction, installation, technology, optimization, control, blocks, programs, processor, microcontroller, matrix screen.

Введение. Для решения глобальных экологических и энергетических проблем в качестве моторного топлива все шире применяются возобновляемые источники энергии. Наибольшее распространение получило биодизельное топливо $[1-6]$. Несмотря на то, что реакция переэтерификации, как самый важный процесс его получения, известна на протяжении многих десятилетий, во многих передовых странах до сих пор проводятся исследования и поиск научно обоснованных путей модернизации указанного технологического процесса [7 - 11]. Основное внимание уделяется уточнению кинетики процесса, выбору типа катализатора и наилучшего конструктивного оформления реактора [12]. Наименее изученным остаются вопросы, связанные с автоматизацией и управлением рассматриваемого процесса. Вместе с тем, оптимальное управление процессом обуславливает улучшение качества получаемого биодизельного топлива при уменьшении его себестоимости.

Цель исследований - разработка способов оптимального управления процессом синтеза биотоплива с учетом технологических ограничений, позволяющих повысить эффективность данного производства.

Материалы и методы. При исследовании факторов, обуславливающих эффективность получения биотоплива, использованы информационные методы исследования: аналитические, статистические, сравнительные и информационно-логические методы обработки и анализа исходной информации, методы системного подхода.

Результаты и их обсуждение. В настоящей работе использован комплексный подход, учитывающий взаимозависимость и взаимосвязь параметров отдельных стадий техпроцесса. На основе выявления резервов энергоресурсосбережения предложен один из вариантов совершенствования управлением процессом получения биодизельного топлива, позволяющий перейти к оптимальным режимам работы и повысить эффективность данного производства.

Полученные оптимальные режимы работы апробированы на разработанной в ФГБНУ ВНИИТиН технологии получения биодизельного топлива из отработанных растительных масел. Установка предназначена для получения биодизельного топлива соответствующего требованиям международного стандарта EN 14214. Соответствующие блоки установки (общий вид) показаны на рисунке 1, а принципиальная схема с указанием основных технических характеристик узлов на рисунке 2.

Исходя из вышесказанного, основной стадией процесса получения биотоплива является переэтерификация - взаимодействие триацилглицеринов с метиловым спиртом в присутствии катализатора. Предельным (идеальным) случаем синтеза является условие полного взаимодействия триацилглицеринов со спиртом. Однако на практике это условие невыполнимо. Степень конверсии растительных масел в биодизельное топливо определяется путем определения концентраций диацилглицеринов $\left(C_{1}\right)$, моноацилглицеринов $\left(C_{2}\right)$, метанола $\left(C_{3}\right)$ и глицерина $\left(C_{4}\right)$ на выходе из реактора за время $\left(\tau_{\kappa}\right)$. 


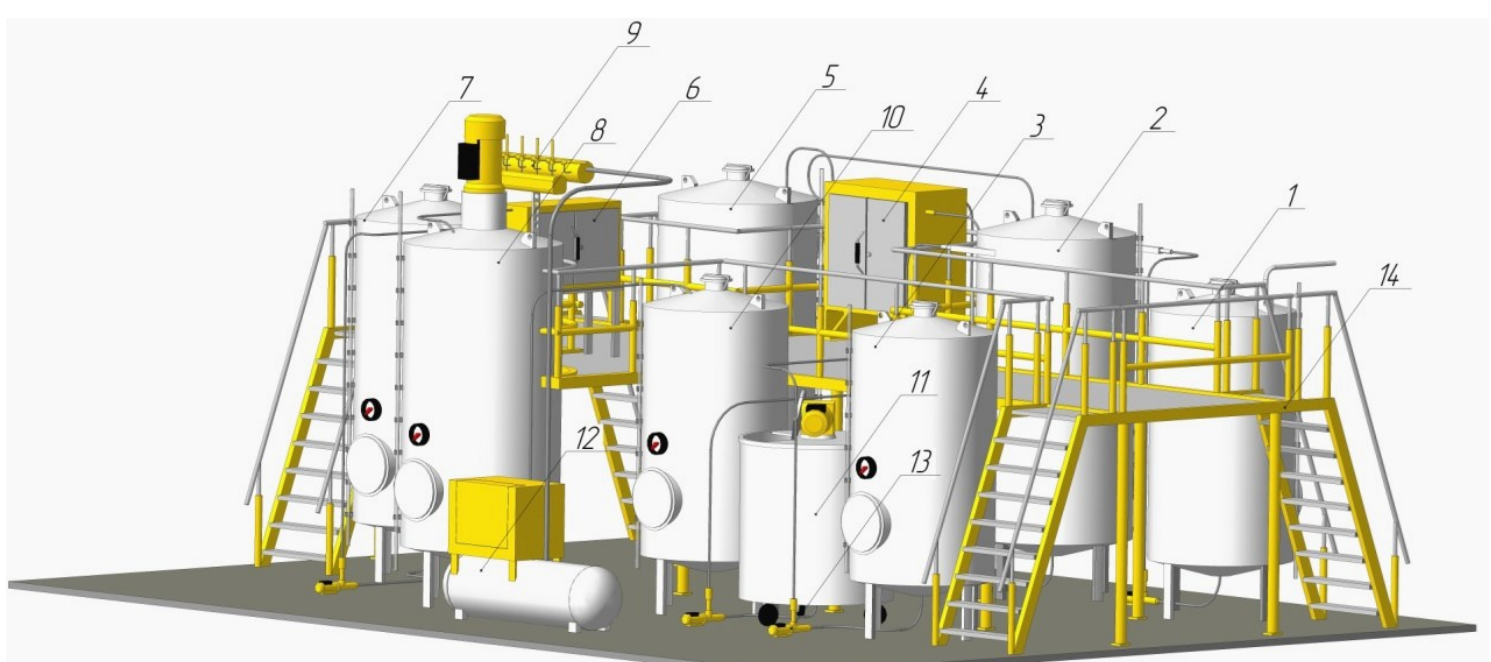

1 - емкость с растительным маслом; 2 - емкость первой стадии перемешивания реагентов;

3 - емкость с метиловым спиртом; 4 - технологический реактор; 5 - резервная емкость;

6 - аппарат предварительной очистки, 7 - емкость для предварительно очищенного биодизеля;

8 - устройство для удаления паров спирта; 9 - устройство для перевода паров в жидкость;

10 - емкость с готовым биодизелем; 11 - устройство для смешивания;

12 - устройство для нагнетания воздуха; 13 - устройство для подачи веществ;

14 - металлоконструкция

Рисунок 1 - 3Д-модель получения биотоплива

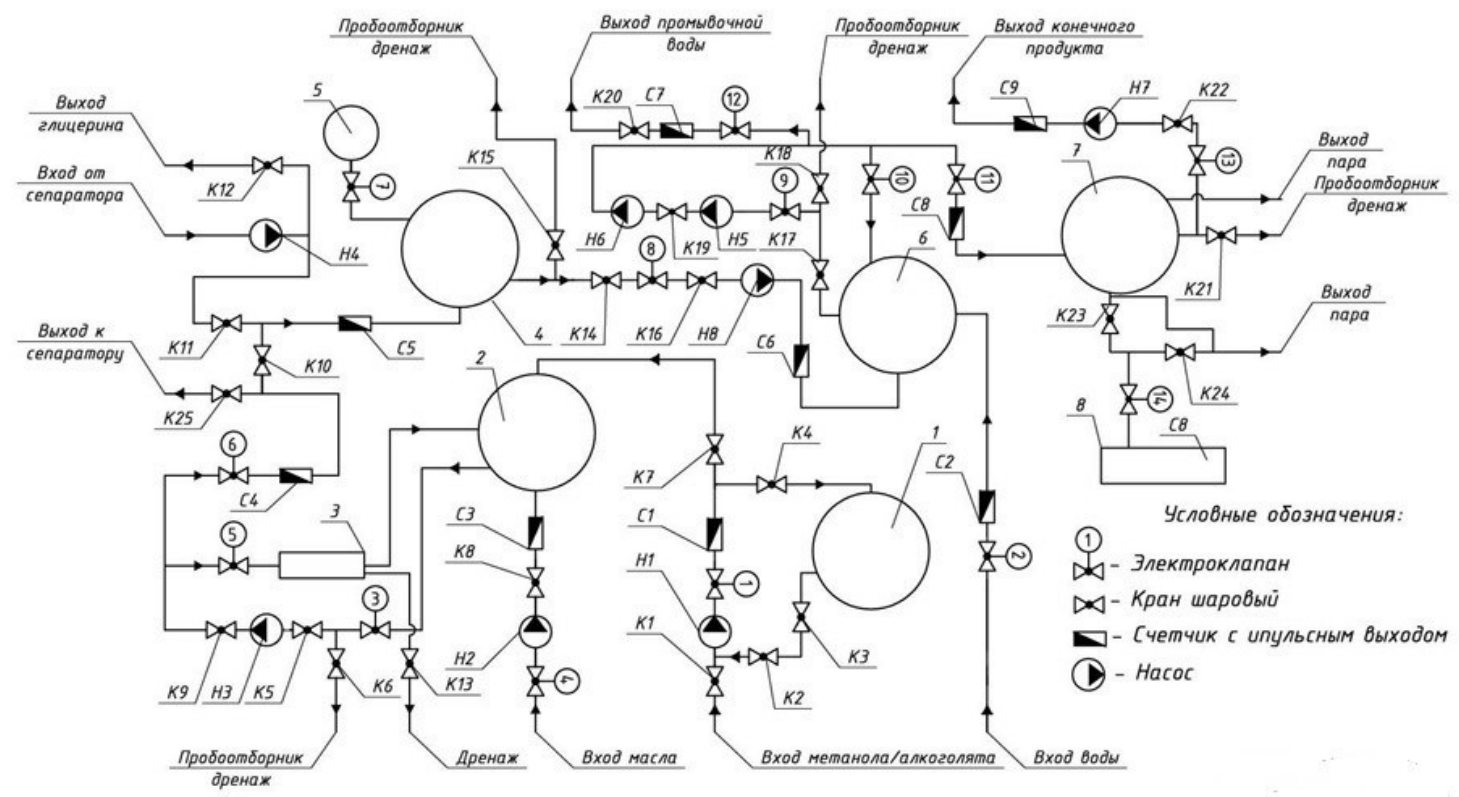

1 - Аппарат с катализатором реакции; 2 - Емкость первой стадии перемешивания;

3 - Аппарат для проведения реакции; 4 - 6 - Емкости для трехстадийной очистки биодизеля; 7 - Аппарат для удаления спирта; 8 - Устройство для нагнетания воздуха;

Н1- Н8 - механизмы перекачки жидких сред;

Рисунок 2 - Блок-схема процесса синтеза биотоплива 
Для того, того чтобы степень конверсии растительных масел в биодизельное топливо была не менее 97 \%, должно соблюдаться следующее неравенство:

$$
C_{1}\left(\tau_{\kappa}\right)+C_{2}\left(\tau_{\kappa}\right)+C_{3}\left(\tau_{\kappa}\right)+C_{4}\left(\tau_{\kappa}\right) \leq 0,03 .
$$

Управляющим воздействием при проведении процесса получения биотоплива является мощность $N$, затрачиваемая на передвижение обрабатываемой среды через реактор. Поскольку качество конечного продукта обусловлено, в частности, временем протекания реакции

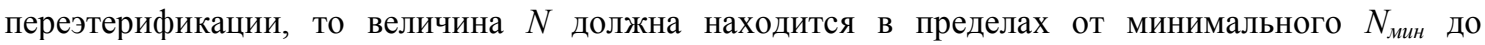
максимального $N_{\text {мах }}$ значения, то есть

$$
N_{\min } \leq N \leq N_{\max }
$$

Для получения конечного продукта высокого качества нужно контролировать давление $p$ на выходе из реактора, которое также должно быть ограничено его предельными значениями, то есть

$$
p_{\min } \leq p \leq p_{\max }
$$

Эффективность решения нашей задачи непосредственно связана с выбором параметра оптимизации, как функции варьируемых режимов техпроцесса, взаимообуславливающего технологические и экономические параметры стадий техпроцесса: минимальную себестоимость заданного объема биотоплива за один цикл работы реактора, как основного показателя экономической эффективности рассматриваемого процесса.

Поскольку затраты на зарплату производственных рабочих, отчисления в социальные фонды, на содержание и эксплуатацию оборудования, цеховые затраты, внепроизводственные расходы при заданных параметрах рассматриваемого техпроцесса практически неизменны (не варьируются), то для нашего случая критерий оптимальности $K_{o c}$ принимает вид

$$
K_{o c}=\frac{C_{v o}+C_{m e t}+C_{e l}}{V_{b i o}},
$$

где $C_{v o}$ - затраты на приобретение отработанного растительного масла, тыс. руб.; $C_{m e t}-$ затраты на приобретение метилового спирта и катализатора, тыс. руб.; $\quad C_{e l}$ - энергозатраты, складывающиеся из затрат на электроэнергию, тыс. руб.; $V_{b i o}$ - месячный выпуск биодизельного топлива, кг.

Требуется определить значения параметров $x_{i}$, при которых отклик системы $y$ принимает значение $y_{\text {min }}$. Целевая функция отклика $y=y\left(x_{1}, x_{2}, V_{b i o}, x_{3}\right)$, тогда задача оптимизации сводится к нахождению $x_{1 o n m}, x_{2 o n m}, V_{b i o}, x_{3 o n m}$, обеспечивающий экстремум функции цели

$$
y\left(x_{\text {lonm }}, x_{2 o n m}, V_{\text {bio }}, x_{3 o n m}\right)=y_{\text {min }} \text {. }
$$

На значения параметров накладываются кроме ограничений (1-3) дополнительные ограничения на выпуск биодизельного топлива

$$
V_{\text {bio }}=m_{\text {mix }} \cdot C_{5}\left(\tau_{k}\right) \text { и } \tau_{k} \leq \tau^{*}
$$

где $m_{\text {mix }}$ - масса исходных веществ; $C_{5}\left(\tau_{k}\right)$ - концентрация метиловых эфиров (биотоплива); $\tau^{*}-$ время окончания технологического процесса.

Разработка оптимального программного управления процессом синтеза биотоплива заключается в контролировании продолжительности процесса и определении времени его окончания $\tau_{\kappa}^{*}$ и функцию управляющих воздействий $u^{*}(\tau), \tau \in\left(0, \tau_{\kappa}\right)$, при которых параметр оптимизации стремится к минимальному значению.

В качестве примера рассмотрим работу блока узла подачи исходных веществ. Работа данного блока одна из самых ответственных во всем цикле получения биодизельного топлива. Именно в этом блоке происходит начальная дозировка исходных веществ и от того насколько точно соблюдены пропорции, зависит напрямую качество конечного продукта.

Для сокращения времени получения конечного продукта и общих энергозатрат установки разработан алгоритм управления (рисунок 3), описание работы которого приведено в таблице 1.

Все параметры процесса фиксируются соответствующими приборами (рисунок 4).

Разработанная оригинальная система автоматизации и диспетчеризации установки для получения биодизельного топлива предназначена для: контроля и управления установкой; регулирования технологических параметров на различных этапах получения биодизельного топлива; обеспечения экономного потребления тепловой и электрической энергии; мониторинга технологических параметров; обработки и хранения значений контролируемых параметров; оповещения дежурного персонала о возникновении нештатных ситуаций. 


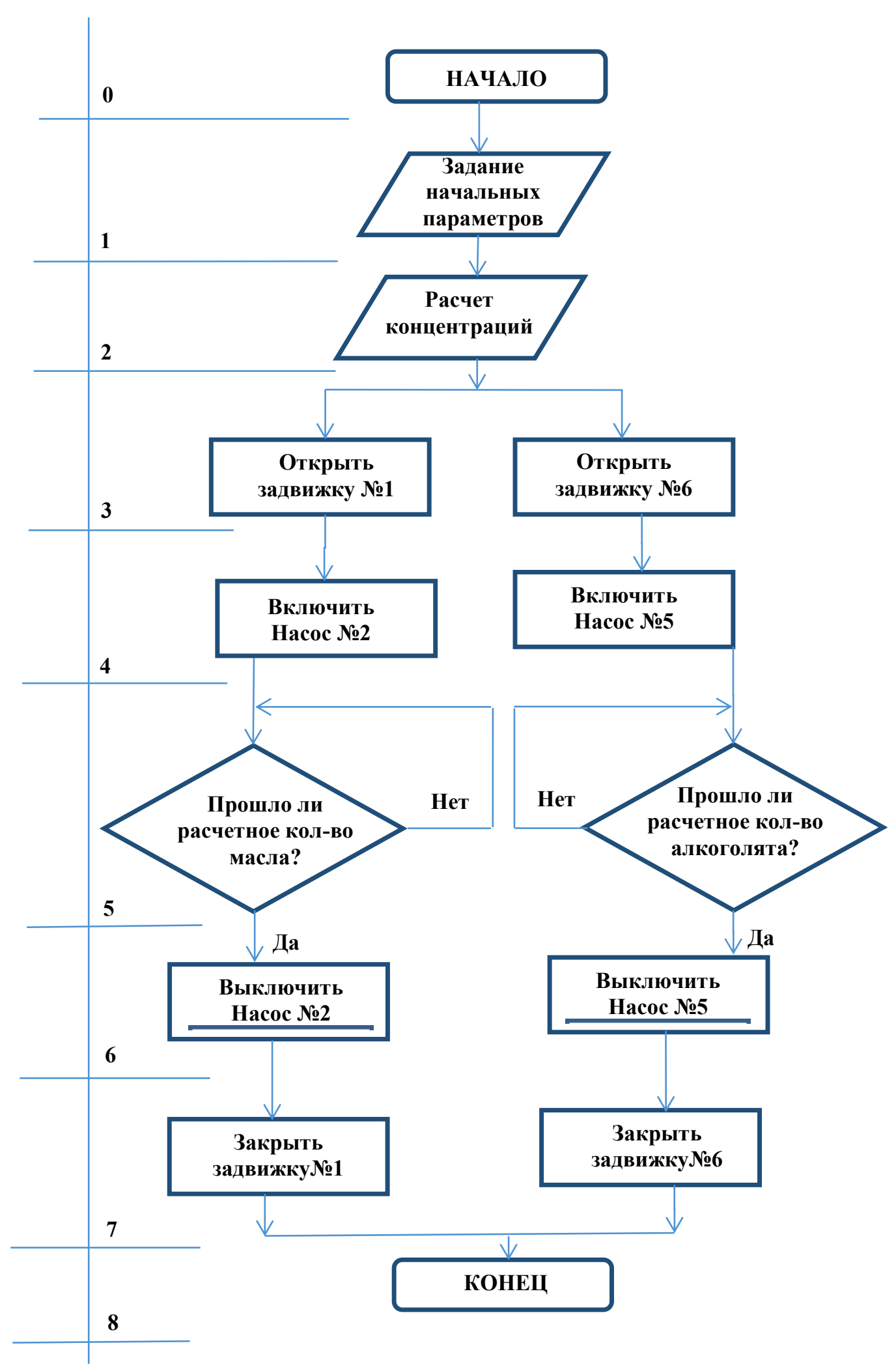

Рисунок 3 - Упрощенный алгоритм управления работой узла подачи исходных веществ 
Таблица 1 - Описание работы управления работой узла подачи исходных веществ (рисунок 3)

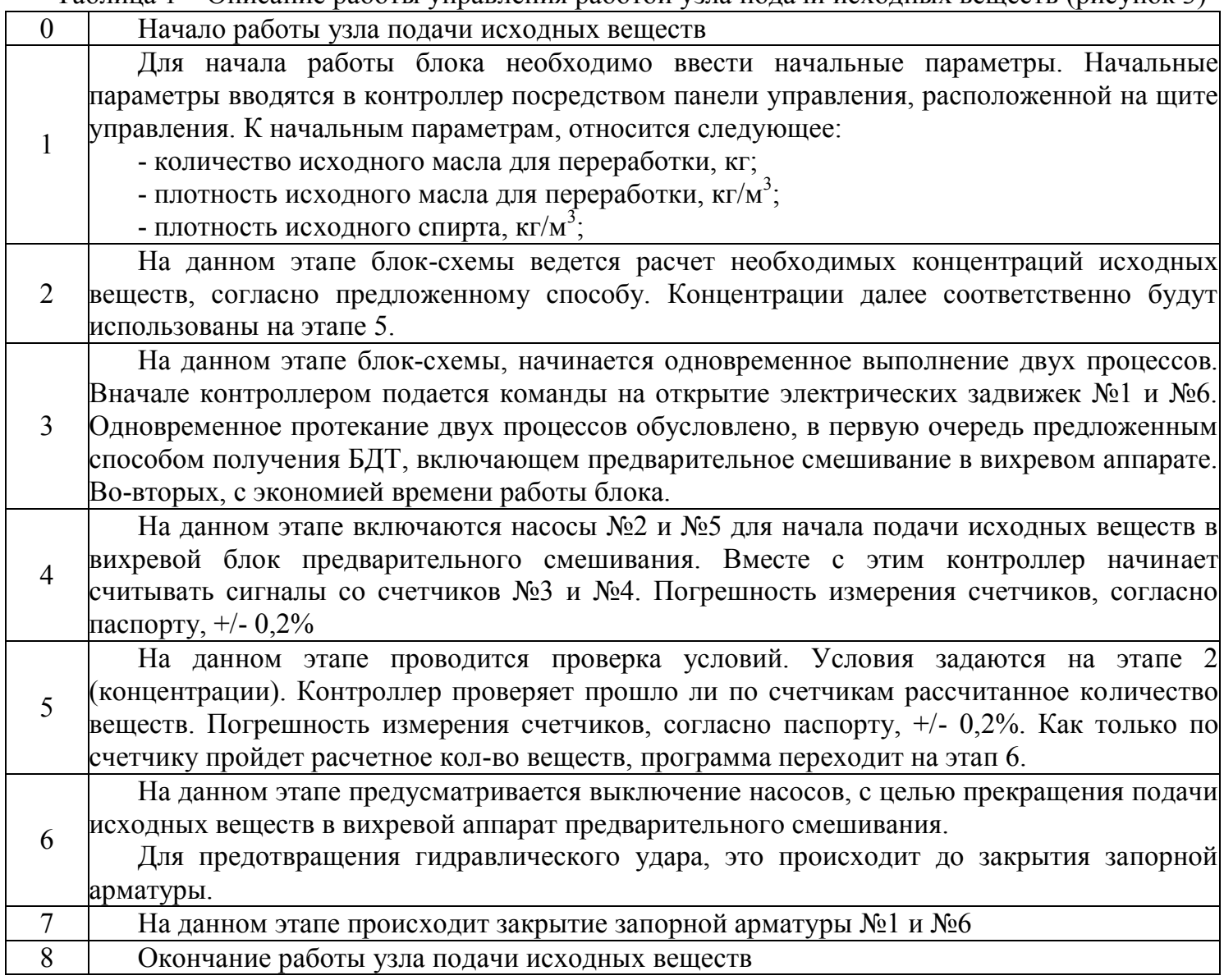

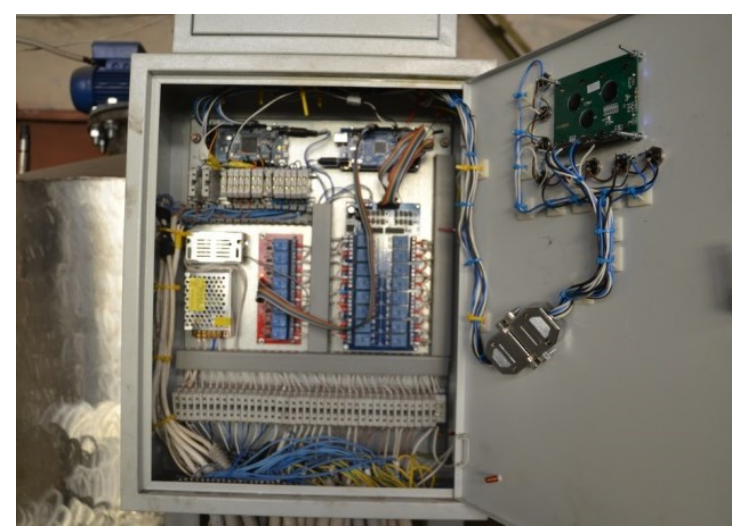

$a$

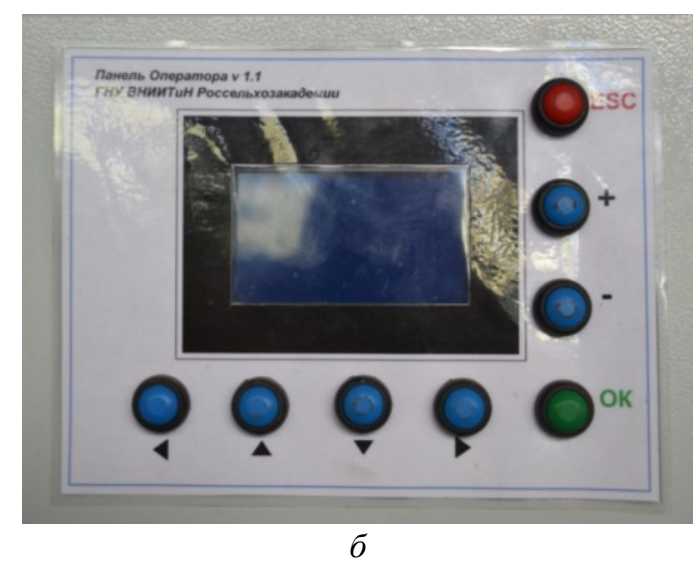

$\sigma$

Рисунок 4 - Общий вид контроллеров, релейных плат (a) и матричного экрана (б)

Система является программно-аппаратным комплексом собственной разработки. Комплекс имеет централизованную, иерархическую многоуровневую структуру, функционирующую в автоматическом режиме. Для сбора, отображения, обработки и хранения результатов измерений, а также управления, выполняемых периферийным оборудованием системы, оборудуется один диспетчерский пункт, оборудованный в помещении операторной. 
Структурно оборудование системы разделено на три уровня.

К оборудованию и программному обеспечению первого уровня относятся: автоматизированное рабочее место (АРМ) оператора; операционная система, под управлением которой работает АРМ системы; специализированное программное обеспечение, обеспечивающее выполнение основных функций системы; средства удаленного управления оборудованием второго уровня; средства связи. Структурно комплекс оборудования и программного обеспечения первого уровня является управляющим для прочих компонентов системы.

К оборудованию второго уровня относятся шкафы диспетчеризации и управления, а также программное обеспечение в составе: средства управления связью с комплексом автоматики установки; средства сбора информации с первичных преобразователей температуры, датчиков давления, расходомеров, дозаторов, датчиков уровня и т.д.; средства управления запорной арматурой и насосными агрегатами. Оборудование второго уровня устанавливается в помещении размещения установки.

К оборудованию третьего уровня относятся измерительные приборы, датчики, сигнализаторы, а также исполнительные устройства - запорная арматура с электроприводом и насосные агрегаты, дозаторы.

В свою очередь шкафы диспетчеризации и управления, являются управляющими устройствами локальной подсистемы, в состав которой входит оборудование установки по получению биодизельного топлива. Подсистема диспетчеризации и управления установкой содержит каналы измерения технологических параметров и позволяет получать следующую информацию: количество (уровень) исходных и конечных компонентов в емкостях; температуру $\left({ }^{\circ} \mathrm{C}\right)$ в выбранных точках системы; давление (кПа) в выбранных точках системы; состояние, в котором находится система (приготовление исходной смеси, предварительное смешивание компонентов и т.д.); пожарная сигнализация; охранная сигнализация; наличие электропитания; работа насосов; работа запорной арматуры; расход электрической энергии и воды.

Также возможно отображение данных (технологических параметров, журнала аварийных сообщений, сведений о количестве полученного конечного продукта и т.д.) в удаленном режиме на экране компьютера, ноутбука, планшетного компьютера, смартфона-коммуникатора при наличии интернет соединения.

Таким образом, разработанная система позволяет автоматизировать процесс получения биодизельного топлива от забора компонентов из исходных емкостей вплоть до заполнения емкостей с конечным продуктом, что в соединении с инновационной технологией получения биодизельного топлива позволит сократить время реакции (более $20 \%$ ), расходы на электрическую энергию (экономия суммарных удельных энергозатрат свыше 10 \%), уменьшить габаритные размеры установки и повысить надежность устойчивости функционирования установки в непрерывном режиме. Установка работает в автоматическом режиме. Загрузка масла составляет 600 кг/ч. Результаты использования разработанного способа оптимального управления приведены в таблице 2. Следует отметить отсутствие некондиционного топлива при оптимальном управлении реакции переэтерификации.

Таблица 2 - Основные преимущества использования оптимального управления

\begin{tabular}{|l|c|c|}
\hline \multicolumn{1}{|c|}{ Показатели } & $\begin{array}{c}\text { По базовому } \\
\text { варианту }\end{array}$ & $\begin{array}{c}\text { При оптимальном } \\
\text { управлении }\end{array}$ \\
\hline Масса полученного биотоплива, кг & 117,3 & 124,5 \\
\hline Количество затраченной мощности, кВт/ч & 3,18 & 2,64 \\
\hline Себестоимость, руб/кг & 5,26 & 4,88 \\
\hline
\end{tabular}

Анализ проведенных исследований показывает, что при найденных оптимальных режимах управления концентрация биотоплива в реакционной смеси достигает не менее 95\%. Давление, при котором реакционную смесь следует перекачивать на следующую стадию процесса необходимо поддерживать в пределах $115 \pm 5$ кПа.

Заключение. Разработанный алгоритм оптимального управления приводит к более полному использованию исходных веществ, увеличивая выход биодизельного топлива до 98 \%. Работа установки в автоматическом режиме предотвращает возможные ошибки и просчеты ручного 
режима, совершаемого оператором. Это приводит к улучшению качества получаемого биотоплива. Широкое использование разработанного в настоящей статье алгоритма оптимального управления позволит снизить себестоимость биодизельного топлива при улучшении его качества в полном соответствии с требованиями соответствующих стандартов.

\section{Список литературы}

1. Нагорнов С.А., Марков В.А., Девянин С.Н. Применение смесевых биотоплив на основе метиловых эфиров растительных масел в транспортных дизелях // Безопасность в техносфере. 2011. - № 6. - С. 26-33.

2. Марков В.А., Девянин С.Н., Нагорнов С.А., Акимов В.С. Биодизельные топлива из различных сырьевых ресурсов // Транспорт на альтернативном топливе. - 2011. - № 3 (21). - С. 25-31.

3. Марков В.А., Девянин С.Н., Нагорнов С.А., Л.И. Быковская. Оптимизация состава многокомпонентных биотоплив для дизелей сельскохозяйственных машин // Наука в центральной России. - 2013. - № 3 . - С. 36-53.

4. Гаврилова В.А., Конькова Н.Г., Нагорнов С.А., Романцова С.В. Рыжик - перспективная масличная культура для производства биодизельного топлива // Агро ХХІ. - 2013. - № 1-3. C. 43-44.

5. Нагорнов С.А., Романцова С.В., Корнев А.Ю., Мещерякова Ю.В. Липиды микроводорослей как сырьё для синтеза биодизельного топлива / В книге: ХХ Менделеевский съезд по общей и прикладной химии. Тезисы докладов в 5 томах. Уральское отделение Российской академии наук. 2016. - С. 465.

6. Ликсутина А.П., Романцова С.В., Корнев А.Ю., Ерохин И.В. Влияние биодизельного топлива на некоторые конструкционные материалы // Инновации в сельском хозяйстве. - 2015. № 2 (12). - С. 130-134.

7. Нагорнов С.А., Дворецкий Д.С., Дворецкий С.И., Ермаков А.А. Моделирование гидродинамики в реакторе с вихревым слоем ферромагнитных частиц при синтезе биотоплива // Вопросы современной науки и практики. Университет им. В.И. Вернадского. - 2010. - № 1012 (31). - С. 359-368.

8. Нагорнов С.А., Романцова С.В., Рязанцева И.А., Бодягина С.В. Интенсификация синтеза биодизельного топлива вращающимся электромагнитным полем //Механизация и электрификация сельского хозяйства. - 2010. - № 5. - С. 8-10.

9. Нагорнов С.А., Корнев А.Ю., Романцова С.В., Ерохин И.В. Инновационная технология получения биодизельного топлива // Сельский механизатор. - 2015. - № 7. - С. 36-37.

10. Дворецкий Д.С., Нагорнов С.А., Ермаков А.А., Неизвестная С.В. Технология получения биодизельного топлива с использованием гетерофазных катализаторов и СВЧ-нагрева // Вопросы современной науки и практики. Университет им. В.И. Вернадского. - 2012. - № S (39). - С. 136-143.

11. Нагорнов С.А., Дворецкий Д.С., Дворецкий С.И., Ермаков А.А. Моделирование процесса метанолиза растительных масел в аппарате вихревого слоя ферромагнитных частиц // Вестник Тамбовского государственного технического университета. - 2010. - Т. 16. - № 4. - С. 944-953.

12. Нагорнов С.А., Романцова С.В., Дворецкий С.И., Таров В.П. Исследование кинетики процесса метанолиза при переработке растительного масла в биотопливо // Вестник Тамбовского государственного технического университета. - 2009. - Т. 15. - № 3. - С. 572-580.

\section{References}

1. Nagornov S.A., Markov V.A., Devjanin S.N. Primenenie smesevyh biotopliv na osnove metilovyh jefirov rastitel'nyh masel v transportnyh dizeljah // Bezopasnost' v tehnosfere. - 2011. - № 6. - S. 26-33.

2. Markov V.A., Devjanin S.N., Nagornov S.A., Akimov V.S. Biodizel'nye topliva iz razlichnyh syr'evyh resursov // Transport na al'ternativnom toplive. - 2011. - № 3 (21). - S. 25-31.

3. Markov V.A., Devjanin S.N., Nagornov S.A., L.I. Bykovskaja. Optimizacija sostava mnogokomponentnyh biotopliv dlja dizelej sel'skohozjajstvennyh mashin // Nauka v central'noj Rossii. 2013. - № 3 . - S. 36-53.

4. Gavrilova V.A., Kon'kova N.G., Nagornov S.A., Romancova S.V. Ryzhik - perspektivnaja maslichnaja kul'tura dlja proizvodstva biodizel'nogo topliva // Agro XXI. - 2013. - № 1-3. - S. 43-44.

5. Nagornov S.A., Romancova S.V., Kornev A.Ju., Meshherjakova Ju.V. Lipidy mikrovodoroslej kak syr'jo dlja sinteza biodizel'nogo topliva / V knige: HH Mendeleevskij s\#ezd po obshhej i prikladnoj himii. Tezisy dokladov v 5 tomah. Ural'skoe otdelenie Rossijskoj akademii nauk. - 2016. - S. 465. 
6. Liksutina A.P., Romancova S.V., Kornev A.Ju., Erohin I.V. Vlijanie biodizel'nogo topliva na nekotorye konstrukcionnye materialy // Innovacii v sel'skom hozjajstve. - 2015. - № 2 (12). - S. 130134.

7. Nagornov S.A., Dvoreckij D.S., Dvoreckij S.I., Ermakov A.A. Modelirovanie gidrodinamiki v reaktore s vihrevym sloem ferromagnitnyh chastic pri sinteze biotopliva // Voprosy sovremennoj nauki i praktiki. Universitet im. V.I. Vernadskogo. - 2010. - № 10-12 (31). - S. 359-368.

8. Nagornov S.A., Romancova S.V., Rjazanceva I.A., Bodjagina S.V. Intensifikacija sinteza biodizel'nogo topliva vrashhajushhimsja jelektromagnitnym polem //Mehanizacija i jelektrifikacija sel'skogo hozjajstva. - 2010. - № 5. - S. 8-10.

9. Nagornov S.A., Kornev A.Ju., Romancova S.V., Erohin I.V. Innovacionnaja tehnologija poluchenija biodizel'nogo topliva // Sel'skij mehanizator. - 2015. - № 7. - S. 36-37.

10. Dvoreckij D.S., Nagornov S.A., Ermakov A.A., Neizvestnaja S.V. Tehnologija poluchenija biodizel'nogo topliva $\mathrm{s}$ ispol'zovaniem geterofaznyh katalizatorov i SVCh-nagreva // Voprosy sovremennoj nauki i praktiki. Universitet im. V.I. Vernadskogo. - 2012. - № S (39). - S. 136-143.

11. Nagornov S.A., Dvoreckij D.S., Dvoreckij S.I., Ermakov A.A. Modelirovanie processa metanoliza rastitel'nyh masel v apparate vihrevogo sloja ferromagnitnyh chastic // Vestnik Tambovskogo gosudarstvennogo tehnicheskogo universiteta. - 2010. - T. 16. - № 4. - S. 944-953.

12. Nagornov S.A., Romancova S.V., Dvoreckij S.I., Tarov V.P. Issledovanie kinetiki processa metanoliza pri pererabotke rastitel'nogo masla $\mathrm{v}$ biotoplivo // Vestnik Tambovskogo gosudarstvennogo tehnicheskogo universiteta. - 2009. - T. 15. - № 3. - S. 572-580.

\section{Сведения об авторах}

\section{Принадлежность к организации}

Нагорнов Станислав Александрович - доктор технических наук, профессор, главный научный сотрудник Федерального государственного бюджетного научного учреждения «Всероссийский научно-исследовательский институт использования техники и нефтепродуктов в сельском хозяйстве», Россия, г. Тамбов, е-mail: snagornov@yandex.ru.

Корнев Алексей Юрьевич - кандидат технических наук, заместитель директора по научной работе Федерального государственного бюджетного научного учреждения «Всероссийский научно-исследовательский институт использования техники и нефтепродуктов в сельском хозяйстве», Россия, г. Тамбов, e-mail: viitinlab7@yandex.ru.

Романцова Светлана Валерьевна - кандидат химических наук, доцент Федерального государственного бюджетного образовательного учреждения высшего образования «Тамбовский государственный университет им Г.Р. Державина», Россия, г. Тамбов, e-mail: svromantsova@yandex.ru.

\section{Author credentials}

\section{Affiliations}

Nagornov Stanislav - Full Doctor of Technical sciences, Professor, Chief Researcher of Federal State Budgetary Scientific Institution "All-Russian Research Institute for Use of Machinery and Petroleum Products in Agriculture", Russia, Tambov, e-mail: snagornov@yandex.ru.

Kornev Aleksey - Candidate of Technical Sciences, Deputy Director for Science of Federal State Budgetary Scientific Institution "All-Russian Research Institute for Use of Machinery and Petroleum Products in Agriculture”, Russia, Tambov, e-mail: viitinlab7@yandex.ru.

Romantsova Svetlana - Candidate of Chemical Sciences, Associate Professor of Federal State Budgetary Educational Institution of Higher Education «Tambov State University named after G.R. Derzhavin», Russia, Tambov, e-mail: svromantsova@yandex.ru. 
Статьи, поступающие в редакцию, рецензируются.

За достоверность сведений, изложенных в статьях, ответственность несут авторы.

Мнение редакции может не совпадать с мнением авторов материалов.

При перепечатке ссылка на журнал обязательна. Материалы публикуются в авторской редакции.

Отпечатано в типографии «Студия печати Галины Золотовой».

Адрес типографии: 392032, Тамбовская область, г. Тамбов, ул. Кленовая, д. 24.

E-mail: studiapechati@bk.ru.

Дата выхода в свет 31.08.2020. Заказ № 29.

Формат 84x108/16. Бумага офсетная. Печать цифровая.

Гарнитура Times. Объем - 11,1 усл. печ. л. Тираж 100 экз. 
